\title{
Hawaiian Volcanoes During 1955
}

By GORDON A. MACDONALD and JERRY P. EATON

GE OLO GICA L S U R VEY B U L L E T I N 1171

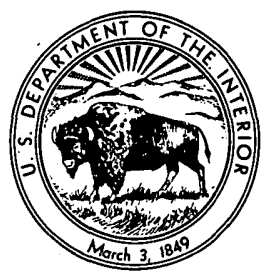




\title{
UNITED STATES DEPARTMENT OF THE INTERIOR
}

\author{
STEWART L. UDALL, Secretary
}

\section{GEOLOGICAL SURVEY}

Thomas B. Nolan, Director

The U.S. Geological Survey Library has cataloged this publication as follows:

\section{Macdonald, Gordon Andrew, 1911-}

Hawaiian volcanoes during 1955 , by Gordon A. Macdonald and Jerry P. Eaton. Washington, U.S. Govt. Print: Off., 1963.

vi, 170 p. illus., maps, diagrs., tables $24 \mathrm{~cm}$. (U.S. Geological Survey. Bulletin 1171)

Part of illustrative matter folded in pocket.

Bibliography : p. 165-167.

1. Volcanoes-Hawaiian Islands. I. Eaton, Jerry Paul, 1926joint author. II. Title. (Series) 


\section{CONTENTS}

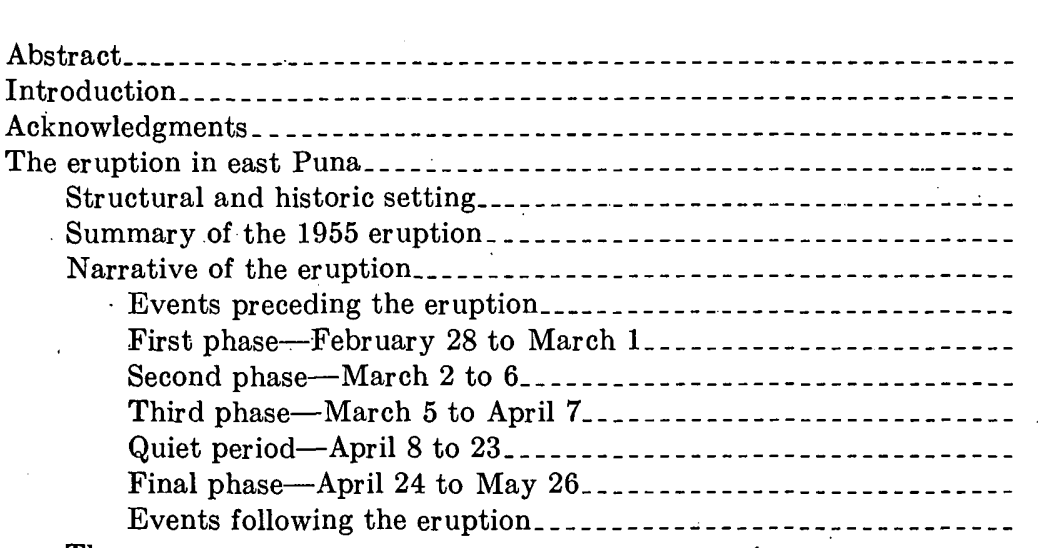

Page

The cones . .

The flows..........

Volume and rate of extrusion of the lava

Composition of the lavas . . . .

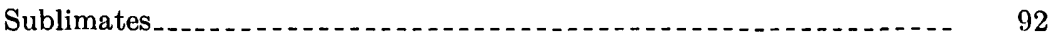

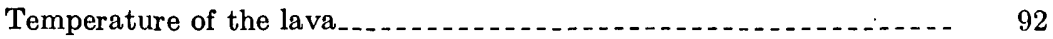

Viscosity of the lavas.

Formation of the pit crater

Ground movements accompanying the eruption . ............ 101

Movements in east Puna............................... 101

Sinking in the Kilauea summit region . . .

Leveling at Kilauea caldera ............................ 111

Earthquakes preceding and accompanying the eruption

Chronological summary . . . . . . . . . . . . 113

Earthquakes of the Kilauea.summit series _. _. _ . . . . . . 118

Earthquakes of the east rift zone series...

Harmonic tremor...

Treatment of earthquake data $\ldots \ldots \ldots \ldots$

Mechanism of the eruption

Losses caused by the eruption

Reoccupation of the area by organisms........ 132

Earthquake traveltimes and crustal structure in Hawaii . . . . . . . . . 133

Hawaiian Volcano. Observatory Summary for 1955 . . . . . . . . . 140

Sesimographs and tiltmeters. . . . .

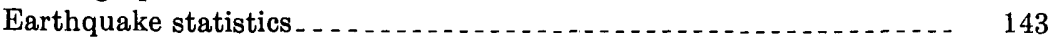

Local earthquakes.

Distant earthquakes. 
Hawaiian Volcano Observatory Summary for 1955-Continued Page

Tilting of the ground........... 151

Crack measurements ....................... 151

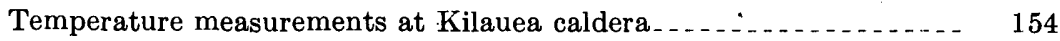

Chemical analyses of Mauna Loa lavas.

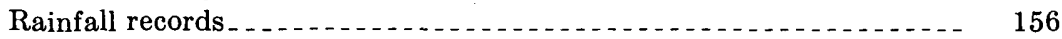

Ages of some prehistoric lavas

Volcanic conditions and earthquakes_._.

Possible volcanic eruption near. Necker. Island _._.

Publications of the Hawaiian Volcano Observatory

Volcano Letter............ 165

Contributions.

Literature cited

Index $\ldots$

\section{ILLUSTRATIONS}

[Plates are in pocket]

Plate 1. Map of southeastern Hawaii, showing the 1955 lava flows.

2. Kilauea summit strain-release index for 1953 through 1955.

3. East Puna strain-release index for 1954 through 1955.

4. Graph showing tilting of the ground surface at the Whitney Laboratory of Seismology during 1955.

5. Graph showing tilting of the ground surface at the Uwekahuna station during 1955.

Figure 1. Map of the island of Hawaii, showing location of places mentioned in text................................ 7

2. Fault scarp forming in road, March 2

3. Margin of aa lava flow, March 3 . .

4. Map of part of east Puna, Hawaii, showing location of vents $\mathrm{Q}$ to $\mathrm{T}$ of the 1955 eruption 30

5. Beginning of formation of new vent, March $13 \ldots \ldots$

6. Fume pouring from fissure, March 13 . . .

7. Lava reaching surface at new vent, March 13_...

8. Later stage in formation of a new vent, March $13 \ldots \ldots$

9. Fume pouring from fissure across highway, March 13_.... 38

10. Lava reaching surface in fissure across highway, March 13__. 38

11. Bulge of lava at fissure in highway, March 13____ 39

12. Spatter cone at vent in highway, March 14_... 39

13. Pit crater formed on March 20

14. Festoons of lava on wall of pit crater $\ldots$

15. Lava fountain at vent $\mathrm{T}$ on March $22 \ldots$

16. Map of part of east Puna, Hawaii, showing location of vents $\mathrm{T}, \mathrm{W}, \mathrm{Y}$, and $\mathrm{Z}$ of the 1955 eruption $\ldots$

17. Aa flow margin on March 28....... 53

18. Lava pouring over sea cliff, March 28....... 54

19. Lava fountain at vent $Y$, March $30 \ldots \ldots$

20. Steaming toe of lava flow and littoral explosion, April 3... 58

21. Pahoehoe tongue near cone T, April 28............. 63 
Figure 22. Pahoehoe tongue at vent $Z$, April 30_........... 64

23. Lava issuing at base of cone $Z_{1}$, May $9 \ldots \ldots$

24. Cascade of lava above Pahoa-Kalapana road, May 17..... 70

25. Aa flow issuing from fracture in older flow unit, May 18_... 72

26. Cone and fountain at vent $Z_{3}$, and lava pond, May $23 \ldots \ldots$

27. Lava river northwest of cone T, May 24_...

28. Graph showing rate of lava discharge during the 1955 eruption

29. Graph showing changes in composition of the lava during the

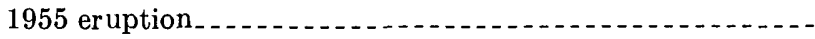

30. Variation diagram of lavas of the 1954 and 1955 eruptions

31. AFM diagram of 1955 lavas . . . .

32. Map of southeastern Hawaii, showing the pattern of the eruptive fissures of the 1955 eruption. . . .

33. Graph showing tilting of the ground at Pahoa and at the Whitney Laboratory of Seismology during the 1955 eruption...

34. Diagram showing movements of the ground in east Puna during the 1955 eruption.

35. Tilt anomaly at the Whitney Laboratory, 1950-55

36-41. Seismograms:

36. Earthquakes of March 27 and August 14

37. Part of Kilauea summit earthquake swarm

37. Part of Kilauea summit earthquake swarm .............

38. Part of Kalalua earthquake swarm . . . .

39. Individual earthquakes.........

40. Harmonic tremor

41. Harmonic tremor from summit area . . . .

42. Graph showing strain-release index, amplitude of volcanic tremor, and ground tilting during the 1955 eruption ......

43-45. Traveltime curves for earthquakes:

43. March 7, 1955

44. April 1, 1955

45. August 14, 1955 $\ldots \ldots$

46. Map of Kilauea caldera and its environs, showing location of Volcano Observatory, bench marks, seismographs, and crack-measuring stations

\section{TABLES}

TABLE 1. Area and volume of 1955 flows and cones

2. Chemical composition of the 1954 and 1955 lavas of Kilauea...-

3. Viscosity of flowing lava during the 1955 eruption.........

4. Elevations of bench marks at Kilauea caldera...........

5. Epochs of the eruption area earthquake swarm and correspondence between seismic data and field evidence.........

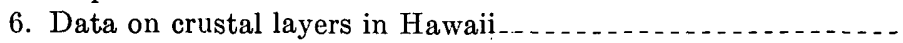

7. Seismographs and tiltmeters operated by the Hawaiian

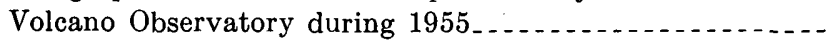


$T_{A B L E}$ 8. Number of earthquakes recorded per week and weekly Page seismicity . . . .

9. Local earthquakes stronger than feeble $\ldots \ldots \ldots \ldots$

10. Distant earthquakes recorded ...

11. Ground tilting at seismograph stations on the rim of Kilauea caldera during 1955 ...

12. Width of cracks at Kilauea during 1955

13. Chemical analyses of lavas of Mauna Loa . .

14. Abundance of trace elements in lavas of the 1949 eruption

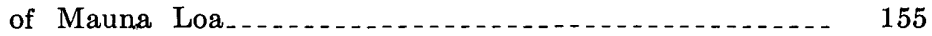

15. Rainfall during 1955 


\title{
HAWAIIAN VOLCANOES DURING 1955
}

\author{
By Gordon A. Macdonald and Jerry P. Eaton
}

\begin{abstract}
The year opened with Hawaiian volcanoes quiescent and Mauna Loa remained so throughout 1955 . The outstanding volcanic event of the year was the eruption of Kilauea volcano, on its east rift zone in the eastern part of the Puna District. The last lava activity on the east rift zone had been in the vicinity of Makaopuhi Crater, in 1923. Not since 1840 had there been activity. in eastern Puna. In 1924, however, a very large number of earthquakes along the east rift zone accompanied the draining of lava from Halemaumau Crater in the caldera and the formation of fault scarps and grabens in eastern Puna. The eastern outbreaks in 1955 closely followed the lines of fissuring and faulting in 1924.

The eruption began on the morning of February 28, near Puu Honuaula, 24.5 miles east-northeast of Kilauea caldera. It was preceded for several months by earthquakes, which gradually increased in number to several hundred a day just before the outbreak. Lava activity at the initial vents continued for only 28 hours and on March 1 was replaced by mild phreatic explosions and clouds of steam.

On March 2 a new series of earthquakes accompanied the formation of fault scarps and opening of fissures 2 miles farther northeast, and at $14^{\mathrm{h}} 15^{\mathrm{m}}$ lava broke out on these fissures. Through the next 2 days the eruptive fissures gradually extended another 2 miles northeastward, to the outskirts of Kapoho village. Lava fountains at the main vents reached a height of at least 800 feet, and flows from them covered approximately 1,100 acres. Activity in that area stopped on March 6.

On March 6 a new series of earthquakes commenced, originating in the area 2 to 12 miles southwest of the initial outbreak, and a new outbreak in that area was predicted. On March 12 lava broke out in that region, and between then and March 27 a series of new vents developed along the rift zone for 4 miles to the southwest. Three lava flows from these vents entered the ocean.

Activity ceased on April 7 but resumed weakly on April 24 and gradually increased until a strong resurgence occurred on May 16. New flows covered much of the area covered by the heads of earlier flows, and some new area, destroying one village. The eruption ended abruptly on May 26.

The volume of erupted material was approximately $141,000,000$ cubic yards. The flows covered an area of about 3,900 acres, of which 1,100 acres was under cultivation. Approximately 6.3 miles of public road and many miles of canefield road were buried, and 21 houses were destroyed. There were no human casualties.
\end{abstract}


The erupted lavas were basalt, becoming slightly more mafic as the eruption progressed. The temperature of lava as it was erupted was approximately $1,100^{\circ}$. C.

The eruption was preceded by swelling of the rift zone, producing a rise of the ground surface of about 1 foot. The several outbreaks of lava were accompanied by sinking of grabens along the crest of the rift zone. The sinking commonly exceeded 1 foot and locally exceeded 5 feet. Stretching of the surface across the areas of eruption resulted in the shifting of known points as much as $\mathbf{5}$ feet in a direction normal to the rift zone.

A gradual tumescence of the volcano commenced in January 1953 and continued until the 1955 outbreak, with virtually no interruption by the brief eruption in the caldera in 1954. During the 1955 eruption there was a sinking of as much as $\mathbf{1 . 4}$ feet in the caldera region. The calculated volume of sinking in the summit region of the volcano had the same order of magnitude as the volume of lava extruded in east Puna. The lava was not, however, simply drained from under the caldera, because the composition of the erupted lavas was appreciably different from that of the lava erupted in the caldera in 1954.

The eruption was accompanied by two distinct selies of earthquakes. The first originated on the east rift zone in and near the eruption area and appears to have been closely related to the actual splitting open of the fissures that led the lava to the surface. The second series originated in and around the caldera, at the summit of the mountain, in response to the subsidence of the summit region that accompanied the eruption farther east. Both series were characterized by very numerous small quakes punctuated at intervals by quakes of moderate size. Between February 23 and March 26 abont 7,500 earthquakes originated on the east rift zone in the eruption area. Between March 6 and April 16 about 11,000 earthquakes originated in the caldera region. The quakes originating in the caldera area were on the average a little smaller than those coming from the east rift zone.

Harmonic tremor of two distinct origins was recorded during the eruption Tremor with a period of 0.8 to 1.0 second was generated in the eruption area during the time lava was being extruded. From March 7 to 19 tremor with a period of 0.3 to 0.5 second appears to have originated at a depth of several kilometers in the vicinity of the caldera. During the first 5 days of this short-period tremor no lava was erupted.

On August 20 a disturbance was reported in the ocean about 60 miles east of Necker Island. This may have been a submarine eruption.

\section{INTRODUCTION}

This report continues the systematic account of conditions at Hawaiian volcanoes begun in earlier reports of this series (Finch and Macdonald, 1951, 1953; Macdonald and Wentworth, 1954; Macdonald, 1955a; Macdonald and Eaton, 1955b, 1957). "The Eruption in East Puna" recounts the detailed observations and analyses of events of the 1955 eruption of Kilauea volcano made by the Observatory staff. "Earthquake Traveltimes and Crustal Structure in Hawaii" reports earthquake traveltime curves for the Hawaiian region based on three earthquakes associated with the 1955 eruption. "Hawaiian Volcano Observatory Summary for 1955 " sets down the systematic observa- 
tions made by the Observatory staff on Hawaiian volcanoes during the year.

The year 1955 began with the Hawaiian volcanoes quiescent at the surface, although moderate seismic activity had originated from beneath. Kilauea for several months. There had been a brief eruption in Kilauea caldera from May 31 to June 3, 1954, emplacing a layer of new. lava 31 feet thick over the floor of Halemaumau crater and spreading a thin flow of pahoehoe over 139 acres of the caldera floor northeast of Halemaumau. This eruption brought only very temporary and slight relaxation in the pressure that had been developing beneath Kilauea since 1952, and by the beginning of 1955 the pressure, as. indicated by the position of the graphs of ground tilting at the northeastern edge of the caldera, was greater than it had been for many years, probably since the period preceding the great subsidence. of the lava column and phreatic explosions in 1924. In the late months of 1954 many earthquakes, both in the caldera region and along the east rift zone, together with the tumescence, indicated growing instability within the volcano. This instability culminated in the most important volcanic event of 1955-an eruption in the eastern part of the Puna District, which lasted from February 28 to May 26. The Puna District is the southeasternmost portion of the island of Hawaii, consisting largely of the broad ridge that extends eastward from Kilauea caldera along the east rift zone of the volcano.

Mauna Loa took no apparent part in the activity. Throughout the year it remained entirely quiescent.

For the first time in modern history, a volcanic event may have occurred in the northwestern part of the Hawaiian chain. Previously, the northwesternmost known activity was the eruption on the southwest flank of Haleakala, the eastern portion of the island of Maui, about 17.50 (Stearns and Macdonald, 1942, p. 102-107). On August 20, 1955 a : possible submarine volcanic eruption was reported east of Necker Island, 500 miles farther northwest.

The : scientific program of the Volcano Observatory continued basically the same as during 1954. A new tiltmeter was installed in the Whitney Laboratory of Seismology, on the northeast rim of Kilauea caldera; and a new experimental electromagnetic seismograph was installed in a new vault near the south edge of the caldera.

The 1955 eruption of Kilauea was unique in several respects. For the first time in history, the complete sequence of formation of new volcanic vents, from the first appearance of cracks in the ground to the completion of cone building, was witnessed by trained scientific observers. Also for the first time, at least in Hawaii, there was witnessed the formation of a pit crater. Unusual features were the irreg- 
ular progression of activity, and the progression upslope along the rift zone, of the formation of new vents. In most eruptions, the fissures open progressively downslope.

\section{ACKNOWLEDGMENTS}

It is impossible to credit here all the numerous persons who aided us during our study of the eruption of Kilauea, but to all of them we extend our sincere thanks. Among those deserving of special mention are :

The personnel of the Hawaii Civil Defense Agency, particularly Deputy Director Peter N. Pakele, Puna Coordinator Myron C. Isherwood, Edward Bento, Richard Chinen, Albert Kudo, Raymond Suefuji, Albert Wilson, and Edward G. Wingate.

The personnel of the Hawaii National Guard, particularly Lt. Col. Michael Roman; Capt. Elroy L. Bohlin, Capt. Ken Chaney, Capt. Joseph Kerns, Lt. D. M. Kinkle, and Lt. J. Y. Tipton, pilots of the observation aircraft; Sgt. Edwin Carreira; Sergeants John Kepoo, M. Kitagawa, T. Nishida, $H$. Yamauchi, and the men of their radio crews.

The personnel of the American National Red Cross, particularly Hawaii Manager John N. Rolfes, Robert Spence, and William Keliipio, who repeatedly brought us food and hot coffee in the field at the most difficult times and places.

The personnel of the Department of Public Instruction, particularly Principal Raymond Torii of Pahoa School.

The personnel of the Olaa Sugar Co., particularly Manager C. E. S. Burns, Jr., Arthur Lyman, and Myron C. Isherwood.

The officers and men of the Hawaii Police Department, particularly Deputy Chief George E. K. Martin, Capt. William Kamau, and Sergeants Claude Bellah, Manuel Gill, Albert Ignacio, and Teruo Morigaki.

The personnel of the Hawaii Fire Department, particularly Chief Robert Kahakua.

Mr. and Mrs. Harold R. Warner, who called our.attention to the disturbances at the Nanawale Ranch before the eruption.

Kiyoshi Takasaki, of the U.S. Geological Survey, who furnished us with notes taken by him on the first two days of the eruption.

County Supervisor Richard Lyman, and County Chairman James Kealoha.

The amateur radio operators who manned the communications office at Civil Defense field headquarters, particularly James Miller and Harold Marques. 
Civilian aircraft pilots William Stearns of the Murray Air Company, Captains Lionel. Machado and Wallace Viean of Hawaiian Airlines; William Myers, and Francis Ruddle; Donald Crozier, manager of Hawaiian Airlines office in Hilo, and the personnel of the Civil Aeronautics Authority at the Hilo Airport control towèr, who repeatedly forwarded messages received from the pilots.

All the above-mentioned persons aided us greatly in many ways during the eruption. The detailed narrative of the eruption, on later pages, is assembled from their reports as well as from our own notes. Particularly, without the aerial observations of the National Guard pilots, the aid of the National Guard radio crews in providing communication, and the vigilance of the Civil Defense wardens, operations: would have been much more difficult and the account of the eruption much less complete.

We wish to thank the Highway Department, Territory of Hawaii, particularly Edward S. Kaaua, Hajime Takata, and Curtis Kamai, for making available to us data from the triangulation and leveling surveys in the region between Pahoa and Kapoho, east Puna, before and after the 1955 eruptions.

Special mention must be made of the aid of Arthur Lyman, field supervisor of the Olaa Sugar Co., and Curtis Kamai, engineer for the Territorial Highway Department. Kamai worked with us almost constantly in the field during the early part of the eruption, keeping flow maps up to date, making independent observations, and aiding in many other ways. He gave particular attention to the construction of barriers. that were built to divert lava flows and to the behavior of the barriers in operation. Arthur Lyman was with us almost constantly, day. and night, throughout the entire eruption, and his phenomenal knowledge of the area and ever-willing counsel aided immensely in keeping track of volcanic events and deciding the courses of action to be taken.

We wish to thank the U.S. Coast and Geodetic Survey for making available records from their seismographs at the Honolulu Magnetic Observatory.

We also wish to thank the persons on the island of Hawaii who have reported the occurrence of earthquakes during the year. Those persons include: Mr. and Mrs. Robert I. Baldwin, Miss Margaret English, Mrs. R. J. H. Farrar; Miss Amy Greenwell; Mrs. Alfred Hansen, Allan P. Johnston, Mrs.'David W. Larsen, Mrs. Juliette Melanphy, Frank Midkiff, Mrs. Troy Osborn, Mrs. Alexander Smith, Miss Nancy R. Wallace, Mr. and Mrs. Harold R. Warner, and Roger Williams.

The staff of Hawaii National Park has continued to be most cooperative and helpful throughout the year. Special thanks are due 
Assistant Superintendents Eugene Barton and Thomas E. Whitcraft, of the Haleakala Section of the Park, and members of their staff, for operating the Haleakala seismograph station.

\section{THE ERUPTION IN EAST PUNA}

\section{STRUCTURAL AND HISTORIC SETTING}

Kilauea is a typical shield volcano, built against the side of the larger shield of Mauna Loa. Within its summit caldera is the collapse crater, Halemaumau, which for a century previous to 1924 was the site of nearly continuous lava-lake activity. Extending both southwestward and eastward from the caldera are rift zones, along which most of the flank eruptions of the volcano have taken place (Stearns and Macdonald, 1946, p. 129, pl. 1). The east rift zone trends southeastward from the caldera for 4.5 miles, then makes an abrupt bend and continues N. $65^{\circ} \mathrm{E}$. to and beyond Cape Kumukahi, the easternmost point of the island of Hawaii (fig. 1). It is marked by numerous open fissures, cinder and spatter cones, and pit craters. More than 70 vents, from which lava poured out onto the surface, can be recognized along the east rift zone, and these represent only the ones that have not yet been buried by later flows. There must be many hundreds more beneath the surface. Extrusion of fluid flows of basaltic lava from vents along the rift zone has resulted in the building of a broad constructional arch, with its crest at the rift zone.

The south side of the rift-zone arch has been steepened by faulting. Although the scarps have been almost wholly buried by later lava flows, their topographic expression remains clear (Stearns and Macdonald, 1946, p. 40, 129-130; Wentworth and Macdonald, 1953, p. 21). One such buried fault scarp lies along the south side of the rift-zone ridge 6 to 12 miles southwest of Cape Kumukahi (Stearns and Macdonald, 1946, pl. 1) and forms unusually steep slopes in the Kamaili and upper Kaueleau areas (pl. 1B).

Flank eruptions of Kilauea have been much less frequent in the short span of historic time in Hawaii than have those of Mauna Loa. Small brief eruptions occurred on the east rift zone just east of the bend in 1922 and 1923 (Jaggar, 1922 ; Finch, 1923). Previous to that, the last had been in 1840, when eruption on the upper part of the east rift zone was followed by a voluminous outpouring of picrite-basalt rich in phenocrysts of olivine from the lower part of the rift zone 8 miles southwest of Cape Kumukahi (Macdonald, 1944, p. 178-181). The head of the principal lava flow of 1840 and of a smaller lava flow 2.5 miles farther southwest are shown on plate 1. About 1790 another lava flow had occurred in the same general area, and about 1750 an- 


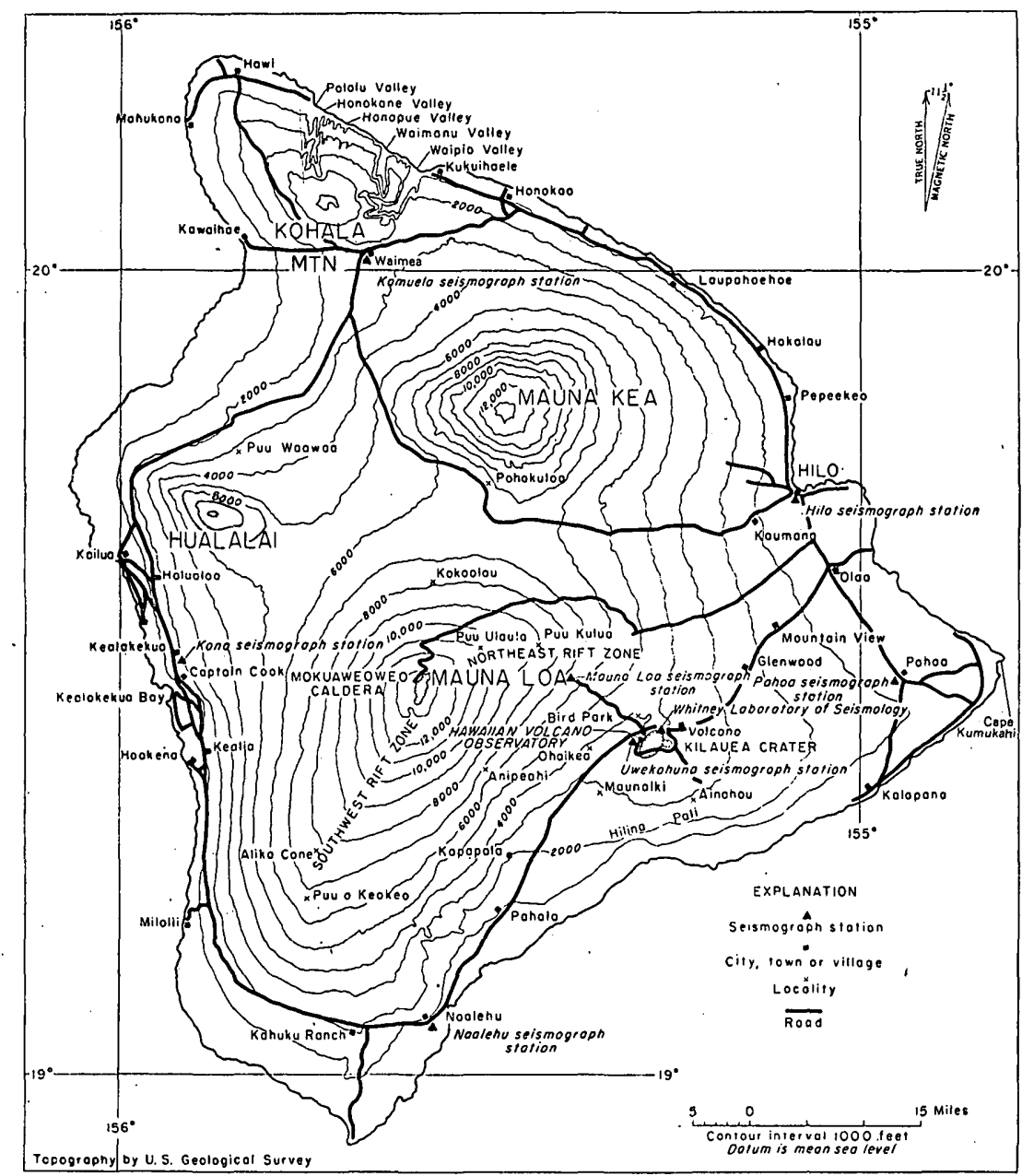

Figure 1.-Map of the island of Hawail, showing the location of the Volcano Observatory, seismograph stations, and localities mentioned in the text.

other had issued somewhere in the vicinity of Heiheiahulu cone, and flowed into the ocean northeast of Kalapana, 14 miles southwest of Cape Kumukahi (Macdonald, 1941). These flows also are tentatively identified on plate 1. Still other, earlier eruptions are mentioned in the unwritten legends and traditions of the Hawaiian people, but their dates are very uncertain. Unquestionably, a large proportion of the area of east Puna must have been inundated with lava during the last thousand years. Thus, eruption on the east rift zone of Kilauea should have been expected, and indeed statements to that effect had been made orally by the late Dr. T. A. Jaggar. Nevertheless, the out- 
breaks of 1955 found nearly all the residents of east Puna unprepared for the event.

In March and April 1924, many earthquakes occurred along the east rift zone. At first the quakes came from centers within 12 miles east of the caldera, but later the foci migrated progressively farther east. The swarm culminated in the area near Kapoho (pl.1) on April 22 and 23 , when the ground was in almost constant motion. Several hundred earthquakes were felt, and many were accompanied by rumblings from the ground. Many open fissures formed along two parallel zones extending S. $65^{\circ} \mathrm{W}$. for about 4.5 miles from just north of Cape Kumukahi. The southern zone passed through Kapoho village and extended just south of Halekamahina hill. The other lay approximately 0.6 mile farther north, along the base of an older fault scarp. The area between the two zones subsided and tilted northward around a hinge line that followed its southern boundary. The greatest displacements were northwest of Kapoho, where a displacement of approximately 12 feet occurred at the foot of the old fault scarp where it crossed the railroad, and near the coast, where a 12-foot subsidence resulted in ocean water drowning the bases of coconut and pandanus trees (Jaggar, 1924; Finch, 1924, fig. 6).

Shortly after the peak of the series of earthquakes there commenced a great subsidence of the molten lava in Halemaumau Crater, in Kilauea caldera, accompanied by violent steam explosions as ground water from the surrounding rocks found entry into the hot conduits beneath the crater. The level of the lava in Halemaumau plunged downward to unknown depths. Collapse of the crater walls more than doubled the diameter of the crater and, after the explosions, left a pit 1,200 feet deep, floored with talus. Differential leveling and records of tiltmeters at the edge of the caldera showed the top of the mountain at the edge of the caldera to have sunk more than 3 feet, and a bench mark at the edge of Halemaumau to have sunk 13 feet (Jaggar, 1947, p. 164-165). No lava, volcanic fume, or new steam vents appeared in east Puna, but nevertheless, Jaggar believed the lowering of the magma level in the caldera to have resulted from intrusion of the magma into the cracked-open east rift, probably with eruption below sea level somewhere beyond Cape Kumukahi.

\section{SUMMARY OF THE 1955 ERUPTION}

The events leading to the 1955 eruption commenced with two strong earthquakes centered in eastern. Puna on March 30, 1954. The quakes came from relatively shallow foci nearly south of Pahoa, between the surface trace of the east rift zone of Kilauea volcano and the south shore of the island. Throughout the rest of the year many earth- 
quakes originated at centers along the east rift zone and in the caldera area. At the same time, tilting of the ground surface in the vicinity of the caldera indicated a swelling of the mountain, apparently caused by an increase of volcanic pressure beneath. The brief eruption in Kilauea caldera, from May 31. to June 3, 1954, had scarcely any effect either on the tilting of the ground surface or the sequence of earthquakes. Both continued uninterrupted through the rest of the year.

In late February 1955, earthquake activity increased greatly and centered in east Puna. By the evening of February 27 it was evident to the senior author that eruption was imminent, and that the outbreak almost certainly would take place in the area about 5 miles eastsoutheast of Pahoa.

The initial outbreak occurred within a few minutes of $8^{\mathrm{h}}$ on February 28. Small lava fountains played along fissures in the ohia forest just north of the road to Pohoiki (A, pl. 1). Two principal fissures, each about 300 feet long, trended N. $65^{\circ}$ E., and were arranged en echelon with the more easterly fissure offset slightly to the north. Farther east-northeast, two other short rows of fountains played from fissures on the south slope of the old cinder cone, Puu Honuaula (B, pl. 1). The lava fountains were 50 to 150 feet high, and from them a rather sluggish lava flow spread southeastward between the base of Puu Honuaula and the road.

At approximately $15^{\mathrm{h}}$ a new group of small fountains developed farther east-northeast, in the saddle between Puu Honuaula and the next hill to the east. (C, pl. 1), and where the fissure crossed a canefield road just west of the fountains the upper edge of a dike of incandescent lava was visible 1 or 2 feet below the ground surface. Bursts of gas from the top of the dike threw showers of glowing lapilli into the air. By $16^{\mathrm{h}} 30^{\mathrm{m}}$ the lava flow from the vents on the south side of Puu Honuaula had blocked the Pahoa-Pohoiki road.

Activity in vent area $\mathrm{C}$ had virtually ceased by $16^{\mathrm{h}} 30^{\mathrm{m}}$, but it resumed about $19^{\mathrm{h}} 30^{\mathrm{m}}$, with the development of a chain of fountains in the area where the glowing dike had been visible earlier. A lava flow from them advanced rapidly southeastward into the canefields.

Conditions continued generally the same, though with fluctuations in the intensity of the lava fountaining, throughout the night and into the morning of March 1. By midmorning activity had ceased at vent area $\mathrm{C}$ but continued in areas $\mathrm{A}$ and B. About $12^{\mathrm{h}} 15^{\mathrm{m}}$ the lava fountains suddenly started to decrease rapidly in size, and by $12^{\mathrm{h}} 20^{\mathrm{m}}$ they were completely dead. Immediately afterward, a great cloud of steam started to roll from vents B and C but not from the vents at A (pl. 1). At most places the emission was rather gentle, and the cloud consisted entirely of white steam. Along the western part of the row of vents 
at $B$, however, the steam roared out violently, carrying with it a cloud of black sand-sized ash. Apparently the rapid withdrawal of molten lava from the upper part of the eruptive conduits had allowed ground water to enter them from the surrounding rocks, and contact of the water with the hot conduit walls resulted in the rapid generation of large volumes of steam. The ash was largely lithic; and apparently resulted from corrosion of the walls of the conduits by the outrushing steam.

The violent escape of steam continued until about $14^{\mathrm{h}} 30^{\mathrm{m}}$, when it started to diminish. Steam poured out of the vents in decreasing amounts throughout the remainder of the afternoon and night. Lava activity at the vents was over, but lava continued to drain from tubes and open channels in the flow until about midnight.

At about $16^{\mathrm{h}}$ on March 1 a brief outbreak of lava occurred in the saddle between two unnamed hills 3,500 feet east-northeast of Puu Honuaula (D, pl. 1). It lasted only a few minutes, and the flow formed in the canefield was less than 50 feet long.

Lack of activity at the vents suggested that the eruption might be over, but the continuation of large numbers of small earthquakes indicated that that was not the case. During the morning of March 2 new cracks appeared in the ground near the Pahoa-Kapoho road, 1.25 miles east-northeast of Puu Honuaula and 0.2 mile southeast of the old cinder cone, Puu Kii. The road was broken by a southeast-facing fault scarp 18 inches high, which continued east-northeastward along the old railroad with displacement as great as 3 feet. We watched fissures and fault scarps develop by a series of slow gradual movements accompanied by sharp small earthquakes of very local origin. By $13^{\mathrm{h}}$ the fissures had spread northeastward to the vicinity of Halekamahina hill, less than a mile from the outskirts of Kapoho village. The fissuring was following closely the zone of fractures formed during the great swarm of earthquakes in the spring of 1924 .

At $14^{\mathrm{h}} 15^{\mathrm{m}}$ lava broke out in the canefield north of the Kapoho-Pahoa road (E, pl. 1), 0.1 mile northeast of the initial fissuring across the road. First a cloud of dense white fume appeared, then after an interval of 2 or 3 minutes clots of incandescent lava started to shoot above the tops of the cane. Within 5 minutes of the first appearance of lava the line of fountains had increased in length to a quarter of a mile, the fountains had grown to a height of 50 feet, and very active flows of pahoehoe were spreading outward at a rate of about 40 feet per minute.

The rest of the afternoon and night was marked by the opening of a series of vents extending from M to L (pl. 1). Activity at most of the vents lasted only from a few minutes to a few hours. 
Vents $\mathrm{M}, \mathrm{J}$, and $\mathrm{E}$ were longer lived than the other vents and became the principal vents of the eruption between March 3 and 10. They lay on fissures arranged en echelon, with each fissure offset to the left in relation to the preceding one. The largest fountain was at vent $\mathrm{E}$, close to the locus of the initial outbreak on March 2. By the early hours of daylight on March 3 this fountain averaged about 200 feet in height, and occasional bursts of cinder reached heights of 350 or 400 feet. The three groups of fountains fed a very active flow of aa. At $6^{\mathrm{h}} 30^{\mathrm{m}}$ on March 3 the principal lobe of this flow was advancing 300 feet per hour over a front 500 feet wide, just south of the PahoaKapoho road. Another, less active lobe lay farther south.

About $19^{\mathrm{h}}$ on March 3 new fissures appeared in the old railroad bed at the west edge of Kapoho, and within a short time had extended through the center of the village itself. Lava fountains broke out in the outskirts of the village $(\mathrm{P}, \mathrm{pl} .1)$ at approximately $21^{\mathrm{h}} 30^{\mathrm{m}}$, but fountain activity was restricted to the westernmost part of the line of fissures, and a low ridge turned the flow of lava northward, away from the main part of the village. Activity at the Kapoho vents was short lived. By $7^{\mathrm{h}} 30^{\mathrm{m}}$ on March 4 lava ejection at the easternmost vent had been replaced by a cloud of steam similar to those at Puu Honuaula on March 1, and by about $10^{\mathrm{h}}$ activity at the Kapoho vents was over.

The lava flow from vents $\mathrm{E}, \mathrm{J}$, and $\mathrm{M}$ crossed the coast road on the evening of March 4. On that day and the next the lava fountain at vent $\mathbf{E}$ reached a height of more than 800 feet. On March 6, however, the fountains rapidly died down. By the morning of March 7 there was no sign of activity at the vents, and the big flow was stagnating without having reached the ocean.

Again it looked briefly as though the eruption might be over. The seismographs indicated otherwise, however. As early as March 5 another series of earthquakes was under way, this time originating in a zone southwest of the Puu Honuaula vents, within a few miles on each side of the road from Pahoa to Kalapana. A new outbreak in that area appeared probable. For nearly a week we waited, while earthquakes occurred as frequently as two per minute for hour after hour, and eruption appeared more and more certain. Finally, on the morning of March 12 cracks opened across the Pahoa-Kalapana road south of the crest of the rift-zone ridge, 3.5 miles south of Pahoa.

On the evening of March 12 lava broke out near Puu Kaliu (Q, pl. 1), 2 miles east of the Pahoa-Kalapana road, and on the morning of March 13 a series of outbreaks occurred just east of the road (R, pl. 1). First, hairline cracks opened in the ground, gradually widen- 
ing to 2 or 3 inches. Then a cloud of white choking sulfur dioxide fume (figs. 5 and 6 ) poured from the crack. This was followed a few minutes later by the ejection of scattered, tiny fragments of redhot lava, and then the appearance at the surface of a small bulb of viscous molten lava (fig. 7). The bulb gradually swelled to a diameter of 1 to 1.5 feet, and started to spread laterally to form a lava flow. From the top of the bulb there developed a fountain of molten lava which gradually built around itself a cone of solidified spatter (fig. 8). The same general sequence was observed at three separate points during the day.

During the afternoon activity spread southwestward across the Pahoa-Kalapana road (figs. 9, 10, and 11), and by the morning of March 14 a spatter cone 30 feet high stood athwart the road (fig. 12).

On March 14' a lava fountain 400 feet high developed about a mile east of the Pahoa-Kalapana road (S, pl. 1). A rapid lava flow from the fountain swept down through Kaueleau and on March 16 entered the ocean, sending up great clouds of steam.

During the afternoon of March 16 a new outbreak (T, pl. 1) occurred south of the Old Iilewa Crater, 1 mile southwest of the scene of the March 13 activity at the Kalapana road. Another outbreak (U, pl. 1) took place 2 miles southwest of the road on March 19. Flows from the latter vents crossed the Pahoa-Kalapana road on the evening of March 19, but the activity of the vents lasted only about a day.

On March 20 activity increased at vent $T$. The lava fountain reached a height of 600 to 750 feet, and flows from it advanced into the Kamaili area. Pumice and Pele's hair fell abundantly in Pahoa, 5 miles away. A cone of pumice, cinder, and welded spatter 1,000 feet across and about 100 feet high was built around the fountain. On the morning of March 21 a tongue of one of the flows from vent $\mathbf{T}$ entered the head of a small valley that led directly to a small plantation camp, known as the Iwasaki Camp. In an effort to keep the flow from reaching the camp, a diversion barrier was hurriedly thrown up by bulldozers. During the afternoon the flow reached the barrier and turned. After advancing along the barrier only about 50 feet, the supply of lava to the flow was cut off and all movement in that tongue stopped.

The next day Robert Yamada, of Hilo, started construction of another series of short barriers to try to divert another part of the flow from his coffee plantation. The behavior of these and other barriers has been discussed elsewhere (Macdonald, 1958).

At $16^{\mathrm{h}} 03^{\mathrm{m}}$ on March 20 a sharp explosion from vent area $\mathrm{R}$, only about 150 feet east of the Pahoa-Kalapana road, threw dark ash 500 feet into the air. Several similar explosions followed within the 
next 2 hours. Air reconnaissance revealed a nearly circular pit with a mouth about 30 feet in diameter and a brightly glowing interior (fig. 13). The walls were overhanging, the diameter of the base of the pit being at least twice that of the mouth. A tongue of pale blue and yellow flame played over the aperture at night, and the temperature of the interior was estimated on the basis of color to be at least $100^{\circ} \mathrm{C}$ hotter than the cores of the lava fountains, presumably because of combustion of volcanic gas in the pit. The edges of the pit caved back rapidly during the next few days, revealing it to be about 135 feet deep and floored with talus from the collapsing rim. The walls were covered with a tapestry of stalactites formed by melting and dripping of the old rocks under the intense heat of the burning gas. This is a small pit crater, similar to those along the Chain of Craters road in Hawaii National Park. The volume of ash ejected by the explosions was very much less than the volume of the crater. Obviously, the crater was formed principally by collapse, probably as the result of withdrawal of molten lava beneath.

At $9^{\mathrm{h}} 55^{\mathrm{m}}$ on March 25 a small outbreak occurred 0.7 mile east of the Pahoa-Kalapana road (V, pl. 1). It was shortlived, however. The lava flow advanced about 350 feet from the vent, and by early afternoon the activity was completely over.

At $20^{\mathrm{h}}$ on March 26 a new outbreak occurred 1,500 feet southwest of vent T. From this new vent $(W$, pl. 1$)$ a rapid aa flow advanced seaward along the south side of the earlier flows, and on March 28 spread across the Yamada coffee plantation and entered the sea. Small explosions caused by sea water coming in contact with the fluid hot lava threw up showers of sand of the sort that forms beaches such as the famous black sand beach of Kalapana. During the evening of March 26 a lava fountain developed at the roaring vent on the northeast side of cone $\mathrm{T}$, and a cinder and spatter cone began to build around it, overlapping the adjacent older cone. The fountains at cone $\mathrm{T}$ became inactive at $2^{\mathrm{h}}$ on March 27 , though occasional roaring gas release continued at a vent on the northeast side of the cone. Early on the morning of March 27 still another vent became active at Y (pl. 1).

Early on March 30 lava activity resumed in vent area $\mathrm{T}$, with fountaining both in the main cone and at the smaller vent on its northeast side. On March 31 a small flow from the latter vent stopped only 2,000 feet from the Iwasaki Camp. A flow that had started from vent $\mathrm{Y}$ on March 28 continued slowly down the south edge of the previous flows and entered the ocean at Kehena on April 2. The lava fountains at vents $\mathrm{T}$ and $\mathrm{Y}$ gradually declined through April 3 to 5 
and became intermittent on April 6. Just after midnight on April 7 all lava activity ceased.

Then for more than 2 weeks there was no activity except for a glowing pit 10 feet across at the northeast base of cone $Y$ and liberation of clouds of white sulfurous fume and steam from other vents. Earthquakes were very few and small. Apparently, however, molten lava continued to stand high in the conduits, for activity resumed quietly and without forewarning.

. On April 24 a.weak lava fountain broke out again in the crater of the main cone at vent $T$. It continued to play for only a few hours. Similar activity again appeared on April 26. For 3 or 4 hours scattered bursts of spatter were thrown to a height of 50 feet, and a small lava flow trickled into the bowl of the crater. The next day a flow of sluggish, dense pahoehoe issued from fissures in lavas of the earlier part of the eruption, about 1,000 feet southeast of the crater of cone $\mathbf{T}$. It advanced 1;500 feet seaward before coming to a stop on April 28.

On April 30 weak fountaining and lava extrusion resumed at the site of the glowing pit at the base of cone Y. From then until May 16 activity at that site gradually increased. Semiexplosive ejections built a cone of loose cinder 75 feet high between cones $\mathrm{W}$ and $\mathrm{Y}$, and close to its northeast base two small spatter cones were built. Lava spread around the vents. Then on May 16 a marked recrudescence of activity took place. The showers of discrete cinders were replaced by. voluminous lava fountaining at the site of one of the two small spatter cones and in the crater of the cinder cone. A large cone of welded spatter $(Z$, pl, 1) rapidly grew around the two fountains, reaching a height of 150 feet and burying the cinder cone, the two small spatter cones, and the remnant of cone W. A broad pool of lava formed east of the cone and spilled southeastward toward the ocean and northeastward into the crater of cone T. At $21^{\mathrm{h}}$ on May 19 lava entered the Iwasaki Camp, destroying about half of the previously emptied buildings.

On May 18 lava had started to spill from the pond northeast of cone $Z$ into the valley northwest of cone $T$. Other small overflows into the valley occurred on subsequent days. Early on the morning of May 24 a great flood of lava broke over the-divide into the head of the valley and quickly formed another broad pond of lava north of cone T. This pond continued to grow through May 24, fed by a spectacular cascade in which the lava attained rates of flow estimated as more than 30 miles per hour. A flow worked northeastward from the pond along a line of old cracks leading toward vent area $R$. Late in the afternoon of May 24 a tongue from this flow spilled southeastward and swept down at great speed across the intersection of the 
Pahoa-Kalapana and Kamaili roads. During the next day a succession of similar small flows invaded the area east of cone $\mathrm{T}$ and shortly after $1^{\text {b }}$ on May 26 destroyed the remnants of the Iwasaki Camp.

During the morning of May 26 vigorous lava discharge and fountaining continued at vent $Z$, but at approximately $11^{\mathrm{h}} 15^{\mathrm{m}}$ on May 26 lava fountain activity ceased very abruptly, and by the morning of May 27 all movement in the flows had stopped. For many months steam and sulfur gases continued to escape from the vents, especially in areas $M, R$, and $T$, but the eruption was ended.

\section{NARRATIVE OF THE ERUPTION}

\section{EVENTS PRECEDING THE ERUPTION}

Throughout most of 1954 the number of earthquakes recorded on the seismograph at Pahoa, in east Puna, averaged a little less than 1 per day. Late in the year the number increased to 2 per day in November, nearly 3 per day in December, 6 per day in January 1955, and 15 per day between February 1 and 23. After that the number increased very rapidly, with approximately 600 being recorded on February 26 and 700 on February 27. Most of the quakes were too small to be felt. However, during the week from February 20 to 27 many quakes were felt in east Puna, particularly 5 miles S. $72^{\circ} \mathrm{E}$. of Pahoa at the Nanawale Ranch, where Mr. and Mrs. Harold Warner reported feeling and hearing a dozen or more daily throughout the week. Many of them resembled explosions, a sharp bump of the ground being accompanied by a sound like that of a muffled quarry blast at a distance of 2 or 3 miles, seemingly to the northwest. Other quakes were preceded by a dull rumbling, also appearing to come from the northwest. At times there was felt a vibration of the ground like that caused by a heavy truck passing on the highway. Vibration of the latter sort was nearly continuous through the afternoon of February 26, interspersed with occasional sharp earthquakes. The ranch dogs were much disturbed, running around excitedly, digging holes in the ground, and snuffling in the holes as though they were in pursuit of some burrowing animal.

We spent most of February 27 at Nanawale Ranch investigating the phenomena. The ranch is situated party on a pahoehoe flow of the 1840 eruption, and the area in which the dogs were digging was above a shallow tube in that lava. No odor of volcanic fume could be detected in the area, which lies almost directly on the prolongation of the eruptive fissure that opened a quarter of a mile away the next morning. No cracks in the ground could be found either at Nanawale Ranch or along the Pahoa-Pohoiki road. 
Thomas Stone, at Koae, 1 mile north of Kapoho, reported feeling sharp earthquakes on an average of about once every 15 minutes through the morning of February 27, the quakes seeming to him to approach from the direction of the ocean (northeast).

From November 1954 through February 1955, press releases from the Hawaiian Volcano Observatory called attention to the growing instability of the volcano. The possibility of eruption without much or any additional warning had been pointed out, but the available evidence was insufficient to justify any definite prediction of imminent eruption. In retrospect, by the evening of February 27 it should have been almost a certainty that the volcano was about to erupt. However, we had strongly in mind the thousands of earthquakes that took place in the same area in 1924, unaccompanied by any visible eruption, and we were too uncertain to make any definite prediction. Actually, the eruption was almost upon us. The outbreak came early the next morning.

\section{FIRST PHASE-FEBRUARY 28 TO MARCH 1}

At approximately $8^{\text {h }}$ on February 28, field workers of the Olaa Sugar Co. and residents of Opihikao village noticed smoke rising from the upper Malama area, just south of Honuaula hill. People in Pahoa noticed the same thing at about $8^{\mathrm{h}} 10^{\mathrm{m}}$. Thus, although the time of the outbreak cannot be placed exactly, it unquestionably was within a few minutes of $8^{\text {h }}$. Volcanic tremor, presumably caused by lava moving upward through the conduits to the surface, began to record on the Pahoa seismograph at $7^{\mathrm{h}} 45^{\mathrm{m}}$. Otherwise, the eruption began quietly. No strong earthquake heralded the appearance of lava at the surface; indeed, eruption was accompanied by an almost complete cessation of the earthquakes that had been so numerous on preceding days.

Investigation of the smoke by Olaa Sugar Co. officials revealed weak lava activity along fissures in the forest between Puu Honuaula and the Pahoa-Pohoiki road (area A, pl. 1). Puu Honuaula is a vegetated cone of lava, spatter, and cinder at the vent of a prehistoric eruption ..on the east rift zone of Kilauea.) The zone of fissures continued 'west-southwestward diagonally across the southern slope of Puu Honuaula and onto the flat land southwest of the hill. At $9^{\mathrm{h}} 40^{\mathrm{m}}$ the Hawaii Police Department reported that a fissure had extended southwestward across the Pahoa-Pohoiki road, about a quarter of a mile east of the Nanawale ranchhouse.

At approximately $10^{\mathrm{h}}$, when we reached the scene of activity, there were two principal fissures, each about 300 feet long, trending N. $65^{\circ}$ E., and arranged en echelon with the more easterly fissure offset 
slightly to the north. Along the more westerly of the fissures (A, pl. 1 ), a roaring gas vent lay approximately 50 feet from the road; a sporadic lava fountain 100 feet from the road threw bursts of spatter to a height of about 25 feet; and the largest fountain of the group, 150 feet from the road, threw a nearly continuous jet of spatter to a height of 50 feet with occasional isolated fragments reaching 100 feet. Other smaller fountains lay just to the east. The eruptive fissure was prolonged westward by a crack extending across the road. The crack in the road was still visibly widening, but no smell of sulphur fume could be detected in it. The second major fissure lay about 250 feet to the northeast of the first. Along it also lava fountains played to a height of 50 to 100 feet, but fume and jungle made it difficult to observe details of the activity. Flows of sluggish pahoehoe were forming around the base of the two fountain chains but had not yet moved far into the forest. At the edge of the flow trees were scorched by the heat of the lava, but they were not actually burned until lava engulfed the trunk. The forest was too wet for the fire to spread away from the flow.

Farther to the northeast, two other short rows of small fountains played from fissures on the south slope of Puu Honuaula (B, pl. 1), and from them a sluggish flow spread slowly southeastward toward the road.

At $11^{\mathrm{h}}$ the fissure across the road had started to fume. The vent 50 feet from the road had become a mildly explosive lava vent, partly buried by viscous lava, and was throwing shreds of incandescent lava to a height of 15 or 20 feet as gas bubbles burst through the sticky liquid. The vent 100 feet from the road had become a steady lava fountain; that 150 feet from the road continued as it had been earlier.

By $11^{\mathrm{h}} 15^{\mathrm{m}}$ the vents at $B$ were nearly inactive, and the lava flow from them was virtually stagnant. At $13^{\mathrm{h}} 40^{\mathrm{m}}$ activity appeared to be entirely restricted to the two principal fissures in area A. At the vent 50 feet from the road, at intervals of 30 seconds to 2 minutes, a 5 by 10 foot area of viscous lava was slowly heaved up into a broad dome, 10 to 15 inches high, which then burst allowing the bubble of gas to escape. Bursting of the bubble left an incandescent red flowerlike crater, 1 to 2 feet across, that quickly turned black on cooling. During the next 30 seconds it gradually closed up as the viscous lava crept into it from the sides. The fountain at the vent 150 feet from the road had built a cone of spatter about 20 feet high and 50 feet across, with a crater 15 feet.across breached toward the west. Within the crater incandescent lava heaved and boiled. Showers of spatter from this vent occasionally reached a height of 100 feet. 
About $15^{\mathrm{h}}$ a new eruptive fissure opened farther east-northeast, in the saddle between Puu Honuaula and the next small hill to the east (area C, pl. 1). At $15^{\mathrm{h}} 20^{\mathrm{m}}$ a line of fountains about 250 feet long was playing to a height of about 50 feet, with occasional bursts reaching 100 feet: Southwestward from them an open fissure 6 to 10 inches wide extended across a canefield road. Within the fissure, 1 or 2 feet below the ground surface, the upper edge of a dike of incandescent lava was visible, and from time to time bursts of gas from the top of the dike threw showers of glowing lapilli into the air. About 1,000 feet east-northeast of the principal fountain chain another isolated group of small fountains was active.

At $16^{\mathrm{h}}$ activity had resumed in vent area $\mathrm{B}$, on the south side of Puu Honuaula, and by $16^{\mathrm{h}} 55^{\mathrm{m}}$ a continuous chain of vigorous lava fountains 200 feet long was throwing a curtain of fire to a constant height of 25 feet, with occasional bursts to a height of 100 feet. Lava from these fountains joined that from the vents in area $\mathrm{A}$ to form a broad flow that advanced southeastward. At $16^{\mathrm{h}} 10^{\mathrm{m}}$ the flow had reached the Pahoa-Pohoiki road, and by $16^{\mathrm{h}} 30^{\mathrm{m}}$ the road was completely blocked.

The fissures were obviously being extended east-northeastward toward the village of Kapoho, 3 miles away. If that continued, Kapoho would be in danger of destruction." Consequently, when.Myron Isherwood, Civil Defense Coordinator for Puna, inquired on the afternoon of February 28 as to what course we thought should be followed at Kapoho, we advised that the village be evacuated. By $17^{\mathrm{h}}$ the evacuation was in progress.

Activity in vent area $\mathrm{C}$ had virtually ceased by $16^{\mathrm{h}} 30^{\mathrm{m}}$, but it resumed at about $19^{\mathrm{h}} 30^{\mathrm{m}}$ with the formation of a chain of lava fountains across the canefield road where the glowing dike had been observed earlier. At $22^{\mathrm{h}} 45^{\mathrm{m}}$ a line of 4 or 5 spattery fountains of gas-rich lava were feeding a pahoehoe flow that advanced at a rate of 5 to 10 feet per minute. near the vents, but slowed to about 100 feet per hour even on a. fairly steep slope 500 feet southeast of the vents.

Conditions remained generally the same, with minor fluctuations in the intensity of lava fountaining, through the rest of the night.

By midmorning on March 1 the two main fountains in vent area $\mathrm{A}$, respectively about 150 and 700 feet from the road, were playing to heights of 50 to 75 feet and had built cones of welded spatter 40 to 50 feet high. Early in the morning the fountain at the vent 50 feet from the road was small and sporadic, but about $11^{\mathrm{h}}$. it increased to a height of about 75 feet, throwing occasional showers of ejecta onto the road. In vent. area $\mathrm{C}$ activity had ceased except for the profuse liberation of bluish sulfurous fumes from the main vents and white 
fumes, mostly steam, from minor vents near the easternmost end of the eruptive fissure.

At about $12^{\mathrm{h}} 15^{\mathrm{m}}$ the lava fountains in vent area $\mathrm{A}$ suddenly started to diminish, and by $12^{\mathrm{b}} 20^{\mathrm{m}}$ they had ceased entirely, and the vents were completely quiet except for low sizzling and rumbling sounds. At $12^{\mathrm{h}} 25^{\mathrm{m}}$ vents in area $\mathrm{C}$ started to blow, the strength of the blast gradually increasing until a column of gas was rushing out with great strength, like a boiler exhaust, carrying with it a shower of small black rock fragments torn from the vent throat. The escaping gas appeared to be wholly steam. At approximately the same time steam discharge started in vent area B also. At most places the steam escaped gently, forming great billowing white clouds, but along the western part of the fissure (opposite the saddle between Puu Honuaula and the smaller hill to the west) the steam roared out violently, carrying with it a cloud of black sand-size ash. As in area C, the ash consisted entirely of fragments torn from the throats of the vents, and when they were examined later the portions of the throats near the surface showed clear evidence of abrasion by the sand blast. We were able to enter the ash cloud and approach within 100 feet of the active vents, but we could detect no taste of salt $(\mathrm{NaCl})$ and only a very slight odor of sulfur gas in the steam. Meanwhile, the vents in area $\mathbf{A}$. remained quiet.

This voluminous discharge of steam undoubtedly resulted from entrance of shallow ground water into the hot conduits through which lava had been rising to the surface. To permit the rapid entrance of ground water into the vents, the molten lava must have receded in the conduits to below ground-water level (a few feet above sea level in that area). Whether the lowering of lava level resulted from withdrawal of magma into and toward the magma chamber, or merely from drainage into newly opened fissures farther east on the rift zone, is not known. However, no noteworthy earthquake activity accompanied or directly preceded the cessation of lava fountaining or the beginning of steam discharge, and the first possibility appears the more probable.

At $13^{\mathrm{h}} 40^{\mathrm{m}}$ the vents in area $\mathrm{C}$ became quiet. In area $\mathrm{B}$ the violent escape of steam continued until about $14^{\mathrm{h}} 30^{\mathrm{m}}$, when it started to diminish. Gradually lessening amounts of steam poured from the vents throughout the remainder of the afternoon and night. Lava activity at the vents in areas $\mathrm{A}, \mathrm{B}$, and $\mathrm{C}$ was over, but molten lava continued to drain from tubes and open channels in the flow until after midnight. At $10^{\mathrm{h}}$ on March 2 only minor amounts of steam with traces of sulfur gas were escaping from the vents, and the flows were completely stagnant. 
At approximately $16^{\mathrm{h}}$ on March 1 a small, brief outbreak of lava occurred in the canefield between two smaller hills 3,500 feet eastnortheast of Puu Honuaula (vent D, pl. 1). It continued for only a few minutes, forming a spatter conelet 5 feet high and a highly gasinflated flow of pahoehoe about 40 feetlong.

\section{SECOND PHASE-MARCH 2 TO 6}

March 2.-On the morning of March 2 the quiet condition at the vents active during the previous 2 days suggested that the eruption might be over, but the resumption of large numbers of small local earthquakes in east Puna indicated that more probably a new phase of the eruption was developing. At about $8^{\mathrm{h}}$ the driver of the school bus noticed a crack approximately 1 inch wide across the PahoaKapoho road 2 miles west-southwest of Kapoho. On his return trip, at about $8^{\mathrm{h}} 30^{\mathrm{m}}$, he found that the crack had widened to approximately 1 foot. At $11^{\text {h }}$ the crack across the Kapoho road was nearly 2 feet wide, trending $\mathrm{N} .65^{\circ} \mathrm{E}$., and fault movement along it had displaced the southeast side downward approximately 18 inches. In the same zone other cracks were forming in a truck road on the route of the former railroad around the south bases of the old cinder cones, Puu Kii and Kaholua o Kahawali. For several hours we (Macdonald and B. J. Loucks) watched the cracks widen and cave in to the accompaniment of nearly constant local earthquakes, many of which undoubtedly originated directly under our feet. Fault scarps as much as 3 feet high also formed (fig. 2), and it is noteworthy that the fault displacement was slow and gradual. We saw no sudden offsets. At first the movement produced a low monoclinal flexure across the road, but as displacement continued the monoclines were broken and replaced by fault scarps. At about $13^{\text {h }}$ Richard Lyman reported the formation of similar cracks in the roadbed near Halekamahina hill, 0.75 mile farther east-northeast.

It was clear that developments were following closely the pattern of 1924 (p. 8), and because the cracking had extended directly through Kapoho village that year it appeared probable that it would do so again. Because the earthquakes of 1924 had not been accompanied by lava extrusion, at least above sea level, it was not certain that there would be further lava outbreaks in 19555 . However, further eruption appeared very probable, and it was suggested that Olaa Sugar Co. fieldworkers in the area southeast of the zone of fissuring be moved to other parts of the plantation. This suggestion was followed, and the evacuation of Kapoho village, already largely accomplished, was speeded up. 


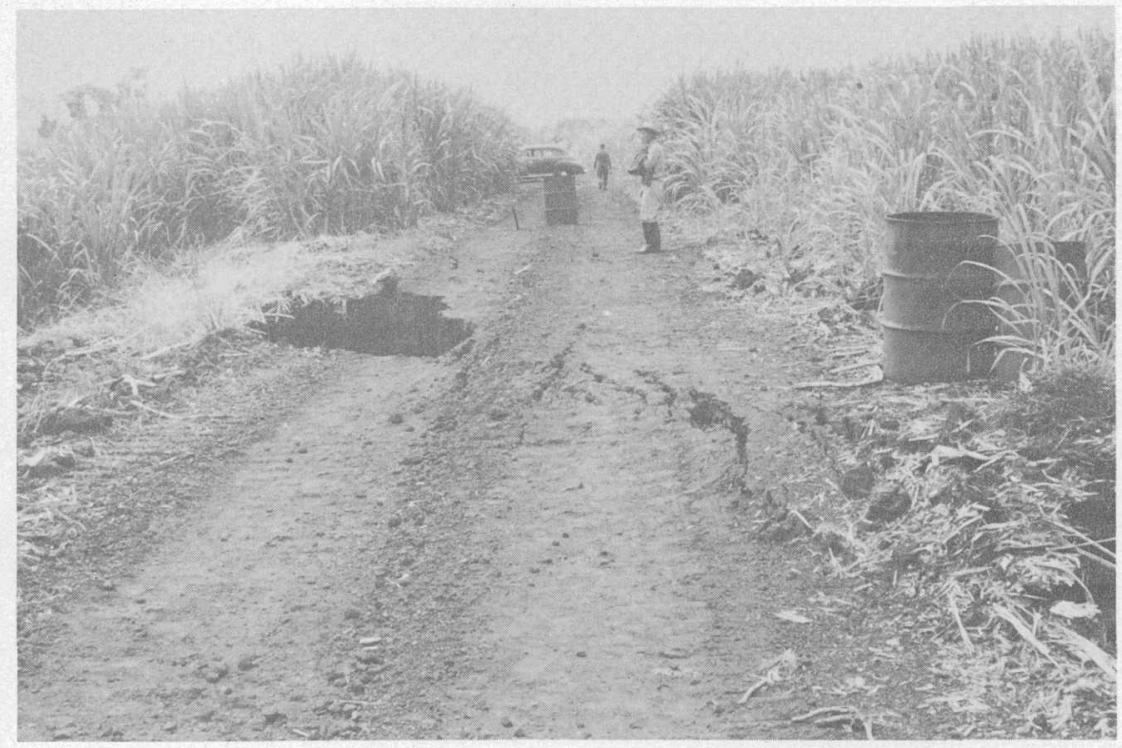

Frgure 2. - Fault scarp forming across a road near vent $\mathrm{E}$ (pl. 1), at about $13^{\text {h }}$ on March 2, 1955. On the right side of the road the scarp is still a monoclinal flexure, just starting to fracture; on the left side the monocline has broken to form a fault scarp.

At $14^{\mathrm{h}} 15^{\mathrm{m}}$ lava fountains broke out in the canefield north of the Kapoho-Pahoa road (E, pl. 1), 0.1 mile northeast of the point where the first fissure had formed across the road, and only about 250 feet from where we were watching the formation of fissures along the old railroad. First a cloud of dense white fume rose from the cane, then after an interval of 2 or 3 minutes clots of incandescent lava started to shoot above the tops of the cane stalks (which were about 5 feet high). The initial line of fountains was only about 30 feet long, but within about 5 minutes of the first appearance of lava the line of fountains had lengthened (mostly downslope) to about 1,000 feet, the fountains had grown to a height of 50 feet, and very active flows of pahoehoe were spreading outward at a rate of about 40 feet per minute. By $15^{\mathrm{h}}$ the flow had blocked the Kapoho-Pahoa road. The lava of this outbreak was very much more fluid than that of the earlier outbreaks at vents $\mathrm{A}$ to $\mathrm{C}$ had been.

The rest of the afternoon and night was characterized by a great proliferation of vents and variation of activity from vent to vent. The latter is unusual in Hawaiian eruptions and therefore worth recording in detail, as is also the sporadic outbreak of new vents both up and downslope from the point of initial outbreak. 
At approximately $16^{\text {h }}$ the erupting part of the fissure again lengthened downhill ( $F$, pl. 1), increasing the total length of the fountain chain to.half a. mile. The fountains remained small, generally reaching heights of 10 to 50 feet, with occasional bursts as high as 100 feet. Very fluid pahoehoe continued to spread around the vents. At $17^{\mathrm{b}}$ there were three principal fingers of the flow, extending approximately 1,000 feet east of the vents.

Through the late afternoon fissuring had been progressing northeastward from vent area F, the gradnal extension of the fissure being marked by the appearance of new clouds of dense pale-brown fume. The breaking was accompanied by many earthquakes, one large enough to be felt occurring on the average about once in 5 minutes. At $19^{\mathrm{h}} 25^{\mathrm{m}}$ a shower of incandescent cinders was thrown from the fissure at a point on the south slope of Halekamahina hill (G, pl. 1). By $19^{\mathrm{h}} 30^{\mathrm{m}}$ this new vent was about 100 feet long and was ejecting showers of cinder to a height of 50 feet. No true fountain ${ }^{1}$ of liquid lava was present. Pale-blue flames as much as 20 feet high flickered along neighboring parts of the fissure. The vent was short lived and by $19^{\mathrm{h}} 35^{\mathrm{m}}$ incandescent lava was no longer being ejected, though flames and dense fume were still issuing from it. At $19^{\mathrm{h}} 45^{\mathrm{m}}$ flames were still present, but the amount of fume was decreasing. Loud "chugging" noises were audible, apparently coming from this vent.

At approximately $19^{\mathrm{h}} 45^{\mathrm{m}}$ showers of cinder appeared at another vent $(\mathrm{H}, \mathrm{pl} .1)$ on the same line of fissuring, about 500 feet northeast of vent G. At $20^{\mathrm{h}} 15^{\mathrm{m}}$ a small lava flow was issuing from this vent, but by $20^{\mathrm{h}} 28^{\mathrm{m}}$ the vent was inactive.

A.t $20^{\mathrm{h}}$ a new line of fountains broke out at I ( pl. 1), between Halekamahina hill and the initial vents near Puu Kii. At $20^{\mathrm{h}} 08^{\mathrm{m}}$ the line of fountains was 300 feet long; and showers of cinder were being thrown 75 to 100 feet into the air. A very fluid lava flow from the new vent was advancing eastward north of the older flow from vents E and F. Loud hissing and chugging sounds issued from the vent, which continued to be vigorously active for about 2 hours.

At $20^{\mathrm{h}} 20^{\mathrm{m}}$ vent $\mathbf{E}$ increased in activity. The main body of the fountains grew to a height of 40 to 50 feet, and pumice bombs were thrown

\footnotetext{
1 True lava fountains are considered to be those containing a virtually continuous; or solid, core of molten rock,'in contrast to showers or sprays of discrete ejecta. True lava fountains are largely or entirely restricted to Hawailan-type activity. Strombolian-type activity, which is more characteristic of most continental volcanoes, generally produces showers of discrete particles rather than true fountains. Unless otherwise stated, in reporting heights of lava fountains the level referred to is that of the top of the continuous core. The continuous core is surrounded by a spray of discrete particles ranging in condition from incandescent liauld to nonincandescent solid, but this spray, which may reach heights more than twice that of the continuous core, is ignored in measuring the height of the fountain. Commonly, in big gas-rich fountains a cloud of dark, nonincandescent pumice and Pele's hair continues to rise and blow away beyond the top of the jet.
} 
to a height of 300 feet. By $21^{\text {h }}$, however, the fountains were again decreasing in size.

About $21^{\mathrm{h}}$ a new group of vents ( $\mathrm{J}$, pl. 1) opened southwest of Puu Kii, just south of the Kapoho-Pahoa road. This event was wrongly identified in an earlier report (Macdonald and Eaton, 1955a, p. 4) as the opening of the vents on Namba's hill (M, pl. 1) ; restudy of the data indicates that the outbreak on Namba's hill came later. The new fissure was slightly offset en echleon to the one at vent $\mathrm{E}$. At $23^{\mathrm{h}} 30^{\mathrm{m}}$ the fountains at $\mathrm{E}$ and $\mathrm{J}$ were still active, but all of the other vents were inactive. A very active lava flow from vents $E$ and $J$ was advancing eastward south of the Kapoho-Pahoa road.

Near the edges of the advancing flows there commonly were observed pale-blue flames similar in color and smell to the flame of an ordinary gas stove. At a few places the flames rose from the lava at the edge of the flow itself, but more commonly they rose from the soil as much as 6 feet from the edge of the flow. The ground at the base of the flames was not very hot, and the flames could easily be slapped out with the hand, but generally they quickly reignited. The burning gas was probably hydrocarbon gas derived by destructive distillation of vegetation and vegetable matter in the soil buried by the flow. Doubtless the gas moved outward from the flow through open- ings in the soil or underlying rocks, and when it escaped at the surface it was ignited by embers blown from burning vegetation.

March 3.-At $0^{\mathrm{h}} 35^{\mathrm{m}}$ a new row of lava fountains 500 feet long broke out on the lower southeast slope of Halekamahina hill ( $\mathbf{K}, \mathrm{pl} .1)$, and a flood of very fluid pahoehoe lava was poured out. For a short time the fountains reached a height of 200 feet. At $1^{\mathrm{h}} 30^{\mathrm{m}}$ the westernmost 100 feet of the fissure ceased to be active, but almost immediately a new segment of the fissure a little farther west became active. Vent $\mathrm{I}$ had again become mildly active, and vents $\mathrm{E}$ and $\mathrm{J}$ continued their mild activity. By $2^{\mathrm{h}}$ lava outflow and true fountaining at vent $\mathrm{K}$ had nearly ceased, but showers of cinder were still being expelled to a height of 250 to 300 feet along the western and central parts of the fissure. At $2^{\mathrm{h}} 10^{\mathrm{m}}$ activity along the western and central parts of the fissure of vent $K$ had ceased entirely, but at the east end of the fissure cinders were being thrown to a height possibly as great as 500 feet. Activity at vent $\mathrm{E}$ had increased somewhat.

At $2^{\mathrm{h}} 25^{\mathrm{m}}$ only very weak spattering continued at the east end of the fissure of vent $K$, but weak cinder ejection had resumed at vent $G$, and mild activity continued at vents $\mathrm{E}, \mathrm{J}$, and I. By $2^{\mathrm{h}} 30^{\mathrm{m}}$ all the vents active on the afternoon and evening of March 2, except vent $\mathrm{K}$, were becoming reactivated, with almost continuous showers 
of cinder. A very dense column of ash started to rise at vent $\mathrm{E}$, but in the poor illumination its exact nature could not be determined.

At $2^{\mathrm{h}} 35^{\mathrm{m}}$ roaring gas release was taking place at the vents in area $\mathrm{K}^{\circ}$. Pale-blue and yellow flames as much as 10 feet long jetted out at various angles from the vents. Alternating increases and decreases of gas pressure affected the whole length of the fissure simultaneously, causing the flames and the noise to alternately increase and subside.

At $2^{\mathrm{h}} 41^{\mathrm{m}}$ a new outbreak occurred at $\mathrm{L}$ (pl. 1.), east of the $K$ vent area, and only half a mile from the outskirts of Kapoho. Within 5 minutes of the first outbreak, cinder was being thrown to a height of 500 feet. By $3^{\mathrm{h}} 25^{\mathrm{m}}$ activity had decreased markedly.

At $3^{\text {h }}$ the ash cloud at vent $\mathrm{E}$ appeared very dense, with slightly convoluting margins. From a distance of 0.7 mile, at night, in the illumination of the lava fountains, it resembled the clouds of ash-laden steam formed at vents $\mathrm{B}$ and $\mathrm{C}$ on March 1. Later search revealed vitric ash as well as very abundant pumice in the area to the lee of the cloud. It appears probable that involvement of ground water produced a minor phreatomagmatic eruption. However, the adjacent lava fountains remained strong, and a vigorous outflow of lava continued. The fountain just west of the base of the cloud, in vent area $\mathrm{E}$, had grown to large size and was throwing showers of incandescent pumice to a height of at least 500 feet.

At $3^{\text {h }} 25^{\mathrm{m}}$ a new line of vents opened on the side of Namba's hill (M, pl. 1), half a mile southwest of vent area E. Lava from these vents joined that from vents $E$ and $J$ to augment a big pahoehoe flow moving eastward south of the road.

At $4^{\mathrm{h}} 10^{\mathrm{m}}$ all of the vents between $\mathrm{E}$ and $\mathrm{L}$ had become inactive, although jets of burning gas were present at many places. At $4^{\mathrm{h}} 25^{\mathrm{m}}$ vent $L$ also became inactive.

At $5^{\mathrm{h}} 10^{\mathrm{m}}$. still another new vent came into existence at $\mathrm{N}$ (pl. 1). For half an hour it was in a stage of vigorous explosion, throwing showers of incandescent cinder to heights of 200 to 300 feet with loud booming noises. Very little lava was extruded, however, and by $6^{\mathrm{h}}$ the vent was nearly dead.

At $6^{\mathrm{h}} 30^{\mathrm{m}}$ the lava flow south of the road had changed into aa, and a very active flow front, 10 feet high and about 500 feet.wide, was advancing about 300 feet per hour 1,500 feet southeast of vent $\mathrm{E}$. This flow was fed jointly by lava fountains at vents $E, J$, and M. All other flows from vents farther east had become stagnant. The ash cloud at vent $\mathrm{E}$ had disappeared. At $9^{\mathrm{h}} 30^{\mathrm{m}}$ conditions continued about the same. The fountain at vent $\mathrm{E}$ had a core of molten lava about 200 feet high and was throwing scattered bursts of spatter and abundant 
pumice to heights of 350 to 400 feet. The fountains at vents $J$ and $\mathrm{M}$ were smaller, reaching heights of 50 to 100 feet.

At $12^{\mathrm{h}} 20^{\mathrm{m}}$ the front of the lava flow reached a craterlike depression on an old fissure (the so-called Malama Crack), about 3,000 feet eastsoutheast of vent E. Pouring into the depression, it formed a lava fall about 50 feet high, at the base of which it reformed into a typical aa flow that continued to move seaward along the bottom of the fissure. Eventually the depression (about 50 feet deep, 80 feet wide, and several hundred feet long before the eruption) filled completely.

At $14^{\mathrm{h}} 10^{\mathrm{m}}$ a small fountain reappeared in vent area $\mathrm{F}$ and for a couple of hours sent a small flow of lava eastward north of the main flow. At $14^{\mathrm{h}} 45^{\mathrm{m}}$ activity in vent areas $\mathrm{E}, \mathrm{J}$, and $\mathrm{M}$ increased markedly, the big fountain at $\mathbf{E}$ consistently reaching heights of 300 to 400 feet.

Throughout the day the lava flow continued to advance eastward south of the road (fig. 3). At $18^{\mathrm{h}}$ the front of the main lava flow reached a low divide approximately 1 mile east of vent $\mathrm{E}$ and about the same distance southwest of Kapoho village. It was feared that if the flow overtopped the divide part of it would advance northeastward to the west of Kapoho cone and destroy the village. Along the top of the divide lay an old railroad embankment, about 10 feet high, that had been converted into a roadbed for cane haulage. By $19^{\mathrm{h}}$ the lava had filled the space west of the embankment and was starting to pile up above it. A few minutes later we received word that new cracks were opening in Kapoho, and we were forced to abandon the area at

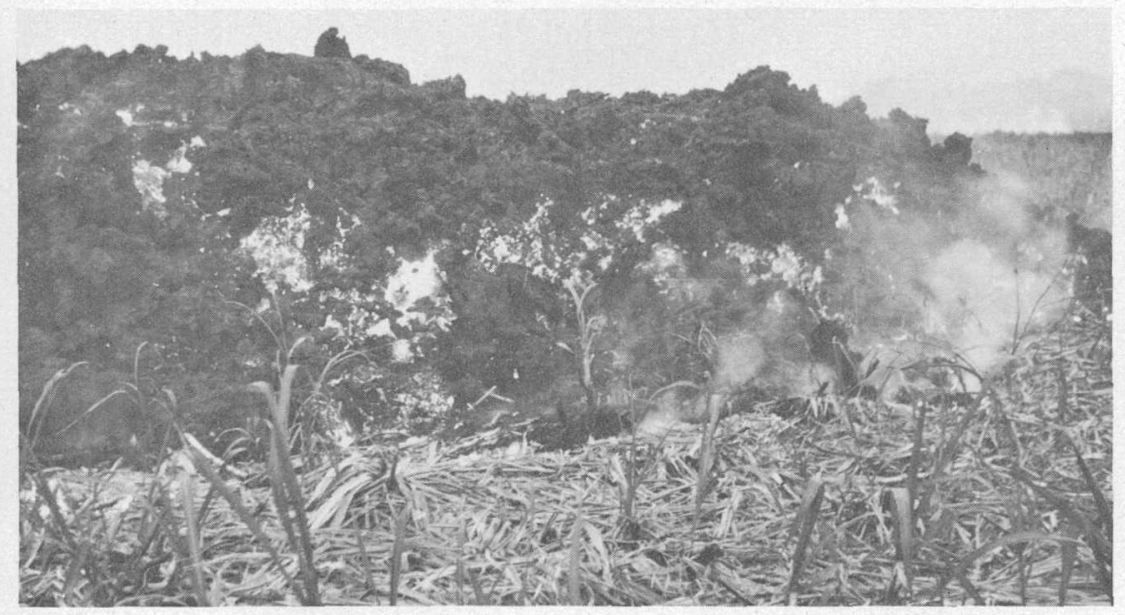

Figure 3.-Margin of an aa lava flow advancing through a field of sugarcane on March 3, 1955. The edge of the flow is here 10 to 12 feet in height and exposes the incandescent still-mobile central part of the flow. 
the flow front. Not until the next afternoon did we learn that although the lava had piled at least 15 feet above the level of the top of the embankment, and a little semisolid clinker from the top of the flow had spilled over, nearly the entire flow had turned southeastward along the embankment into the area south of Kapoho cone.

At $18^{\mathrm{h}} 55^{\mathrm{m}}$ the fountain at vent $\mathrm{M}$ had increased in size until at times it rivaled that at $\mathrm{E}$, which continued to play to heights of 300 to 400 feet. No other vents were active east of $\mathrm{E}$.

Throughout the day of March 3 watch had been kept, principally by employees of Olaa Sugar Co. under the direction of Arthur Lyman, for the appearance of new cracks along the road that follows the old railroad bed through the west edge of Kapoho. Although all residents had been evacuated from the village, work was still progressing on the removal of store stocks and heavy furniture." By evening this removal was virtually complete. At approximately $19^{\mathrm{h}}$ we received word that cracks were opening in the old railroad bed. After confirming the reports, we recommended that everyone leave Kapoho immediately. By $20^{\mathrm{h}} 30^{\mathrm{m}}$ cracks had appeared in the main road in the center of the village, and as we were leaving the village, at approximately $21^{\text {h }}$, we saw dense white fume rising near the upper edge of the village. At about $21^{\mathrm{h}} 30^{\mathrm{m}}$, from a tree at the side of the coastal road 2.5 miles south of Kapoho, J. C. Forbes observed glow at two points east of the previously active part of the rift, one of them apparently in the outskirts of the village. Apparently at that time lava fountains were already active in the village. At $22^{\mathrm{h}} 10^{\mathrm{m}}$ a. National Guard observation plane reported active lava within the village, and at $22^{\mathrm{h}} 15^{\mathrm{m}}$ Deputy Chief George Martin, of the Hawaii Police Department, saw lava fountains in the western part of the village.

March 4.-At $4^{\mathrm{h}} 30^{\mathrm{m}}$. a line of lava fountains approximately 50 feet high extended across the old railroad bed at the west edge of Kapoho $(\mathrm{P}, \mathrm{pl} .1)$ and eastward through the village. A crack 18 inches wide hrad opened across the road in the center of the village and across the shoulder of the old cinder cone, Puu Kea, at the south edge of the village. A lava flow was advancing northeastward north of the village, and several houses had been destroyed.

It was only by great good fortune that the center of Kapoho village escaped destruction by lava. Along the northwest edge of the village lay a northeast-trending ridge of low spatter cones formed during some prehistoric eruption. From vent area $\mathbf{P}$ the fissures extended diagonally across the east end of that ridge and on across a baseball field and through the center of the village. Lava broke out along the fissure almost to the summit of the old ridge. Had the active 
portion of the fissure extended 500 feet farther northeastward, lava would have flowed down the southeast side of the ridge into the village; and if it had extended another 500 feet farther there would have been lava fountains on the highway in the very center of the town. Fortunately, however, the outbreak was confined to the part of the fissure west of the crest of the ridge, and the ridge deflected the lava away from the main part of the village into the valley to the north.

At $7^{\mathrm{h}} 30^{\mathrm{m}}$ the lava fountain at the old railroad bed (P, pl. 1) was still active, but at the easternmost of the Kapoho vents lava activity had stopped and been replaced by a big cloud of steant carrying some dark ash. This appears to have been a mild phreatic steam explosion similar to those near Puu Honuaula on March 1. Lava fountaining at the western Kapoho vents ceased about $10^{\text {h }}$, and by $14^{\mathrm{H}} 30^{\mathrm{m}}$ there was no further movement in the flow north of Kapoho. Light steaming continued at the Kapoho vents through the remainder of the day.

At $10^{\mathrm{h}} 20^{\mathrm{m}}$, from the Kumukahi lighthouse, a column of ash-laden steam was observed rising in the area just west of Kapoho cone. The same column was observed by Mr. and Mrs. Arthur Lyman from the vicinity of Kapoho. The cloud continued for only a few minutes. At $11^{\mathrm{h}} 15^{\mathrm{m}}$ al similar brown column of densely ash-laden steam was again observed in the area west of Kapoho cone. It continued until $11^{\mathrm{b}} 45^{\mathrm{m}}$. These clouds did not rise from the Kapoho vents, but their exact place and mode of origin is not known. From a distance, they resembled the ash-laden phreatic explosion clouds near Puu Honuaula on March 1. During the afternoon several blasts of brown ash-laden gas (steam?) 50 to 150 feet high rose at the margins of flows. These may have been phreatic explosions resulting from the burial of mud in marshy areas.

Early in the morning of March 4 a tongue branched southward from the main lava flow southwest of Kapoho cone and headed in the general direction of Gilbert Hay's residence, on the coastal road 2.5 miles south of Kapoho. During the late morning this new tongue was advancing rapidly, and evacuation of the Hay residence was recommended.

During the afternoon the southern tongue of the lava flow turned eastward and rejoined the main body of the flow. The front of the flow had two main lobes, one of them centered 1.4 miles south-southeast of Kapoho, and the other 0.5 mile farther south. At $18^{\mathrm{h}} 25^{\mathrm{m}}$ the northern lobe of the flow crossed the coastal road. At $18^{\mathrm{h}} \mathrm{5} 5^{\mathrm{m}}$ the southern lobe also crossed the road, consolidating with the northern 
lobe and burying the road for a distance of approximately 0.8 mile. The south edge of the flow was 0.4 mile north of the Hay residence.

On the evening of March 4, the main lava fountain at vent $E$, just southeast of Puu Kii, reached enormous size. From $19^{\mathrm{h}} 30^{\mathrm{m}}$ to $20^{\mathrm{n}}$ measurements obtained by holding a millimeter scale at arm's length, at a distance of 2,750 feet from the fountain, indicate a height for the main core of the fountain of 625 feet, with the tops of occasional jets reaching about 875 feet. The height of approximately 800 feet for the fountain jet was confirmed also by readings on airplane altimeters.

March 5 and 6.-Lava fountains at vents $\mathrm{E}, \mathrm{J}$, and $\mathrm{M}$ continued active on March 5 but were smaller than on March 4. The biggest fountain, at vent $\mathrm{E}$, reached heights of 250 to 300 feet. The lava flow continued to spread slowly in the area between the coastal road and the shoreline.

On March 6 the only activity was in vent area E. During the late morning the main lava fountain had decreased in height to about 150 to 200 feet. On each side of it smaller fountains played to heights of about 25 feet. By $17^{\mathrm{h}}$ the main fountain had disappeared entirely, leaving only a glowing pit in the cone where it had been, but the two lateral fountains continued playing intermittently to a height of about 10 feet. At $23^{\mathrm{h}}$ the activity of the lateral fountains increased briefly, but there was no sign of activity in the main fountain pit. During the morning and early afternoon a very active river of lava had been issuing from the cones, but by late afternoon it had almost ceased to exist. Throughout the day the lava flow continued to spread in the area east of the coastal road, but without reaching the shoreline.

By daylight on March 7 all activity had ceased at the vents, and the lava flow had become stagnant.

THIRD PHASE-MARCH 5 TO APRIL 7

March 5 to 11.-Even before the end of the second phase of the eruption, the preliminaries to the third phase were in progress. At about $12^{\mathrm{h}} 30^{\mathrm{m}}$ on March 5 a new swarm of earthquakes commenced, and during the next few days a very large number of quakes was recorded on the Pahoa seismograph. Many of them were felt in Pahoa and caused some excitement. The source of the quakes was found to be the east rift zone of Kilauea west of the Pahoa-Kalapana road, mostly in the vicinity of Kalalua Crater (12 miles east of the caldera, and 5 miles west-southwest of Heiheiahulu, inset map pl. 1). Because eruption along the part of the rift zone between the Pahoa-Kalapana road and Kalalua Crater might endanger Pahoa, plans were made for the evacuation of the town if it should prove necessary, and a close watch 
was kept by Civil Defense and Olaa:Sugar Co. workers for any sign of lava outbreak along.the rift zone.

During the afternoon of March 5 the excitement was increased by a report of an outbreak northwest of Pahoa. However, on investigation it proved to be brush fire unrelated to volcanic activity.

On March 7 Masayuki Nii reported hearing explosionlike noises emanating from the ground at his farm on the Pahoa-Kalapana road 3.5 miles south of Pahoa. The noises were accompanied by small sharp earthquakes felt on an average of once every 20 minutes. His dog was much disturbed.

By. March 8 it. appeared that a. new outbreak was imminent and that it probably would occur in the vicinity of the Pahoa-Kalapana road. : The likelihood of eruption.was indicated by the very frequent earthquakes originating along the east rift zone of Kilauea at shallow foci between Kalalua Crater (inset map, pl. 1) and Puu. Honuaula, by the noises emanating from the ground and the behavior of animals at the Nii farm, and by the occurrence of what appeared to be volcanic tremor on the seismograms from the area around Kilauea caldera on the afternoon of March 5. Tremor of this sort is known to accompany movement of lava in the volcanic conduits. A police patrol of the Pahoa-Kalapana road and regular aerial reconnaissance of the rift zone by the National Guard were established. Residents of Kamaili were evacuated because of possible danger from lava flows, which might be expected to descend with great speed the steep slope just northwest of that district. Residents of Kalapana and Opihikao were evacuated because of the danger of isolation of those areas from supplies and medical services rather than because of danger directly from volcanic activity. These measures were taken and for several days we waited, while earthquakes were recorded hour after hour at a rate of as much as 2 per minute on the Pahoa seismograph.

March 12.-Finally, on the morning of March 12, cracks appeared in the Pahoa-Kalapana road (in the vicinity of $\mathrm{R}, \mathrm{pl} .1$ ). A police patrol at $4^{\mathrm{h}}$ found no cracking, but about $7^{\mathrm{h}}$ Sgt. Manuel Gill found a 2-inch crack extending across the pavement just south of the Nii farm, 3.7 miles south of Pahoa, and other smaller cracks in a zone extending 0.3 mile northward. These may have opened at the time of three sharp earthquakes between $5^{\mathrm{h}} 45^{\mathrm{m}}$ and $5^{\mathrm{h}} 55^{\mathrm{m}}$. At about $9^{\mathrm{h}} 15^{\mathrm{m}}$ the main crack had increased about half an inch in width, and a new crack extended across the road 2.4 miles south of Pahoa. However, for the remainder of the morning there was no further opening of cracks in the road.

At $17^{\mathrm{h}} 05^{\mathrm{m}}$ lava broke out just southeast of Puu Kaliu (Q, pl. 1), 2.1 miles east-northeast of the main cracks in the Pahoa-Kalapana road. Small lava fountains played at the vents, but dense forest made 
observation of them difficult. Small lava flows spread eastward and southeastward. At about $19^{\mathrm{h}}$ another outbreak occurred at $\mathrm{S}_{1}$ (fig. 4), roughly half way between vent $Q$ and the Pahoa-Kalapana road. The eruptive fissure lengthened slowly westward and by $19^{\mathrm{h}} 45^{\mathrm{m}}$ was about 0.4 mile long. At $23^{\mathrm{h}}$ the fountains at $\mathrm{Q}$ were nearly dead, and those at $S_{1}$ had decreased. A lava flow advanced very slowly southeastward from the vents. At $7^{\mathrm{h}}$ on March 13, the fountains at vent $\mathrm{S}_{1}$ were low and weak, and the front of the lava flow had reached a distance of only 0.25 mile from the vent. At $9^{\text {h }}$ the fountains at vent $S_{1}$ had increased somewhat and were making loud chugging, semiexplosive noises. Fume liberation, previously slight, had become moderately heavy.

March 13.-At $7^{\mathrm{h}} 50^{\mathrm{m}}$ on March 13, Sgt. Teruo Morigaki, of the Hawaii Police Department, observed a new outbreak just east of the Pahoa-Kalapana road $\left(R_{1}\right.$, fig. 4$)$. His attention was first attracted by a roar in the forest, which investigation showed to be caused by a small lava fountain. Soon afterward activity spread southwestward into cleared land planted to coffee and cucumbers $\left(R_{2}\right.$, fig. 4$)$. At $10^{\mathrm{h}}$ a series of about 6 small vents lay along a fissure 250 feet long. Lava fountains were playing to heights of 10 to 25 feet, with occasional

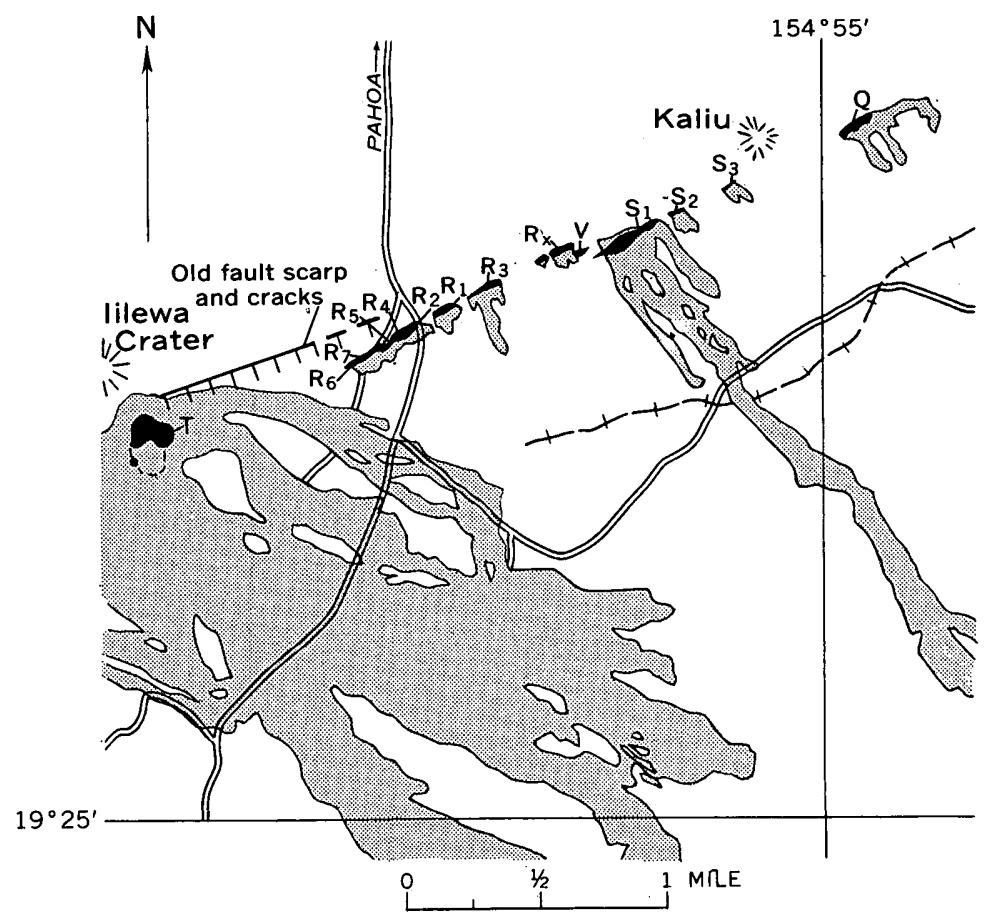

Frgure 4.- Outline map of part of eastern Puna, Hawaii, showing the location of vents $Q, R, S, T$, and $V$ of the 1955 eruption. 
bursts of cinder thrown to about 50 feet. A patch of pahoehoe lava was spreading slowly over the adjacent hillside, but it still covered an area of less than an acre. Cracks were opening across the cleared land to the southwest.

The small flows of pahoehoe along the west edge of the area of activity offered an opportunity for experimenting with the effect of obstacles on the lava. At about $10^{\mathrm{h}}$ we placed a wooden plank, about 8 feet long, 14 inches wide, and 2 inches thick, on edge in a nearly vertical position diagonally across the path of an advancing flow tongue. The great heat of the advancing flow prevented us from providing more than a few loose rocks for support. The lava came into contact with the plank shortly afterwards. The plank immediately started to burn and slowly tilted backward until it stood at an angle of about $60^{\circ}$, but the advance of the flow was deflected along it. The flow front was between 18 and 24 inches high when it first reached the plank, but the depth of the flow gradually increased until the lava against the plank was about 3 feet deep. The flow continued to be deflected to one side for more than half an hour, until another small tongue advanced over the top of the previous tongue and buried the plank.

The remainder of the day brought a series of unprecedented opportunities to observe the complete development of new volcanic vents. The sequence of events had been seen twice before during the eruption, but the outbreaks had been in forest or in sugarcane where the details could not be well observed. On the afternoon of March 13, three separate outbreaks occurred in cleared land adjacent to the road and across the pavement of the road itself, where every detail could be clearly seen.

At approximately $12^{\mathrm{h}}$ a new vent $\left(\mathrm{R}_{3}\right.$, fig. 4 ) opened in the forest east of the vents that had been active all morning. At first the activity of the new vent consisted mostly of roaring gas release, producing a big cloud of fume but little lava.

At $12^{\mathrm{h}} 35^{\mathrm{m}}$ a new fissure opened in the ground in the cleared area $\left(R_{4}\right.$, fig. 4) just southwest of the vents that had been active through the morning. First, a hairline crack appeared, which gradually widened and lengthened to the accompaniment of numerous very local earthquakes. Alongside the growing crack, it felt as though the ground were being heaved up and split open by a series of sharp thrusts, as though a wedge were being driven into it from beneath. Each thrust was accompanied by a sharp bump that felt like a hammer blow on the soles of one's shoes. As the cracks continued to open, wisps of white sulfurous fume, which gradually increased in volume, started to issue from them. The fume had the choking odor of sulfur 
dioxide. At first the fume emission was gentle, but after about 5 minutes the color of the fume changed to pale-bluish white, and pressure increased until the gas was issuing in a series of distinct puffs accompanying the heaves of the ground surface. Approximately 10 minutes after the first appearance of fume from the fissure, a bleb of pasty incandescent lava was blown out in one of the fume puffs. At that time the fissure was 1 to 1.5 inches wide, and a dike of incandescent lava could be seen in it at places 10 or 12 inches below the surface. Showers of small blebs, less than an inch across, followed; and in a minute or two a tiny bulb of red lava appeared at the surface and slowly expanded upward and laterally, while showers of incandescent fragments continued to be thrown from adjacent parts of the fissure.

About 2 minutes after its first appearance, the bulb of lava was approximately 5 inches high, 8 inches wide, and 1 foot in length along the fissure. Every few seconds gas bursts from the top of the bulb threw showers of incandescent spatter 2 to 4 feet into the air.

Fifteen minutes after the first appearance of lava, the active portion of the fissure was about 25 feet long, and a pool of very viscous lava 10 feet wide and 2 feet deep had spread from it. Irregular fountains were throwing showers of ejecta to heights of 5 to 10 feet, with occasional bursts to greater heights. Periods of relative quiet of 2 or 3 minutes duration were terminated by blasts of gas that threw showers of viscous spatter as high as 50 feet. The gas release causing a shower of this sort was not a single abrupt pulse, but a blast rising quickly to a maximum, remaining at that condition for 5 to 10 seconds, and then slowly dying down.

At $13^{\mathrm{h}} 05^{\mathrm{m}}$ the spattering lava had built an elongated conelet 4 feet high, 10 feet wide, and 20 feet long. The bursts of gas had become more explosive and were throwing occasional showers of spatter to heights as great as 100 feet. At $13^{\text {h }} 30^{\mathrm{m}}$ the conelet was approximately 10 feet high.

At approximately $13^{\mathrm{h}} 35^{\mathrm{m}}$ wisps of white fume appeared at new cracks (fig. 5) about 200 feet southwest of the last-formed vent, again in cleared land ( $R_{5}$ fig. 4$)$. The sequence of events was almost identical to that witnessed earlier. The ground was in constant agitation, and the same heaving motion was noted as had been observed at the opening of the previous vent. The crack, which averaged about 10 inches wide at its widest part, opened and closed as the ground recurrently heaved up and settled down again. Fume was blown out as the ground heaved up, then sucked back into the crack as the ground surface sank again. For the most part the fume was white or cream colored, probably a mixture of steam with various other gases, of which sulfur dioxide was very conspicuous from its odor. Some puffs con- 


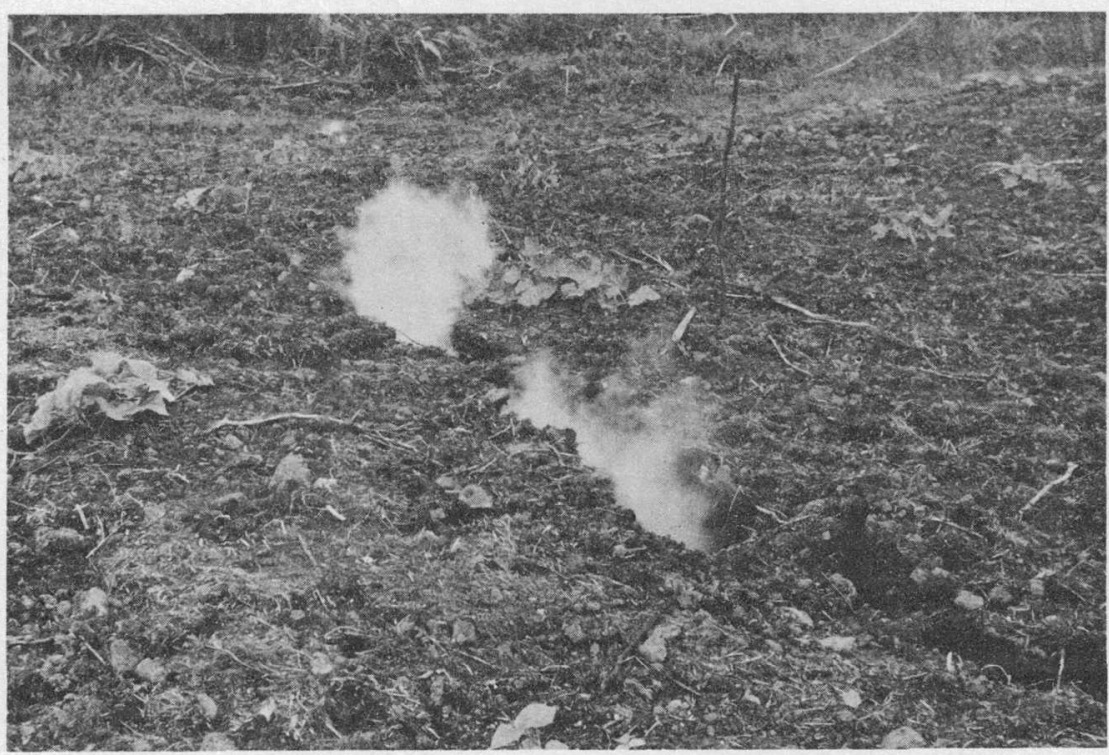

Figure 5.-Fume starting to issue from a new fissure in the soil in vent area $R$ (pl. 1) adjacent to the Pahoa-Kalapana road, at about $13^{\mathrm{h}} 40^{\mathrm{m}}$ on March 13. This is the first phase in the formation of a new volcanic vent. Lava reached the surface at this point a few minutes later.

tained so little condensed steam that they were colorless, yet contained enough sulfur dioxide to be very choking and to sting one's eyes.

The first heat in the escaping fume was noted at $13^{\mathrm{h}} 48^{\mathrm{m}}$. The cracks increased steadily in width and number. At $13^{\mathrm{h}} 55^{\mathrm{m}}$ there were 6 principal cracks, about 50 feet long, in a zone 12 feet wide. A dense white cloud of sulfurous fume was rising from a 30 -foot length of the fissure zone (fig. 6) and blowing off 100 feet before it became dissipated. At $13^{\mathrm{h}} 57^{\mathrm{m}}$ the first blob of incandescent lava appeared at the surface (fig. 7). Gas pressure had increased. Bluish fume hissed from part of the fissure, while elsewhere jets of gas threw up particles of soil torn from the fissure walls.

Gas escape was much more vigorous than at the earlier vent. Within 3 minutes, small fountains had built two piles of lava nearly 1 foot high and 10 feet in diameter (fig. 8). These expanded laterally along the fissure and in another 3 minutes had coalesced to form a lobe of lava 1 foot high, 15 feet wide, and 40 feet long over the fissure. Gas escaping through the lobe of lava was throwing incandescent spatter to heights of 75 to 100 feet. By $14^{\mathrm{h}} 09^{\mathrm{m}}$ the line of vents emitting lava had lengthened to 50 feet, and fume was issuing from 75 feet of additional fissure on each side of the lava vents. At $14^{\mathrm{h}} 15^{\mathrm{m}}$ the line of lava vents was again lengthened 30 feet southwestward. By that time the 


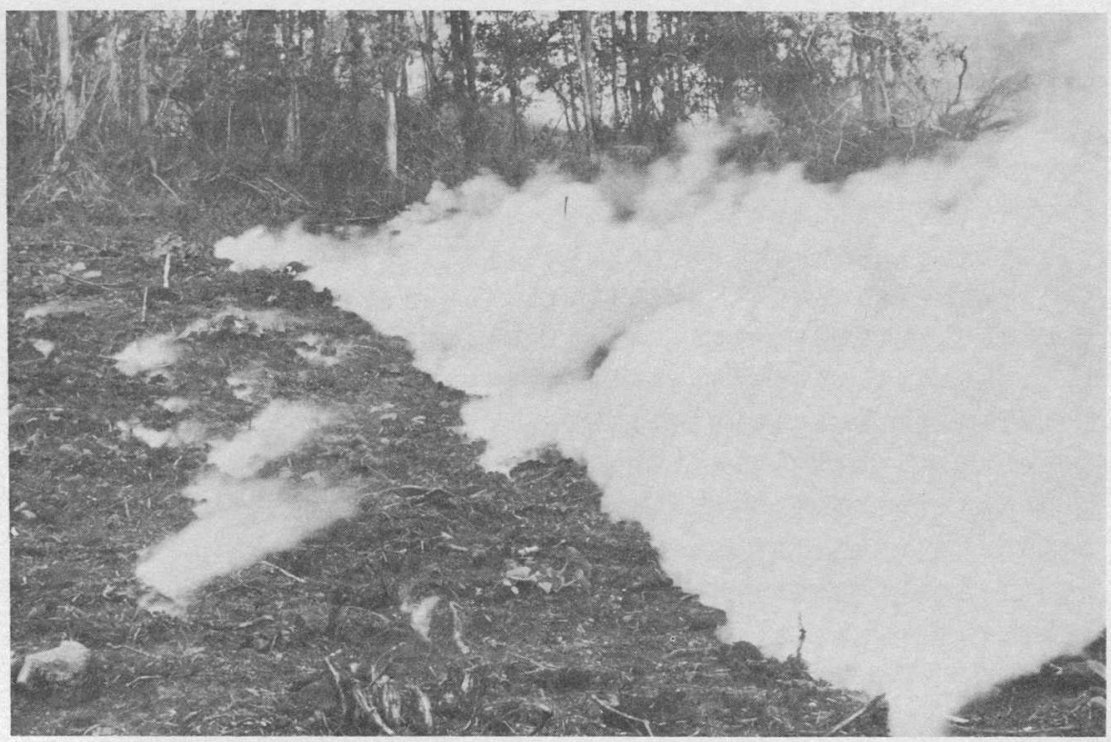

Figure 6.-Fume pouring from the same fissure shown in figure 5 , at about $13^{\mathrm{h}} 50^{\mathrm{m}}$ on March 13.

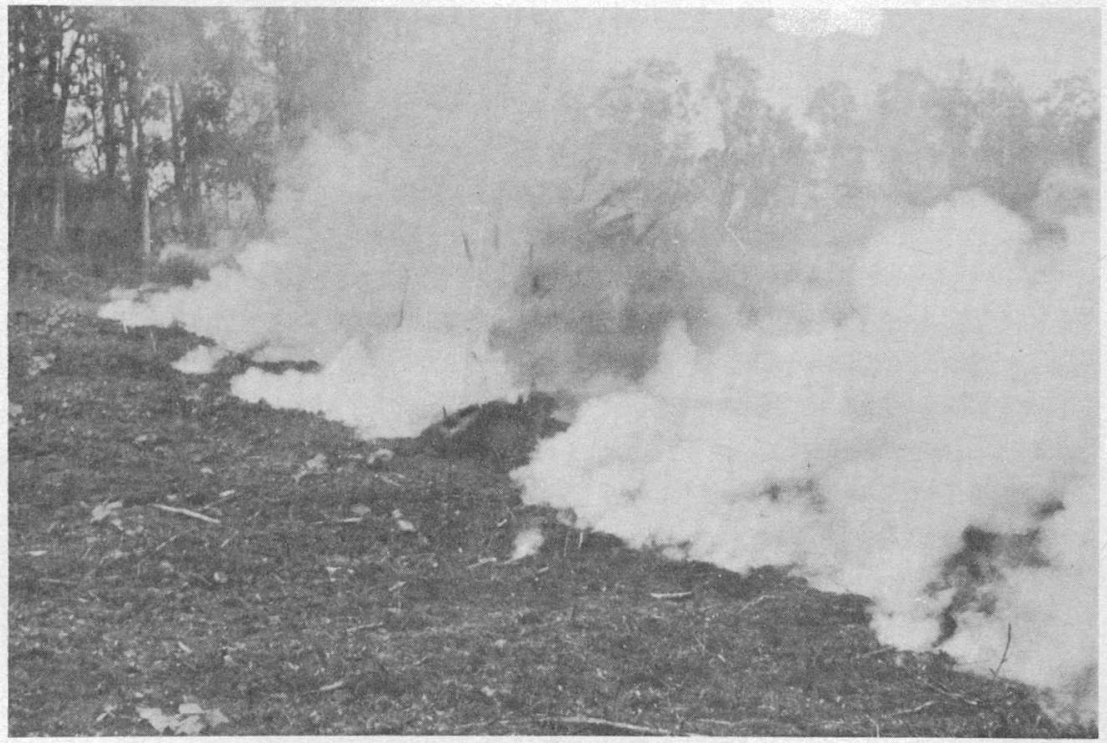

Figure 7.-Lava reaching the surface on the fissure shown in figures 5 and 6 , at about $14^{\mathrm{h}}$. A mound of lava about 6 inches high is visible in the center of the picture, and bits of spatter can be seen in the air above it. 
main vents had built a spatter rampart 2 feet high and 60 feet long, and a lava flow was spreading southeastward.

At $14^{\mathrm{h}} 40^{\mathrm{m}}$ the central 30 feet of the spatter rampart had reached a height of 6 feet, and scattered bursts of incandescent ejecta were reaching heights of 150 feet. The activity consisted mostly of a loud roaring release of gas, accompanied by only a small amount of liquid lava. By $15^{\mathrm{h}} 30^{\mathrm{m}}$ the only remaining activity consisted of mild fuming at both ends of the rift and vigorous gas emission along the central part. Lava activity at vent $R_{4}$ also had ceased.

At $16^{\mathrm{h}}$ still another new fissure opened just west of the PahoaKalapana road, about 1,000 feet southwest of the last previous outbreak, in the front yard of the K. Hayashi residence ( $R_{6}$, fig. 4). A flood of very fluid pahoehoe lava poured from it and spread southeastward, blocking the road by $16^{\mathrm{h}} 11^{\mathrm{m}}$. After the initial voluminous burst, the rate of lava extrusion slowed down, and activity consisted largely of spatter-cone formation.

At about $16^{\mathrm{h}} 15^{\mathrm{m}}$ a fissure started to form across the pavement of the Pahoa-Kalapana road ( $R_{7}$, fig. 4 ) between the sites of the last two outbreaks. By $16^{\mathrm{h}} 20^{\mathrm{m}}$ voluminous clouds of white fume were pouring

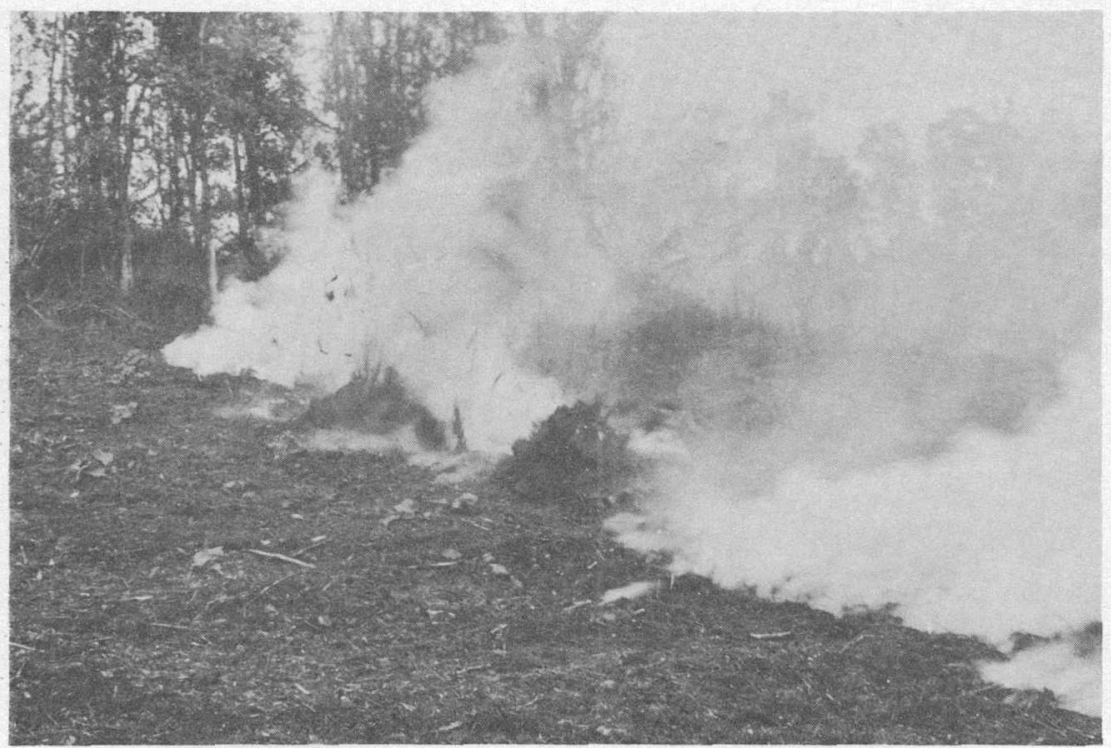

FIGURE 8.-A stage in the development of a new volcanic vent, about 3 minutes later than that shown in figure 7 . The mound of lava in the center of the picture is about 1 foot high. 
from the fissure (fig. 9). At $16^{\mathrm{h}} 22^{\mathrm{m}}$ the first pale-blue fume was observed, and shortly afterward, with the butning of pavement asphalt, brownish smoke appeared. At $16^{\mathrm{h}} 25^{\mathrm{m}}$ the first shred of incandescent lava was blown out, and 2 or 3 minutes later a small mass of very viscous incandescent lava started to bulge up out of the pavement (fig. 10). By $16^{\mathrm{h}} 45^{\mathrm{m}}$ a puffy bulb of pahoehoe averaging about 1 foot high and 2 feet across lay along the fissure across the road (fig. 11), but activity had become mostly roaring gas release accompanied by weak spattering. During the remainder of the evening the fountains grew slowly in size and started to build a row of spatter cones, but little lava was poured out.

The vents at $\mathrm{S}_{1}$ (fig. 4) were visited by Arthur Lyman at approximately $13^{\mathrm{h}}$ and $18^{\mathrm{h}}$. He found gas being liberated, but little or no lava.

At $20^{\mathrm{h}}$ a row of small lava fountains about 400 feet long was still active at vent $R_{3}$ (fig. 4), east of the Pahoa Kalapana road. A flow about 1,000 feet long was advancing downslope from them.

March 14.-At daybreak 4 vents continued active on the fissure across the Pahoa Kalapana road ( $R_{7}$, fig. 4$)$, throwing scattered bursts of cinder to heights of 100 to 150 feet. Spatter cones 15 to 20 feet high had been built across the road (fig. 12). A small, sluggish flow of pahoehoe was moving northward along the road, only about 50 feet from the vents, and another flow was progressing slowly southeastward into the forest. There was no activity in any of the groups of vents farther east, and activity at vent $R_{6}$, in Hayashi's yard, was restricted to very weak lava fountaining.

The vents in the road continued active through the day, and by $15^{\mathrm{h}} 15^{\mathrm{m}}$ the cones were 25 to 30 feet high.

At $14^{\mathrm{h}}$ there occurred a sudden marked increase in the activity of the vents at $R_{6}$. Almost continuous blasts of gas carried fragments of pasty lava to heights of 100 to 150 feet. Bombs pelted the Hayashi house, on the porch of which we had set up an observation station. Several fires were put out by observers, but in spite of these efforts the house burned at about $15^{\mathrm{h}}$.

At $14^{\mathrm{h}} 30^{\mathrm{m}}$ Koji Iwasaki, from his home at the Iwasaki Camp (fig. pl. 1), heard a violent roar of gas and saw a cloud of fume and rock fragments in the air in the vicinity of vent $S_{1}$. This probably marked the beginning of renewed activity at that vent. At $14^{\mathrm{h}} 42^{\mathrm{m}}$ William Stearns, observing from the air, reported a new outbreak already in progress there. A very active flow from vent $S_{1}$ progressed rapidly downslope and at $15^{\mathrm{h}} 16^{\mathrm{m}}$ crossed the Kamaili road 0.7 mile below the vent. 
At $18^{\mathrm{h}} 15^{\mathrm{m}}$ the main fountain at vent $S_{1}$ was very voluminous, playing steadily to a height of 150 feet with occasional bursts to 300 feet. A smaller fountain was playing about 500 feet to the east-northeast of the main one and another, about the same distance to the westsouthwest. Below the main fountain the lava flow descended a slope of $7^{\circ}$ to $10^{\circ}$ with great speed; slowing up and spreading out on the gentler slope farther southeast. On the steep slope near the fountain the flow ranged in width from 50 to 100 feet, but on the gentler slope it was approximately 500 feet wide. At the edge of the flow and up to 100 feet away from it. occasional strong explosions threw showers of old rock fragments and soil into the air. The odor of hydrocarbon gas, probably largely methane, was distinct in the vicinity of these explosions. The explosions. probably resulted from ignition of hydrocarbon gas which had been derived by destructive distillation from vegetation buried by the flow. Migrating away from the flow through tubes in older, underlying lavas, the gas eventually. became mixed with sufficient air to form an explosive mixture (Finch and Macdonald, 1953, p. 60).

:At $22^{\mathrm{h}}$ the main fountain appeared from a distance to have increased somewhat in size. The speed of the central feeding river of the 'flow; on a slope of $8^{\circ}, 0.35$ mile below the cone, was estimated to be about 15 miles per hour.

At $23^{\mathrm{h}} 45^{\mathrm{m}}$ the main fountain was playing steadily to a height of approximately 300 feet, with occasional bursts reaching 400 to 500 feet. The two smaller lateral fountains were still active, and another small fountain was playing about 100 feet west-southwest of the main fountain.

March 15.-At $2^{\mathrm{h}}$ the main fountain at vent $\mathrm{S}_{1}$. was approximately 200 feet high and still very voluminous. A cold wind and mist from the north blew the fumes southward and made it possible to approach close to the fountain on the northwest side, and a slight inclination of the jet toward the southeast caused most of the ejecta to fall on the southeast side, leaving the northwest side of the fountain core unobstructed by fume or falling ejecta. The view of the fountain core seemed to be completely clear, and conditions were as nearly ideal for optical pyrometry as they ever are in field volcanology. Repeated readings with a Leeds and Northrup. pyrometer from a distance of 300 feet from the fountain gave a range from $1,062^{\circ}$ to $1,070^{\circ} \mathrm{C}$, with one aberrant reading of $1,078^{\circ} \mathrm{C}$, and an average of $1,066^{\circ} \mathrm{C}$. Another series of 10 readings from a distance of only 200 feet gave a range of $1,068^{\circ}$ to $1,082^{\circ} \mathrm{C}$, with an average of $1,073^{\circ} \mathrm{C}$. 


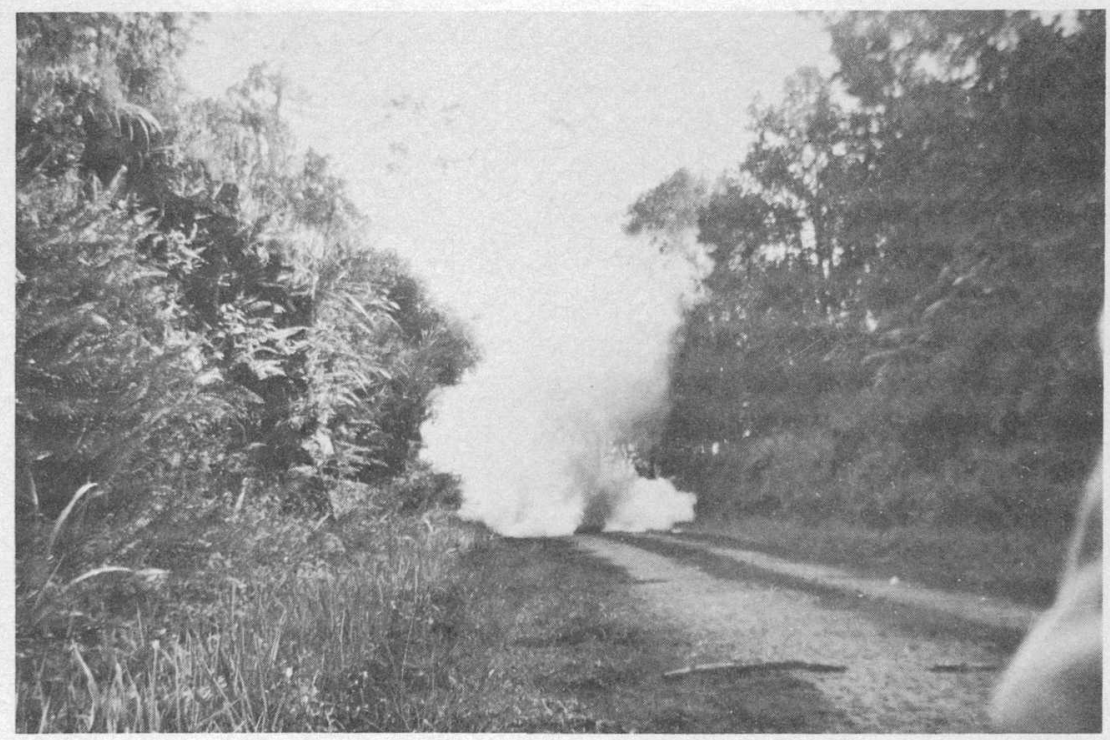

Figure 9.-Fume pouring from a newly opened fissure across the Pahoa-Kalapana road (vent area R, pl. 1) at about $16^{\mathrm{h}} 20^{\mathrm{m}}$ on March 13. Lava reached the surface about 5 minutes later. Photograph by Duncan E. Macdonald.

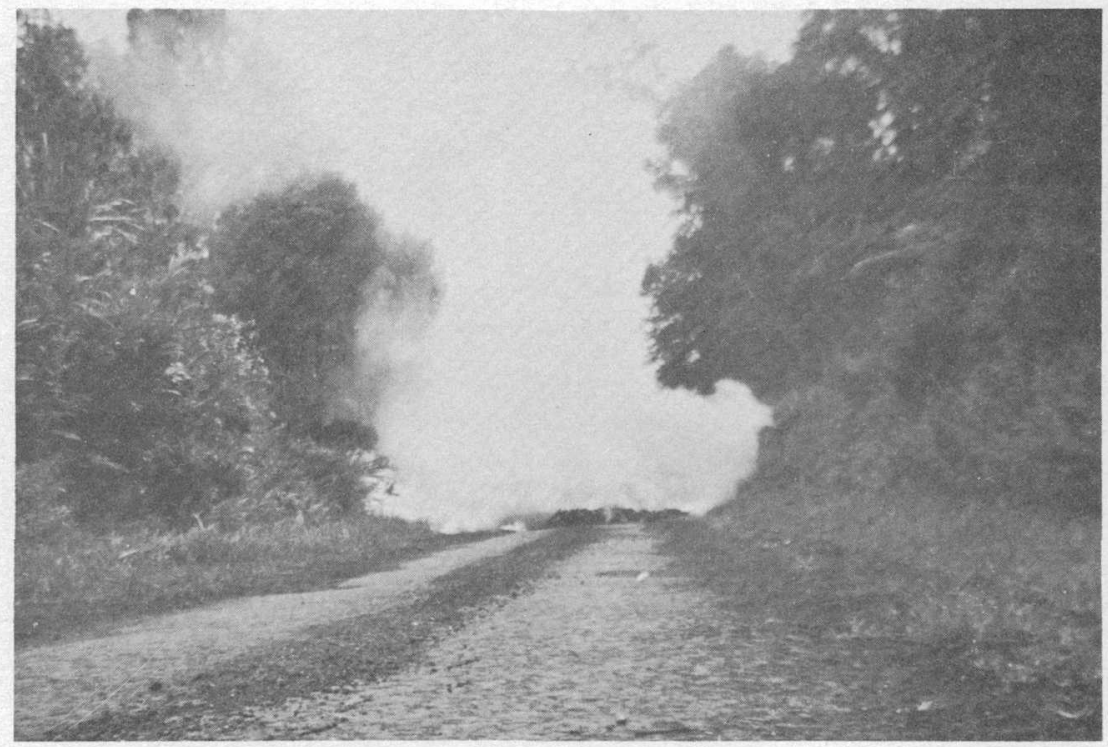

Figure 10.-Ridge of incandescent lava about 6 inches high being pushed up through the pavement at the point shown in figure 9 , about 10 minutes later. Photograph by Duncan E. Macdonald. 


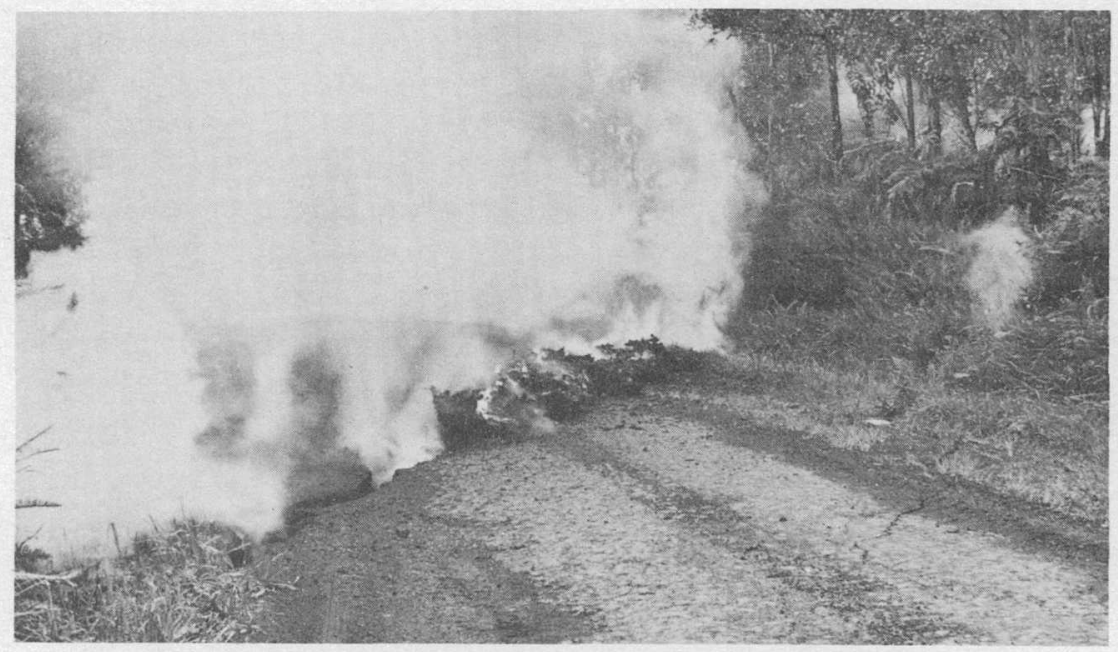

Figure 11. - Closer view of the same mass of incandescent lava shown in figure 10, at about $16^{\mathrm{h}} 45^{\mathrm{m}}, 20$ minutes after the first appearance of new lava at the surface in the fissure across the highway. The bulge of lava is about 1 foot high. Small explosive lava fountains started to burst through the top of the bulge minutes later.

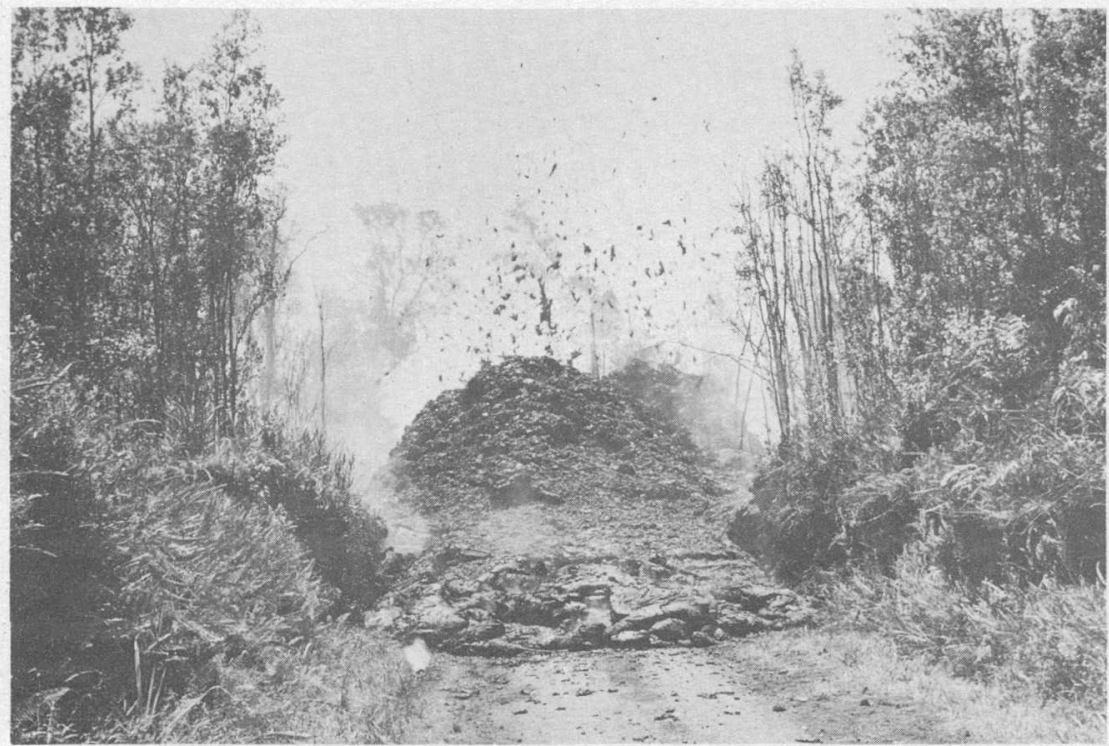

Figure 12.- Spatter cone forming around a small lava fountain at the vent in the PahoaKalapana road shown in figures $9-11$, at about $8^{\mathrm{h}} 30^{\mathrm{m}}$ on March 14,16 hours after the first appearance of lava at the surface. The cone is about 20 feet high. 
Conditions continued much the same through the daylight hours of March 15. At $12^{\mathrm{h}} 15^{\mathrm{m}}$ an estimate of the main fountain at vent $\mathrm{S}_{1}$, made by vertical angle measurement from Puu Kepaka, 1.05 miles to the east, was 425 feet to the top of the highest bursts of cinder. The main flow had spread to a width of about 1,000 feet in the forest 2.2 miles below the vent and was advancing slowly toward the coast. Two other small flows were advancing sluggishly between the vent and the Kamaili road.

Temperature measurements on the fountain made during the evening were markedly inferior to those made the night before, because a large amount of falling ejecta between the core of the fountain and the pyrometer masked the hot core of the fountain. The readings ranged from $1,045^{\circ}$ to $1,068^{\circ} \mathrm{C}$. Unquestionably, the higher readings were more nearly correct.

March 16.-At $5^{\mathrm{h}} 55^{\mathrm{m}}$ the lava flow from vent $\mathrm{S}_{1}$ entered the ocean, having taken approximately 39 hours to travel the distance of 3.15 miles over an average slope of $3^{\circ}$. Throughout most of its course the flow was aa. It poured into the sea very slowly, over a sea cliff 20 feet high. The entrance of the lava into the water was rather quiet. Many jets of steam rose around the edge of the flow, but there 'were no big steam explosions, and even small ones were rare. For the most part, each individual fragment of a clinker rolling into the water produced a small amount of hissing steam, the separate steam jets merging to form a single big cloud that rose, slowly spiraling, almost straight up into the air for about 1,000 feet before it was bent southsouthwestward by the trade wind.

Cutting off the beach road by the flow resulted in the complete isolation of the villages of Kalapana and Kaimu, except for difficult access by the long trail from Makaopuhi Crater in Hawaii National Park.

The flow barely reached the ocean before it stopped. At $8^{\text {h }}$ Arthur Lyman reported the source fountain dead, and at $9^{\mathrm{h}}$ Myron Isherwood could detect no movement of lava at the Kamaili road. At $13^{\mathrm{h}}$ a little movement still continued in the flow at the beach, but by evening all detectable movement had ceased.

This flow has been named the Kaueleau flow because its course lay through the Kaueleau land division.

Shortly after $13^{\text {h }}$ a new outbreak occurred about 0.9 mile southwest of the former westernmost vent at Hayashi's residence. At $12^{\mathrm{h}} 45^{\mathrm{m}}$ a National Guard aircraft observed no signs of lava activity anywhere along the rift, but shortly after $12^{\mathrm{h}}$ Richard Lyman and Richard, Chinen felt very frequent sharp earthquakes, as many as 16 per minute, at the Nii residence just north of vent $R_{7}$ on the Pahoa-Kalapana road. 
At the same locality, at $13^{\mathrm{h}} 45^{\mathrm{m}}$, the surface of a glass of water was kept in almost constant agitation by ground tremors. At about the same time brown fume was observed rising southwest of vent $R_{6}$. At $14^{\mathrm{b}}$ both aerial and ground reconnaisance confirmed the presence of a new, small but vigorous lava fountain in the forest (vent T, pl. 1 and fig. 4) 0.35 mile S. $30^{\circ}$ E. of Iilewa Crater.

The new vent was very short lived. At $15^{\mathrm{h}} 05^{\mathrm{m}} \mathrm{Col}$. Michael Roman, in a National Guard plane, observed a row of four or five fountains about 50 feet in height pouring out lava that flowed southeastward and disappeared into an old crevice. At $15^{\mathrm{h}} 20^{\mathrm{m}}$, Capt. Ken Chaney, also of the National Guard, reported the same fountains still active but apparently dying down. Activity appears to have ceased completely by $16^{\mathrm{h}}$.

At about $14^{\mathrm{h}} 30^{\mathrm{m}}$ Gibert Lee and Reginald Carvalho, of the Territorial Tax Office, observed the opening of a new vent about half a mile southwest of Puu Kaliu (vent $\mathrm{S}_{2}$, fig. 4). At $15^{\mathrm{h}} 30^{\mathrm{m}}$ a small flow from this vent was advancing in the direction of the settlement of Kaueleau. At $15^{\mathrm{h}} 50^{\mathrm{m}}$ still another new vent opened on the southwest slope of Kaliu hill (vent $S_{3}$, fig. 4). At $16^{\mathrm{n}} 35^{\mathrm{m}}$ the latter vent was producing a small but very noisy fountain and a very small lava flow. Vent $S_{2}$ continued active, but the output of lava remained small. At $17^{\mathrm{n}} 05^{\mathrm{m}}$ a sharp earthquake was felt by observers on Puu Kepaka, and activity at vent $S_{3}$ immediately died down greatly.

Weak activity had continued uninterrupted in vent $\mathrm{R}_{7}$ at the $\mathrm{Pa}$ hoa-Kalapana road since March 14. At $20^{\mathrm{h}}$ on March 16 this vent was found to be throwing occasional showers of incandescent cinder to a height of about 50 feet. No lava flow was issuing from it. Vents at $\mathbf{R}_{\boldsymbol{\theta}}$, in Hayashi's yard, were quiet.

At $21^{\mathrm{h}} 40^{\mathrm{m}}$ a bright red glow over the eruption area was observed from Pahoa. Investigation showed that activity had increased at vents $S_{2}$ and $S_{3}$, with vigorous small lava fountains playing at both localities. A bright glow over vent area $S_{1}$ was caused wholly by illumination of the rising fume cloud by the still-incandescent material in the vents. No lava fountaining or extrusion was taking place at vent $S_{1}$.

March 17 :-At. $06^{\mathrm{h}} 50^{\mathrm{m}}$ the pilot of a National Guard aircraft reported that activity. had resumed in vent area. $T$, near Iilewa Crater. Heavy fuming and roaring :gas release continued in vent areas $\mathbf{R}_{6}$ and $R_{7}$, at the Hayashi residence, and on the. Pahoa-Kalapana road, - but there was no lava activity at those localities. - In the vicinity of the Nii residence new cracks were forming and old ones continued opening. 
Between $10^{\mathrm{h}} 10^{\mathrm{m}}$ and $11^{\mathrm{h}} 45^{\mathrm{m}}$ the vents and flows of area $\mathrm{S}$ were investigated. There was strong fuming, but no lava activity at vent $\mathbf{S}_{3}$. Weak fountaining accompanied by loud explosive noises continued at vent $S_{2}$, but there was no extrusion of lava. Only heavy fuming could be detected at vent $S_{1}$, and no movement was taking place in the flows from that vent.

During mapping of the area at a later date, a small vent $\left(R_{x}\right)$ and associated lava flow were found between vents $R_{3}$ and $V$. It is not known when this outbreak occurred, but it may well have been during March 15 or 16.

At $10^{\mathrm{h}} 15^{\mathrm{m}}$ Capt. Ken Chaney, piloting a National Guard plane, reported that the fountains at vent area $\mathrm{T}$ were playing to a height of 75 feet. At $15^{\mathrm{h}} 10^{\mathrm{m}}$ Capt. Elroy Bohlin, also piloting a National Guard plane, found the fountains still in about the same condition and the flow from them extending about a quarter of a mile eastward to a point where it disappeared into a fissure following the base of an old fault scarp that extends southwestward from near vent area $R_{6}$ (fig. 4). From the air he could see lava bubbling in the throats at vent area $S_{1}$, but he saw no sign of incandescent lava in vents $S_{2}$ and $S_{3}$. At $15^{\mathrm{h}} 55^{\mathrm{m}}$ a new finger had formed on the flow from vent $T$ and was advancing southeastward into the forest.

At $19^{\mathrm{h}}$ the pilot of a National Guard plane could detect only glow in vent $\mathrm{T}$, but by shortly after midnight activity had resumed, and showers of cinder were being thrown to heights of 100 to 150 feet.

March 18.-During the morning vents $\mathrm{R}_{6}$ and $\mathrm{R}_{7}$ remained quiescent, except for gas release, which was in part a gentle liberation of white to pale-brown fume, and in part a roaring release of very pale bluish to colorless fume. The throats of the vents continued to glow with bright-orange incandescence. Cracks in the Pahoa-Kalapana road and in the yard of the Nii residence continued to liberate clouds of white choking sulfurous gas. Vents $S_{1}, S_{2}$, and $S_{3}$ continued to fume heavily, but they showed no signs of lava activity.

Conditions at vent $\mathbf{T}$ remained about the same as the night before. At $8^{\mathrm{h}} 15^{\mathrm{m}}$ scattered bursts of cinder and spatter were being thrown to a height of about 100 feet, with an almost continuous series of discrete roaring and hissing detonations one after another. At $13^{\mathrm{h}} 15^{\mathrm{m}}$ the pilot of the National Guard plane reported that three spatter cones had been built, the largest of them about 50 feet high.

Activity at vent $T$ increased rapidly during the afternoon. At $14^{\mathrm{h}} 35^{\mathrm{m}}$ a fountain 300 feet high was playing at the southwest end of the fissure. A strong flow of lava was moving eastward from the cone, partly disappearing in the old fissure, and partly burning its way through the forest toward a house on the Pahoa-Kalapana road. 
During the evening vent $R_{7}$, on the Pahoa-Kalapana road, revived briefly. At $23^{\text {h }}$, James Miller of Pahoa School found this vent throwing up occasional weak showers of incandescent cinder to a height of about 30 feet.

March 19.-At daybreak activity remained much as it had been the night before, except that vent $R_{7}$ had returned to inactivity. At $9^{\mathrm{n}} 45^{\mathrm{m}}$ Arthur Lyman reported a new outbreak at vent $U$ (pl. 1), 1 mile southwest of Iilewa Crater. At $10^{\mathrm{h}} 05^{\mathrm{m}}$ the pilot of the National Guard plane reported heavy fume in that area, but could discern no lava activity. At $13^{\mathrm{h}}$ the noise of small lava fountains was clearly audible in the forest. At $14^{\mathrm{h}} 15^{\mathrm{m}}$ the National Guard pilot reported a line of five lava fountains active in vent area $U$ and two lava flows advancing rapidly east-southeastward and south-southeastward respectively. It was estimated that the latter would cross the Pahoa-Kalapana road in about 3 hours.

Cutting of the road would result in a serious situation. A group of about 20 evacuees had been given permission to return to Kalapana to feed livestock and bring out some personal possessions. The route following had been a trail west of vents $R_{7}, R_{6}$, and $T$, and back to the Pahoa-Kalapana road about 1 mile south of vent $R_{7}$. If the new flow blocked the road farther south, return by the same route would be impossible. Therefore leaflets were dropped from the National Guard plane warning the people to return immediately. There was some delay in getting the message to all members of the group, and by the time the group had started back up the road still another difficulty had arisen. A shift in wind carried the dense cloud of choking fume from the vents in the vicinity of $R_{i}$ directly across the trail west of the vents, effectively closing it to all passage. Curtis Kamai and Macdonald made their way around the east side of the vents and intercepted most of the people on the road before they reached the trail. A few who arrived earlier attempted to cross by way of the trail but were driven back by the fumes. Eventually, all were brought out safely around the east side of the vents. Even on the east side of the vents, there was considerable choking fume, but the people were instructed to cover their noses and mouths with wet cloths, and the trip through the fume cloud was made without great difficulty. With the exception of one man, who required oxygen treatment because of cardiac trouble, there were no casualties.

At about the time of the outbreak at vent $U$, activity at vent $\mathbf{T}$ decreased to a very low ebb and remained that way for the remainder of the day. 
At $10^{\mathrm{h}} 25^{\mathrm{m}}$ the National Guard pilot reported white "smoke" at two localities, one approximately 3 miles and the other 6 miles west-southwest of Iilewa Crater. These appear to have been steam vents on the east rift zone of Kilauea. During the succeeding 2 weeks similar steam clouds were observed repeatedly at points along the rift zone from near Napau Crater (insert map, pl. 1) to near Heiheiahulu, in addition to the usual steaming areas at Kokoolau, Aloi, and Makaopuhi craters. All appeared to be at places where steam had issued previously, but unquestionably the amount of steam was greater than usual, probably because of heating of the rift zone at moderate depth.

The lava flow from vent $U$ crossed the Kaimu Homestead road at approximately $18^{\mathrm{h}} 30^{\mathrm{m}}$. Poor visibility prevented observation of the time it passed the Pohoa-Kalapana road.

March 20.-At daybreak the fountains at vent U continued small but very active. A large volume of lava was being poured out in three flows, the easternmost of which extended about 600 feet beyond the Pahoa-Kalapana road. Vent $\mathrm{T}$ also continued moderately active.

At $8^{\mathrm{h}} 30^{\mathrm{m}}$ three bulldozers, operated by Wallace and Henry Chow and Alfred Lee, began construction of an emergency road across the flow from vent $S_{1}$ along the former route of the Kamaili road. At $10^{\text {h }}$ the road was finished sufficiently to permit us to cross the flow, accompanied by a National Guard radio jeep. This construction was done only $51 / 2$ days after the flow had crossed the road and only. 3 days after the flow had stopped moving. The lava was aa, easily moved by bulldozers. It was still very hot, but experience in building a new road over the edge of the flow from vent $A$ had given the operators confidence, and they undertook the work without hesitation.

At $9^{\text {h }}$ C. E. S. Burns, manager of the Olaa Sugar Co., reported from the air that the fountains at vent $U$ were nearly dead and that the discharge of lava had decreased greatly. At $10^{\mathrm{h}} 30^{\mathrm{m}}$ there was still movement in the flow across the Pahoa-Kalapana road, but by $11^{\text {h }} 30^{\mathrm{m}}$ no movement was visible.

About noon, the fountain at vent $T$ began to increase in size, and by $14^{\text {h }}$ it was reaching a height estimated at 500 feet. At the same time the volume of lava being extruded also increased. Most of the lava flowed southeastward.

The first tongue : of the flow from vent $T$ crossed the PahoaKalapana road at $17^{\mathrm{L}} 03^{\mathrm{m}}$. . Part of the lava continued southeastward beyond the road, but part turned and followed the road almost on a topographic contour. The flow front advanced down the road at a rate of several feet per minute.: As it advanced, fragments of incandescent material up to 2 feet across tore out of the plastic part of the flow:near the top of the front, just beneath the cooler surficial layer of 
black clinker, and rolled as angular chunks down the front of the flow. On striking the pavement they broke into several separate fragments each of which then flattened out under its own weight. Thus the material was at the same time capable of both fracture and flow.

At $18^{\mathrm{h}} 45^{\mathrm{m}}$ rough measurement of the angle subtended by the fountain at a distance of 6,000 feet indicated that its height was more than 700 feet. The fountain had the appearance of a great flame. Jets of incandescent pumice shot to great heights, cooled and disappeared, their fall being invisible in the darkness.

At $16^{\mathrm{h}} 03^{\mathrm{m}}$ a sharp explosion in the vicinity of vent area $R$ threw a cloud of black ash to a height of about 500 feet. At the time, we were 1 mile to the south, waiting for the lava flow from vent $T$ to reach the road, and no observers were in the area near the explosion. A few minutes later, however, Captain Chaney reported from the air the discovery of a new, small pit crater at vent $R_{5}$. The crater was merely a hole perforated in the ground surface, with a nearly circular opening about 25 feet across (fig. 13). The walls were overhanging and glowed a bright orange red even in daylight. No bottom could be discerned. The original perforation of the crater to the surface almost certainly occurred at the time of the explosion at $16^{\mathrm{h}} 03^{\mathrm{m}}$. Several other, similar but smaller, explosions occurred later. At $17^{\mathrm{h}} 20^{\mathrm{m}}$ a little

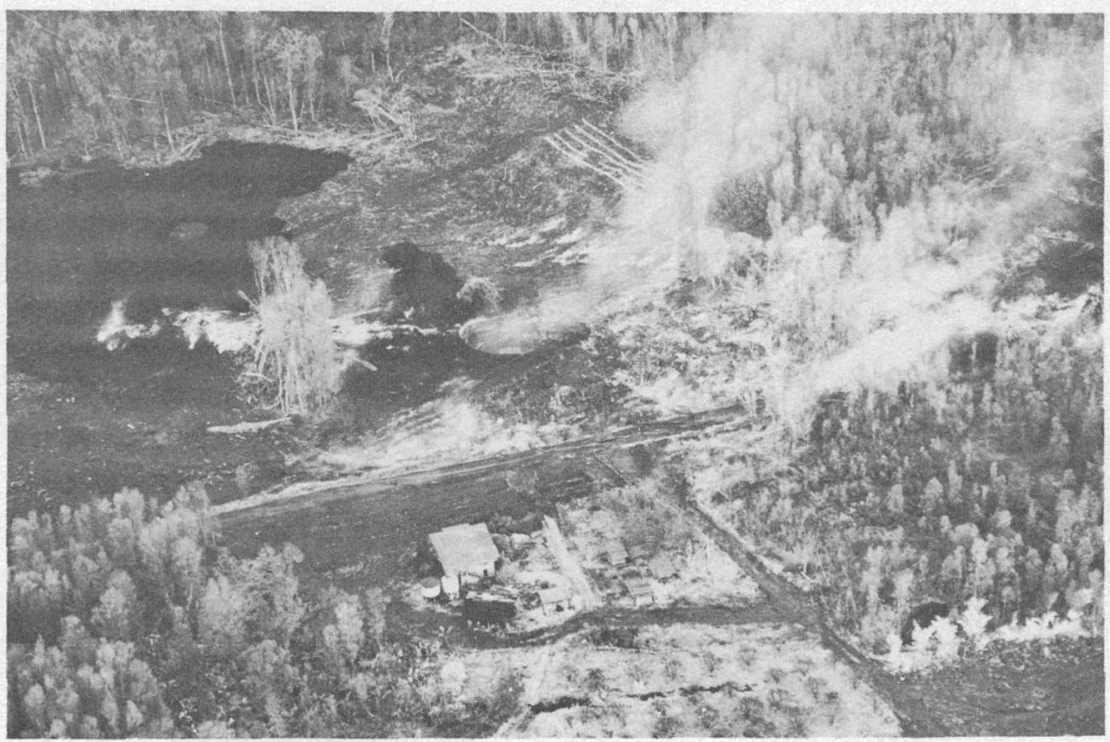

Figure 13.- Small pit crater formed by collapse at vent $R_{5}$ (fig. 4 ) on March 20. The crater opening was about 30 feet across at the time the photograph was taken, on March 24. Extending to the left of the crater is the row of spatter cones built at vents $\mathrm{R}_{4}$ and $\mathrm{R}_{5}$ on March 13 . 
fine cinder was being blown into the air from the crater, and later examination showed the ground around the crater to be covered with relatively dense glassy ejecta, many of them Pele's tears. The walls of the crater were largely covered with festooned sheets of lava (fig. 14). It appeared certain that fusion of the wall rocks had taken place, and much of the glassy ejecta probably was derived in this manner and blown out by the rapidly escaping colume of gas.

At about $22^{\mathrm{h}}$ a tongue of pale-blue and yellow flame 15 to 20 feet high was playing over the mouth of the new crater.

During the evening the lava flow continued across the road and entered the upper edge of the cane land, at times advancing as much as 1,000 feet per hour. Measurements on brightly incandescent parts of the rapidly moving flow front gave temperatures of $1,025^{\circ}$ to $1,065^{\circ} \mathrm{C}$.

March 21.- Between midnight and $0^{\mathrm{h}} 30^{\mathrm{m}}$ the size of the main fountain at vent $T$ decreased abruptly to a height of 100 to 150 feet. At the same time the amplitude of volcanic tremor on the Pahoa seismograph decreased greatly. At about $1^{\mathrm{h}} 30^{\mathrm{m}}$ the activity of the fountain increased again, but erratically, and the fountain did not regain the great size of the previous afternoon and evening. At $10^{\mathrm{h}} 20^{\mathrm{m}}$ it was estimated to be 200 to 250 feet high.

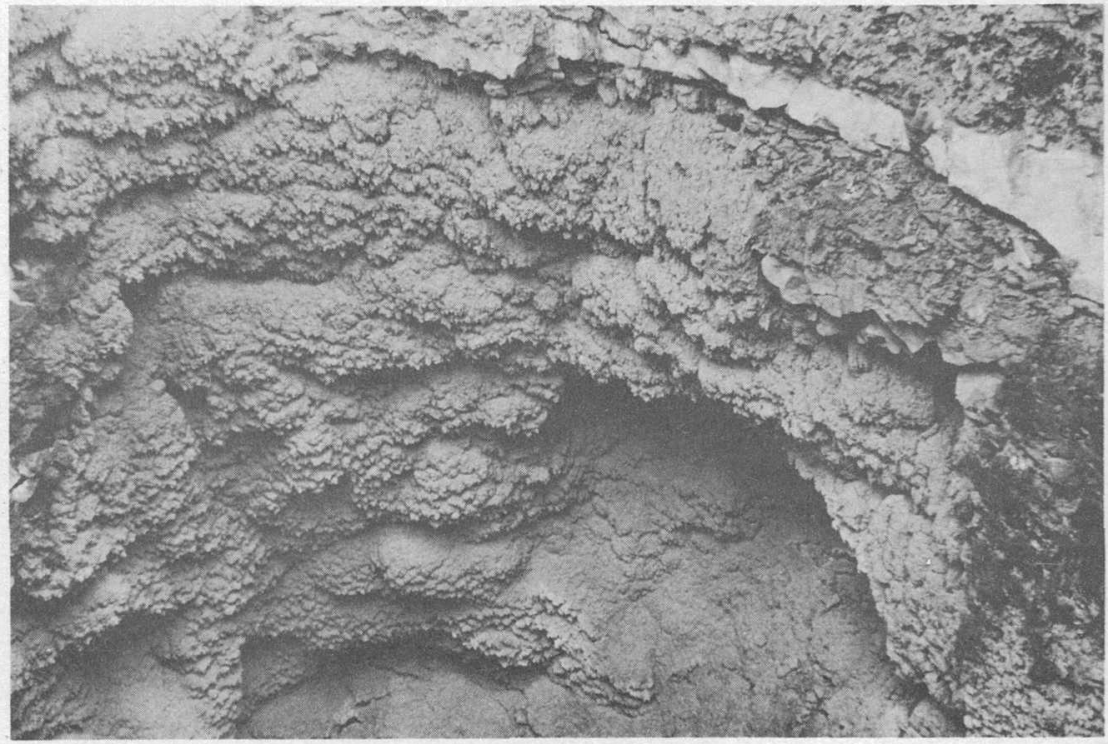

Frgure 14.-Festoons of lava on the wall of the pit crater at vent $R_{5}$, formed by dripping of re-fused rock of the crater wall. 
The main part of the lava flow from vent $T$ continued to advance southeastward a quarter of a mile south of the Iwasaki Camp. Through most of the day the lava fountain ranged from 200 to 400 feet high.

During the afternoon, two flights were made over the new crater at vent $R_{5}$ (across the road from the Nii residence). It was a typical small pit crater with overhanging walls. The opening was estimated to be about 20 feet across at the surface and 50 to 100 feet deep. The amount of overhang of the walls was difficult to ascertain, but it appeared to be 15 or 20 feet on all sides except the southwest, where it appeared to be at least 50 feet. The walls glowed bright orange in full daylight.

At $21^{\mathrm{h}} 20^{\mathrm{m}}$ the same crater was viewed from the ground. A tongue of flame flickered over it, much as it had the night before. The glow from the crater, reflected on the fume cloud above it, was light lemon yellow, indicating a temperature probably in excess of $1,000^{\circ} \mathrm{C}$. Because of the overhanging walls, it was considered unsafe to approach close to the rim of the crater.

March 22.-During the night the lava fountain (vent $\mathrm{T}$ ) continued high and ejected large amounts of pumice and Pele's hair. The latter fell abundantly in Pahoa, 5 miles away, forming a layer nearly 1 inch deep on roofs. The domestic water supplies in Pahoa are derived wholly by catchment of rainwater on roofs and storage in tanks. Pumice and Pele's hair were washed into the tanks and caused mechanical pollution of the drinking water. The problem was easily solved, however, by tying small cloth sacks over the ends of the faucets.

At some time between midnight and daylight, a new tongue of lava started from vent $T$ and advanced southeastward along the south side of the older flow. By $9^{\mathrm{h}}$ the front of the new tongue was already 1,500 feet below the Pahoa-Kalapana road and was advancing rapidly through the forest.

At $8^{\text {h }}$, bulldozers started work on a road across the Kaueleau flow (pl. 1) at the beach. The road was completed for traffic at $9^{\mathrm{h}} 30^{\mathrm{m}}$, although the lava remained very hot.

At $12^{\mathrm{h}} 15^{\mathrm{m}}$ and again at $14^{\mathrm{h}}$ a puff of black ash-laden smoke rose from the locality of the new crater (vent $R_{5}$ ). At both times a single puff, lasting only a few seconds, sent a rolling, convoluting black cloud to a height of about 1,000 feet.

At $15^{\mathrm{h}} 45^{\mathrm{m}}$ the new crater was giving off a cloud of magenta dust and fume, which rose in swirling gusts. The gas was very acrid and sulfurous. The upper walls of the pit consisted mostly of the cleanly broken edges of older lava flows, but at many places, particularly on the northeast side, the wall was covered by a sheet of new lava and 
stalactites. Many new cracks had formed around the crater, most of them more or less concentric to it, and it was apparent that the entire surface for at least 200 feet outward from the rim of the crater was sinking and tilting inward toward it.

Activity at vent $\mathrm{T}$ continued unchanged during the day (fig. 15), and the new flow tongue continued to advance. By nightfall the front of the tongue was about 3,000 feet southeast of the Pahoa-Kalapana road.

March 23.-A strong outflow of lava continued at vent $\mathrm{T}$ but it was almost all going into the newer flow farther northwest.

Throughout most of the day heavy rain and mist obscured the lava fountain at vent $\mathrm{T}$ from view. During the evening the weather cleared, and the fountain appeared much reduced in size. At $21^{\mathrm{h}} 45^{\mathrm{m}}$, Civil Defense warden Albert Wilson reported that it was only about 75 feet high. About $22^{\mathrm{h}} 30^{\mathrm{m}}$ activity again increased, however, and at $23^{\mathrm{h}}$ it reportedly shot to heights as great as 400 feet. A bright glow in the sky over the vent was visible from Pahoa.

March 24. - At about $3^{\text {h }}$ a new flow broke out through the north base of the cone at vent $\mathrm{T}$ and started to advance eastward through the forest. By $9^{\mathrm{h}} 40^{\mathrm{m}}$ it had stopped, however. Throughout the day and the succeeding night the fountain maintained its height, and a large amount of lava poured southeastward into the flow directed toward the Yamada plantation and the newer flow farther south. At

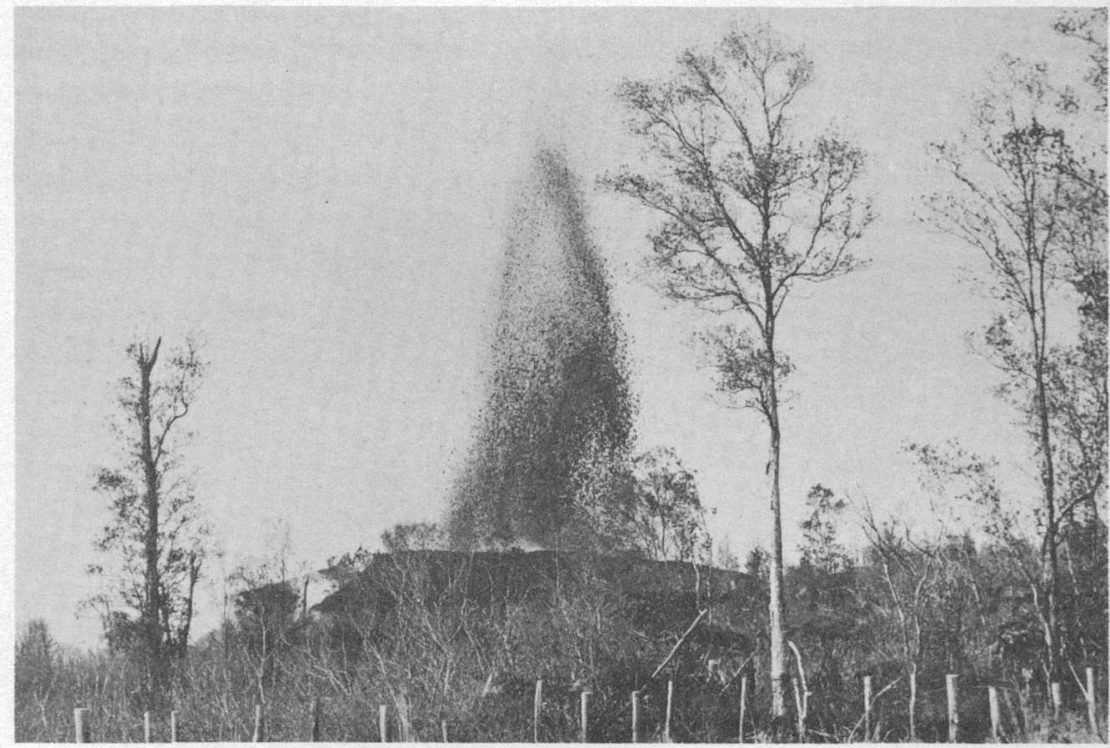

FIGURE 15.-Lava fountain at vent $T$ and cinder cone at its base, seen from the north at about $11^{\text {h }}$ on March 22 . The fountain is about 300 feet high. 
$19^{\mathrm{h}} 20^{\mathrm{m}}$ vertical angle measurements from a distance of 1,800 feet indicated that the cone was approximately 130 feet high and that the fountain rose 200 feet above the top of the cone. A new vent had opened on the northeast side of the cone during the afternoon and was making loud blowing noises. For several days the activity of this new vent consisted wholly of noisy gas emission, and it became known as the Blowhole (fig. 16).

Aerial reconnaissance of the east rift zone during the morning revealed two new steaming localities, one approximately 2.1 miles and the other 3.3 miles west of Heiheiahulu. Heavy fume was rising from the vents in area $U$ (pl. 1). Light clouds of steam were issuing at vents $\mathrm{E}$ and $\mathrm{J}$ and dense clouds at vent $\mathrm{M}$. The latter continued to steam heavily throughout the rest of the eruption and for months afterward.

March 25.-At $8^{\mathrm{h}} 45^{\mathrm{m}}$ the mouth of the pit crater at vent $\mathrm{R}_{5}$ was about 45 feet long and 25 feet wide, elongated east-northeastward along the eruptive fissure. From the length of time required for a rock to fall to its bottom, it was estimated to be 150 feet deep. The rim was crumbling off frequently and the walls consequently becoming more nearly vertical. At $14^{\mathrm{h}}$ the crater mouth had enlarged 10 feet since the morning. Activity at vent $\mathbf{T}$ continued unchanged.

At $9^{\mathrm{h}} 55^{\mathrm{m}}$ Captain Bohlin and Eaton observed from the air the formation of a new vent (V, pl. 1 and fig. 4), 0.85 mile east-northeast of the pit crater. A line of fountains 100 yards long formed quickly in the forest, and a flow of pahoehoe started to spread southeastward. At $10^{\mathrm{h}} 30^{\mathrm{m}}$ Raymond Suefuji, Civil Defense mapper, estimated the fountains to be 80 feet high and the flow to be about 100 feet long. However, activity at the new vent was very short lived. By $13^{\mathrm{h}}$ both the flow and the fountains had stopped. The total length of the flow was only about 350 feet. The fissure on which this outbreak occurred is between the fissures of the $\mathrm{R}$ and $\mathrm{S}$ series of vents, and lies en echelon to both.

During the afternoon most of the lava from vent $\mathrm{T}$ again went into the southernmost flow. By $17^{\mathrm{h}}$ the flow near the Iwasaki Camp was again stagnant, and only very slow movement was taking place near the Yamada coffee field. At $22^{\mathrm{h}}$ the movement could barely be detected.

March 26.-At $8^{\text {h }}$ the core of the fountain at vent $T$ (pl. 1 and fig. 16) was playing to heights of 75 to 100 feet above the top of the cone, with occasional bursts of scattered cinder reaching twice that height. Captain Bohlin, flying over the area at $9^{\mathrm{h}} 30^{\mathrm{m}}$, could detect movement only in the southernmost tongue of the flow. At $10^{\mathrm{h}} 30^{\mathrm{m}}$ no movement could be detected at the Yamada plantation or in the part of the flow farther northeast. At $11^{\mathrm{h}} 15^{\mathrm{m}}$ an aa tongue, branching 
from the main flow, was advancing at the rate of a few feet per hour into the space between the main flow and the southern branch. The front of this tongue was 25 to 30 feet high.

At $11^{\mathrm{h}} 45^{\mathrm{m}}$ the fountain at vent $\mathrm{T}$. was nearly inactive, but by $13^{\mathrm{h}}$ it was again active and spouting intermittently to heights of 50 to 100 feet. During the afternoon gas samples were collected at fumaroles just northeast of the big cone at vent T by Prof. J. J. Naughton of the University of Hawaii. Temperatures in the same fumaroles, measured with a standardized thermocouple, ranged from $550^{\circ}$ to $610^{\circ} \mathrm{C}$. In a tree mold in which deep red incandescent lava was visible at the base, about 5 . feet below the surface of the flow, the temperature was $785^{\circ} \mathrm{C}$. No sign of movement could be detected in the flow, but the underlying terrain was nearly horizontal.

At $17^{\mathrm{h}} 30^{\mathrm{m}}$ several loud explosions occurred at vent $\mathrm{T}$, and immediately afterward the fountain spurted up to a height of about 300 feet. A partial breakdown of the southeast side of the cone apparently had

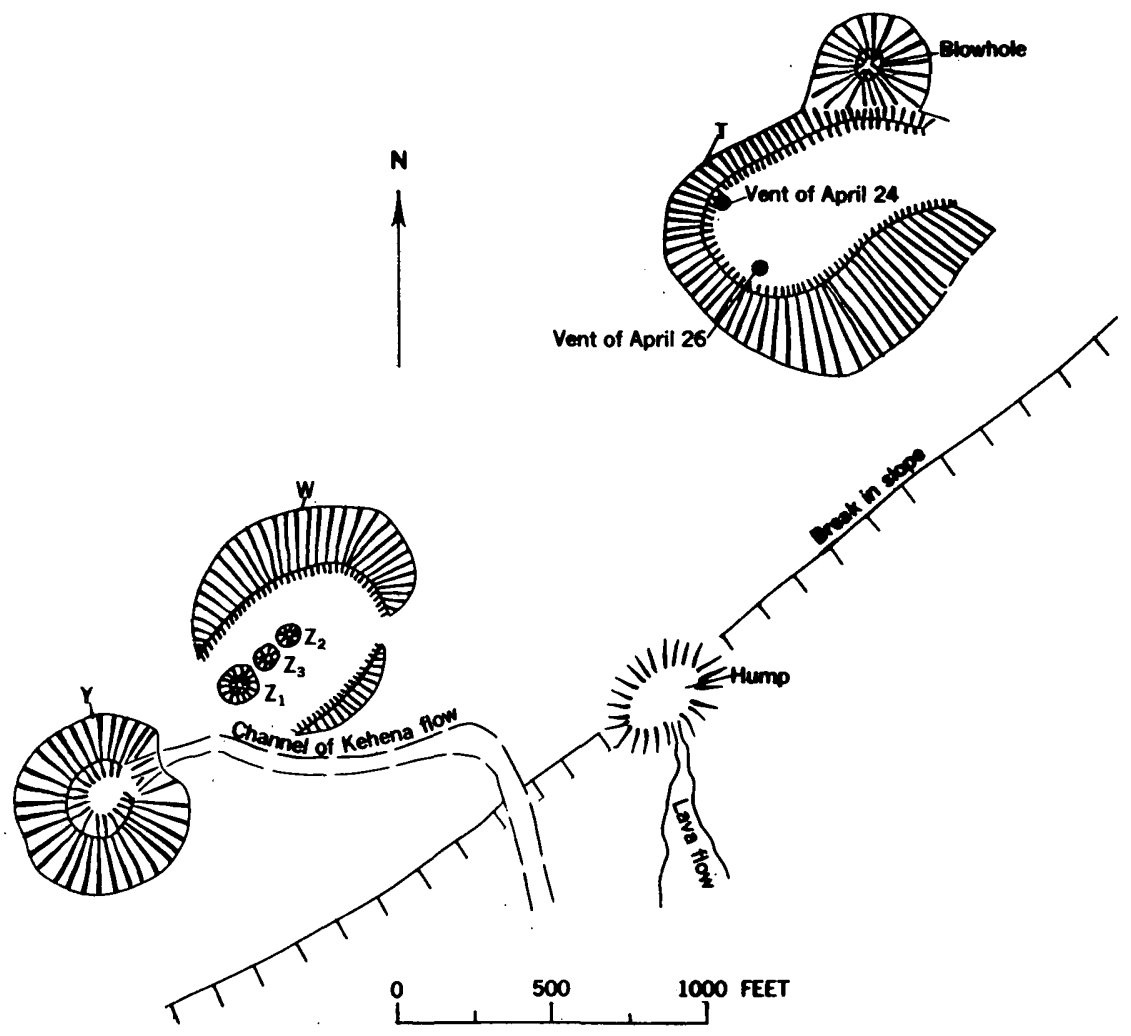

Froure 16. - Sketch map of part of east Puna, Hawall, showing the location of vents $T$, $W, Y$, and $Z$ of the 1955 eruption and otber topographic features mentioned in the text. 
released a pool of lava that had been held at high level within the cone and had been damping the fountain blasts, greatly reducing their height. The fountain shrank in size within the next few minutes, but it remained larger than before the explosions. At $18^{\mathrm{h}} 45^{\mathrm{m}}$ it was approximately 200 feet high.

During the afternoon lava was discharged from vent $T$ southeastward into the flow in distinct surges, which traveled down the flow at intervals of 15 to 20 minutes.

At $20^{\mathrm{h}}$ an aircraft reported a new outbreak (vent W, pl. 1 and fig. 16), 1,500 feet west-southwest of vent $T$. At $21^{\mathrm{h}}$ investigation on the ground revealed a line of fuming fissures extending southwestward from vent $T$ and, at its end, a chain of lava fountains 20 to $30^{-}$feet high and 250 feet long. The fountain at vent $\mathrm{T}$ continued to play to heights of 150 to 200 feet.

At $21^{\mathrm{h}} 15^{\mathrm{m}}$ a new lava fountain appeared at the vent known as the Blowhole, on the northeast side of the big cone at vent $T$. Lava was flowing southeastward from both vents $\mathrm{T}$ and $\mathrm{W}$.

At $22^{\mathrm{h}} 30^{\mathrm{m}}$ a big lateral overflow of the main lava flow sent a very active tongue of aa into the gully at the southeast side of the Iwasaki camp. The village did not appear to be in direct danger from the lava, but fire engines were summoned to stand by in case brush fires should spread toward the houses.

At $22^{\mathrm{h}} 45^{\mathrm{m}}$ a series of noisy explosions began at vent $\mathrm{T}$ and continued at irregular intervals for the next 2 hours.

March 2\%.-At $1^{\mathrm{h}}$ the activity at vent $\mathrm{W}$ consisted of three fountains along a fissure about 250 feet long, playing to a height of 100 feet. At vent $\mathrm{T}$ the main fountain was playing to a height of 100 to 150 feet. The fountain at the Blowhole, on the northeast side of the cone, had become inactive. By $1^{\mathrm{h}} 15^{\mathrm{m}}$ the activity at the main vent $\mathrm{T}$ had become weak and intermittent, and occasional showers of redhot cinder were being thrown to a height of about 50 feet. At approximately $2^{\mathrm{h}}$ activity at vent $\mathrm{T}$ ceased altogether, and, simultaneously, the fountains at vent $W$ increased in height to about 200 feet.

At $1^{\mathrm{h}} 30^{\mathrm{m}}$ the flow tongue at the Iwasaki Camp had become stagnant without damaging the camp, but movement still continued in the main flow farther south. During the previous evening a new flow had started from vent $W$ and advanced southeastward very rapidly along the south side of the flow from vent $T$. By $3^{\text {h }}$ the front of this new flow was reported to be nearly 1 mile southwest of the Pahoa-Kalapana road.

At $3^{\text {h }}$ Myron Isherwood reported the outbreak of another fountain at vent $\mathrm{Y}$ ( $\mathrm{pl} .1$ and fig. 16). At $8^{\mathrm{h}} 20^{\mathrm{m}}$ the main fountain jet at vent $\mathrm{W}$ was playing to a height of 200 to 300 feet, with smaller jets 50 to 
100 feet high on its east-northeast and west-southwest sides. The main fountain at vent $\mathrm{Y}$ was 75 feet high, with smaller fountains on both sides of it. Vent $T$ continued quiescent except for heavy fume liberation.

At $16^{\text {h }}$ a violent earthquake occurred in the Kilauea caldera area, cracking highway pavement and breaking water pipes. This quake, part of a numerous series accompanying a sinking of the summit region of Kilauea, is described in another section of the report.

At $17^{\mathrm{h}} 30^{\mathrm{m}}$ Captain Bohlin reported from the air that a line of 4 fountains was playing to a height of about 200 feet at vent $W$, with a line of 5 or 6 smaller fountains 200 feet farther southwest (at vent Y). Two streams of lava poured southeastward from vent W, merging just upslope from the Pahoa-Kalapana road. About 1 mile farther southeast the flow again split into two very active tongues. The front of the more northerly tongue was a little more than 1 mile from the coast, near the south side of the earlier flow from vent $T$, and that of the more southerly tongue was only 3,700 feet from the coast.

Activity continued about the same through the rest of the day and the next morning, with the two flow fronts advancing about 150 to 250 feet per hour through the dense forest.

March 28.-At $7^{\mathrm{n}} 30^{\mathrm{m}}$ the main fountains at vent $\mathrm{W}$ continued to play to heights of 150 to 200 feet, and a large volume of lava was pouring southeastward into the flows. The activity at vent $\mathrm{Y}$ was reduced to a single small fountain. Vent $T$ showed no lava activity but was liberating dense clouds of white sulfurous fume.

At approximately $10^{\text {h }}$ the more northerly of the two fingers of the lava flow from vent $W$ entered the cleared land of the Yamada coffee -plantation, and the speed of advance of the flow front increased. At $12^{\mathrm{h}}$ the flow front was 600 feet from the ocean and was advancing at a rate of approximately 600 feet per hour. The flow was aa, and its advancing front was 10 to 15 feet high (fig. 17). The brightly incandescent pasty interior portion, that gives the flow its mobility, was clearly exposed in the rapidly moving front. The upper part of the flow moved more rapidly than the base, and the advance of the front was accomplished with a rolling motion resembling that of the front end of the endless track on a tractor or tank. Chilled black clinker from the upper part of the front rolled down and was overridden by the.red pasty layer.

Piles of loose rubbish 10 to 15 feet high, consisting of rocks and vegetation pushed up by bulldozers in clearing the land, stood in the path of the flow. The lava moved around and between the piles, burning the vegetable debris and eventually completely burying them, but without displacing them much. 


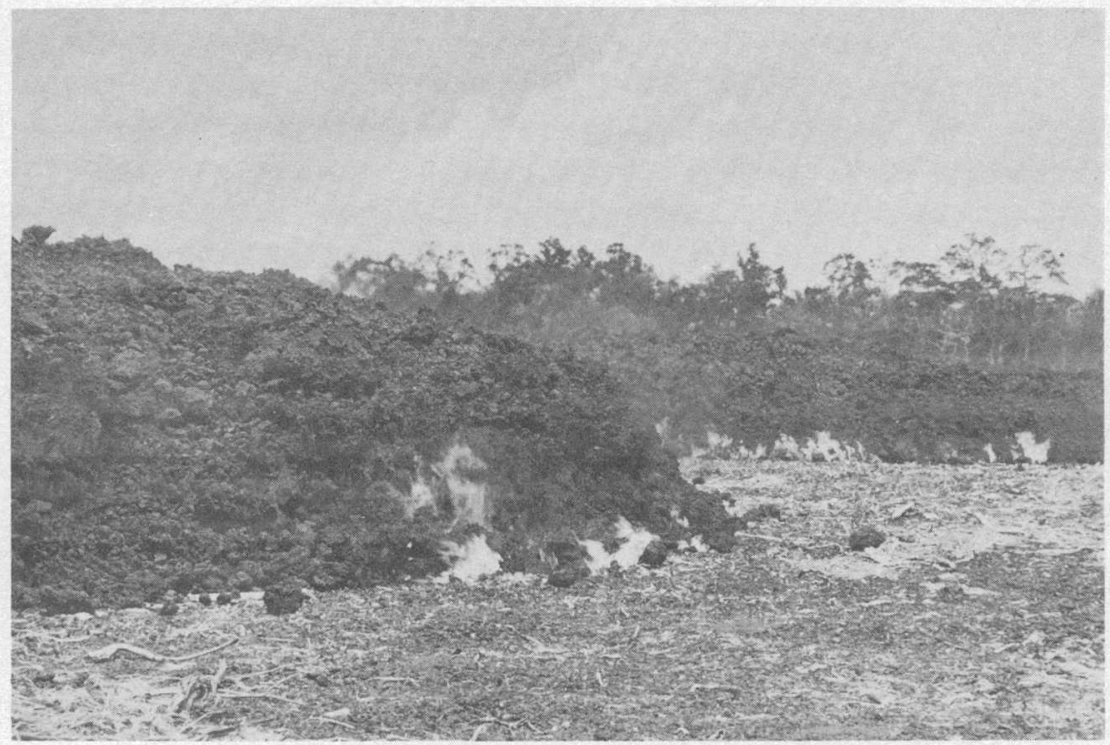

Figure 17.-Aa flow margin, about 15 feet high, advancing through cleared land near the coast at $12^{\mathrm{h}}$ on March 28. Flames along the edge of the fiow are from burning vegetation.

At $13^{\mathrm{h}} 18^{\mathrm{m}}$ the flow started to pour over the 50 -foot cliff into the ocean. Great billowing clouds of white steam obscured exceptmomentarily the growing heap of lava at the foot of the cliff (fig. 18). As the flow continued over the ocean floor, the base of the steam cloud expanded seaward. The cloud rose in billows to a height of several thousand feet, then was blown off to the southwestward. Along the edge of the base of the steam cloud (and possibly also in the central part, where vision was obscured) many small littoral explosions occurred (fig. 20). These explosions, caused by rapid generation of steam where water had found ingress to the hot interior of the flow, threw up columns of black ash-laden steam to heights of 50 to 100 feet. The black columns were very conspicuous against the white steam of the rest of the cloud. Individual explosions were not single puffs, but pulsating jets that continued for several seconds or minutes. No really long-continued littoral explosion jets were established, and consequently no littoral ash cone was built, but small deposits of black littoral ash and cinder accumulated on the surface of the flow and washed up along the adjacent coast to form small black sand beaches. Hot water was drifted northward along shore by currents.

At $17^{\mathrm{h}} 36^{\mathrm{m}}$ the more southerly tongue of the flow also entered the ocean, and again a great cloud of steam arose. As twilight advanced, 
the littoral explosions that had appeared so black in daylight were seen to glow bright red from the shower of incandescent ash. The flow continued to pour into the ocean throughout the night, but with gradually diminishing volume.

This flow was named the Keekee flow ( $\mathrm{pl} .1$ ) because much of it lay within the Keekee land division.

Weak activity continued through the night at vent $\mathrm{Y}$, and a flow from that vent crept seaward along the south side of the flows from vent $W$.

March 29.-At $4^{\mathrm{h}} 30^{\mathrm{m}}$ the pilot of a Hawaiian Airlines plane reported a new outbreak southwest of vent $W$ but northeast of vent U. This was probably the vent about 700 feet southwest of vent $\mathrm{Y}$ (pl. 1). Little is known of that vent other than that its activity was very short lived. It produced a flow of pahoehoe that extended seaward only about 500 feet from the row of small spatter cones that were built along the eruptive fissure.

At $9^{\text {h }}$ Barbara Rackle and Claude Jendrusch, of Honolulu, reported that the flow of lava into the sea had stopped. At $9^{\mathrm{h}} 30^{\mathrm{m}}$ the main fountain at vent $Y$ was playing to heights of 150 to 200 feet, and four or five small fountains lay along the fissure adjacent to it. A small flow was issuing from a breach in the east side of the cinder and spatter cone and turning southeastward. The front of the flow was

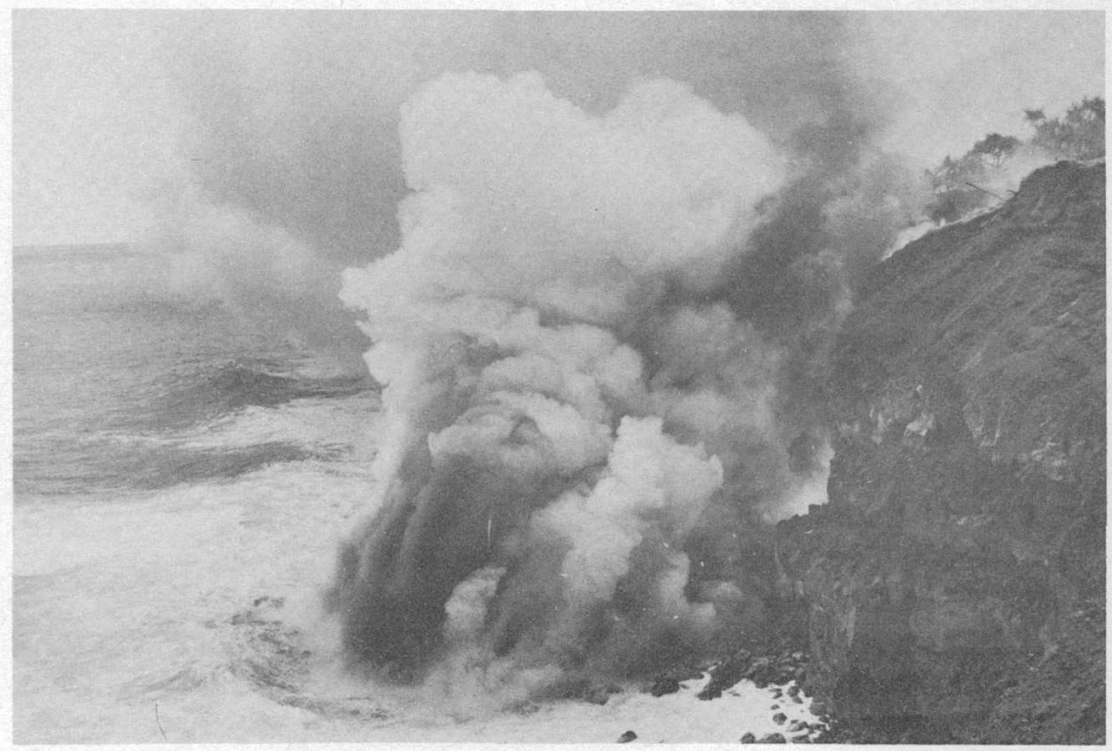

Figure 18.- Lava flow pouring over a 50-foot cliff into the ocean at $13^{\mathrm{h}} 25^{\mathrm{m}}$ on March 28 . Clouds of steam rise from the boiling water at the base of the cliff. 
about half a mile from the vent. No activity other than fume liberation was visible at vents $\mathrm{T}$ or $\mathrm{W}$.

Conditions remained about the same throughout the rest of the day. The new flow from vent $\mathrm{Y}$ continued to advance southeastward.

March 30.-Some time during the early morning hours activity resumed at vent $T$. At $9^{\text {h }}$ the main fountain at vent $T$ was playing to a height of about 25 feet, and a 10 -foot fountain was playing at the Blowhole vent, on the northeast side of the main cone. A small flow of pahoehoe was spreading eastward from the Blowhole vent. The fountain at vent $\mathrm{Y}$ continued to play to a height of about 200 feet (fig. 19), and the flow continued to advance southeastward from it. There was no lava activity at vent $W$, but a bright glow in the throat of the cone was visible from the air.

Through the morning the fountain at vent $\mathrm{T}$ continued to grow in size, and at $11^{\mathrm{h}} 15^{\mathrm{m}}$ Albert Kudo, Civil Defense warden, reported it to be about 200 feet high. Shortly after noon activity at vent $T$ died down rapidly, and at $13^{\mathrm{h}} 30^{\mathrm{m}}$ no lava activity was visible. A loud roaring of escaping gas was audible, apparently originating at the Blowhole vent. By $13^{\mathrm{h}} 50^{\mathrm{m}}$, however, activity had resumed, with fountaining both in the main cone and in the Blowhole vent. Lava flowed southeastward, partly over the older flows and partly over kipukas between them. At $15^{\text {h }}$ the main vent was throwing scattered bursts of cinder

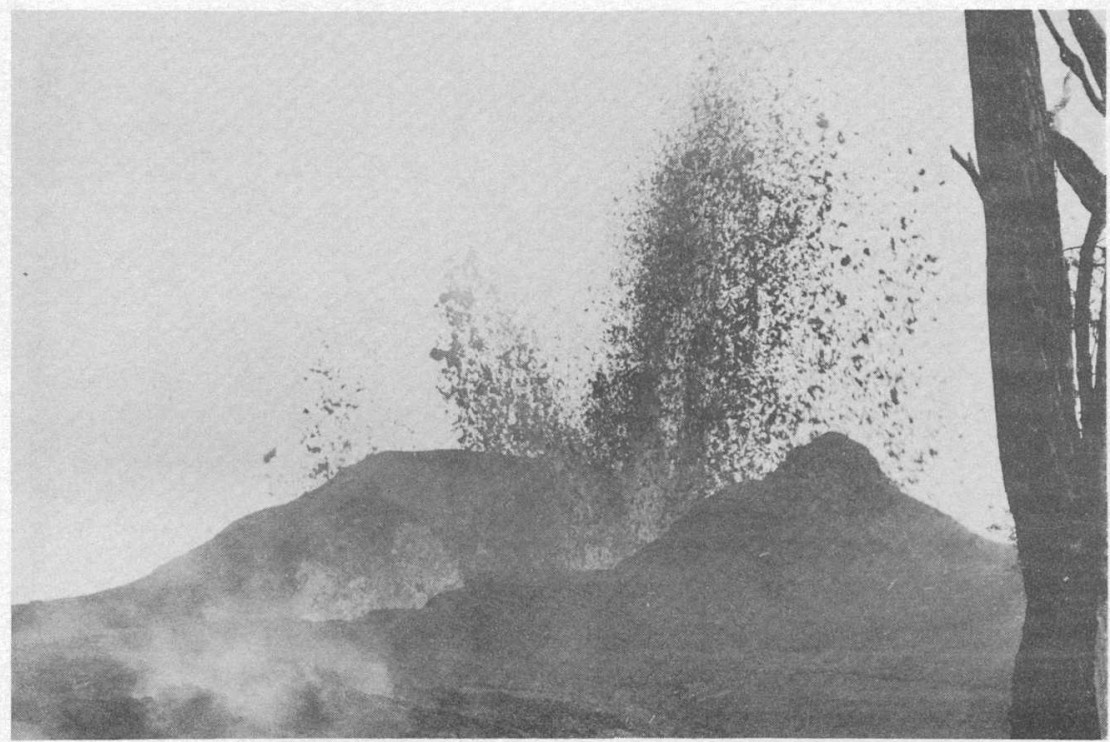

FigURD 19.-Lava fountain about 200 feet high playing in a cinder and spatter cone at vent $\mathrm{Y}$ (pl. 1) about noon on March 30. A smaller inclined lava jet shoots to the left at the base of the main fountain. 
to a height of 150 feet. Lava discharge had virtually ceased, however.

Conditions remained about the same:through the night, with the fountain at vent $Y$ playing to about 200 feet and lava continuing to spill southeastward from it. Conditions at vent $\mathbf{T}$.were variable, with fountaining and lava discharge taking place intermittently.

March 31.-At $8^{\mathrm{h}} 15^{\mathrm{m}}$ Sgt. Teruo Morigaki, of the Hawaii Police Department, reported that the Blowhole vent, on the northeast side of the cone at vent $T$, again became very active, with a lava fountain playing to a height of about 100 feet and a flow of lava spreading eastward from the base of the cone.

At $9^{\mathrm{h}} 30^{\mathrm{m}}$, Captain Bohlin reported that two small fountains were playing at ven't $\mathrm{T}$ and the Blowhole. At vent $\mathrm{Y}$ a fountain was playing steadily to 200 feet, with occasional bursts reaching a height of 500 feet. Most of the lava from vent $\mathrm{Y}$ was pouring eastward and northeastward, forming a pool north and northwest of cones $\mathrm{Y}$. and $\mathrm{W}$, and partly burying cone W.

During the morning, distension of the rift zone in the section between vents $T$ and $R$ resulted in minor graben collapse, forming fault scraps up to 1 foot high across the Pahoa-Kalapana road just south of the flows from vent $R_{6}$ and a trench 10 feet wide and about 10 feet deep across a trail a quarter of a mile farther west. . The collapse followed the base of an ..old fault scarp. Steam issued from the collapsed areas, but no sulfur odor ' was detected.

Activity at vent $Y$ continued about the same through the afternoon and night, with the fountain reaching heights as great as 650 feet as measured with an airplane altimeter. The lava discharged was small in amount, and formed pools around the cone.

In contrast, the two fountains at vent $T$ were of small size; but the lava discharge was great. . Throughout the morning and early afternoon the pool of lava northeast and east of cone $W$ had been increasing in area and particularly in depth. Occasional overflows of the pool sent flow tongues southeastward, and just before noon one such tongue crossed the Pahoa-Kalapana road before becoming stagnant. About noon a major overflow commenced and sent a rapid flow southeastward toward the Iwasaki Camp. By $13^{\mathrm{h}}$ the flow had crossed the road, and a very fluid aa front 4 feet high was advancing toward the camp at a rate of about 2,000 feet per hour. A coffee plantation near the road had been partly destroyed. Violent explosions, caused by the ignition of hydrocarbon gases derived from vegetation buried by the lava, occurred at the edge of the flow and up to 50 feet away from it. These explosions threw rocks up to 6 inches in diameter as far as 25 feet and produced craters up to 3 or 4 feet in diameter and 2 to 3 feet in depth. 
By $14^{\mathrm{h}}$ the flow front was advancing through canefields less than half a mile from the Iwasaki Camp, but activity at the vent had started to diminish. At $14^{\mathrm{h}} 30^{\mathrm{m}}$ the advance of the flow front had slowed greatly, and the speed of flow in the main feeding river at the Pahoa-Kalapana road was only about 5 feet per minute. At $14^{\mathrm{h}} 40^{\mathrm{m}}$ lava discharge at the vent had stopped, and the fountain was very weak. At $15^{\mathrm{h}}$ there was no further movement of lava in the feeding river at the road, and the front of the flow had stagnated about 2,000 feet from the Iwasaki Camp.

At $16^{\mathrm{h}} 35^{\mathrm{m}}$ there was a bright glow and weak blowing of cinder at the Blowhole vent but no lava discharge. This condition continued through the night.

During the afternoon, a report of eruption at the summit of Mauna Loa proved false.

A pril 1.-At $5^{\mathrm{h}} 15^{\mathrm{m}}$ the Blowhole, in vent area $\mathrm{T}$, showed no activity other than dense fume liberation, and pale flames several feet long played above the lip of the cone. The main vent $T$ was inactive. At $11^{\mathrm{h}} 50^{\mathrm{m}}$ the Blowhole was still inactive, but weak lava fountaining and bubbling lava were present in the main vent. At $18^{\mathrm{h}} 15^{\mathrm{m}}$ the Blowhole vent started throwing up weak showers of cinder, and at $19^{\mathrm{h}} 25^{\mathrm{m}}$ lava started flowing northeastward from the base of the cone. This condition continued through the night, with the lava forming a pool on top of the older flows to the northeast and east of the cone. At about $20^{\mathrm{h}}$ a new vent appeared between the Blowhole and the main vent, and either one or two small lava fountains were active there throughout the night.

At $8^{\mathrm{n}} 30^{\mathrm{m}}$ the lava fountain at vent $Y$ was about 200 feet high, and lava had again started to spill southeastward into the flow that lay along the southern edge of the Keekee flow. This flow had started on the evening of March 27, but it had been nearly stagnant on March 31 when most of the lava from the vent had been flowing into the pool northeast of the cone. Resumption of lava discharge to the southeast reactivated the flow. At $11^{\mathrm{h}} 50^{\mathrm{m}}$ the flow front was approximately 0.8 mile from the sea. Conditions at vent $\mathrm{Y}$ remained the same through the night, and the lava flow continued to advance slowly.

April 2.-At $7^{\mathrm{h}}$ the Blowhole, in vent area $\mathrm{T}$, was fountaining to a height of about 50 feet, with occasional bursts reaching 100 feet. No lava discharge from the vent was visible, and the ejecta were large clots of spatter rather poor in gas. No activity was visible at the main vent $\mathrm{T}$ or at the small vents between it and the Blowhole. At $13^{\mathrm{h}} 10^{\mathrm{m}}$ only fume liberation was visible at the main vent $T$, and the Blowhole was discharging occasional showers of fine cinder. This condition continued for the rest of the afternoon and night. 
At $11^{\mathrm{h}}$ the fountain at vent $Y$ was still about 200 feet high, and lava continued to discharge southeastward. The front of the flow was 1,500 feet from the ocean, about 10 feet high, and advancing about 100 feet per hour. During the afternoon the rate of advance of the flow front increased. At about $18^{\mathrm{h}}$ the lava destroyed two houses and most of the coconut grove at Kehena, and at $18^{\mathrm{h}} 29^{\mathrm{m}}$ it went over the sea cliff into the ocean. The same phenomena were observed as during the entrance of the Keekee flow into the sea on March 28. This flow has been named the Kehena flow because it reached the ocean through the Kehena lands.

Activity at vent $\mathrm{Y}$ and in the Kehena flow remained the same through the night.

A pril 3.-At $7^{\mathrm{h}} 30^{\mathrm{m}}$ the crater in the Blowhole cone was seen from the air to be 100 to 150 feet deep, with glowing red walls and a pool of bubbling lava at the bottom. There was no fountain activity either at the Blowhole or at the main vent $\mathrm{T}$. At vent $\mathrm{Y}$ a lava fountain was playing to a height of about 150 feet, and lava was flowing southeastward to feed the Kehena flow. Just inland from the coast, the flow divided into two fingers. Both fingers were pouring over the sea cliff (fig. 20), but the one to the northeast was much more active. Conditions remained about the same through the rest of the day, with the

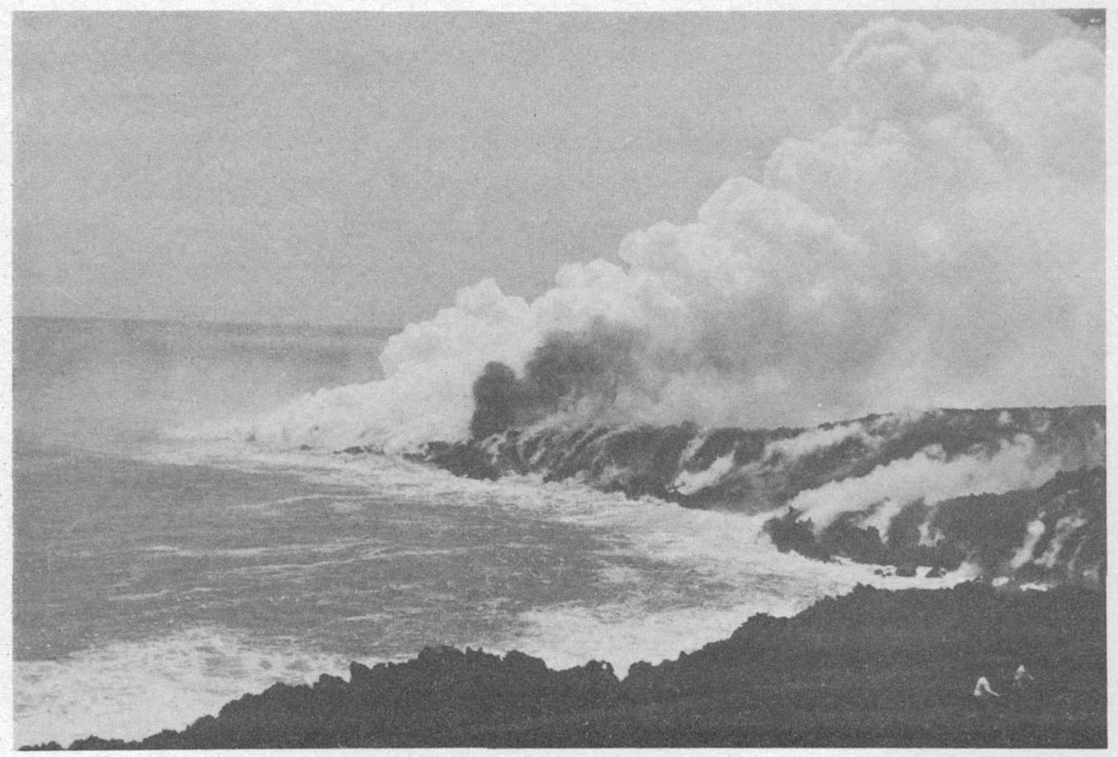

Figure 20.-The steaming toe of the Kehena lava flow in the ocean, about $10^{\mathrm{h}} 30^{\mathrm{m}}$ on' April 3. The flow built a peninsula that extended about 800 feet beyond the former shoreline. In front of the white main steam column a black jet of ash-laden steam 1s being thrown up by a littoral explosion. 
size of the fountain at the vent gradually diminishing. During midafternoon cinders were ejected for a short time from the Blowhole in vent area $\mathrm{T}$. During the night pale-blue flames were observed in the area near the pit crater and along the road in vent area $R$.

A pril 4.- The main vent in area $\mathrm{T}$ ejected occasional weak bursts of cinder for a short period around midnight; but by daylight no further activity was visible in that area. At $9^{\mathrm{h}} 50^{\mathrm{m}}$. the fountain at vent $\mathrm{Y}$ was 50 to 100 feet in height; and lava continued to flow southeastward into the sea. A lava delta several hundred feet across had been built in front of the old sea cliff. Activity continued about the same throughout the day.

A pril 5.-At $10^{\mathrm{h}}$ the fountain at vent $\mathrm{Y}$ was playing to a height of about 200 feet above the cone. The cone was about 100 feet high, and lava continued to pour southeastward from it into the ocean. No lava activity was visible in the vent $\mathrm{T}$ area. By $14^{\mathrm{h}}$ both the main cone $\mathrm{T}$ and the smaller cone at the Blowhole had partly collapsed. Activity at vent $\mathrm{Y}$ continued about the same throughout the rest of the day and night. Lava flowed eastward from the breached cone through a partly roofed over channel, then turned abruptly southeastward. Throughout most of the distance to the sea the lava moved through a single narrow channel near the middle of the broad field of black nearly stagnant aa lava. In some places the feeding river divided, only to reunite again like a braided stream. The river ranged from about 15 to 50 feet wide. As the supply of lava varied, at times the channel was full to overflowing, and at other times the surface of the liquid dropped as much as 10 feet below the level of the banks. Large amounts of lava continued to enter the sea, and a billowing column of steam rose high into the air. Very numerous littoral explosions occurred, but all were small and short lived.

April 6.-At $9^{\text {h }}$ aerial observation showed the fountain at vent $\mathbf{Y}$ to be 50 to 100 feet.high, playing through a pool of molten lava in the crater of the cone. Lava escaped from the crater by plunging into a tube on the east side, from which it emerged about 50 feet downslope and continued seaward in an open river. Two tongues of lava were moving into the ocean. Conditions remained the same throughout the morning. At $13^{\text {b }}$ the fountain was still reaching heights of about 100 feet above the rim of the cone. At $13^{\mathrm{h}} 50^{\mathrm{m}}$ Koji Iwasaki, a local cane grower, reported that the fountain was inactive. At $14^{\mathrm{h}} 20^{\mathrm{m}}$ this was confirmed from the air by Captain Bohlin, who reported the fountain dead, lava extrusion ceased, and the cone starting to cave in. Bohlin continued to watch the area from the air, and at $15^{\mathrm{h}} 15^{\mathrm{m}}$ observed weak fountaining resuming in the crater of the cone, and lava 
again pouring down the channel. At $16^{\mathrm{h}} 15^{\mathrm{m}}$ a sluggish stream of lava was moving through the feeding channel of the flow. At a point about half a mile below the vent, the rate of movement was approximately 150 feet per minute on a slope of $5^{\circ}$.

At $18^{\mathrm{h}}$ activity at vent $\mathrm{Y}$ had again ceased, and only red glowing sparks were visible in the crater of the cone from the air. Activity resumed at $18^{\mathrm{h}} 35^{\mathrm{m}}$, however, with fountaining 100 to 150 feet high. At $21^{\text {h }}$ Albert Wilson, Civil Defense warden, reported the fountain to be low, but a large volume of lava was pouring out and flooding over the entire area east and southeast of the cone. By $22^{\mathrm{h}} 50^{\mathrm{m}}$ the fountain rose 150 feet above the rim of the cone, and lava was again pouring through the feeding channels of the Kehena flow as well as feeding a new flow that was advancing along the south edge of the older flow.

April \%.-Activity at vent $\mathrm{Y}$ continued unchanged through the morning. At $1^{\mathrm{h}} 15^{\mathrm{m}}$ the front of the new flow was 1,200 feet southeast of the former Pahoa-Kalapana road and advancing very rapidly. By $11^{\mathrm{h}} 50^{\mathrm{m}}$ it was only half a mile from the ocean. During the next 3 hours it advanced 0.2 mile. At $14^{\mathrm{h}} 30^{\mathrm{m}}$ the lava fountain was about 100 feet high. However, at about $14^{\mathrm{h}} 40^{\mathrm{m}}$ the lava fountaining ceased, and shortly afterward the flow slowed down greatly. At $16^{\mathrm{h}}$ Albert Kudo, Civil Defense warden, reported the vent again active, throwing showers of cinder to a height of 100 feet, but by $18^{\mathrm{h}} 30^{\mathrm{m}}$ activity had again ceased. No further fountain activity was observed during the night, and by morning the lava flows also were completely inactive.

During the afternoon a brightly glowing hole was reported in the lava flows at the site of a former coffee plantation about a quarter of a mile northeast of vent $T$. Investigation showed a low mound of lava where the flow had overwhelmed a pile of brush heaped up in clearing the land. At the top of the mound a tongue of flame 5 feet long played over a hole 4 feet in diameter. The interior of this ruptured lava blister was glowing a bright incandescent orange, heated by combustion of the gases distilled from the buried rubbish.

\section{QUIET PERIOD-APRIL 8 TO 28}

No lava activity was visible anywhere in the area during the period from April 8 to April 23. Moderate to light fuming continued at vents $\mathrm{T}$ and $\mathrm{Y}$, and steaming continued at many of the earlier vents, especially those at $\mathrm{M}$ (pl. 1$)$.

On April 9, Captain Bohlin reported from the air the presence of a brightly glowing nearly circular hole, 20 feet in diameter, about 250 feet northeast of the base of the cone at vent $Y\left(Z\right.$, pl. $1 ; Z_{1}$, fig. 16). Investigation on the ground showed this to be a tubelike open- 
ing, sloping toward the adjacent cone at an angle of about $75^{\circ}$. The opening enlarged slightly downward, and the walls were brightly incandescent. The pit was first observed at $17^{\mathrm{h}}$. At $16^{\mathrm{h}} 30^{\mathrm{m}}$ workers in the control tower at Hilo airport observed a large puff of black smoke at about the position of this new pit. This puff may have been caused by an explosion that destroyed the roof of the pit. For the next several nights long tongues of gas flame were seen from time to time over the mouth of the pit. In many respects this pit resembled the somewhat:larger pit crater formed at vent $R_{5}$. on March 20 .

On April 10 and again on April 21 loud rumbling sounds were heand in the vicinity of vent $\mathrm{Y}$. A bright glow was seen in the crater of the cone at $\mathrm{Y}$ on the evening of April 10, but no other activity was visible.

\section{FINAL PHASE-APRIL Q4 TO MAT 96}

April 24.-At about $15^{\mathrm{b}}$ on April 24, two visitors at vent $\mathbf{T}$ found very weak lava activity in progress on the west-northwest side of the crater (fig. 16). This activity built a spatter conelet 3 feet high and sent a flow of pahoehoe about 50 feet long down the slope toward the bottom of the crater. It apparently lasted only a very few hours.

A pril 25.-No activity was reported anywhere in the area.

April 26.-During the morning the small pit at $Z_{1}$ (fig. 16), just northeast of cone $Y$, was puffing loudly on an average of once every 4 seconds. Some of the puffs were strong enough to blow fragments of rock up to an inch in diameter to a height of about 15 feet. The ejecta were fragments of previously consolidated material torn from the walls of the pit by the gas blasts. The pit was plugged with spinose aa lava at a level 10 feet below the rim. This.lava had risen in the pit within the preceding few days. A brightly glowing crack 1 to 3 feet wide lay between the lava plug and the wall of the pit on the southwest side, extending irregularly downward and back toward cone $\mathrm{Y}$ for an indeterminable distance. The gas blasts appeared to be issuing from the crack.

About 200 feet northeast of the pit the eruptive fissure exposed part of the wall of the cinder cone of vent W. At the end of lava extrusion from vent $\mathrm{Y}$ collapse along the fissure formed a wedge-shaped graben about 60 feet long, 30 feet wide, and 25 feet deep. Weak explosions from the fissure at the base of this graben had thrown a thin layer of fine cinder over the adjacent lavas. The cinder was torn from the buried portion of the cone. This explosion, like the rise of lava in the pit, must have taken place.within the preceding few days.

At $12^{\mathrm{h}} 10^{\mathrm{m}}$ Macdonald heard a puffing noise, not previously present, coming from the vicinity of vent $T$. Investigation at $12^{\mathrm{h}} 20^{\mathrm{m}}$ revealed a small active vent on the south-southwest side of the crater of cone $T$ 
(fig. 16). The vent was throwing bursts of spatter to a height of 10 or 15 feet every few seconds, with occasional bursts of scattered ejecta reaching heights of 50 to 75 feet. During the next 2 hours a spatter conelet 4 feet high was built, and a flow of pahoehoe spread around the vent and sent a tongue northeastward into the bottom of the crater bowl. At $13^{\mathrm{h}}$ the flow was 50 feet long and averaged about 7 feet wide. By $15^{\mathrm{h}} 30^{\mathrm{m}}$ activity had ceased; but at $16^{\mathrm{h}}$ it had started again, with sparse showers of spatter occasionally reaching a height of 10 feet, and rarely as much as 30 feet. No sign of lava extrusion could be seen. This condition continued, probably intermittently, through the night and the next day.

April 2\%.-During the early afternoon loud rumbling noises were heard by Albert Wilson at vent $Y$. The pit just northeast of the cone was fuming heavily. At $18^{\mathrm{h}} 30^{\mathrm{m}}$, Reginald Ho of Pahoa reported a new flow of pahoehoe about 600 feet east of vent $T$. The lava issued quietly, without spattering, from a fissure in flows poured out in late March and was advancing about 200 feet per hour over the surface of the older flow. The speed of advance soon slowed, however.

A pril 28.-At $10^{\mathrm{h}}$ the new flow east of cone $\mathrm{T}$ was reported by Myron Isherwood to be about 1,000 feet long and up to 400 feet wide. Viscous pahoehoe was still oozing from the vent, and the toe of the flow was creeping forward at only a few feet per hour. At $10^{\mathrm{h}} 15^{\mathrm{m}}$ several loud explosions in the crater of the cone at vent $T$ threw showers of cinder and possibly rock fragments 100 feet in the air. The material appeared to be solid, and no incandescence was observed. At about $10^{\mathrm{h}} 45^{\mathrm{m}}$ other similar explosions were heard, but no cinder ejections could be seen. The vent was hidden from view by the cone wall, however, and small ejections may have occurred.

During the afternoon the flow was much the same as reported in the morning. There was no evidence that the lava had issued from a tube in the earlier flow, as previously had been supposed. Instead, the lava appears to have been intruded beneath the surface of the earlier flows, lifting them somewhat, in a manner similar to the formation of pressure plateaus (Wentworth and Macdonald, 1953, p. 49). The vent was simply a place where the overlying lavas had been bulged up and split open. The earliest lava extruded on April 27 was ordinary-appearing, moderately dense pahoehoe. The later lava was unusually dense, poor in gas, and formed heaps of entrail lava in places. Very sluggish movement of toes at the end and edges of the flow still continued (fig. 21). Heavy rain on the bright red surfaces of rapidly swelling toes had no apparent effect on the lava. Later sampling revealed no thick layer of tachylite on the surface, although the usual thin glassy skin was present. 


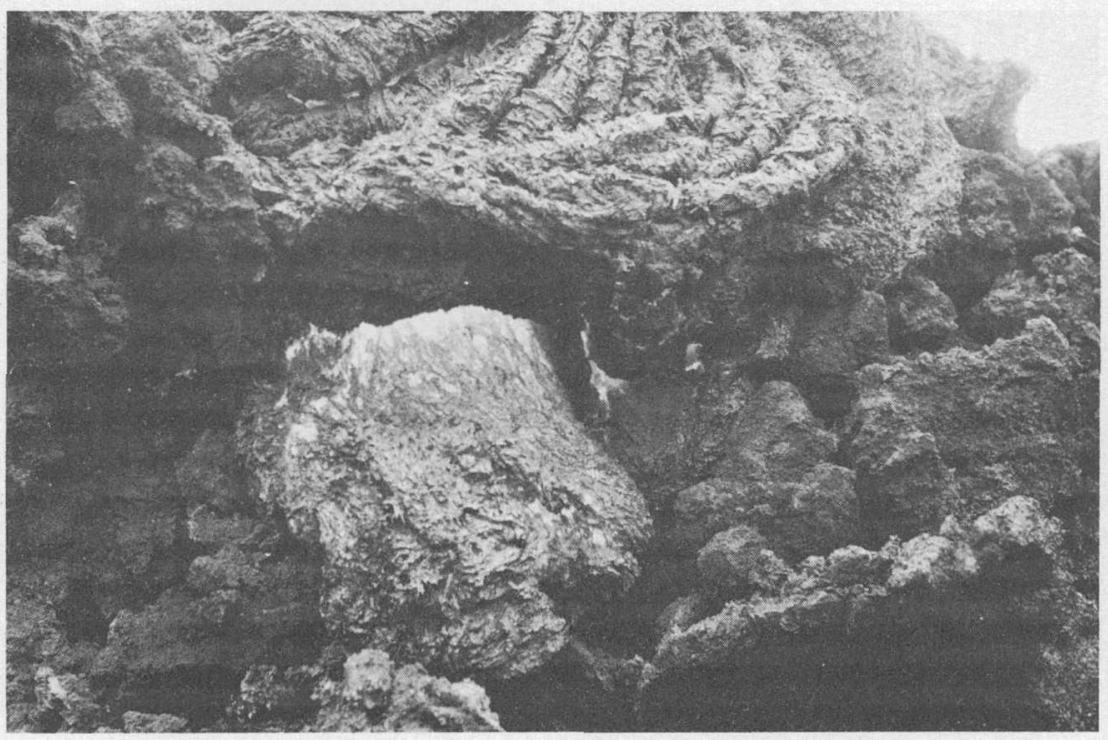

Figure 21.-Pahoehoe tongue being squeezed out from beneath a slightly older ropy pahoehoe crust, on the small flow of dense pahoehoe east of cone $T$ (pl. 1) on the afternoon of April 28. The tongue is about 1 foot long and brightly incandescent.

The vent that produced the explosions at $10^{\mathrm{h}} 15^{\mathrm{m}}$ and $10^{\mathrm{h}} 45^{\mathrm{m}}$ was located on the south side of the crater of the cone, just northeast of the spatter conelet of April 26. It was an old cinder mound that formed during the activity prior to April 4 but had been covered since A pril 26 with black clots of fresh spatter. Many fragments of cinder lay on and around the mound, some of them on top of the black spatter. The cinder was old, apparently torn from the walls of the vent by the blasts of gas. In midafternoon the walls of the vent were still glowing a dull red.

A prit 29.-No surface lava activity was present anywhere in the area. Vents $\mathrm{T}$ and $\mathrm{Y}$ and the pit at $\mathrm{Z}$ all continued to fume.

A pril 30.-During the early morning hours there were no signs of lava activity, but in midmorning sporadic cinder ejection resumed in the crater of the cone at vent $\mathrm{T}$, occasional bursts reaching heights of 100 to 150 feet. There was no sign of lava flow either in the crater or east of the cone.

About $11^{\mathrm{h}}$ Albert Kudo observed the beginning of activity at the small pit at $Z_{1}$ (fig. 16), just northeast of cone $Y$. Showers of spatter reached a height of 50 feet, with occasional bursts reaching 150 to 200 feet. One finger of a pahoehoe flow started down the old channel of the earlier Kehena flow, and another moved northeastward into the partly collapsed crater of cone W. 
At $14^{\mathrm{h}} 45^{\mathrm{m}}$ there were two active vents on a northeast-southwest line, about 50 feet apart, approximately over the site of the small pit. Pahoehoe flows had built a shield-shaped mound of lava around the vents, at the summit of which were two spatter conelets 10 and 15 feet high. A flow of pahoehoe from the southwestern vent had spilled into the old channel of the Kehena flow. Where it tumbled down the 20foot cliff at the side of the channel the flow had changed to aa. The southwestern vent was throwing showers of spatter to heights of about 150 feet, but lava no longer isued from it. The northeastern vent was liberating a stream of pahoehoe (fig. 22). For the most part the lava spilled gently over the lip of the conelet in a series of surges, but occasional explosive bursts covered the entire outside of the conelet with fluid red spatter. These explosive episodes appeared to be merely the bursting of big bubbles. During each, a regular domeshaped mass of liquid lava was heaved up, and then torn apart by expansion of gas within it. For a brief moment the liquid clots in the air retained approximately the hemispherical form of the dome, then flew apart and fell to the ground. A puff of brown gas rose above the broken bubble.

During the late afternoon and evening very weak activity continued in the crater of cone $\mathrm{T}$, with scattered bursts of spatter from the vent

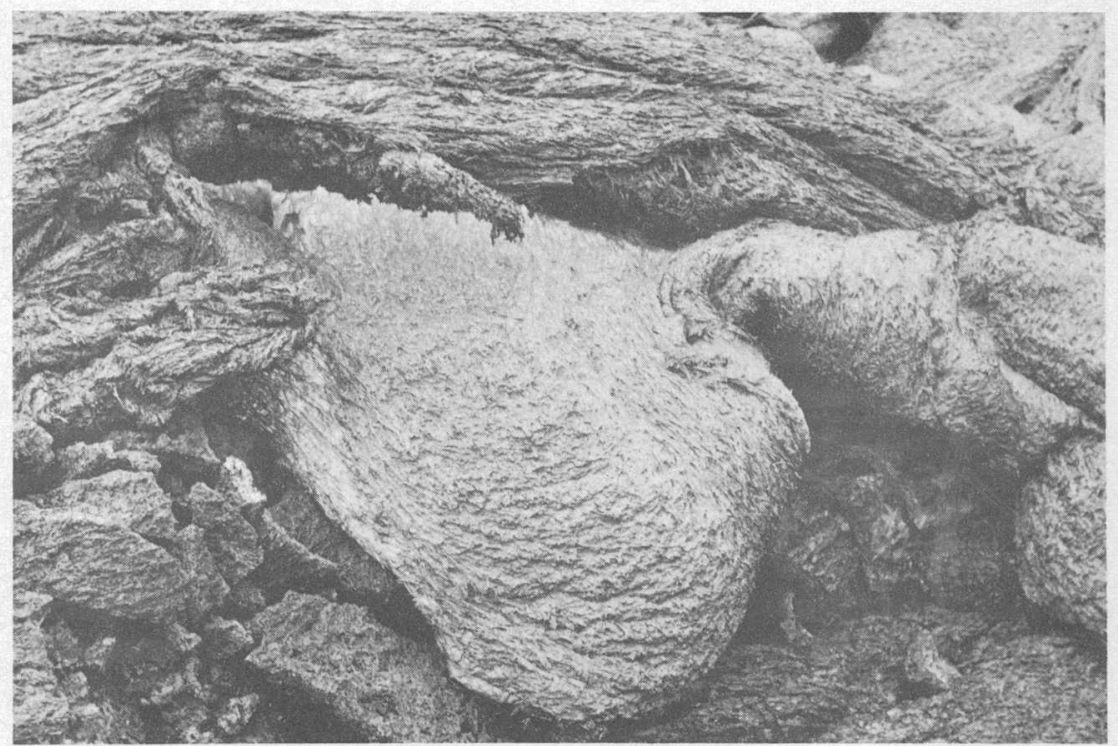

Figure 22.-Brightly incandescent tongue of pahoehoe, about 2 feet long, being squeezed out of a fracture in the crust of a small pahoehoe flow on the northeast side of the spatter conelets at vent $Z$ (pl. 1) on the afternoon of April 30. 
that had been active on April 26 reaching heights of about 10 feet. No lava outflow was taking place in the vent $T$ area.

During the night lava outflow at vent $Z$ ceased, but spatter ejection continued.

May 1.-Spatter ejection continued during the morning at vent area $Z$ and in the crater of cone $T$.

At $13^{\text {h }} 30^{\mathrm{m}}$ the southwestern vent at $Z$ was still active, throwing explosive bursts of liquid spatter to heights of 150 to 200 feet every 1.5 to 2 seconds. The spatter conelet had grown to a height of about 25 feet. The northeastern vent was inactive and largely buried by the spatter cone growing around the southwestern vent. No movement could be detected in any of the flows. Frequent small sharp earthquakes were felt by observers sitting on the ground, but not by those standing. The quakes did not appear to be related to the explosive bursts at the active vent.

At $14^{\mathrm{h}} 30^{\mathrm{m}}$ activity increased markedly in the crater of cone $\mathrm{T}$. The vent just northeast of that of April 26, which had produced the explosions on April 28, commenced throwing showers of red plastic spatter to a height of about 250 feet. The jet was inclined toward the .east, so that the ejecta struck the ground as much as 500 feet from the vent. On striking, the fluid ejecta flattened out to form cow-dung bombs, which for several seconds, remained pastic enough for coins to be pushed into.them.

Activity at both areas continued unchanged through the night.

May 2.-Activity at vent $Z$ remained about the same as on the previous afternoon. Activity continued in the crater of cone $\mathbf{T}$ also, but bursts of spatter were less frequent and less violent.

During the afternoon, outflow of lava resumed at vent $Z$, with pahoehoe spilling into the channel of the Kehena flow and moving slowly southeastward, changing into aa as it advanced. At $15^{\mathrm{h}} 15^{\mathrm{m}}$ the flow was about 600 feet long.

May 3.-Activity continued unchanged. By midafternoon the cone at vent $Z$ had grown to a height of about 75 feet, and explosive bursts of cinder and spatter were being thrown as much as 450 feet above the top of the cone approximately every 2 seconds. The cone consisted principally of loose cinder, but contained much spatter. Big blobs of spatter striking the upper part of the cone rolled down the sides, growing by accretion like rolling snowballs. The lava flow had advanced about 1,000 feet along the channel of the Kehena flow, but was nearly stagnant.

In the crater of cone $T$ a small explosive burst of cinder occurred about once every 15 minutes. 
May 4.-Activity at vent $Z$ continued the same, with showers of cinder almost constantly reaching heights of 100 to 150 feet above the cone. Two small pahoehoe flows were issuing quietly at the northeast base of the cone and flowing northeastward, filling the space between the base of cone $Z$ and the remnant of the north wall of cone $W$. No new lava reached more than 250 feet from the cone.

Occasional weak cinder ejections continued in the crater of cone $T$.

May 5.-Conditions at vent $\mathrm{Z}$ remained the same as on the previous day. The small pahoehoe flows northeast of the cone continued to be slightly active, and another flow broke out at the northwest base of the cone and flowed about 100 feet. All these flows were sluggish, composed of dense comparatively gas poor lava. There had been some addition of new lava beneath the surface of the slightly older lava in the channel of the Kehena flow, causing a bulging of the flow top for about 600 feet east of the base of the cone.

No activity was observed in the crater of cone $\mathrm{T}$ during the day. However, during the morning William Keliipio of the American Red Cross found a slight oozing of new lava at the toe of the flow of April $27-28$, east of cone $\mathrm{T}$.

May 6 and $\%$.-Activity at vent $Z$ continued unchanged with cinder ejection to heights of 50 to 150 feet and small flows of pahoehoe pooling around the base of the cone and spilling into the channel of the Kehena flow. No activity was observed in the vent $T$ area.

May 8.-Activity at vent $Z$ continued about the same.

East of the vent the surface of the Kehena flow formed a broad, nearly level plateaulike area, reflecting a flat in the preexisting topography. Beyond this was a steep slope to the southeastward, probably a fault scarp buried by lava flows. Early in May, lava appears to have been intruded beneath the surface layers of the Kehena flow in the plateau area. At the edge of the plateau, 1,200 feet east of cone $Y$, the surface of the Kehena flow was heaved up into a broad oval hump 10 to 15 feet high and about 200 feet long (fig. 16). The surface of the hump was highly cracked and fissured. During the morning of May 8 lava broke out from a fissure on the seaward side of the hump and flowed southeastward, spilling into the old channel of the Kehena flow and following it. Near its point of issue the lava was pahoehoe, but a short distance downslope it changed to aa. By $16^{\text {h }}$ the flow was about 2,000 feet long, and its front was approaching the former line of the Pahoa-Kalapana road. This flow continued through the night. By midnight its length was about 2,500 feet, but its speed of advance was decreasing.

May 9.-During the morning activity at vent $\mathrm{Z}$ continued unchanged. About $11^{\mathrm{h}}$ Albert Wilson observed the opening of a new 
vent ( $Z_{2}$, fig. 16) approximately 200 feet northeast of $Z_{1}$. Fluid spatter was thrown 100 feet into the air, and a spatter cone was rapidly built up. The earlier cone continued active, and lava flows continued to escape at its base (fig. 23). These flows issued quietly, without spattering, from beneath slightly overhanging lips on the base of the cinder cone. Near their sources they were pahoehoe, but they changed to aa a few tens of feet downstream. At $13^{\mathrm{h}} 30^{\mathrm{m}}$ a flow of this sort was spilling westward from the cone into a hollow. This flow was 6 feet wide, about 10 inches thick, and was pouring down a slope of $27^{\circ}$ at a rate of 1 foot per second. The temperature measured with a thermocouple in a similar small tongue was $930^{\circ} \mathrm{C}$. There appears to have been a partial separation of phases in the vent, with most of the gas escaping in the crater of the cone and giving rise to semiexplosive bursts of spatter, while the lava escaping quietly at the base of the cone was relatively poor in gas.

During the early afternoon a roaring gas vent was active on the new flows between the new conelet $\left(Z_{2}\right)$ and the older active cinder cone $\left(Z_{1}\right)$. At $14^{\mathrm{h}} 15^{\mathrm{m}}$ a blob of liquid lava appeared at the surface at this vent and spread out to form a subcircular cake about 1 foot thick and 8 to 10 feet across. After 2 or 3 minutes gas started to escape through the cake of viscous lava, throwing shreds of spatter into the air. The size of the jets gradually increased, until by $14^{\mathrm{h}} 25^{\mathrm{m}}$ they

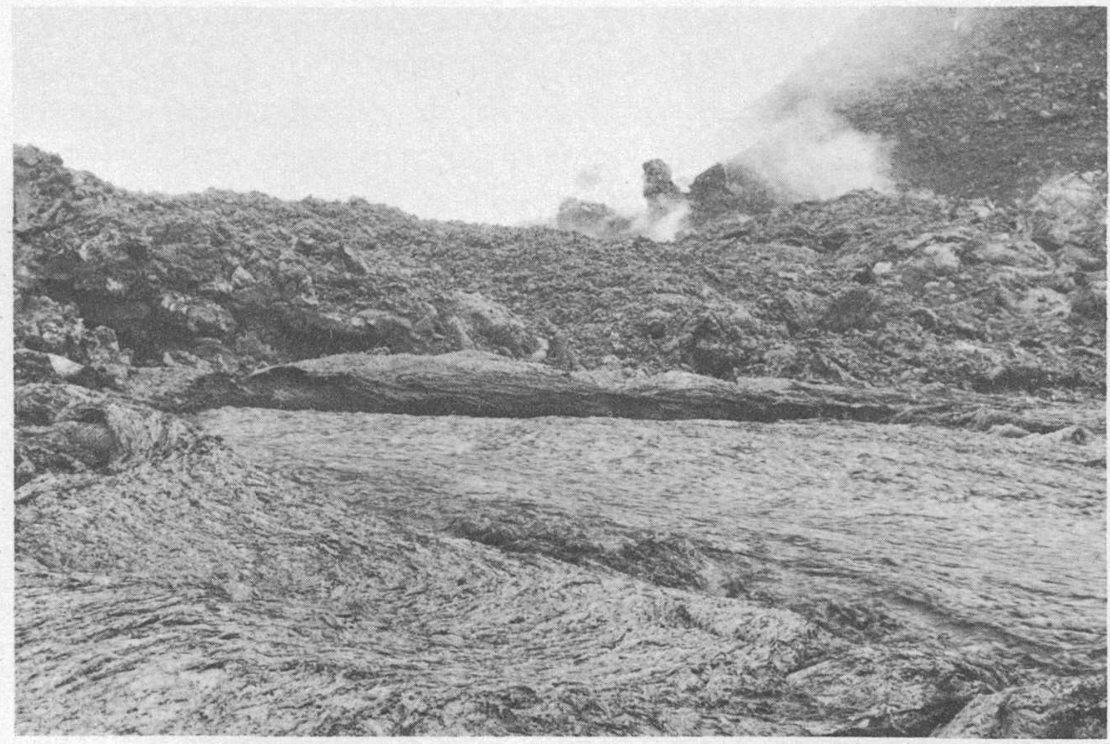

Figure 23.- - Lava issuing quietly at the base of the cinder cone at vent $\mathrm{Z}_{1}$ (fig. 16) at $13^{\mathrm{h}} 30^{\mathrm{m}}$ on May 9. At the head of the flow is an arcuate embankment 3 to 4 feet high and slightly overhanging. 
were reaching heights of 100 feet. A small flow of pahoehoe moved outward from the new vent. As activity at the new vent increased, that at the other two vents decreased. Through the rest of the afternoon and night all three vents continued active.

The flow issuing at the hump 1,200 feet east of the cones was still active on the afternoon of May 9, but had decreased greatly.

May 10.-Activity in vent area $Z$ continued unchanged, with three vents active. Lava continued to ooze out at the hump 1,200 feet east of the cones, but the front of the flow had ceased to advance.

May 11.-Activity continued unchanged through the day. By $22^{\mathrm{h}}$ cinder ejection at vent $Z_{3}$ had nearly ceased. Vent $Z_{1}$ was throwing showers of cinder to a height of 100 feet. Three small flows of lava were oozing from the base of cone $Z_{2}$ and pouring northward into a broad depression. Lava still oozed out 1,200 feet east of the cones, and two small new aa flow fronts were advancing over the earlier flows near the former position of the Pahoa-Kalapana road.

May 12.-Activity continued unchanged. All three vents in area $\mathbf{Z}$ were active, throwing explosive bursts of spatter to heights of about 200 feet every few seconds, with occasional fragments reaching more than 600 feet. The ejecta were incandescent plastic blobs of lava. The larger blobs descended with a loud whistling noise. Cone $Z_{1}$ was about 75 feet high, cone $Z_{2}$ about 15 feet, and cone $Z_{3}$ about 30 feet. During the preceding 2 days many small flows had spread around the base of the cones, building up the surface of the lava mound around the cones nearly to the level of the rim of cone W.

The heavier explosions caused a distinct shaking of the ground near the vents, and they may have been the cause of many tiny tremors recorded on the Pahoa seismograph. The noise of the explosions was clearly audible 1.5 miles away and occasionally as much as 5 miles away. The activity was bordering on Strombolian in type, clearly indicative of increased viscosity of the lava in the vents.

Small lava flows from the hump east of the cones continued to advance in the vicinity of the Pahoa-Kalapana road.

May 13-15.-Activity continued much the same. Vent $Z_{2}$ became inactive early on May 13, but the other two vents continued throwing showers of spatter to heights of 100 to 300 feet. The explosive bursts were very noisy. Only small amounts of lava oozed out at the base of the cones. Lava issuing from a tube partly filled the depression north of the cones. Small flows of lava issuing at the hump east of the cones continued to spread over older flows between the hump and the former Pahoa-Kalapana road. By the afternoon of May 15, the cone at vent $Z_{2}$ had been buried by the growing cone of $Z_{3}$. 
May 16.-During the morning the amount of lava being poured out in vent area $Z$ increased greatly, and the extruded lava became much more fluid. By midafternoon a pool nearly 1,000 feet. across had formed between cones $\mathrm{W}$ and $\mathrm{T}$, and lava was spilling southeastward out of the pool over the heads of the earlier Keekee and Kehena flows. The bases of the cones at $Z_{1}$ and $Z_{3}$ had merged to form one broad mound of intermingled lava flows and spatter, completely burying the remnants of cone W. From this mound rose the two conelets built around the active vents. That at $Z_{1}$ was a typical cinder and spatter conelet, but that at $Z_{3}$ was extremely steep sided, rising as a fingerlike spire 35 or 40 feet above the top of the basal mound.

At $20^{\mathrm{h}}$ a strong, somewhat explosive lava fountain was playing at vent $Z_{i}$ to heights of 100 to 150 feet, with some ejecta reaching 400 feet. Vent $Z_{3}$ was more explosive, sending showers of spatter and cinder to a height of about 400 feet. The northeast side of the spire at vent $Z_{3}$ had collapsed, revealing a clear view of the brightly glowing throat of the cone. Temperature readings with a Leeds and Northrup optical pyrometer gave an average temperature of $1,050^{\circ} \mathrm{C}$. Several lava flows were escaping around the cones. The most voluminous issued from the north side of the cone near the base of the spire at vent $Z_{3}$, poured down the slope of the cone, and turned eastward around the base to feed a big pond of lava that had accumulated east-northeast of the cone. Another stream of pahoehoe pouring down the northeast side of the cone was revealed by a break in the roof of the confining tube. Pyrometer readings on the brightly incandescent stream within the tube gave a temperature of $1,070^{\circ} \mathrm{C}$. Lava was spilling out of the pool at two points, just south of cone $T$ and east of cone $Z$, and active aa flow fronts were advancing over the top of the Kehena flow, but at $23^{\text {h }}$. they had not yet reached the line of the Pahoa-Kalapana road.

Mary 17. - At $1^{\mathrm{h}} 45^{\mathrm{m}}$.the most active flow front crossed the line of the Pahoa-Kalapana road on top of the Kehena flow but north of the main channel of that flow. On the other side of the pond, an overflow was sending a small lava stream around the northwest side of cone $Y$. The flow across the road slowed down greatly at about $3^{\text {h }}$. At $7^{\mathrm{h}}$ it was completely inactive, after advancing only about 300 feet beyond the road.

At $8^{\mathrm{h}}$ lava pouring from the cones was accumulating in a pond between cones $\mathrm{Z}$ and $\mathrm{T}$, but was not spilling over the lip of the pond at the break in slope (fig. 16). Vent $Z_{3}$ had become dominant, with a vigorous lava fountain reaching a height of 200 feet and occasional semiexplosive blasts reaching 400 feet. Most of the lava was issuing on the north side of the $Z_{3}$ cone. Vent $Z_{1}$ was producing weak sporadic 
blasts of cinder that reached heights of 75 to 100 feet above the lip of the cone, and a small lava flow on the northwest side of the cone.

At approximately $10^{\mathrm{h}}$ lava overflowed the lowest point on the rim of cone $\mathrm{T}$ and started to pour northeastward into the crater of the cone. About the same time lava also overflowed and moved southeastward from the pond between the hump at the break in slope and cone $\mathrm{T}$ (fig. 16). By $12^{\mathrm{h}} 30^{\mathrm{m}}$ the front of the flow was only 400 feet above the line of the Pahoa-Kalapana road, north of the flow of the previous night.

Where the lava poured down the steep slope just southeast of the edge of the pond, it produced a spectacular cascade (fig. 24), 25 to 50 feet in width, dividing into two parts part way down the slope and reuniting about 100 feet further down. The slope of the liquid surface, measured with a clinometer, was $22^{\circ}$. The upper, very liquid portion of the lava in this channel was flowing with a speed of 50 feet in 3 seconds. In this liquid many big blocks, as much as 25 feet long, 15 feet wide, and 15 feet high, were moved along at somewhat slower speed, rolling over and over on a more viscous and less rapidly moving understratum of the flow. From time to time portions of the more viscous lower portion were dragged up on the rolling blocks. Also, from time to time large blocks became wedged in the channel, causing

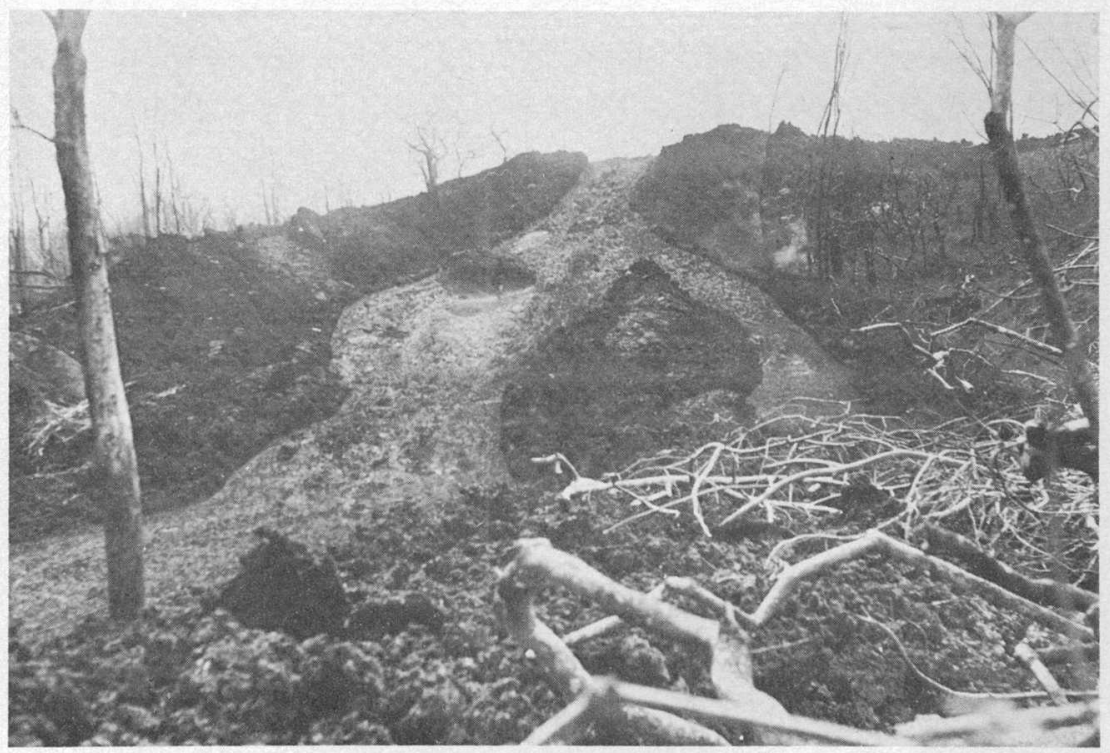

Figure 24.-Cascade of lava, about 25 feet wide at the top and 50 feet wide at the widest point, descending the steep slope above the Pahoa-Kalapana road at about noon on May 17. A large accretionary lava ball can be seen in the stream at the base of the cascade. 
temporary blockages and sometimes causing the more liquid portion to overflow the channel walls. The behavior of the rolling blocks indicated the uppermost liquid portion of the flow to be 4 to 6 feet deep. Calculations based on these observations indicate the rate of discharge of the most liquid material descending the channel to have been 60 to 80 cubic yards per second. Flow of the liquid material was obviously laminar in character. It was very quiet, accompanied only by a gentle swishing sound.

Beyond the foot of the steep slope, on a slope of $3^{\circ}$, the feeding channel of the flow was about 25 feet wide, about 12 to 15 feet deep, and the speed of flow was 40 feet in 7 seconds.

By $16^{\mathrm{n}}$ the front of the new flow was 300 feet southeast of the line of the former Pahoa-Kalapana road, on the top of the Kehena flow. The active front was aa, 10 to 12 feet high, about 700 feet wide, and advancing 2 to 3 feet per minute over a slope of $5^{\circ}$. At $20^{\mathrm{h}} 30^{\mathrm{m}}$ the front of the flow was about 1,000 feet southeast of the road. Several new overflows from the pond had taken place, and five separate streams of lava were pouring over the steep slope on the head of the Kehena flow. By $22^{\mathrm{b}}$ the earlier flow had nearly stopped, but a new tongue of aa was following a similar path and had already passed the line of the road.

May 18.-At $4^{\mathrm{n}} 30^{\mathrm{m}}$ the new flow front was 2,500 feet southeast of the. line of the road, but its advance was slowing down. The lava fountain at vent $Z_{3}$ was strong, playing to a height of about 200 feet, and a large volume of lava continued to pour into the pond north and east of the cone. At the northeast the pond was overflowing into the crater of cone $T$.

At $10^{\mathrm{b}} 15^{\mathrm{m}}$ the flow front was 3,000 feet beyond the line of the road but was stagnating. The front of a new flow tongue that had started during the night was about 500 feet beyond the road, but advancing only a few feet per hour. Vent $Z_{3}$ was fountaining 50 to 100 feet above the rim of the cone, with occasional scattered bursts reaching a height of 200 feet. Vent $Z_{1}$ was fuming heavily, with occasional semiexplosive bursts of cinder reaching a height of 250 feet. Three streams of lava were pouring from the pond over the steep slope to the southeast. During the morning repeated overflows at the heads of the streams sent broad sheets of red.incandescent lava over the adjacent surface of the steep slope.

At the foot of the steep slope the lava streams fed several small active flows of aa moving on the surface, but also in part disappeared beneath the surface to cause a swelling of the whole new fan of aa that had spread from the foot of the steep slope over the top of the Kehena 
flow. During the day several small flows of aa oozed out of fractures in the surface of the slightly older flows (fig. 25).

During the afternoon conditions at the vent remained similar to those during the morning. Two main rivers of lava, each 15 to 20 feet wide, rushed down the north and northeast slopes of the cone from a breach in the crater rim. The speed of flow in the northeast river was estimated to be about 20 miles per hour. Near the foot of the cone the north river plunged over a very steep slope, and there the speed of flow was estimated to be as much as 40 miles per hour. At the foot of the cone the rivers disappeared into tubes and fed the pond subterraneously. During the day the entire surface of the pond was slowly elevated, with very little molten lava actually flowing on it. Lava spilled from the pond not only southeastward, but also into an old crater south of the old cinder cone called Iilewa Crater and into the crater of cone T. At about $15^{\mathrm{h}}$ the lava had filled the crater of cone $\mathrm{T}$ to overflowing and had started to spill southeastward out of it. This stream joined the others pouring down the steep slope southwest of cone $\mathrm{T}$ to feed the several small active a flows moving over the head of the older Kehena flow.

Late in the evening several small tongues of lava started to spill eastward out of the crater of cone $\mathrm{T}$ over the head of the Keekee flow.

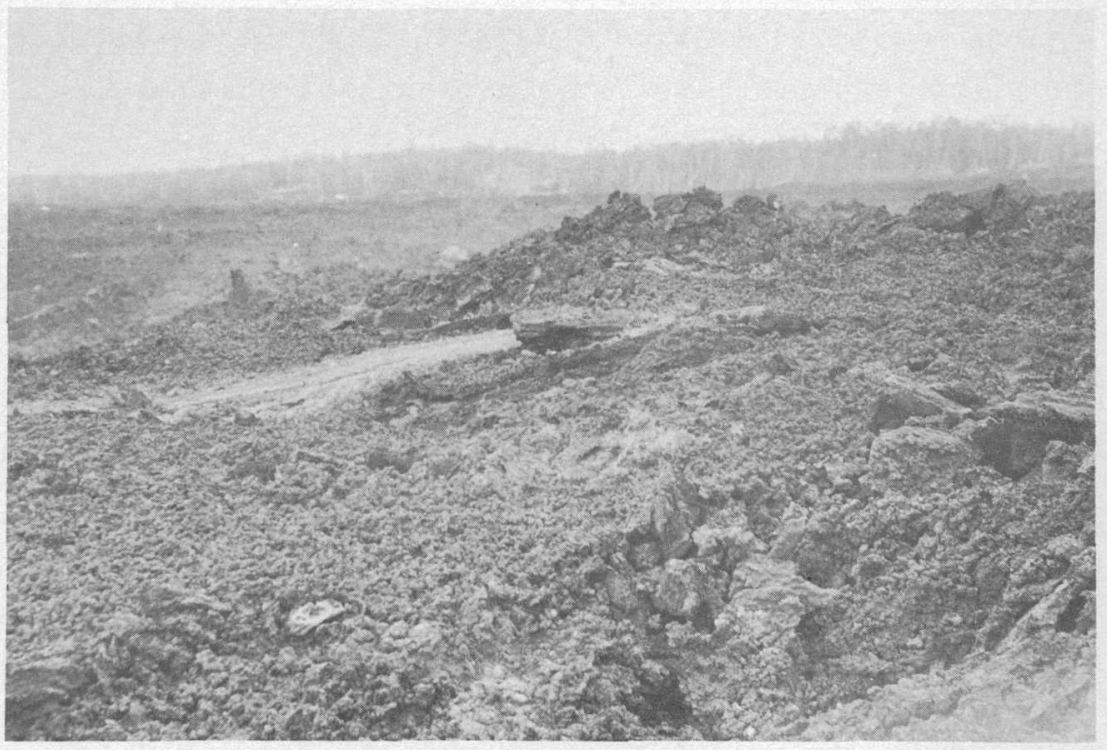

Figure 25.-Feeding river of a small aa flow issuing from a fissure in the top of a slightly older flow unit, near the foot of the steep slope above the line of the former PahoaKalapana road, at $14^{\text {h }}$ on May 18 . 
May 19.-At about $1^{\mathrm{h}} 30^{\mathrm{m}}$ an overflow from the pond between cones $\mathrm{Z}$ and $\mathrm{T}$ sent a stream of lava 300 feet long into the head of a valley around the northwest side of cone $T$. The flow continued for only about an hour.

During the morning conditions at vent $Z$ were about the same as on the previous day, except that the lava river on the north side of cone $Z_{3}$ had stopped flowing. A very active river on the northeast side of the cone continued to feed the pond northeast of the cone. Lava had stopped spilling into the crater of cone $\mathrm{T}$, but three rapid streams still flowed southeastward down the steep slope southwest of cone T. The most northerly of these streams was feeding an aa flow that was advancing over the top of the. Keekee flow. At $8^{\text {h }}$ the front of this flow was 1,000 feet beyond the Pahoa-Kalapana road and advancing at a rate of about 500 feet per hour. By $11^{\mathrm{h}} 30^{\mathrm{m}}$ the front of the flow was opposite the Iwasaki Camp but about 1,200 feet south of it.

At $11^{\mathrm{h}} 47^{\mathrm{m}}$ a sudden increase in lava effusion was observed at cone $Z_{3}$. The surge of lava traveled down the river channel that crossed the pond eastward to a point just south of cone $T$ and then plunged southeastward down the steep slope. The surge lasted only a few minutes. A similar surge occurred at $12^{\mathrm{h}} 50^{\mathrm{m}}$, and still another at $14^{\mathrm{h}}$. At $14^{\mathrm{h}} 10^{\mathrm{m}}$ the latter surge had reached the gentler slope at the foot of the steep incline and was causing an overflow of the feeding channel in that area. A flow of aa 12 to 24 inches thick moved out laterally from the channel, resembling in its motion a sheet of moderately warm tar, but with clinker sprouts forming on its surface. Most of the sprouts, up to 2 or 3 inches high, remained attached at their base to the surface of the flow, but others became detached and rolled loose on the moving surface of the sheet. Many of the latter fell free at the front of the flow and were overridden by the advancing lava. Clinker fragments still red hot in bright daylight rolled down the flow front and fractured into fragments as though they were completely solid, but many of the fragments were still sufficiently plastic to flatten and spread somewhat under their own weight within a few seconds after they came to rest.

At approximately $15^{\mathrm{h}}$ a new tongue broke out northeastward from the side of the active aa flow just southeast of the Pahoa-Kalapana road and started to advance rapidly in the direction of the Iwasaki Camp. The camp had been completely evacuated during March and partly reoccupied during the quiet period in April. As soon as the probable course of the new flow tongue became apparent, it was suggested that the camp again be evacuated. National Guard trucks were already standing by for that purpose, and evacuation 
started promptly. At $15^{\mathrm{h}} 45^{\mathrm{m}}$ the flow front was 2,000 feet from the camp, advancing over the top of the Keekee flow and through kipukas in the flow. At $17^{\mathrm{h}}$ the flow was slowing down greatly. At $17^{\mathrm{h}} 45^{\mathrm{m}}$ it was nearly stagnant, and it appeared that the camp might again escape destruction. This hope was short lived, however. At $18^{\mathrm{h}} 15^{\mathrm{m}}$ a new surge of lava poured over the crest of the steep slope just below the pond. At $18^{\mathrm{h}} 35^{\mathrm{m}}$ the surge had traveled completely down the flow, and was affecting the front. The toe of the flow and the whole top of the flow farther upstream swelled up visibly, rising as much as 4 feet, and the advance of the front again speeded up. At $18^{\mathrm{h}} 50^{\mathrm{m}}$ it was moving about 500 feet per hour. Still another big surge started down the flow at $18^{\mathrm{h}} 55^{\mathrm{m}}$.

At $20^{\mathrm{h}} 45^{\mathrm{m}}$ the flow had tumbled over the edge of the Keekee flow, and was nearly to the camp. The advancing front was 20 to 30 feet high and exceedingly active. Much incandescent material was exposed. Optical pyrometer readings on brightly glowing parts of the flow front gave temperatures of $1,045^{\circ}$ to $1,050^{\circ} \mathrm{C}$.

At $20^{\mathrm{h}} 50^{\mathrm{m}}$ the lava reached the edge of the camp, and the first building started to burn. Although the flow front continued to advance, the building had burned almost completely before it was finally pushed over by the lava. The destruction of other buildings followed, but nearly all the movable property had been removed. Most of the flow passed to the south, and the lava crowded laterally into the camp only enough to destroy its lower edge.

May 20.-At $7^{\mathrm{h}} 50^{\mathrm{m}}$ the front of the flow was about 2,000 feet southeast of the Iwasaki Camp but was nearly stagnant. Throughout the rest of the day activity at the vent area continued about the same as on the preceding day. Two new tongues of aa moved down over the top of the Keekee flow about half a mile south of the Iwasaki Camp. At $16^{\mathrm{h}} 30^{\mathrm{m}}$ the front of the second of these tongues had reached a distance of about 1.3 miles southeast of the former Pahoa-Kalapana road, but was advancing less than 100 feet an hour.

May 21.-During the night another overflow of the pond east of vent $Z$ occurred, sending a small tongue of lava into the valley northwest of cone $T$. Also, another tongue of aa started down over the top of the Kehena flow. By $5^{\mathrm{h}} 30^{\mathrm{m}}$ the front of the latter had reached about a mile beyond the Pahoa-Kalapana road. At $9^{\mathrm{h}}$ another tongue of aa started down through the forested kipuka between the Keekee and Kehena flows northwest of the Pahoa-Kalapana road. This tongue crossed the road at $13^{\mathrm{h}} 45^{\mathrm{m}}$ but advanced only about 300 feet beyond it. Early in the afternoon a new aa tongue started down the north side of the Keekee flow. At $15^{\mathrm{h}} 30^{\mathrm{m}}$ its front was half a mile above the remains of the Iwasaki Camp and headed directly toward 
it, but by $19^{\mathrm{h}}$ it had stagnated without reaching the camp. At $18^{\mathrm{h}}$ still another very active aa tongue was advancing down the center of the Kehena flow about 1,000 feet beyond the line of the road.

During the afternoon Curtis Kamai kept watch on the active vents. $\mathrm{He}$ reported that a surge of lava extrusion filled the river channels to, or nearly to, bank level approximately every 15 minutes, the level of lava in the channels dropping several feet between surges. The fountain at the vent was highest between surges and lowest during the surges.

May 22.-Conditions remained much the same as the day before. The principal point at which lava was spilling out of the pond was nearly east of cone $Z$, and the flow was progressing down the central part of the Kehena flow. At $12^{\mathrm{h}} 25^{\mathrm{m}}$ it had reached a point about three quarters of a mile beyond the former line of the Pahoa-Kalapana road. The feeding river of the flow was estimated to be moving about 20 miles per hour down the steep slope just southeast of the pond. Near the base of the steep slope the river swung around a $60^{\circ}$ turn, and the liquid surface of the river banked about $9^{\circ}$ in rounding the turn. Another smaller aa flow was advancing approximately along the boundary between the Keekee and Kehena flows above the line of the road.

During the afternoon lava again spilled from the pond into the crater of cone $\mathbf{T}$ and out of the crater on its east side. A flow from this area crossed the Pahoa-Kalapana road at $18^{\mathrm{h}}$. For several hours it appeared that this flow might reach the remains of the Iwasaki Camp, but by daylight the next morning it had become nearly stagnant, with its front half a mile from the camp.

About $23^{\mathrm{h}}$ a flow spilled out of the pond into the valley northwest of cone $\mathbf{T}$ and advanced around the north edge of the cone to a point just northwest of the Blowhole.

$M$ ay 23.- At $14^{\mathrm{h}}$ the lava fountain at vent $Z_{3}$ was playing to a height of about 150 feet above the cone (fig. 26). The latter was approximately 100 feet high and had buried most of cone $Z_{1}$. Lava was issuing from the cone through tubes and feeding the pond northeast of the cone. No river of lava was visible at or near the cone. The first visible molten lava was at the northeast edge of the pond, where two cascades were pouring into the crater of cone T. Almost all the southwest side of cone $\mathrm{T}$ had been buried by lava.

During the afternoon a small stream of pahoehoe was issuing at the northeast base of cone $\mathrm{T}$ and advancing northward around the west base of the Blowhole cone. The flow emerged at the end of a much cracked and slumped zone in the cinder on the side of the cone. 
This cracked zone had formed shortly after the end of lava activity in cone T, in late March, and had been fuming ever since then. A break in the tube roof near the vent revealed a stream of sluggish pahoehoe flowing about 0.5 foot per second within the tube. Small stalactites formed as the tube roof dripped slightly from refusion by heat radiated from the surface of the liquid stream beneath. No detectable gas was being given off through the hole in the tube. A pole thrust into the liquid in the bottom of the tube showed it to be about 1 foot deep. Its consistency resembled that of hot roofing tar, with a layer about 1 inch thick of more viscous material at the base.

Through the evening a small aa flow advanced over the top of the Keekee flow, passing several hundred feet south of the Iwasaki Camp about midnight. By midmorning of the next day it was virtually stagnant.

May 24.-For several days lava had been spilling out of the pond northeast of cone $Z$ into the crater of an old cinder cone just south of Iilewa Crater (fig. 16). During the night of May 23-24 the level of the lava in the crater reached the rim of the cone, and at $3^{\mathrm{h}} 45^{\mathrm{m}}$ Edward Wingate, Civil Defense warden, reported that it was spilling over the rim and flowing into the head of the valley northwest of cone $\mathrm{T}$. Thence it flowed down the valley north of cone $\mathrm{T}$ and formed a broad pool northeast and east of cone $\mathrm{T}$ and the Blowhole cone.

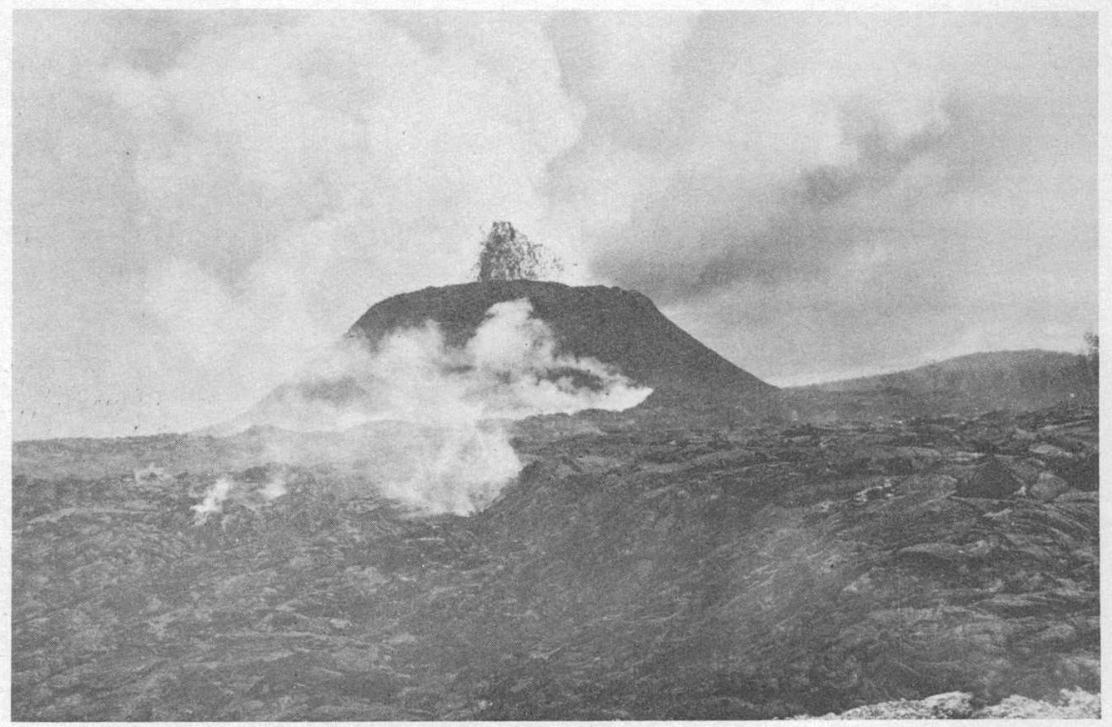

Figure 26. - Cinder and spatter cone, about 100 feet high, at vent $Z_{3}$ (fig. 16) at $14^{\text {h }}$ on May 23. The top of the fountain is visible above the rim of the cone. In the foreground is part of the broad lava pond that formed northeast of the cone. 
At about $6^{\mathrm{h}} 45^{\mathrm{m}}$ a small aa flow started from the edge of the pool just east of cone $\mathrm{T}$ and moved down the northeast edge of the Keekee flow. At $10^{\mathrm{h}} 40^{\mathrm{m}}$ this flow crossed the parking area recently constructed at the Pahoa-Kalapana road to accommodate sightseers. At $11^{\mathrm{h}} 25^{\mathrm{m}}$ the flow front was 1,000 feet beyond the road and still advancing at the rate of 500 feet per hour. At $16^{\mathrm{h}} 15^{\mathrm{m}}$ the flow front was about 20 feet high and advancing about 150 feet an hour over the top of a branch of the Keekee flow 2,000 feet beyond the road. By midnight the flow front had reached a diversion barrier above the Iwasaki Camp and was being split by it, part of the flow moving along each side of the barrier.

At $14^{\mathrm{h}}$ a voluminous flow of lava was escaping through a tube in the northeast base of cone $Z_{3}$, flowing northward in an open river across the pond filling the old crater south of Iilewa Crater, and spilling northeastward into the valley northwest of cone T. At the latter place it formed a spectacular cascade (fig. 27) and flowed at an estimated 35 miles per hour. At the northeast edge of the pond, east of the Blowhole cone, a flow was moving northeastward 2,000 feet northwest of the junction of the Pahoa-Kalapana and Kamaili roads, along the foot of an old southeast-facing fault scarp that extended from the edge of the pond toward vent area $R$. Along the base of the scarp it was filling open fissures, collapsed areas, and small grabens, some of them old, and some formed during the activity in March.

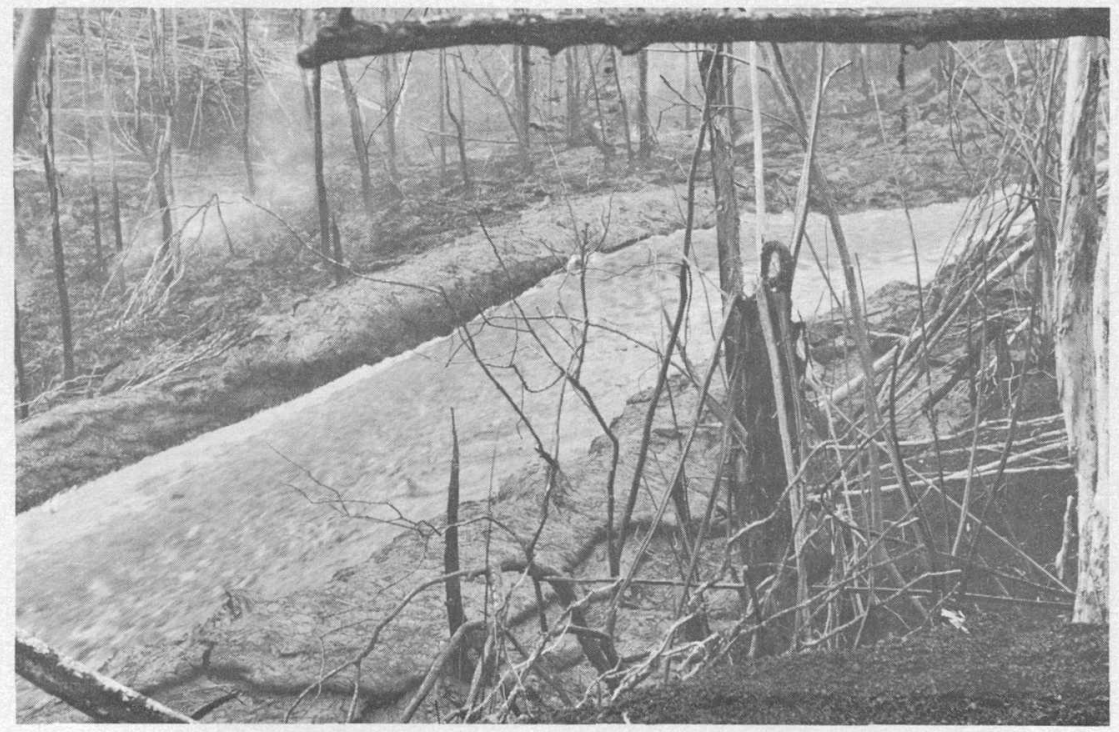

Figure 27.-Lava river, 12 feet wide, pouring into the head of the valley northwest of cone $T$ at $14^{\mathrm{h}}$ on May 24. The speed of this river, which was flowing down a $30^{\circ}$ slope, was estimated to be at least 35 miles per hour. 
About $17^{\text {h }}$ the speed of the flow moving eastward along the old fault scarp increased greatly, and the lava commenced to crowd southeastward toward the top of a recently planted coffee field. Shortly afterward a thin, very fluid flow of aa diverged from the flow along the fault scarp and moved rapidly down through the coffee field toward the junction of the Pahoa-Kalapana and Kamaili roads. At $21^{\mathrm{h}} 45^{\mathrm{m}}$ the flow moved across the road junction and continued down over the upper portion of the Kamaili road, coming to a stop at about $22^{\mathrm{h}} 30^{\mathrm{m}}$, 600 feet beyond the junction.

May 25.-Just after midnight another rapid spillover from the flow along the fault scarp followed approximately the course of the earlier one. By $1^{\mathrm{h}}$ it was approximately 800 feet below the Pahoa-Kalapana road. At $10^{\text {h }}$ the flow front was 1,200 feet beyond the road but moving very slowly.

During the previous day sightseers had been permitted to go to the edge of the spectacular cascade northwest of cone T. During the morning of May 25, however, lava started to spill over the cone rim behind the observation area, and because of danger that they might be cut off by another flow, visitors were advised to keep out of the area along the cascade. The cascade itself remained breath-taking, even to experienced observers. It was 10 to 15 feet in width and about 300 feet long, and the amazingly fluid-appearing lava swept down the slope of $35^{\circ}$ at speeds certainly in excess of 30 miles per hour. Near the head of the cascade the stream formed a stationary wave about 4 feet high. From time to time the level of the liquid rose above the rim of the channel and thin sheets of lava spread out on each side of it, building low smooth levees that helped to confine the stream. As the liquid level receded again, lava stalactites several inches long were exposed hanging on the banks of the stream. Many of these stalactites were still flexible and swayed back and forth in gusts of wind, or as their tips encountered the moving liquid beneath them they swayed like so many willow roots along the bank of a stream.

About noon a new overflow of the pond east of cone $T$ sent another flow of aa in the direction of the former junction of the Pahoa-Kalapana and Kamaili roads. At about the same time the earlier flow increased in speed again. Its front was 1,500 feet beyond the road junction and approximately 3,400 feet from the remains of the Iwasaki Camp, which was again placed in jeopardy. All easily movable property had been removed from the camp earlier, but now one house was moved away intact, and workmen commenced tearing down others and removing the materials to a safe location.

At $16^{\mathrm{h}} 30^{\mathrm{m}}$ the new flow crossed the area of the former road junction, and shortly afterward it joined the older flow, which was still advancing toward the Iwasaki Camp. 
During the evening conditions at the vent remained about the same as they had been for the past several days. At $Z_{3}$ a lava fountain was playing to heights of 50 to 100 feet above the rim of the cone, and a voluminous flow of lava was pouring into the pond east of the cone, which in turn was still draining into the valley northwest of cone $\mathbf{T}$ and thence into the pond east of cone $T$. Overflow from the latter pond continued to feed the flows toward the Iwasaki Camp. The cone at vent $Z_{1}$ had been almost completely buried by the $Z_{3}$ cone, but the vent continued to exist as a crater on the southwest side of the cone, throwing occasional showers of cinders to heights as great as 200 feet.

May 26.-At approximately $1^{\mathrm{h}}$ the front of the lava flow reached the remainder of the Iwasaki Camp and soon covered it completely: For the next several hours it continued moving into the canefields beyond the site of the camp. At $9^{n} 45^{\mathrm{m}}$ two more tongues of lava were moving down over the former road junction to augment the flow still advancing beyond the Iwasaki Camp.

During the morning activity at the vent area was approximately the same as it had been the evening before, with the fountain at vent $Z_{3}$ reaching heights as great as 150 feet, and the lava still abundantly pouring into the pond east of the cone. At $11^{h}$ the vent activity was under observation by Richard Burns, ranger of Hawaii National Park, and Claude Jendrusch of Honolulu. At about $11^{\mathrm{h}} 15^{\mathrm{m}}$, lava fountain activity ceased abruptly as they watched, and no further draining of lava into the pond was observed. Volcanic tremor ceased on the Pahoa seismograph at $11^{\mathrm{h}} 13^{\mathrm{m}}$. For several hours lava continued draining from the ponds into the heads of the flows, but the eruption was over.

\section{EVENTS FOLLOWING TAE ERUPTION}

On May 27 we crossed the pond of solidified lava and climbed the cone at vent $Z$. There were no signs of movement in the pond, although red glow was still visible in many cracks from a few inches to a few feet below the surface. Drainage of fluid lava from beneath the crust had resulted in irregular collapse of the surface of the pond, some areas having sunk as much as 15 feet. At the far east edge of the pond, where one of the lava streams had been escaping to flow over the older flows to the southeast, a lava tube 10 feet in diameter plunged steeply downward. About 75 feet from its upper opening, the walls of the tube were brightly incandescent. There was no sign of incandescence in the craters of the cone, which were floored with heaps of debris from collapse of the crater walls. Only light blue fume was escaping in the $Z_{3}$ crater, and none at all in the $Z_{1}$ crater.

During the next few weeks moderately heavy fume liberation continued at cone $Z$ and the Blowhole cone in vent area $T$, but only light 
fuming came from the main crater at cone $T$. A spot near the center of the former lava pond between cones $T$ and $Z$ also :liberated modorately heavy fume.

Steam and light traces of sulfurous fume continued to escape at many other vents of the eruption. Steam became particularly heavy within a few hours of the end of heavy rains and very light or unnoticeable during very dry weather. Steaming was particularly pronounced at the cracks extending through the center of Kapoho village, at vent areas $\mathrm{E}, \mathrm{M}, \mathrm{A}$, and $\mathrm{R}$; and at cracks a third of a mile northeast of cone T. Along cracks just southwest of vent $M$, and in the vicinity of the old road at vent area $R$, moderately abundant sulfur deposition occurred. Southwest of vent $M$, steam bubbling up through water in the cracks at times made a loud gurgling noise, which at first was alarming to people working in the vicinity. Steaming and sulfur deposition still continued; with only slightly diminished intensity, a year after the end of the eruption.

Starting on June 16, Civil Defense wardens on duty at night observed pale-blue flames issuing from cracks in the ground near the road, between the road and the collapse crater in vent area $R$, and a $\bar{t}$ times over the crater itself. Most of the flames were only a few inches high, but some.were as much as 2 feet: Sometimes as many as 20 or 30 flames were visible at one time. Stamping or striking the ground with a pole caused the flames over an area.50 feet in diameter to puff visibly and often caused new flames to appear for a short time. Most of the flaming cracks were in ground not covered by lava flows during the eruption. A slight odor of sulfur gas commonly was detectable, but even more pronounced was a peculiar odor resembling that of boiling cabbage, believed to be caused by organic matter decomposing under the influence of the abundant slightly acid steam that still was issuing at many places in the area. Temperatures up to $260^{\circ} \mathrm{C}$ were measured with mercury thermometers in hot cracks in the area of flames. The flames continued to be visible every night until about the end of July. They were too pale to be seen ordinarily in daylight. The flames may have been the result of burning sulfur in the cracks in this solfataric area, but the odor of sulfur dioxide was not particularly strong in the immediate vicinity of the flames and many of the flames were not at places where sulfur had been deposited at the surface. More probably they resulted from the burning of hydrocarbon gas derived from decomposing vegetable matter in the soil and were similar to the pale-blue flames seen near the edge of some active lava flows.

Several places on the thick accumulation of lava flows southeast of cone $\mathrm{Z}$ remained very hot for months after the end of the eruption. 
In mid-November the aa clinker at the surface of the flow near the new Pahoa-Kalapana road (pl. 1), approximately over the center of the Keekee flow, was so hot that it would ignite a dry stick within 15 seconds. A thermocouple reading at that spot on November 23 gave a temperature of $465^{\circ} \mathrm{C}$. The total accumulation of lava in that area probably was between 50 and 75 feet thick. Even there, however, most of the upper part of the lava cooled quickly. A month after the end of the eruption bulldozers had completed a temporary road across the flows.

\section{THE CONES}

Most of the cones built at the vents of the 1955 eruption are spatter cones and cinder-and-spatter cones of kinds typical of the activity of Kilauea and Mauna Loa (Wentworth and Macdonald, 1953, p. 22). Spatter ramparts 1 to 10 feet high were built along portions of the vent fissures where activity lasted only a few hours. Cones were built at places where activity continued for many hours or days. Small and gas-poor fountains produced well-agglutinated spatter cones, such as those in the old Pahoa-Kalapana road and Hayashi's yard (vent area $R$ ). The principal vents of the eruption ( $E, J, M, S_{1}, T, Y$, and Z) were characterized by big gas-rich lava fountains. They built more complex but less well-agglutinated cones of spatter, cinder, and pumice. Thin lava flows are intercalated with the fragmental ejecta in the cones. These flows originated partly by overflow of lava over the crater rim, but more commonly they were rootless flows formed by the coalescence of large amounts of liquid spatter that fell in showers on the outer slope of the cone. Most of the cones are breached on the side from which the major stream of lava escaped, because the ejecta falling on that side were carried away by the lava and could not accumulate to build the cone wall.

Pumice and Pele's hair (threads of natural spun glass) were formed by the major lava fountains. Most of it fell on and close to the cones, but some of this very light material drifted for long distances in the wind. On March 21 and 22 pumice fell abundantly in Pahoa, 5 miles from the active vent at $\mathrm{T}$, and on those and other days small amounts of Pele's hair and very small bits of pumice fell in Hilo and along the coast farther north, as much as 25 miles from the vents. Heavy falls of pumice close to cone $\mathrm{T}$ completely stripped ohia (Metrosideris) and guiava trees of leaves, small branches, and most of the bark, leaving the trunks almost bare and with a shredded appearance as though they had been exposed to a violent sandblast. The pumice fell almost vertically; there was no evidence of any horizontal blasts. Fronds of tree ferns were so heavily weighted by pumice that they were broken off. The ferns appeared dead. The 
great recuperative powers of plants in a climate such as that of Puna were demonstrated by. the fact that within 3 months of the end of activity. at vent $T$ the ferns were sending out new fronds and the trees.were covered with new green leaves.

At slightly greater distances from the vent the lighter fall of pumice, although it did minor and temporary damage to the plants, appeared to have an overall beneficial effect. Both sugarcane and bananas were reported to look as though they had been fertilized, although no fertilizer was applied.

When activity resumed at vent $Z$, after the period of quiescence in mid-April, it was somewhat different in character than that earlier in the eruption and that after May 16. Instead of true lava fountains, which are continuous jets of liquid lava shooting into the air, the fountains consisted of showers of discrete ejecta resembling those characteristic of Strombolian activity at such continental volcanoes as Stromboli and Parícutin, although lacking the fusiform bombs typical of Strombolian activity (Wentworth and Macdonald, 1953, p. 81). The resulting cone consisted largely of loose cinder, instead of welded spatter and cinder. It was wholly buried by cinder and spatter during the revival of more typical Hawaiian activity after May 16.

\section{THE FLOWS}

Pahoehoo is present among the lava flows of the 1955 eruption, but it is much less abundant than aa. In all of the major flows aa greatly predominates.

Close to the vents; the flows extruded on February 28 and March 1 were viscous pahoehoe very close to the point of changing over to aa. By the time the lava had reached a distance of a few hundred feet from the vents the conversion to aa was nearly complete.

The pahoehoe flows on March 2, close to vents $\mathrm{E}$ to $\mathrm{M}$, were much more fluid than those of February 28, but still were close to the point of transition into aa. The flows were rich in gas, and some toes were merely gas-filled hollow shells.

The flows extruded east of vent T on April 27 and 28, following the period of quiescence in mid-April, were of slow-moving, heavy pahoehoe lava that had lost much of its original gas content before eruption. These flows resembled those formed by overflow of the Halemaumau lava lake onto the floor of Kilauea caldera in years prior to 1924 and those extruded after the period of inactivity during the 1949 eruption of Mauna Loa (Macdonald and Orr, 1950, p. 14, 23-24). They probably represent lava that during the period of quiescence had stood in liquid condition at levels high in the feeding conduit, where gas was actively coming out of solution in the liquid and escaping to the sur- 
face as fume. These flows of dense pahoehoe were almost entirely buried by later flows of aa.

The aa flows of the eruption are typical in every respect and require no special description. Although some of the lavas are more siliceous than typical Hawaiian basalts, none of the flows can be classified as block lava in the restricted sense (Macdonald, 1953, p. 182).

VOLUME AND RATE OF EXTRUSION OF THE LAVA

The area covered by the cones and flows, and the volume of each, are given in table 1. Areas were scaled from the map. The flows and cones together cover a total area of 3,900 acres, or approximately 6.1 square miles.

TABLE 1.-Area and volume of 1955 flows and cones

\begin{tabular}{|c|c|c|c|c|c|}
\hline \multirow[b]{2}{*}{ Date } & \multirow{2}{*}{$\begin{array}{c}\text { Vents } \\
\text { (shown on } \\
\text { pl. 1) }\end{array}$} & \multicolumn{2}{|c|}{ Cones } & \multicolumn{2}{|c|}{ Flows } \\
\hline & & $\begin{array}{l}\text { Area } \\
\text { (square } \\
\text { yards) }\end{array}$ & $\begin{array}{c}\text { Volume (cuble } \\
\text { yards) }\end{array}$ & $\begin{array}{l}\text { Area (square } \\
\text { yards) }\end{array}$ & $\begin{array}{c}\text { Volume (cubic } \\
\text { yards) }\end{array}$ \\
\hline $\begin{array}{l}\text { Feb. 28-Mar. 1. } \\
\text { Mar. 2-6. } \\
\text { Mar. 12-Apr. 6 } \\
\text { Apr. 30-May 26. }\end{array}$ & $\begin{array}{l}\mathrm{A}-\mathrm{D} \\
\mathrm{E}-\mathrm{P} \\
\mathrm{Q}-\mathrm{Y} \\
\mathbf{Z}\end{array}$ & $\begin{array}{r}19,000 \\
122,000 \\
178,000 \\
12,000\end{array}$ & $\begin{array}{r}100,000 \\
1,200,000 \\
1,100,000 \\
400,000\end{array}$ & $\begin{array}{r}440,000 \\
5,350,000 \\
10,810,000 \\
11,960,000\end{array}$ & $\begin{array}{r}1,070,000 \\
34,770,000 \\
69,590,000 \\
33,070,000\end{array}$ \\
\hline \multicolumn{2}{|c|}{$\begin{array}{l}\text { Total for whole erup- } \\
\text { tion }\end{array}$} & 321,000 & $2,800,000$ & $18,560,000$ & $138,500,000$ \\
\hline
\end{tabular}

1 New area only. The $Z$ cones covered a total area of 40,000 square yards, and the flows from them covered a total area of $4,720,000$ square yards, but most of the area covered was already occupled by earlier flows of the 1955 eruption.

The thickness of the flows ranges from less than 1 foot to 70 feet. The average thickness of the Kii, Keekee, and Kehena flows is between 20 and 25 feet, a figure of 21 feet being assumed in calculating the volumes. The average thickness of the Kaueleau flow is approximately 15 feet. The greatest thicknesses of lava are approximately 50 feet where the flows from vent $Z$ accumulated on top of the Keekee and Kehena flows, and 70 feet where the latter two flows built lava deltas seaward of the old sea cliff. Estimates of thickness have been checked locally by peg leveling at the edges of the flows and by lines of differential levels run before and after the eruption by the Territorial Highway Department along the line of the Pahoa-Kapoho road.

Volumes given in table 1 are conservative approximations that were calculated from the approximate shapes of the cones and from estimates of the thicknesses of the flows. Reestimates of the thicknesses of the flows, based on the results of leveling, result in a total volume 
of lava a little greater than that based on earlier estimates (Macdonald and Eaton, 1955a, p. 7-8). The total volume of extrusives, including both flows and cones, is approximately 141 million cubic yards, or roughly one thirty-eighth of a cubic mile. It is a little more than twice the volume of the lava poured into Halemaumau crater during the eruption of 1952, about half the volume of the nearby flows of the 1840 eruption of Kilauea, and a little more than one-fifth that of the flows of such big eruptions of Mauna Loa as those of 1859 and 1950.

It is difficult to obtain a close approximation of the amount of open space represented by vesicularity of the flows, open tubes in pahoehoe, spaces between fragments in aa clinker, and similar spaces in the cones. If the very rough average figure of 20 percent is taken as the proportion of open space, the volume of lava in dense state would be approximately 112 million cubic yards.

Figure 28 shows the estimated rate of extrusion of lava throughout the eruption, based on the calculated volumes of successive flows. The similarity in pattern to the graph of intensity of volcanic tremor on the Pahoa seismograph (fig. 42) is striking and confirms the validity of the use of the amplitude of tremor as an indicator of the relative rates of lava extrusion. The most rapid outpouring of lava occurred during the period of the very high lava fountain at vent $\mathrm{E}$, on March 4, when a rate of more than 500,000 cubic yards per hour probably was attained. In comparison, the greatest rate of extrusion at other vents later in the eruption probably did not equal half that.

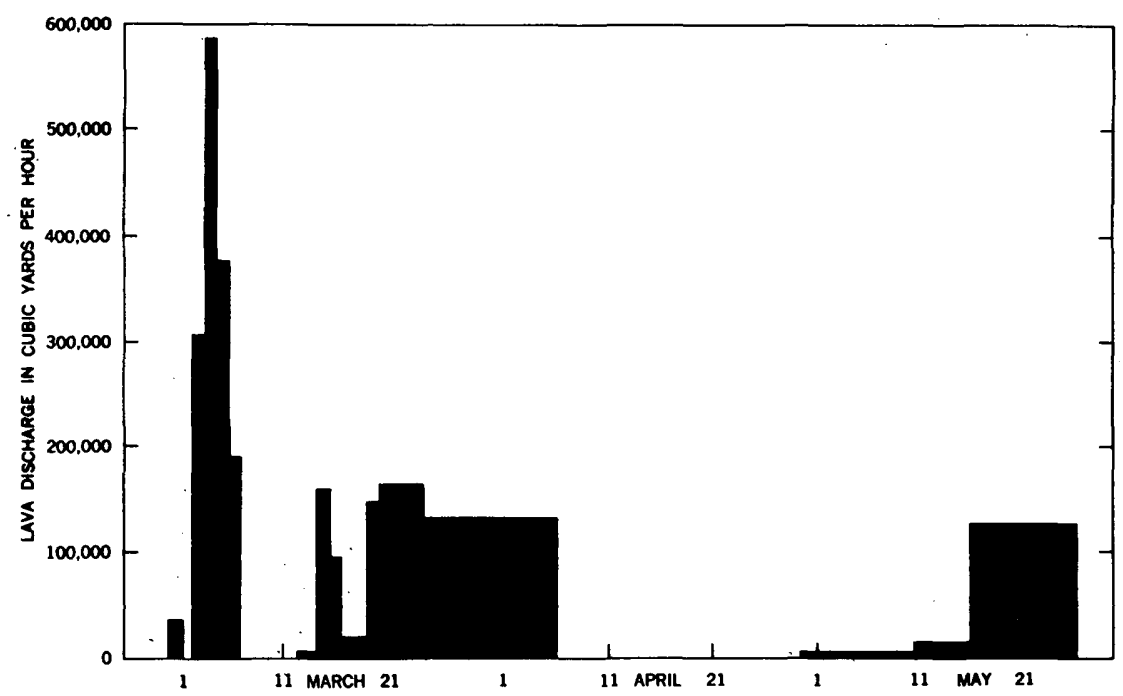

FIGORE 28.-Graph showing the approximate rate of lava discharge during the 1955 eruption of Kllauea. 
The rate of extrusion on March 4, averaged over several hours, was approximately 160 cubic yards per second. This may be compared with an estimated maximum rate of 760 cubic yards per second, and a more normal rate of 105 cubic yards per second, during the 1940 eruption of Mauna Loa (Macdonald, 1954a, p. 137-138); and a maximum rate of about 520 cubic yards per second during the 1952 eruption of Kilauea (Macdonald, 1955a, p. 83-84). The maximum rate of extrusion on March 4 undoubtedly was somewhat greater than the average figure given above, but probably did not exceed half that of the 1952 eruption.

\section{COMPOSITION OF THE LAVAS}

Studies of hand specimens and thin sections indicate that the lavas of the 1955 eruption range from olivine-bearing tholeiitic basalt to andesitic basalt. Olivine phenocrysts, up to 2 or $3 \mathrm{~mm}$ and rarely as much as $5 \mathrm{~mm}$ across, are common in all the flows, though somewhat more abundant in the later ones than in the flow of February 28 (p. 9 ). Small phenocrysts of plagioclase feldspar also are present in all the flows and range in composition from about sodic bytownite to sodic labradorite. Microphenocrysts of hypersthene are conspicuous in sections of the February 28 flow, and a few have been noted by both Macdonald and C. E. Tilley (written communication, 1959) in some of the later lavas. A specimen of the last flow to cross the PahoaKalapana road, in late May, contains a single black platy phenocryst of augite about $5 \mathrm{~mm}$ long and $0.5 \mathrm{~mm}$ thick. Fragments of the augite immersed in oil are pale brown and very slightly pleochroic, with inclined extinction, $(+) 2 \mathrm{~V}=60^{\circ} \pm$, and no apparent dispersion. The groundmass of the lavas ranges from intersertal to intergranular and consists of labradorite, pyroxene, mangetite, ilmenite, and glass. Grains of olivine of the same size as the groundmass minerals are common, but many of them appear to have been somewhat rounded by resorption, and they probably should be regarded as belonging to the same intratelluric generation as the phenocrysts rather than to the groundmass generation. Some of the groundmass pyroxene has a $2 \mathrm{~V}$ of $50^{\circ}$ or more, but many grains are pigeonite with $2 \mathrm{~V}$ less than $30^{\circ}$.

Inclusions of microgabbro are numerous in lavas erupted during the first and second phases of the eruption from vents near Puu Honuaula and Puu Kii. The inclusions range from angular to moderately well rounded and range in size from less than half an inch to diameter to more than 2 inches. Some of them appear to have been disintegrating in the lava at the time the latter froze to immobility. They consist largely of labradorite and pyroxene (subcalcic augite to pigeonite) 
with a little magnetite and olivine. The individual grains in the rock average about a millimeter in length. Some of the inclusions are quite dense, but others have an open texture that resembles diktytaxitic structure in some basaltic.lavas and the coarser open-textured gabbros earlier described from West Maui volcano and elsewhere in the Hawaiian Islands (Stearns and Macdonald, 1942, p. 328, pl. 43-C; Macdonald, 1949a, p. 1552).

Chemical analyses and norms of lavas extruded at various stages of the 1955 eruption are given in table 2 , columns 1 to 10 , together with analysis of the lava of 1954 in Kilauea caldera (column 11). Although the lavas contain phenocrysts of olivine, sometimes in moderate abundance, all of them are more than saturated with silica, as is demonstrated by the presence of quartz in the norm. The existence of olivine is the result of incomplete reaction of that mineral, a very early member of the reaction series, with the residual liquid. Conspicuous rounding and embayment of many of the phenocrysts indicate that reaction was in progress but was interrupted by the rapid cooling attendant on extrusion.

The 1955 lavas are richer in silica, alumina, and alkalies and reciprocally are poorer in lime and magnesia than the average of pre-1954 historic olivine basalts and basalts of Kilauea (column 12, table 2). Indeed, the flow of February 28 and March 1 (column 1) contains 51.24 percent silica, more than any other lava erupted by Kilauea in historic time. Two prehistoric lavas are even richer in silica, however, and the silica content of several historic and prehistoric lavas falls within the general range of the lavas of 1955 .

The presence of excess silica in the lavas is not unusual. As pointed out by Powers (1955), most of the rocks of Kilauea are saturated or slightly oversaturated with silica.

The flow of February 28 and March 1 and the Kii flow of March 2 to 6 may be classified as basaltic andesite on the basis of the composition of the normative feldspar $\left(A b_{51.8}\right.$ and $\left.A b_{51.4}\right)$, although in thin section the identifiable feldspar is labradorite, and on the basis of color index the rocks would be classed as basalt. The Niggli values for $q z$ are slightly negative; hence, the rocks do not fall within the group of basaltic andesites as defined by Williams (1950, p. 235), but since they contain normative quartz neither do they fall into Williams' group of basalts. According to the classification proposed by Rittmann (1952) the rocks are andesine basalt. On the basis of actual mineral composition (mode) they are basalts but with strongly andesitic affinities as indicated by the presence of quartz and andesine in the norm, and therefore, they are herein termed andesitic basalt. 
TABLE 2.-Chemical composition of the 1954 and 1955 lavas of Kilauea

[In weight percent. Analysts: Lois Trumbull (sample 1), Marjorie Balazs (samples 2-4, 6, 8-11), both of the U.S. Geol. Survey; Takashi Katsura (samples 5 and 7), of the Univ. of Hawali]

\begin{tabular}{|c|c|c|c|c|c|c|c|c|c|c|c|c|}
\hline & 1 & 2 & 3 & 4 & 5 & 6 & 7 & 8 & $\theta$ & 10 & 11 & 12 \\
\hline 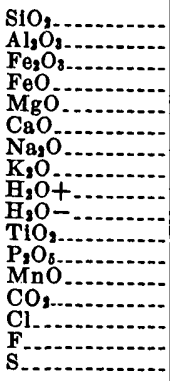 & $\begin{array}{r}51.24 \\
13.60 \\
1.87 \\
11.19 \\
5.12 \\
9.03 \\
2.81 \\
.83 \\
.03 \\
.00 \\
3.74 \\
.41 \\
.18 \\
.01 \\
.01 \\
.06 \\
.01\end{array}$ & $\begin{array}{r}50.99 \\
13.73 \\
3.39 \\
9.36 \\
5.42 \\
9.38 \\
2.75 \\
.80 \\
.03 \\
.01 \\
3.57 \\
.39 \\
.18 \\
.01 \\
.01 \\
.05 \\
.00\end{array}$ & $\begin{array}{r}50.91 \\
13.72 \\
2.65 \\
9.87 \\
5.64 \\
9.58 \\
2.68 \\
.74 \\
.01 \\
.02 \\
3.60 \\
.40 \\
.18 \\
.00 \\
.02 \\
.05 \\
.00\end{array}$ & $\begin{array}{r}50.94 \\
13.79 \\
2.16 \\
10.25 \\
5.57 \\
9.57 \\
2.70 \\
.76 \\
.03 \\
.02 \\
3.70 \\
.40 \\
.18 \\
.00 \\
.03 \\
.05 \\
.00\end{array}$ & $\begin{array}{r}51.06 \\
13.72 \\
2.44 \\
10.34 \\
5.44 \\
9.46 \\
2.62 \\
.76 \\
.12 \\
.00 \\
3.65 \\
.39 \\
.18 \\
\hdashline \\
\hdashline \\
\hdashline\end{array}$ & $\begin{array}{r}50.55 \\
13.84 \\
2.98 \\
9.32 \\
6.19 \\
10.10 \\
2.61 \\
.67 \\
.02 \\
.01 \\
3.31 \\
.30 \\
.18 \\
.01 \\
.01 \\
.05 \\
.00\end{array}$ & $\begin{array}{r}50.37 \\
14.02 \\
1.88 \\
10.07 \\
6.75 \\
10.39 \\
2.35 \\
.62 \\
.16 \\
.04 \\
3.09 \\
.32 \\
.17 \\
\\
\hdashline \\
\hdashline \\
\hdashline\end{array}$ & $\begin{array}{r}50.61 \\
13.80 \\
2.66 \\
9.31 \\
6.61 \\
10.28 \\
2.49 \\
.69 \\
.00 \\
.01 \\
3.12 \\
.34 \\
.17 \\
.01 \\
.01 \\
.04 \\
.00\end{array}$ & $\begin{array}{r}50.58 \\
13.74 \\
1.97 \\
9.95 \\
6.57 \\
10.27 \\
2.51 \\
.72 \\
.06 \\
.01 \\
3.22 \\
.35 \\
.17 \\
.00 \\
.04 \\
.04 \\
.00\end{array}$ & $\begin{array}{r}50.53 \\
13.95 \\
2.56 \\
9.40 \\
6.33 \\
10.28 \\
2.56 \\
.64 \\
.00 \\
.01 \\
3.23 \\
.28 \\
.17 \\
.00 \\
.01 \\
.04 \\
.00\end{array}$ & $\begin{array}{r}50.20 \\
13.73 \\
2.65 \\
8.80 \\
7.20 \\
11.56 \\
2.25 \\
.57 \\
.00 \\
.00 \\
2.72 \\
.28 \\
.17 \\
.01 \\
.02 \\
.05 \\
\ldots . .-\end{array}$ & 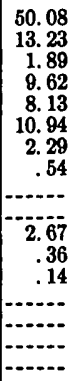 \\
\hline Total & 100.14 & 100.07 & 100.07 & 100.15 & 100.18 & 100.15 & 100.23 & 100.15 & 100.20 & 99.99 & 100.21 & \\
\hline
\end{tabular}

Minor elements

[In parts per million. Analyst: P. R. Barnett, U.S. Geol. Survey] ${ }^{2}$

\begin{tabular}{|c|c|c|c|c|c|c|c|c|c|c|c|c|}
\hline 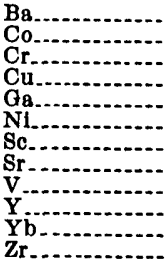 & $\begin{array}{r}250 \\
48 \\
100 \\
200 \\
18 \\
100 \\
40 \\
690 \\
400 \\
70 \\
7.5 \\
290\end{array}$ & $\begin{array}{r}250 \\
45 \\
140 \\
200 \\
17 \\
110 \\
40 \\
740 \\
400 \\
68 \\
7.0 \\
270\end{array}$ & $\begin{array}{r}240 \\
50 \\
140 \\
200 \\
17 \\
120 \\
40 \\
720 \\
390 \\
69 \\
7.1 \\
260\end{array}$ & $\begin{array}{r}230 \\
48 \\
140 \\
210 \\
17 \\
120 \\
40 \\
670 \\
400 \\
69 \\
6.7 \\
260\end{array}$ & 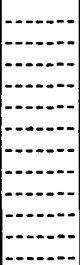 & $\begin{array}{r}220 \\
46 \\
170 \\
210 \\
16 \\
130 \\
40 \\
700 \\
370 \\
63 \\
6.1 \\
230\end{array}$ & 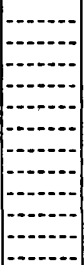 & $\begin{array}{c}220 \\
46 \\
210 \\
190 \\
16 \\
150 \\
40 \\
750 \\
340 \\
66 \\
6.0 \\
230\end{array}$ & $\begin{array}{r}220 \\
45 \\
210 \\
200 \\
15 \\
150 \\
40 \\
760 \\
340 \\
65 \\
5.8 \\
220\end{array}$ & $\begin{array}{r}230 \\
45 \\
210 \\
210 \\
16 \\
140 \\
40 \\
760 \\
350 \\
63 \\
6.2 \\
220\end{array}$ & $\begin{array}{r}300 \\
48 \\
310 \\
180 \\
14 \\
150 \\
40 \\
770 \\
370 \\
55 \\
5.0 \\
170\end{array}$ & \\
\hline
\end{tabular}

Norms

\begin{tabular}{|c|c|c|c|c|c|c|c|c|c|c|c|c|}
\hline $\begin{array}{l}\text { Q } \\
\text { ab } \\
\text { an } \\
\text { di }\left\{\begin{array}{l}\text { wo } \\
\text { en } \\
\text { fs }\end{array}\right. \\
\text { by }\left\{\begin{array}{l}\text { en } \\
\text { fs }\end{array}\right. \\
\text { il }\end{array}$ & $\begin{array}{r}4.68 \\
5.00 \\
23.58 \\
21.96 \\
7.66 \\
3.70 \\
3.83 \\
9.10 \\
9.37 \\
2.78 \\
7.14 \\
1.68\end{array}$ & $\begin{array}{r}5.10 \\
5.00 \\
23.58 \\
22.24 \\
9.05 \\
5.20 \\
3.43 \\
8.40 \\
5.41 \\
4.87 \\
6.84 \\
1.01\end{array}$ & $\begin{array}{r}4.38 \\
4.45 \\
23.06 \\
22.80 \\
9.16 \\
5.10 \\
3.70 \\
9.00 \\
6.73 \\
3.71 \\
6.84 \\
1.01\end{array}$ & $\begin{array}{r}4.14 \\
4.45 \\
23.06 \\
23.07 \\
9.05 \\
4.80 \\
3.96 \\
9.10 \\
7.26 \\
3.25 \\
6.99 \\
1.01\end{array}$ & $\begin{array}{r}5.16 \\
4.45 \\
22.01 \\
23.35 \\
8.70 \\
4.60 \\
3.83 \\
9.00 \\
7.52 \\
3.48 \\
6.84 \\
1.01\end{array}$ & $\begin{array}{r}3.72 \\
3.89 \\
22.01 \\
23.91 \\
10.09 \\
5.90 \\
3.70 \\
9.60 \\
5.81 \\
4.41 \\
6.23 \\
.67\end{array}$ & $\begin{array}{r}2.64 \\
3.34 \\
19.91 \\
25.85 \\
9.78 \\
5.60 \\
3.96 \\
11.30 \\
8.05 \\
2.78 \\
5.93 \\
.67\end{array}$ & $\begin{array}{r}2.76 \\
3.89 \\
20.96 \\
24.46 \\
10.32 \\
6.10 \\
3.70 \\
10.40 \\
7.52 \\
3.94 \\
5.93 \\
.67\end{array}$ & $\begin{array}{r}2.94 \\
3.89 \\
20.96 \\
24.19 \\
9.78 \\
5.60 \\
3.96 \\
10.80 \\
7.66 \\
3.02 \\
6.08 \\
1.01\end{array}$ & $\begin{array}{r}3.54 \\
\mathbf{3 . 3 4} \\
21.48 \\
24.74 \\
10.21 \\
5.90 \\
\mathbf{3 . 8 3} \\
\mathbf{9 . 9 0} \\
\mathbf{6 . 3 4} \\
\mathbf{3 . 7 1} \\
\mathbf{6 . 0 8} \\
.67\end{array}$ & $\begin{array}{r}4.20 \\
3.34 \\
18.86 \\
25.58 \\
12.53 \\
7.70 \\
4.09 \\
10.30 \\
5.68 \\
3.71 \\
5.17 \\
.67\end{array}$ & $\begin{array}{r}1.14 \\
2.78 \\
19.39 \\
24.19 \\
11.37 \\
6.90 \\
3.83 \\
10.40 \\
7.92 \\
2.78 \\
5.17 \\
1.01\end{array}$ \\
\hline &. & -5.0 & 6.0 & -6.0 & -2.0 & -6.0 & -0.0 & -7.0 & -7. & -0. & -5.0 & -8.0 \\
\hline
\end{tabular}

1 Looked for but not found: Ag, As, Au, B, Bl, Cd, Ge, In, La, Mo, Nb, Pb, Pt, Sb, Ta, Th, Tl, U, W, and $\mathrm{Zn}$.

1. Andesitic basalt, erupted from vent A on Feb. 28, 1955. Collected at Poholki road south of Honuaula cone, east Puna.

2. Andesitic basalt, Kil flow, erupted Mar. 3, 1955. Collected at coast road 1.6 miles north of Poholki, east Puna.

3. Basalt, Kaueleau flow, erupted Mar. 14, 1955. Collected at road near top of old sea cliff 1.4 miles southwest of Oplhikao, east Puna.

4. Basalt, Kaueleau flow, erupted Mar. 14, 1955. Collected in tidal zone at north edge of flow, $1.4 \mathrm{miles}$ southwest of Opihikao, east Puna.

5. Basalt, lava flow from westernmost vents, erupted about Mar. 20, 1955 . Collected at Pahoa-Kalapana road 5 miles south of Pahoa, east Puna.

6. Basalt, Keekee flow, erupted Mar. 25, 1955. Collected at coast road 3.1 miles southwest of Oplhlkao, east Puna.

7. Basalt, flow from vent $T$, erupted about Mar. 26, 1955. Collected just northeast of the Blowhole cone.

8. Basalt, Kehena flow, erupted Mar. 28, 1955. Collected at top of old sea cliff at coast road 3.7 miles southwest of Opihikao, east Puna.

9. Basalt, Kehena flow; erupted Mar. 28, 1955. Collected in tidal zone 3.7 miles southwest of Opthikao, east Puna.

10. Basalt, flow of May 25, 1955 . Collected 300 ft southwest of intersection of Kalapana and Kamaill roads, east Puna.

11. Basalt, lava flow of 1954 , on floor of Kilauea caldera northeast of Halemaumau.

12. A verage of 15 analyses of historic basalts and olivine basalts of Kilauea erupted prior to 1954 . (Analyses listed in Macdonald, 1955b, table 11, p. 32.) 
Through the early part of the eruption the lavas became progressively more mafic. All of the flows extruded in late March, April, and May are basalt.

Two pairs of analyses (columns 3-4 and 8-9, table 2) represent the same flows just before and after they entered the ocean. Two samples (columns 3 and 8) were collected at the level of the coastal road, respectively 25 and :55 feet.above sea level, and far. enough back from the line of the former sea cliff for the rock to be unaffected by sea water. The other two samples (columns 4 and 9 ) were collected below high tide level on the edge of the flows where they had built out into the ocean. "The purpose of the collections was to ascertain whether entrance of the flow into the ocean had any effect on chemical composition of the lava, particularly whether there was any increase in soda content that would cause the rock to trend toward the spilites in composition. The analyses demonstrate that there is no appreciable difference in composition between the two parts of the flows.

Figure 29 shows the changes in proportions of the major oxides in the lavas throughout the eruption. It is immediately apparent that the erupted lavas became progressively poorer in silica, iron, and alkalies, and richer in.lime and magnesia until late March. However, there is little difference between the lavas of late March and those of late May, although the latter are slightly poorer in magnesia and slightly richer-in soda and alumina than the former.

Among the minor elements, there is a slight increase in the average content of chromium and nickel and a slight decrease in that of barium; gallium; vanadium, and zirconium through the early part of the eruption.

Figure 30 is an ordinary variation diagram of the major oxides in the lavas of the 1954 and 1955 eruptions, in which the percentages of the other oxides are plotted against those of silica. The points for each oxide fall on a reasonably straight line; indicating that the rocks probably are all members of a simple consanguineous series. The points for the 1954 lava, in Kilauea caldera, also fall fairly close to the prolongation of the line defined by the points for the 1955 lavas. The major exception is the point for alumina in the 1954 lava, which falls well below the straight prolongation of the alumina line of the 1955 lavas. However, analyses of other groups of Hawaiian lavas:indicate a bend in the alumina line between 50 and 51 percent silica, bringing the line close to the point for the 1954 lava. 


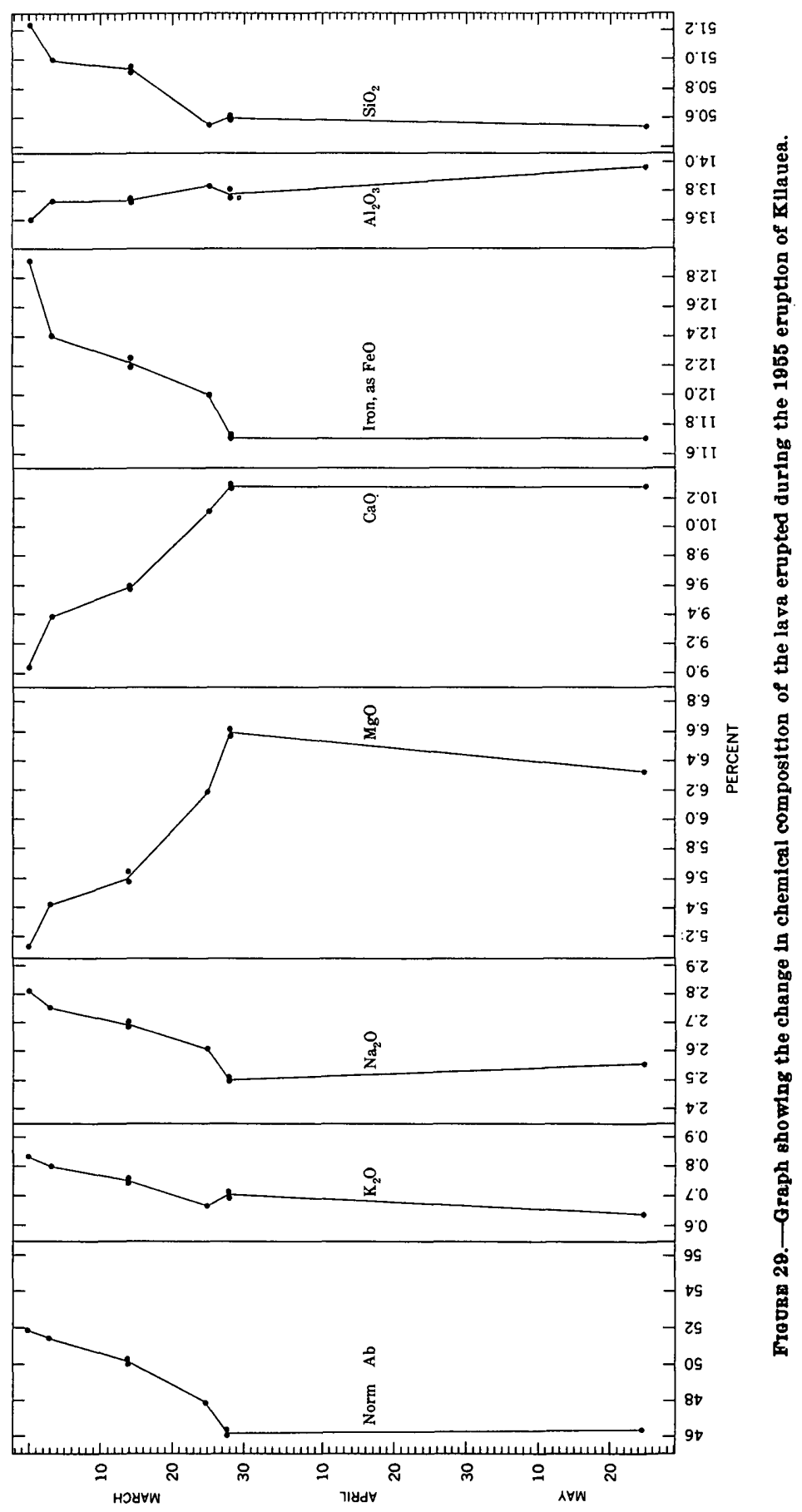


In figure 31 the lavas of the 1955 eruption are plotted according to the ratio of total iron as $\mathrm{FeO}: \mathrm{MgO}$ : total alkalies. . Also plotted in figure 31 are: the 1954 lava (column 11, table 2); the predominant pyroxene (augite) in the Uwekahuna laccolith, a shallow-seated intrusive body in the west wall of Kilauea caldera, the composition of which is given by Muir and Tilley $(1957$, p. 244); and olivine pheno-

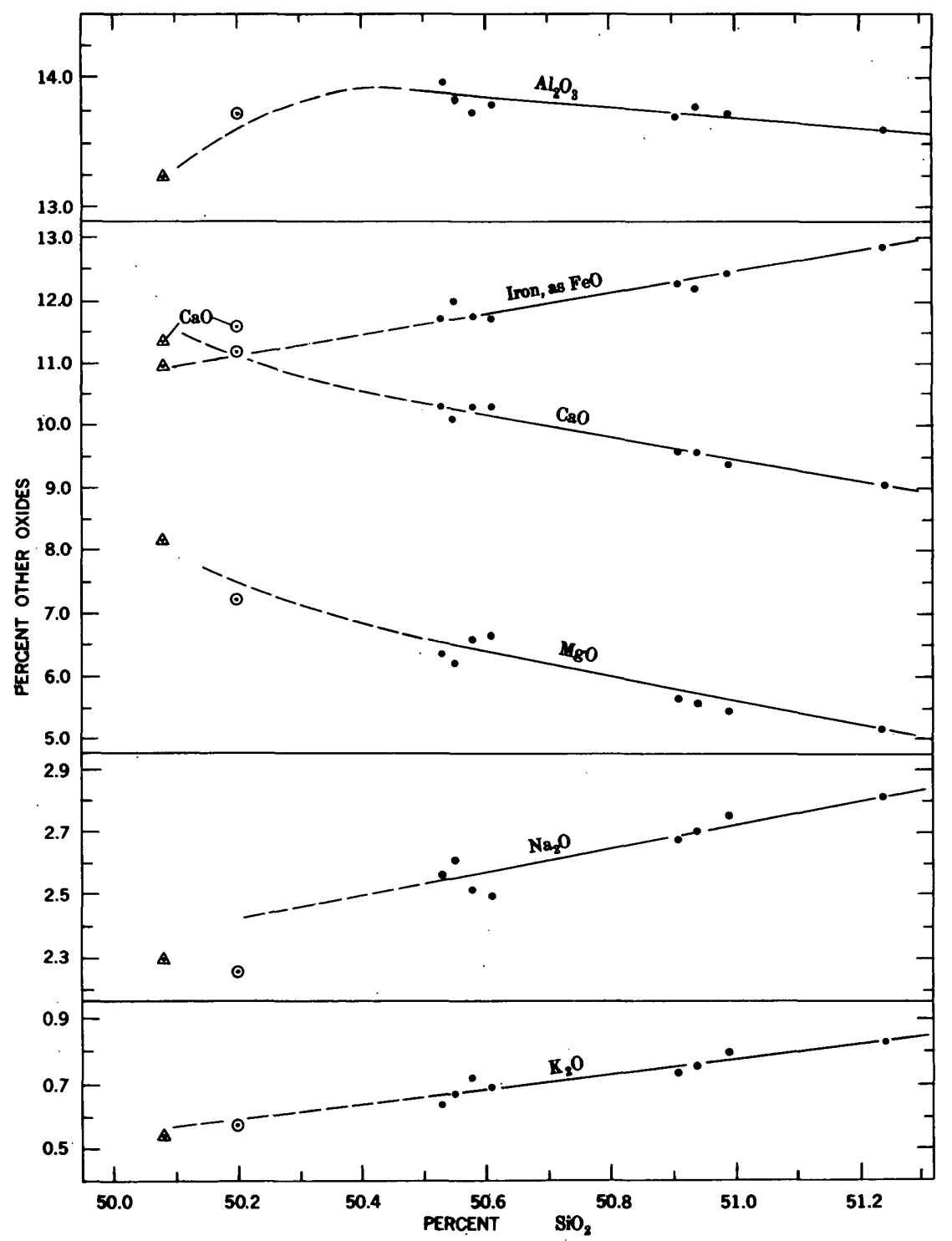

FrguRE 30.-Variation diagram of lavas of the 1954 and 1955 eruptions of Kilauea. Dots represent points for the 1955 lavas, circles those for the 1954 lava, and triangles those for the average of pre-1954 historic basalts and olivine basalts of Kilauea. 
crysts in the lava of the 1959 eruption (Richter and Eaton, 1960) analyzed by Takashi Katsura (Macdonald and Katsura, 1961). The points for the 1955 lavas fall quite well along a line that trends almost directly toward that for the olivine, suggesting strongly that the factor controlling the variations in composition of the 1955 lavas was the sinking of olivine phenocrysts in the magma. The compositional variation in lavas of the 1840, 1921, and 1959 eruptions also are shown, for comparison. It will be seen that the 1955 lavas constitute almost a continuation of the 1921 trend, and that the 1954 lava lies close to the same line. All of the trends are much alike and represent the general course of differentiation of Hawaiian tholeiitic magmas. The 1840 trend points less directly toward the olivine, and Muir and Tilley (1957) have shown that small amounts of pyroxene and plagioclase were involved with olivine in the differentiation of those lavas. On the other hand, the 1959 trend, like those of 1955 and 1921, points almost directly toward the olivine. In all three latter trends pyroxene crystallization probably exerted far less influence than in 1840. The markedly different slope of the 1959 and 1955-1921 trend lines may have resulted from movement of olivine crystals in parent magmas of slightly different alkali content.

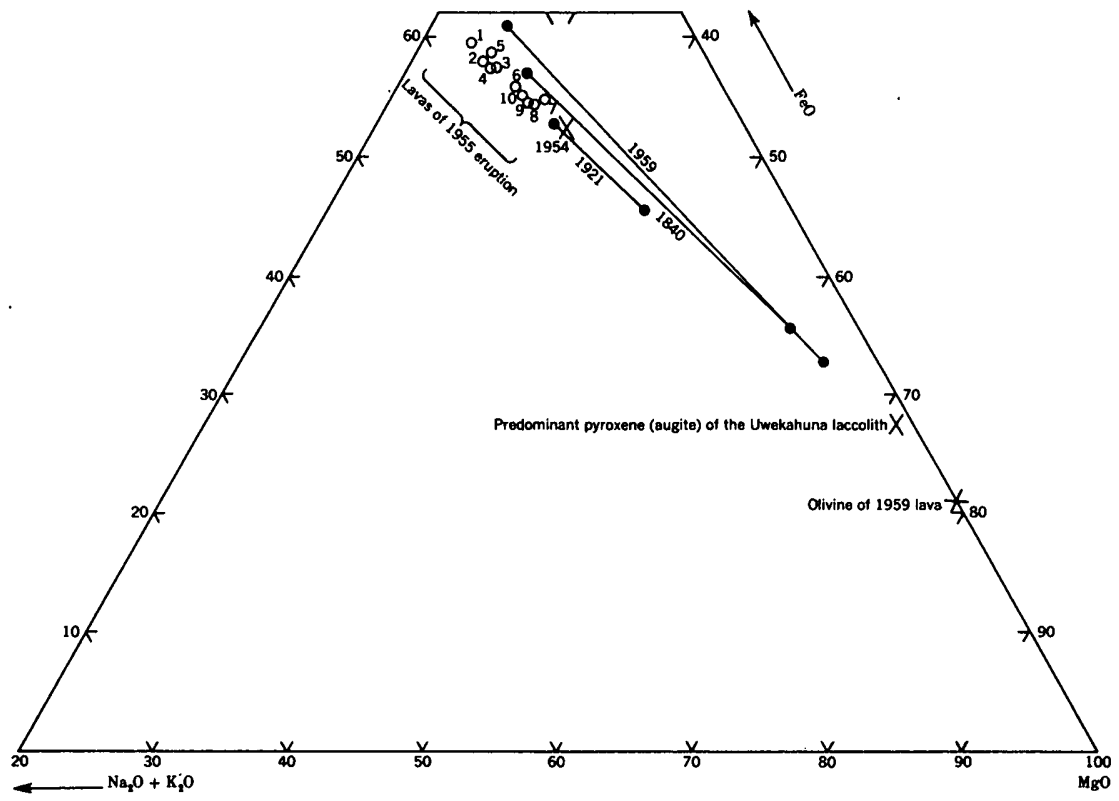

Figund 31.-AFM diagram of lavas of the 1955 eruption (open circles). The numbers correspond to those in table 2. The trends of lavas of the 1840 (Macdonald, 1944), 1921 (Tilley, 1960), and 1959 (Macdonald and Katsura, 1961) eruptions are shown for comparison. Also shown are the composition of olivine phenocrysts in the 1959 lava and the predominant pyroxene of the Uwekahuna laccolith. 


\section{SUBLIMATES}

Following the end of activity at most of the vents, small amounts of sulfur were deposited by rising gases on the walls of the vents and along cracks nearby. Similar very small deposits of sublimated sulfur formed also along cracks at the surface of lava flows at a few places remote from the vents. In a few areas sulfur deposition continued for many months after the eruption ended. The most conspicuous of these areas are at vent $R$ and just southwest of vent $M$ (pl. 1). In the latter area, cracks in a zone extending from vent $M$ nearly to vent $\mathrm{D}$ were still emitting sulfurous steam abundantly a year after the eruption ended. Sulfur was being deposited both on the ground and on the stalks of sugarcane killed by the gas.

Also, for several months after the flows poured out, gases escaping at places on the surface of the flows deposited white powdery sublimates. Samples of these were examined by W. F. Foshag, of the U.S. National Museum, and found to be sal-ammoniac. No ammonia and only very small amounts of chlorine have been found in gases of the eruption clouds in Hawaii (Jaggar, 1940). The ammonia to form the sublimates on the flows may have resulted from reaction of nitrogen with magmatic hydrogen, but more probably it was distilled from organic matter buried by the flow. Much or all of the chloride probably came from ocean spray blown inland by the trade winds and carried downward into the flows by infiltrating rainwater. Although ammonium chloride is a common sublimate at many continental volcanoes, it is rare in Hawaii, and both ammonia and hydrochloric acid are absent or present only in exceedingly small amounts in collections of Hawaiian volcanic gases.

\section{TEMPERATURE OF THE LAVA}

Temperature measurements were made on both lava fountains and the fronts of active flows with a Leeds and Northrup glowing filament type optical pyrometer, and a few measurements were made on lava flows with thermocouples. Optical pyrometer readings were made only at night, when there was no extraneous light. As in previous experience (Macdonald, 1955a, p. 85), it was found that very small amounts of volcanic fume or mist intervening between the object to be measured and the pyrometer resulted in readings that were too low. Any large amount of debris falling between the core of the lava fountain and the observer makes it difficult to match the color of the filament to that of the fountain core and tends to lower the apparent temperature. Because that condition is a very common one, most readings on lava fountains probably are somewhat too low. 
Except where black body conditions are approximated, a correction for emissivity theoretically should be. applied to the optical pyrometer readings to obtain the true temperature of the incandescent body. The emissivity correction for Hawaiian lavas has not been determined. However, readings on the fountain during the 1959 eruption approach the liquidus temperature for dry olivine basalt melts as determined in the laboratory by Yoder and Tilley (1957, p. 158), and since olivine phenocrysts were already present in the erupting lava this suggests that little correction of the readings is necessary. Except where otherwise stated, all of the temperatures given in the following paragraphs are uncorrected.

On the evening of February 28, readings on the cores of the lava fountains ranged from $1,010^{\circ}$ to $1,050^{\circ} \mathrm{C}$. The average of the readings was approximately $1,030^{\circ} \mathrm{C}$, but for the reason given above the higher readings probably were more nearly correct. Temperature readings made from a distance of only a few feet on freshly exposed brightly incandescent surfaces at the front of the advancing flow ranged from $930^{\circ}$ to $970^{\circ} \mathrm{C}$. The lava was in a state intermediate between pahoehoe and aa and was quite fluid. A pole could easily be pushed entirely through lobes 1 foot in diameter, and spectators were drawing out blobs. of the fluild lava and pressing coins into them for souvenirs. Some grottoes along the front of the flow gave temperature measurements up to $1,025^{\circ} \mathrm{C}$. Both these and the temperatures of the freshly exposed parts of the incandescent inner portion of the flow were confirmed by measurements with a Pyro disappearing-dot pyrometer. Flames were visible at some places, and the very high temperatures in the grottoes probably resulted largely from secondary heating by burning gases. Indeed, the high temperatures measured at this and other flow fronts may be partly the result of heating by combustion of gases derived from vegetation buried by the flow and by combustion of minor amounts of volcanic gases.

On the evening of March 2 the core of the lava fountain at vent $I$ gave readings ranging from $1,025^{\circ}$ to $1,030^{\circ} \mathrm{C}$, and the flow front, about 1,000 feet from the vents, gave temperatures averaging only $5^{\circ} \mathrm{C}$ lower.

The best measurements obtained on the lava fountains during the entire eruption were made on the night of March 15 at vent $S_{1}$. The fountain was about 200 feet high at the time and was jetting upward as an unwavering stream of incandescent liquid. The jet was slightly inclined southeastward, and nearly all of the cooling ejecta were falling southeast of the core of the fountain, leaving the view of the core almost unobstructed from the northwest side. At the 
same time, a light mist and cold wind from the north made it possible for us to approach within 200 feet of the northwest base of the fountain. Thus the fountain core was perfectly exposed to view, and there was no difficulty in filling the entire field of the pyrometer telescope. A series of nine readings by two observers from a distance of 300 feet ranged from $1,062^{\circ}$ to $1,078^{\circ} \mathrm{C}$ and averaged $1,066^{\circ} \mathrm{C}$. (A smaller fountain just southwest of the main one gave a reading of $1,078^{\circ} \mathrm{C}$.) From a distance of 200 feet, a series of 10 readings by 2 observers ranged from $1,068^{\circ}$ to $1,082^{\circ} \mathrm{C}$ and averaged $1,073^{\circ} \mathrm{C}$. The higher readings from the closer observation point suggest that the light mist was sufficient to cause some absorption of radiation and consequent reduction of the apparent temperature.

On the next evening, the fountain jet was more nearly vertical and a moderate volume of ejecta was falling on the northwest side of the fountain. Readings made from a point about 250 feet from the base of the fountain ranged from $1,025^{\circ}$ to $1,068^{\circ} \mathrm{C}$, but at least the lower ones were certainly too low because of the screening effect of the cloud of falling ejecta.

On the evening of March 20, readings on the very active front of an aa flow, from a distance of about 15 to 25 feet, ranged from $1,000^{\circ}$ to $1,040^{\circ} \mathrm{C}$. The readings were made on freshly exposed faces of the plastic core of the flow, but were difficult to make accurately because of the very rapid cooling and darkening of the freshly exposed surfaces.

On May 16, viewed from a distance of about 1,400 feet, the glowing throat of the spatter cone at vent $Z$ had a temperature of $1.055^{\circ} \mathrm{C}$ (three out of four readings); and the surface of a lava stream at the base of the cone, seen through a hole in the roof of the containing tube, had a temperature of approximately $1,075^{\circ} \mathrm{C}$.

On May 19, several readings on the plastic inner portion of the aa flow exposed in the very active front approaching the Iwasaki Camp averaged $1,050^{\circ} \mathrm{C}$, with some as high as $1,060^{\circ} \mathrm{C}$. Readings on incandescent fragments of aa clinker, rolling down the flow front, average about $1,020^{\circ} \mathrm{C}$.

On March 26, Prof. John J. Naughton, of the University of Hawaii, made temperature measurements with a recently standardized thermocouple at several places on the surface of the new lavas near the northwest base of the Blowhole cone in vent area $T$. The measurements were made in connection with the collection of gas from fumaroles. The temperature of the gas issuing from three of these fumaroles was $550^{\circ}, 600^{\circ}$, and $610^{\circ} \mathrm{C}$, (cold-junction correction added). In a tree mold approximately 1 foot in diameter and 4 feet deep the lower part 
of the wall was still glowing a dull red in daylight. The hot junction of the thermocouple was lowered to the base of the tree mold, and a temperature of $785^{\circ} \mathrm{C}$ was read. The flow appeared to be entirely stationary, but the underlying ground surface was nearly horizontal.

Possibly, on a greater gradient, with temperatures up to nearly $800^{\circ} \mathrm{C}$ in its interior the flow would still have been in motion.

Measurements were made with a Geological Survey thermocouple on small flows issuing around the base of the spatter conelet at vent $Z_{\bar{i}}$ on May 9. In the front of a small tongue of pahoehoe about 6 feet wide and 10 inches thick, about 25 feet from the base of the conelet, the temperature was approximately $950^{\circ} \mathrm{C}$ (cold-junction correction of $25^{\circ}$ added). The lava was still very fluid. A similar tongue spilled down a slope of $27^{\circ}$ at a rate of 60 feet per minute.

A few minutes later temperature measurements were made in a larger flow. The main feeding river of the flow was 5 feet wide and about 2 feet deep and was flowing about 10 feet per minute on a slope of only $1^{\circ}$ to $2^{\circ}$. With the hot junction of the thermocouple approximately 10 inches from the edge of the river and 6 inches below its surface, 15 feet from the base of the cone, the temperature was approximately $1,145^{\circ} \mathrm{C}$ (cold-junction correction of $50^{\circ}$ added.) About 35 feet farther from the cone a small tongue broke laterally from the same flow. The thermocouple probe was pushed into the moderately viscous lava, and a reading of approximately $870^{\circ} \mathrm{C}$ was obtained. However, conditions were less favorable for protection of the instrument, and the cold junction quickly became too hot (approximately $85^{\circ} \mathrm{C}$ but rising rapidly) to be held with comfort. The reading therefore had to be made very quickly and is doubtful. The lava tongue quickly became very viscous and stopped moving. Before the probe could be removed it was frozen solidly into the lava. The instrument was disconnected from it and the probe abandoned.

Many spots on the surfaces of the lava flows remained very hot for weeks or even months after the end of activity, apparently kept at high temperature by gases escaping from the lower parts of the flows. This was especially true in the area southeast of vent $Z$, where the flows from that vent accumulated on top of the earlier flows from vents $\mathrm{T}, \mathrm{W}$, and $\mathrm{Y}$, attaining a total thickness of more than 50 feet. A thermocouple measurement at one such hot spot at the edge of the new road across the flows, on November 23,1955 , indicated a temperature in the upper 6 inches of a clinker of approximately $488^{\circ} \mathrm{C}$.

After the end of the eruption, temperature measurements were made from time to time with mercury thermometers in the steaming vents in vent area $R$ and southwest of vent $M$. All of the readings were below the boiling point of water. No doubt the great excess of ground 
water available in this region prevents the emergence of superheated steam. Any superheated steam formed at depth by contact of water with hot rock is cooled on rising through ground water at higher levels, where the formation of additional steam would remove the excess heat.

\section{VISCOSITY OF THE LAVAS}

No direct measurements of the viscosity of the flowing lava were obtained. On several occasions, however, conditions were observed. that made possible calculation of the approximate viscosity through use of the Jeffreys formula for laminar flow, as was done during earlier eruptions (Macdonald, 1955a, p. 90). The greatest uncertainty involved in the calculation is the depth of the flowing stream. On one occasion the behavior of boulders rolling in the liquid indicated stream depth, and on two occasions the depth of the stream was obtained by probing with a pole. All other depths are merely estimates based on the appearance of the stream channel at low stages of flow and the behavior of the flowing liquid in it. The specific gravity of the flowing liquid also can only be estimated. In the calculations it was assumed to be 2.0. Because of these uncertainties in the data, the viscosities calculated represent only orders of magnitude.

On the afternoon of May 23 an attempt was made to check the viscosities calculated from observed speeds of flow in channels by means of a crude penetrometer. A small lava stream was issuing from a vent on the foot of cone $T$ and flowing northeastward through a tube. A small hole in the roof of the tube gave a view of the stream, but the roof afforded sufficient protection from the radiant heat from the surface of the stream to allow us to stand over the stream and work through the hole. The temperature in the tube, estimated by color to be about $1,100^{\circ} \mathrm{C}$., was high enough to cause some remelting and dripping of the roof. The stream in the tube was approximately 5 feet wide and was flowing at a speed of 6 inches per second down a slope of approximately $3^{\circ}$. A pole was cut of green wood and sharpened on one end to a crudely rounded point. The pole was 8 feet long and 1.5 inches in diameter at the sharpened end. Probing the lava stream with the pole showed that the liquid was 12 inches deep and was underlain by a layer of still liquid but more viscous material about 1 inch thick. There was no sign of a surface crust or skin more viscous than the material beneath it, presumably because the reverberatory effect in the tube kept the surface as hot as the liquid beneath it. The viscosity was calculated on the basis of speed of flow and channel dimensions to be on the order of $2 \times 10^{3}$ poises. The pole was then held in vertical position and allowed to sink under its own weight $(1,300$ 
grams) into the liquid, and the rate of sinking was found to be 5 inches in 4 seconds. The order of magnitude of the viscosity calculated from this experiment was $1 \times 10^{3}$ poises. Considering the crudity of both calculations, the agreement is surprisingly good.

Table 3 lists the calculated viscosities and other data on the flows. The temperatures given in the table are only estimates. No actual temperature measurement was obtained in the same lava stream for which viscosity calculations were made. Reliable optical pyrometer readings can be made only at night, when conditions for observing the other factors involved in the viscosity calculations are poor, and at none of the places where data for viscosity calculations could be obtained were conditions suitable for the use of the thermocouple. One of the temperatures listed in table 3 was obtained with the thermocouple at a nearby flow that was closely similar to the one for which the viscosity was calculated, but all of the others are only estimates based on the color of the fluid portion of the lava in daylight. On May 17, 19, and 23 the surface of the lava river was too much covered with clinkery crust to permit an estimate of the temperature of the interior portion, but on incandescent portions of the front of a small tongue that overflowed from the channel the temperature was estimated to be about $950^{\circ} \mathrm{C}$.

In a general way, the viscosity. unquestionably increases with decrease of temperature and increase of distance from the vent. This is better shown by data from earlier eruptions (Macdonald, 1954a, $\mathrm{p}$. 170-173). However, factors in addition to temperature probably are involved.

TABLE 3.-Viscosity of flowing lava during the 1955 eruption

\begin{tabular}{|c|c|c|c|c|c|c|c|c|c|}
\hline \multirow{2}{*}{ Date } & \multirow{2}{*}{ Time } & \multirow{2}{*}{ Location } & \multirow{2}{*}{$\begin{array}{l}\text { Dis- } \\
\text { tance } \\
\text { from } \\
\text { vent } \\
\text { (feet) }\end{array}$} & \multicolumn{3}{|c|}{$\begin{array}{l}\text { Approximate dimen- } \\
\text { sions of flow or } \\
\text { channel }\end{array}$} & \multirow{2}{*}{$\begin{array}{c}\text { Speed } \\
\text { of } \\
\text { flow } \\
\text { (ft. } \\
\text { per } \\
\text { sec.) }\end{array}$} & \multirow{2}{*}{$\begin{array}{c}\text { Calculated } \\
\text { viscosity } \\
\text { (poises) }\end{array}$} & \multirow{2}{*}{$\begin{array}{l}\text { Est1- } \\
\text { mated } \\
\text { tem- } \\
\text { pera- } \\
\text { ture } \\
\left({ }^{\circ} \mathrm{C}\right)\end{array}$} \\
\hline & & & & $\begin{array}{c}\text { Width } \\
\text { (feet) }\end{array}$ & Depth & slope & & & \\
\hline $\begin{array}{ll}\text { April } & 6 \\
\text { May } & 9 \\
\text { May } & 9 \\
\text { May } 17\end{array}$ & $\begin{array}{l}17^{\mathrm{h}} \\
13^{\mathrm{h}} 0^{\mathrm{m}} \\
14^{\mathrm{h}} 35^{\mathrm{m}} \\
133^{\mathrm{h}} 30^{\mathrm{m}}\end{array}$ & $\begin{array}{l}\text { River of Kehena flow } \\
\text { Small flow at vent } Z \\
\text { Small fow at vent } Z \\
\text { Cascade in river of flow from } \\
\text { vent } Z\end{array}$ & $\begin{array}{r}2,000 \\
50 \\
70\end{array}$ & \begin{tabular}{r|}
15 \\
6 \\
4
\end{tabular} & $\begin{array}{l}5 \\
1 \\
2\end{array}$ & $\begin{array}{r}5^{\circ} \\
27^{\circ} \\
24^{\circ}\end{array}$ & $\begin{array}{l}2.5 \\
1.0 \\
2.0\end{array}$ & $\begin{array}{l}\text { 1. } 6 \times 10^{4} \\
6.2 \times 10^{3} \\
1.1 \times 10^{4}\end{array}$ & $\begin{array}{r}900 \\
1927 \\
900\end{array}$ \\
\hline $\begin{array}{l}\text { May } 17 \\
\text { May } 19\end{array}$ & $\begin{array}{l}14^{\mathrm{h}} \\
14^{\mathrm{h}} 10^{\mathrm{m}}\end{array}$ & $\begin{array}{l}\text { River of flow below cascade. } \\
\text { River of small flow from } \\
\text { vent } \mathrm{Z}\end{array}$ & 2,500 & 25 & 14 & $3^{\circ}$ & $\begin{array}{l}10.0 \\
5.7\end{array}$ & $\begin{array}{r}\times 10^{3} \\
\times 10^{3} \\
\times 10^{4}\end{array}$ & 0 \\
\hline May 19 & $14^{\mathrm{h}} 20^{\mathrm{m}}$ & $\begin{array}{l}\text { Small overflow from river } \\
\text { channel. }\end{array}$ & 2,500 & $\begin{array}{l}10 \\
25\end{array}$ & 8 & 5 & $\begin{array}{l}4.0 \\
1.9\end{array}$ & $\begin{array}{l}1.0 x \\
1.0 \times\end{array}$ & 950 \\
\hline $\begin{array}{l}\text { May } 23 \\
\text { May } 23\end{array}$ & $\begin{array}{l}11^{\mathrm{h}} 30^{\mathrm{m}} \\
14^{\mathrm{t}} 30^{\mathrm{m}}\end{array}$ & $\begin{array}{l}\text { River of flow from vent } \mathrm{Z} \\
\text { Stream in lava tube near }\end{array}$ & 4,800 & 15 & $:$ & 40 & 37 & $2.6 \times 10^{4}$ & 100 \\
\hline May 24 & $14^{\mathrm{b}}$ & $\begin{array}{l}\text { base of cone } T \\
\text { Cascade at edge of pond fed } \\
\text { by vent } Z\end{array}$ & $\begin{array}{c}(?) \\
1,000\end{array}$ & $\begin{array}{r}5 \\
10\end{array}$ & $\begin{array}{l}1 \\
3\end{array}$ & $\begin{array}{r}3^{\circ} \\
30^{\circ}\end{array}$ & $42^{.5}$ & $\begin{array}{r}2.0 \times 10^{3} \\
2.5 \times 10^{3}\end{array}$ & $\begin{array}{l}1,100 \\
1,050\end{array}$ \\
\hline
\end{tabular}

1 Thermocouple measurement on a similar flow a few feet away.

2 Calculation based on rate of sinking of a pole into the liquid gives a value of $1 \times 10^{3}$ poises. 


\section{FORMATION OF THE PIT CRATER}

Pit craters are formed chiefly by collapse of the ground surface and consist of circular to elliptical pits with nearly vertical walls surrounded by no mound of accumulated lava or pyroclastic materials. They are fairly common features on both Kilauea and Mauna Loa. Their mode of formation has been deduced from their structural relationships and from theoretical considerations (Wentworth and Macdonald, 1953, p. 19-21). Although two pit craters (Lua Hohonu and Lua Poholo) are believed to have formed in the summit region of Mauna Loa during historic time and the later stages of enlargement of the Devil's Throat, a small pit crater on the east rift zone of Kilauea, have been observed, the actual formation of a pit crater has never before been witnessed.

The eruptive activity on March 13 left a row of small spatter cones extending across cleared fields just northeast of the Pahoa-Kalapana road, in vent area $R_{5}$ (fig. 4). Lava activity at the adjacent vent $R_{7}$, on the road, continued for several days, but after the afternoon of March 13 there was no further lava extrusion at vent $R_{5}$, although fuming continued. On March 17 new cracks were noticed in the road pavement and in adjacent ground west of vent $R_{5}$. These cracks trended more nearly north-south than the earlier cracking parallel to the rift zone. On March 18 the main crack in the road was 6 inches wide, and the ground surface east of it had sunk 3 to 4 inches. Similar but smaller movement occurred on other nearby cracks. Sulfurous fume was seeping from the cracks.

At $16^{\mathrm{h}} 03^{\mathrm{m}}$ on March 20, while we were watching the advance of a lava flow about a mile to the south, we heard a sharp explosion and saw a black cloud rise to a height of about 500 feet over vent area $R$. Shortly afterward Captain Chaney, National Guard pilot, reported a brightly glowing hole at vent $\mathbf{R}_{5}$. The hole was nearly circular, and estimated to be about 20 feet in diameter. From the air, Chaney could not discern the bottom of it, probably because of the very bright glow from the walls. The perforation of the crater to the surface undoubtedly occurred at the time of the explosion at $16^{\mathrm{h}} 03^{\mathrm{m}}$. Several other smaller explosions occurred during the next few hours, and at $17^{\mathrm{h}} 20^{\mathrm{m}}$ one of the Civil Defense wardens reported that a small amount of fine cinder was being wafted upward from the crater. None of the explosion clouds contained any large volume of ejecta. During the night a tongue of pale-blue and yellow flame 15 to 20 feet high played over the crater mouth.

On the morning of March 21 we examined the crater from the air. It was about 20 feet in diameter at the surface and 50 to 75 feet deep and was floored with brightly glowing material that appeared to be 
solid rather than liquid. The cavity increased in diameter downward, the walls overhanging 15 to 20 feet on all sides except the southwest, where the chamber extended back at least 50 feet beyond the crater rim. The new cracks in the road and adjacent ground were concentric to the crater, and obviously had formed by settling and tilting of the surrounding surface toward the crater.

Ground examination on March 22 showed the crater opening to be a little larger than on the previous day. It was about 25 feet in diameter. The ground around it was covered with a thin layer of black glassy ejecta, including many Pele's tears (frozen glass drops). The volume of ejecta, however, was infinitesimal compared to the volume of the crater.

There was no evidence that the magma had ever risen in the crater to levels visible on March 22 or later. Part of the wall of the crater was covered with festooned sheets of congealed lava (fig. 14), but theise lava draperies did not resemble the continuous coating of lava left on the wall of a crater by draining away of a lava pool. Instead, they appeared to be the result of local drip of the rock surface fused by intense heat, similar to the drip tapestries in blowing cones and gasheated grottoes at the edge of lava lakes. The coatings obviously were formed after the opening of the crater to the surface, since they covered parts of the wall to within about 4 feet of the crater rim. The coatings on the crater wall were minor in amount, however. The wall consisted largely of the freshly fractured ends of older lava beds. The crater probably was formed by mechanical removal of the old (solid) rock.

Unfortunately, conditions did not permit good pyrometer readings on the walls of the crater. Frequent collapse made it risky to go close to the crater rim even in daylight, and too risky to do so at night. However, the incandescent glow from the crater walls was yellower than that from the core of the lava fountains, indicating a temperature even higher than that of the latter. This excess of heat, sufficient to produce minor fusion of the edges of the old lava beds exposed in the crater. walls, almost unquestionably was the result of combustion of the escaping gases.

During the following days the crater opening grew :steadily larger as the rim collapsed, particularly on the southwest side, and the amount of overhang of the walls was reduced. The floor of the crater was covered with fragments of rock fallen from the rim and walls. In the northeast and southwest walls an irregular dike 1 to 2 feet thick led upward to the remains of the line of spatter cones, and obviously represented the congealed feeder of the March 13 eruption. 
From the relatively minute volume of ejecta thrown out, it is clear that the crater was not formed by explosion. It must have resulted largely from collapse caused by withdrawal of support from beneath. It is unlikely that an upward-tapering cavity of the form shown by the original crater opening would result from funneling of broken rock down into a narrow fissure such as that represented by the dike in the crater walls. The shape of the original cavity is strongly reminiscent of the form deduced mathematically by Anderson (1924) for ring dikes, and thus appears to indicate subsidence into an underlying magma body or void at least as great in horizontal dimensions as the visible bottom of the crater. In some way the narrow dike must have become locally expanded to a magma body more than 50 feet wide. No such distension of the overlying surface took place; therefore the enlargement must have been by removal of the rock material of the dike walls, either by stoping or by melting. Several pipelike intrusive bodies, of the sort envisioned beneath the crater, have been found in the older dissected Hawaiian volcanoes (Daly, 1911, p. 99; Stearns and Macdonald, 1942, p. 164).

It is noteworthy that the site of the crater was not one of major outpouring of lava at any stage of the eruption. The enlargement of the underlying magma body did not depend on corrosion or corrasion of the walls of the conduit by long-continued passage of magma upward through it. Pure melting appears to be a more probable mechanism for the local enlargement than mechanical removal of the older rock, and the heat to bring about such melting seems most likely to have come from reaction of gases, either still enclosed in the magma or in a sort of combustion chamber just above it. Thus the enlargement of the conduit to form a local pipelike body probably was largely the result of melting of the walls, aided to some extent by stoping. The process is that of gas blowpiping long advocated by Daly (1911, p. 85-90) and others.

Collapse of the roof due to lack of support resulted in formation of the projectile-shaped chamber above the magma mass. The roof was left unsupported either because of withdrawal to greater depths of the underlying magma body or simply because of the difference in density of the magma and its roof rocks. If, however, the roof had merely sunk into the underlying magma it might be expected to displace upward an equal volume of the magma, causing molten lava to rise in the potential crater opening. Because there is no evidence that this occurred, and also because of the rather small difference in density of the magma from the gross density of the overlying rocks, it appears more likely that the subsidence resulted from a withdrawal of the 
magma similar to the one that allowed ground water to enter the hot conduits on March 1.

Withdrawal of the magma and collapse of the roof of the magma chamber along ring-dike fractures may for a short time have resulted in an open gas-filled chamber above the magma body. Finally, perforation of the roof of the chamber released the imprisoned gas, causing the puff of black ash-laden fume seen by us on the afternoon of March 20. Thereafter the history of the crater consisted in a caving back of the walls toward a position of equilibrium.

\section{GROUND MOVEMENTS ACCOMPANYING THE ERUPTION}

\section{MOVEMENTS IN EAST PUNA}

It has long been known that eruptions of the Hawaiian volcanoes commonly are preceded by tumescence of the volcanic structure (Jaggar, 1930). It has also been believed, though on less firm grounds, that sinking of the summit region, sometimes accompanied by collapse in the caldera, may accompany draining of the underlying magma into the rift zones, with or without surface eruption.

The 1955 eruption furnished unusually good data on both types of movement. At the time of the outbreak surveys were in progress for the construction of a new highway southwest of Kapoho. A line of differential levels had been run along the route, which crossed the zone of eruptive fissures at a.low angle, and second order triangulation had been done for the establishment of land boundaries. Both surveys had been carried out less than 3 months before the eruption. After the eruption both surveys were repeated. The differences between the two sets of surveys indicated both horizontal and vertical movements of several feet.

Movements in east Puna were also shown by ground-surface tilting measured by means of the horizontal pendulums in the Pahoa seismograph station. Some shift of the pendulums undoubtedly was the result of seasonal temperature change both on the building housing the instrument and on the surrounding region, but a larger amount unquestionably was related to volcanic changes. The shift of the pendulum over a period of a little more than 2 weeks preceding and accompanying the beginning of the eruption was much more than it had been over several preceding months. Furthermore, the calculated rise of the ground surface near the rift zone indicated by the pendulum shift, assuming that it was caused by actual regional tilting of the ground, checks well with the amount of change indicated by differential leveling.

Locally, along the rift zone vertical changes were so great that they were easily seen without the aid of instruments. Fault scarps 
up to 5 feet high were formed. These changes were measured with ordinary scales or by peg leveling.

Figure 32 shows the pattern of the eruptive fissures during the eruption. In the northeast group the fissures are arranged en echelon, each one offset to the left in relation to the preceding one. This pattern immediately suggested that the fissures might be a series of gash fractures, or fractures of related type, pulled open by horizontal right-lateral displacement in the underlying rocks. In the later phase of the eruption, the fissures of the southwest group were again arranged en echelon, but with the offset to the right. If they were gash fractures, the horizontal shift in the underlying rocks must have been opposite in sense to that during the earlier part of the eruption.

A reversal in the direction of horizontal shear on the rift zone between the early and late phases of the eruption appears unlikely. Moreover, a study of first motions of the ground during earthquakes associated with the eruption indicates dip-slip rather than strikeslip movement on the fissure zone (see section on "Earthquakes Preceding and Accompanying the Eruption") and the surveys before and after the eruption indicate that, in the northeast area at least, there was no horizontal movement parallel to the rift zone. The cause of the en echelon arrangement of the eruptive fissures remains unknown.

Tilting of the ground surface measured in the north-south azimuth at the Pahoa seismograph station is shown in the upper part of figure 33. The station is located north of the east rift zone of Kilauea, westnorthwest of the northeast group of eruptive fissures active from February 28 to March 6, and nearly north of the central part of the southwest group of fissures active from March 12 to May 26. The graph indicates that moderately rapid northward tilting of the ground commenced on February 26 (2 days before the outbreak), increased on February 27, and continued at a somewhat lesser rate on February 28 and March 1 . Virtually no tilting occurred between March 1 and 6, but a sharp southward tilting occurred during the 3 days following the cessation of lava extrusion on March 6 . On March 9 rapid northward tilting resumed and continued until the outbreak of March 13. The northward tilting at Pahoa is interpreted to indicate a rise of the ground surface along the rift zone resulting from inflation of the rift zone by introduction of new lava at depth. The inflation was accompanied by about 3,400 earthquakes in the period from March 6 to 12, which are believed to have resulted from the splitting open of the rift zone. Following the outbreak of lava on March 13 there was only minor oscillation of ground tilt throughout the remainder of the eruption. 
THE ERUPTION IN EAST PUNA

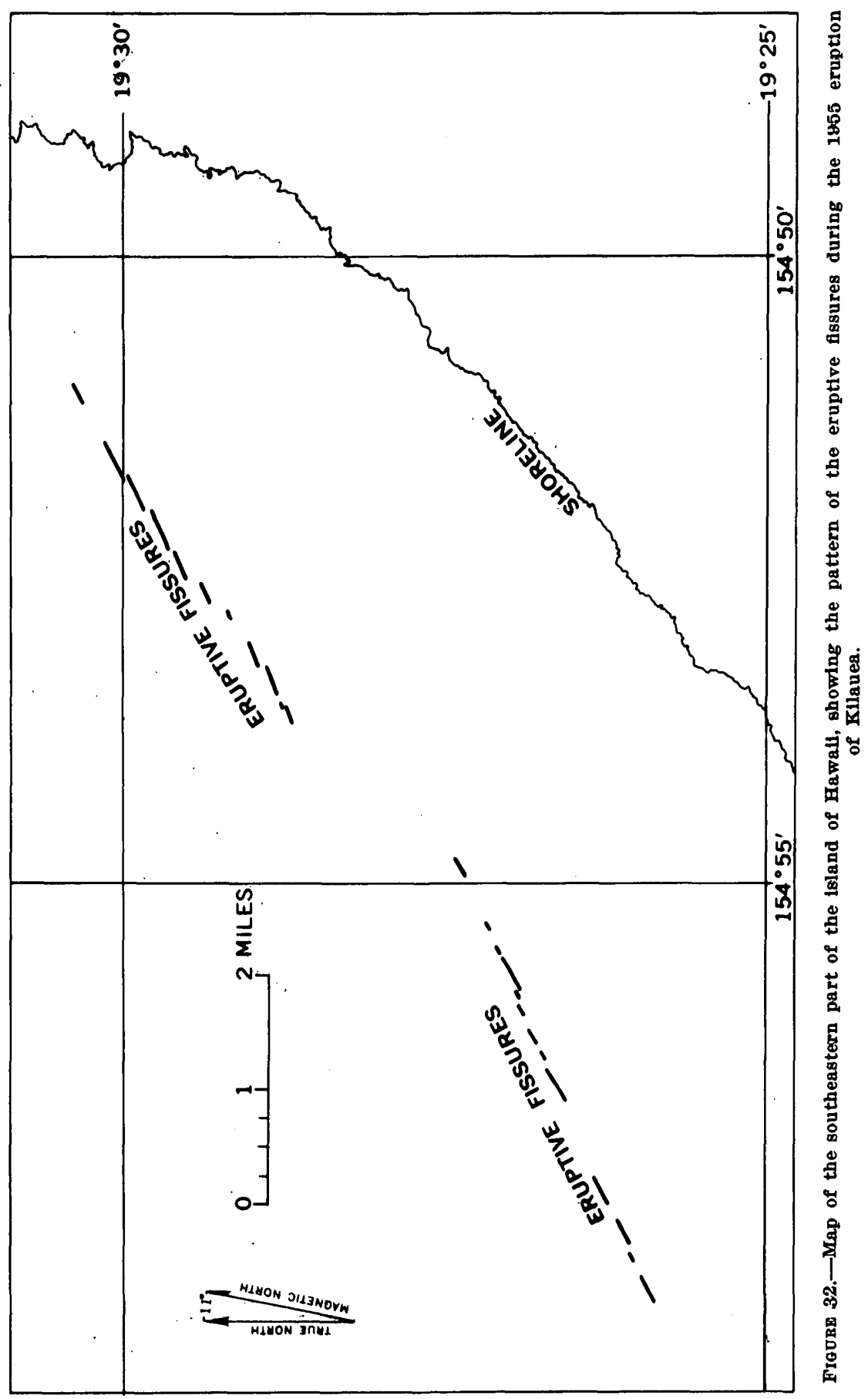




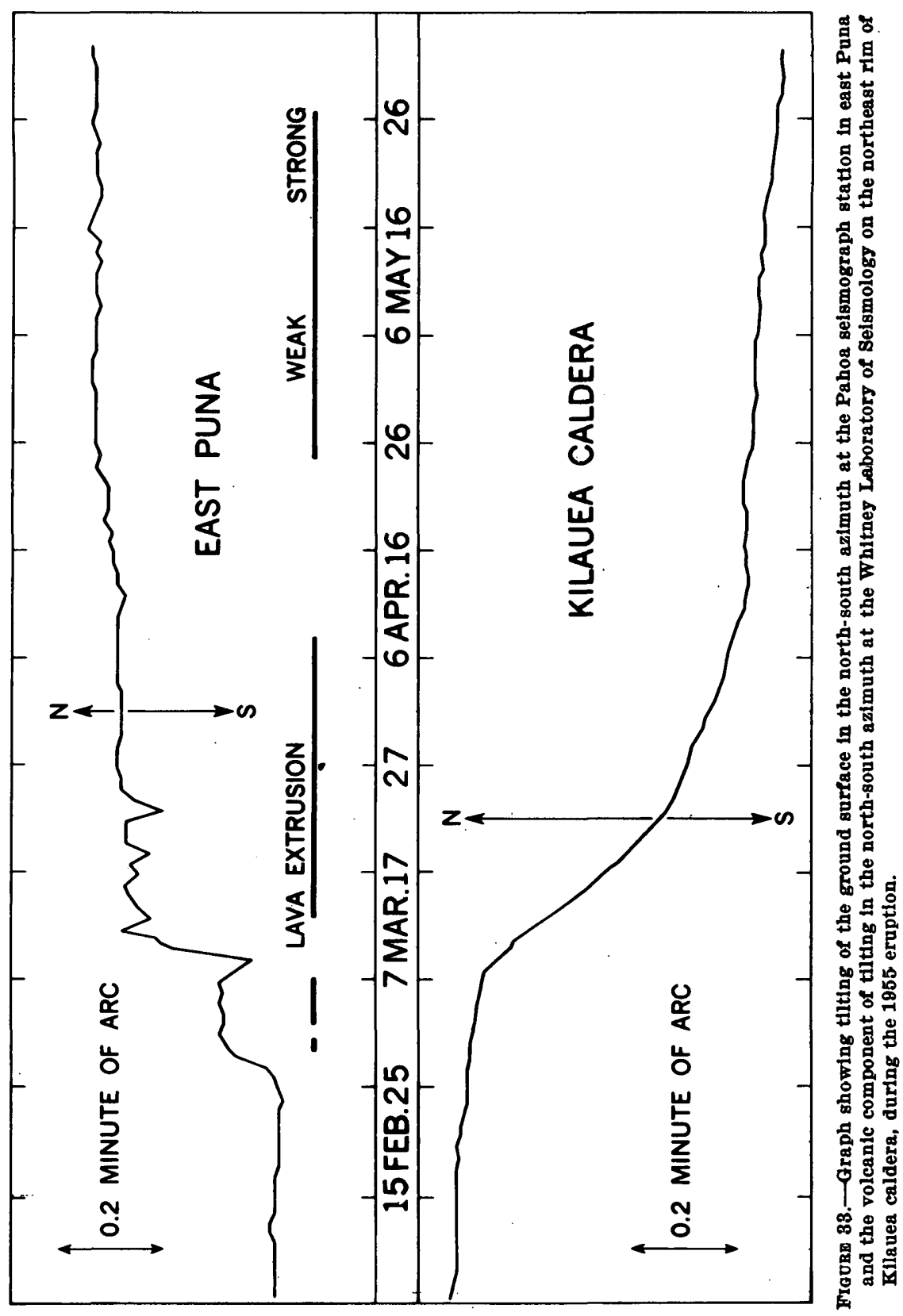


The northward tilting at Pahoa between February 26 and March 13 totaled approximately 16 seconds of arc. Assuming a uniform rise from the Pahoa station to the zone of eruptive fissures south of it, this indicates an uplift of the ground surface at the rift zone with respect to the Pahoa station of approximately 1 foot. However, tilting at Pahoa probably was less than the average tilting between Pahoa and the rift because the hinge line must have lain some distance north of Pahoa and the rate of uplift may be expected to decrease with distance from the point of maximum uplift. Thus the absolute uplift at the crest of the rift zone south of Pahoa must have been somewhat more than 1 foot.

Although there was a general rise of the crest of the rift zone, subsidence occurred immediately along the zone of eruptive fissures. Fault scarps.crossing the highway 3.5 miles south of Pahoa (just south of the flows from vent $R_{6}$ ), with offset up to about 18 inches, marked the south edge of a narrow graben. The north edge of the graben, just north of vent $R_{\imath}$, was a zone of flexure marked by a series of open cracks but without any true faulting. (Fault scarps that later developed in that area were related to the collapse of the pit crater at vent $R_{5}$, not to the graben along the crest of the rift zone.)

Changes in the elevation of bench marks during the eruption indicate the same sort of vertical movements in the area around the northeast group of eruptive fissures that ground tilting indicates around the southwest group. Figure 34 shows the changes in elevation of bench marks between the two surveys respectively preceding and following the eruption. The changes are in relation to the bench mark at the junction of the Kapoho and Pohoiki roads (triangulation station at the left edge of the diagram), and since that bench mark also presumably was uplifted to some degree the absolute rises of other bench marks in relation to sea level would have been even greater than that indicated by the figures. Eastward from the road junction the bench marks were found to have risen by progressively greater amounts to a maximum uplift of 0.92 feet at bench mark 6 , approximately 8,300 feet east-northeast of the road junction and 2,000 feet north-northwest of the trace of the zone of eruptive fissures. Presumably the amount of uplift continued to increase toward the fissure zone, but there were no bench marks between bench mark 6 and the fissure zone to demonstrate the fact. The next bench mark is only about 200 feet from one of the major eruptive fissures and is already within the zone of graben collapse along the crest of the rift. It showed an uplift. in relation to the bench mark at the road junction of only 0.26 feet. A short distance beyond it a fault scarp 


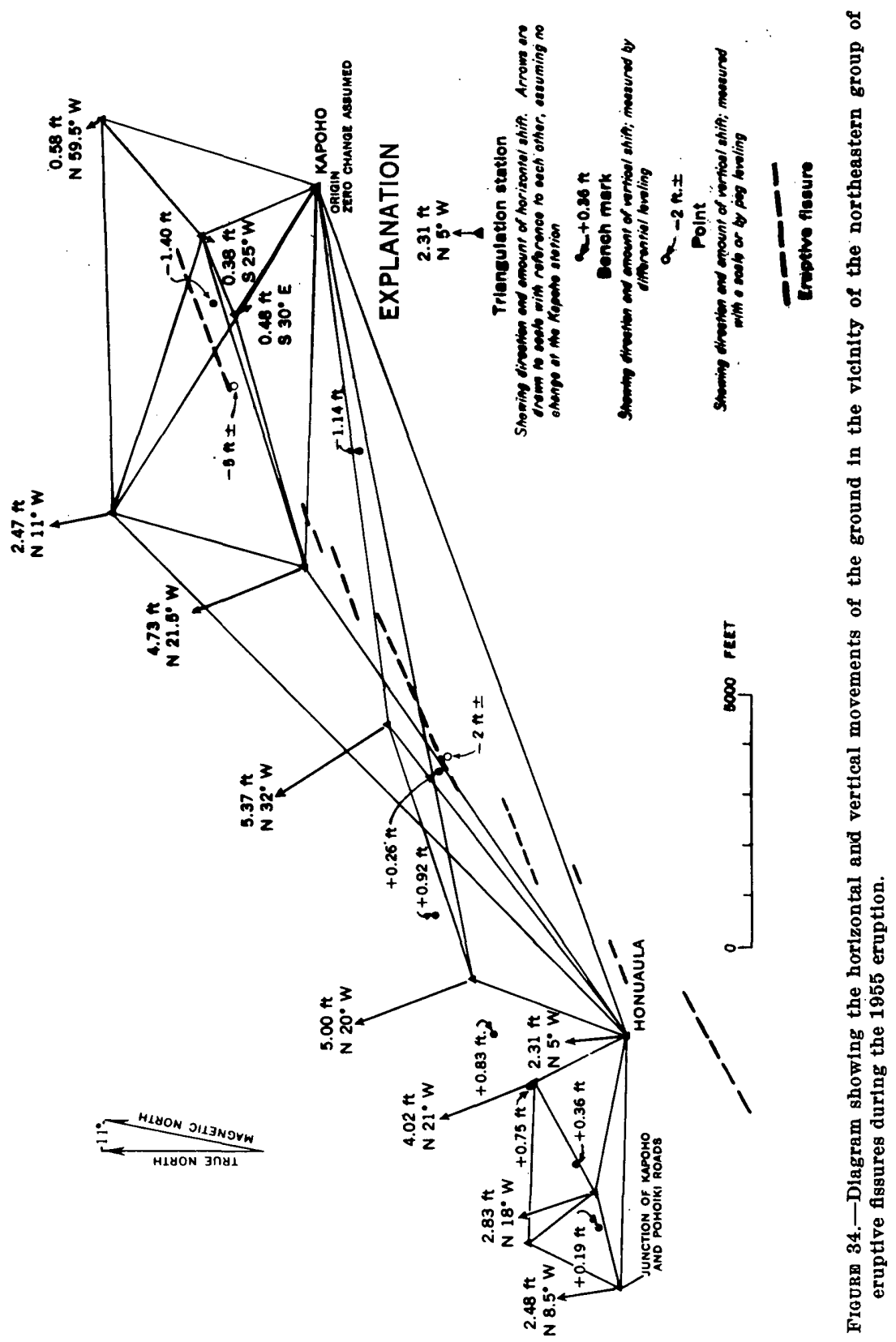


across the road dropped the ground to the southeast more than 2 feet. The fault scarp, and bench marks along the old road for the next 5,000 feet eastward, were later buried by lava.

Nearer Kapoho, leveling along the highway showed a lowering of the ground surface of 1.14 and 1.40 feet at bench marks T-27 and 13 respectively. Just south of the eruptive fissure on the western outskirts of Kapoho (vent $\mathrm{P}$, pl. 1), a fault along the south side of a small graben had an offset of about 5 feet. The north side of the graben was hidden by new lava flows, and lava banked against the fault scarp on the south side, partly hiding it.

The relative horizontal shifts of triangulation stations in the northeast area between the survey preceding the eruption and that following it also are shown in figure 34. Comparison of the two surveys was based on the assumption that the line between primary triangulation stations Keaau and Kaloli 2, about 15 miles north of the eruption area, remained unchanged. Retriangulation of a large net including those stations indicated that the Kapoho and Honuaula stations had shifted by an amount less than the expected error of the survey. : It is justifiable, therefore, to assume that the Kapoho station, the only station in the local triangulation net that lies south of the zone of eruption fissures, remained unchanged in position.

Assuming the position of the Kapoho station to have remained constant, the larger scale local resurvey after the eruption showed all of the stations northwest of the fissure zone to have shifted northwestward, and all but one in a direction normal to the trace of the fissure . zone. The single exception is the Honuaula station, which lies nearly on the fissure zone, and which shifted in a direction $65^{\circ}$ from the general alinement of the fissure zone. The amount of horizontal displacement ranged at most stations from 2.31 to 5.37 feet. The station 4,600 feet north-northeast of the Kapoho station shifted only 0.58 feet, but it is within the fissure zone. Two stations lying between the Kapoho station and the eruptive fissure also are within the fissure zone. They shifted southeastward and southwestward respectively 0.48 and 0.38 feet, indicating that stations close to the south-edge of the fissure zone shifted southward more than did the Kapoho station, which was farther from the fissure zone.

The shifts in relative positions of the triangulation stations indicate a simple pulling open of the fissure zone. Although there appears to have been some minor irregular shifting of blocks within and very close to the zones of fissures, the movement was almost entirely at right angles to the general trend of the fissure zone, with little or no general movement parallel to the zone. A similar distension of the ground 
surface across the general trend of the fissure zone has been observed in other eruptions, notably thase of Sakurajima in 1914 and Miyakesima.in 1940 (Mogi, 1958, p. 107-108, 128-129).

Thus both ground tilting and differential leveling indicate a tumescence of the rift zone in eastern Puna, resulting in a rise of the ground surface of at least 1 foot. The rise appears to have taken place in two spasms, corresponding with the great earthquake swarms preceding outbreaks respectively on the northeast and southwest groups of eruptive fissures, and to have terminated at the beginning of lava extrusion. Probably at the same time there occurred a distension of the surface, representing a spreading of the rift zone of as much as 5 feet. No doubt a similar spreading has occurred with the intrusion of every dike of the thousands that make up the dike complexes that occupy the rift zones at depth (Wentworth and Macdonald, 1953, p. 89-91). Starting shortly before the outbreak of lava and continuing during the lava activity, there was slight sinking of a series of narrow grabens along the fissure zone, as though the stretching of the rift-zone arch had permitted the settling of a keystone block along its axis.

\section{GINKTNG IN THE KILA UEA SUMMIT REGION}

Beginning in January 1953, measurements at the Whitney Laboratory of Seismology on the northeast rim of Kilauea caldera (fig. 46), showed gradually cumulative tilting of the ground surface away from the center of the caldera, indicating tumescence of the summit region of the volcano. The tumescence, which is believed to reflect an increase of magmatic pressure beneath the region, was not appreciably affected by the brief eruption in May and June of 1954 . By late January 1955, cumulative northward tilting at the Whitney Laboratory amounted to approximately 20 seconds of arc. Assuming the tilting to extend only as far as the Whitney Laboratory, the amount of rise of the ground surface northeast of Halemaumau between January 1953 and January 1955 was approximately 0.9 foot. Actually, the rise must have been more than that because the tilting unquestionably extended beyond the measuring station.

The first part of the eruption in east Puna produced no recognizable reaction in the Kilauea caldera region. On March 7, however, a rapid centripetal tilting began at the stations on the northeast and west rims of the caldera, indicating subsidence of the caldera floor and probably of the entire summit of the mountain. The beginning of sinking corresponded approximately in time with the beginning of the second great series of earthquakes, which apparently was caused by tearing open of the rift zone in east Puna. The sinking was accompanied by short period harmonic tremor of very small 
amplitude, recorded on a short period horizontal component Sprengnether seismograph on the northeast rim of the caldera. The tremor was shorter in period, but otherwise resembled that known to accompany movement of magma in the volcanic conduits near the surface, and it is believed to have been caused by movement of magma at moderate depth (perhaps 5 kilometers) from beneath the caldera into the opening east rift zone.

Tilting of the ground surface at the northeast edge of the caldera is shown on plate 4 and also in the lower part of figure 33. In the latter graph, the tilt curve represents only the volcanic component of the movement, derived by substracting the normal seasonal tilt as represented by the average tilt during about 20 years of volcanic quiet (dashed curves on plate 4) from the tilting actually measured during 1955. The correlation of tilting with earthquake activity and volcanic tremor is shown in figure 42 and further discussed on a later page.

At first subsidence in the caldera region was not accompanied by any increase of earthquakes in the area, although the amplitude of the harmonic tremor increased steadily. By March 12, however, the deformation appears to have reached a point where it started to produce abrupt displacements between adjacent rock masses and resultant local earthquakes of shallow origin. The earthquake swarm reached major proportions on March 15, culminated with 466 quakes on March 18 , and then slowly declined. A sharp revival of earthquake activity on March 25 sent the number of quakes in the caldera region to almost 1,100 on that day, and almost 1,300 on March 26. Again, most of the earthquake foci were shallow, but some extended to depths as great as $\mathbf{4 5}$ kilometers.

Subsidence of the caldera region continued through March and the first half of April, although the rate of subsidence decreased on March 23 and again on April 10. On April 13 the direction of tilting reversed, and for a few days there appeared to be a slight rise of the caldera floor. It will be noted that this reversal occurred during the period of quiescence in the eruption area. On April 23, 1 day before the resumption of eruptive activity in east Puna, slow subsidence of the caldera floor resumed and continued through the remainder of the year.

Tilting of the ground surface at both the northeast and west rims of the caldera indicated a point of maximum subsidence on the caldera floor 4,700 feet $\mathrm{N}$. $77^{\circ} \mathrm{E}$. of the center of Halemaumau, at approximately the same place as that during the subsidence of December 1950 (Finch and Macdonald, 1953, p. 86). During the period from March 7 to May 26, the ground surface at the Whitney Laboratory tilted 
south-southwestward through an angle of approximately 35 seconds of arc. Assuming the hinge line of the tilting to be at the measuring stations, the amount of sinking just northeast of Halemaumau between March 7 and the end of the eruption on May 26 was about 1.4 feet. Because the tilting must have extended an unknown distance (possibly several miles) beyond the stations, the actual maximum sinking must have been somewhat more than 1.4 feet.

It will be recalled that a rapid subsidence of the summit of Kilauea accompanied and followed the great swarm of earthquakes and opening of the rift zone in east Puna in 1924. The amount and extent of sinking at that time was determined by differential leveling before and after the event (Wilson, 1935, p. 31-55). The amount of sinking in 1955 was much less than that in 1924. If, however, we assume it to have extended over the same area, but with the amount of sinking proportionately less than in 1924, we can calculate the volume of the sinking in the summit region in 1955 .

Using the contours of change during the 1924 subsidence, determined by Wilson (1935, fig. 8), the volume of sinking in 1924 was approximately 1 billion cubic yards. Taking the maximum sinking in 1955 as approximately 0.2 times that at the same place in 1924, and assuming that the sinking was proportionate throughout the area of 1924 subsidence, the volume of sinking during 1955 was approximately 200 million cubic yards. The volume of lava extruded in east Puna was approximately 141 million cubic yards (table 1), and if this is taken to be 20 percent pore space (vesicles and spaces between fragments of cinder and clinker) the volume of lava in completely dense state would be approximately 113 million cubic yards. This is a little more than half the calculated volume of the subsidence in the summit region. However, considering the amount of assumption involved in the calculation of the volume of summit subsidence, the similarity in the two volumes is surprisingly close. Furthermore, obviously not all of the lava involved in the eruption was extruded. An unknown, but probably large, amount of it remained below the surface in the distended rift zone. A dike with a length of 7.5 miles (the combined lengths of the northeast and southwest fissure zones), an average thickness of 1.5 feet; and extending to a depth of 10 miles, would contain a volume of lava approximately equal to the difference in volume (100 million cubic yards) between the extruded lava and the sinking in the caldera region.

Sinking in the caldera area might have been the direct result of drainage from under that area of the lava erupted in east Puna. However, the composition of the lava indicates that that probably was not the case. It has been pointed out on an earlier page that the lavas 
erupted in 1955 are notably more silicic than the average of Kilauea lavas. Such silicic lavas would, if derived by gravitative differentiation from the more ordinary basalts, be expected to occupy the upper part of the magma column. Presumably, the lava erupted in the caldera in 1954 came from the top of the magma column beneath the caldera, but that lava was basalt distinctly poorer in silica than the 1955 lavas. The period of 8 months between the two eruptions would appear to be wholly inadequate for the formation of a large volume of more silicic magma from magma such as that erupted in 1954. It must be concluded, therefore, that the magma that moved from beneath the caldera in 1955 merely took the place of that which was erupted in east Puna, but did not itself reach the surface. The evidence seems to indicate the existence of reservoir complexes of partly fluid magma, capable of distension and contraction and of permitting gravitative differentiation, at a depth of a few (perhaps 3 to 5 ) kilometers beneath both the caldera region and the rift zone.

\section{LeVDLING AT KTHAUEA CATDERA}

During September 1955, a line of differential levels was run from the Volcano House bench mark on the northeast rim of Kilauea caldera, around the north and west rims of the caldera past the Volcano Observatory, and across the caldera floor to the southeast rim of Halemaumau crater. The equipment used was a Coast and Geodetic Survey type precise level and an invar rod. Work was done only on calm days, in fair weather, but no special precautions were taken to shade the level, and no temperature corrections were made. Owing to lack of time, the loop was not closed; but the line was double rodded, all sights were short and approximately balanced, and great care was taken in reading the rod. The two rod lines closed on the bench mark at Halemaumau with a difference of only 1 millimeter, and at no place on the route did the height of instrument determined from the two rod lines differ by more than 2 millimeters. The total number of instrument setups was 114, in a length of line of 5.25 miles. The locations of the bench marks are shown in figure 46.

The elevation of the Volcano House bench mark was taken to be the same $(3,972.541$ feet) as that determined by Wilson $(1935$, p. 46$)$ by first order leveling from tide level at Hilo in 1926. Table 4 gives the elevations of the other bench marks as determined by their differences from the Volcano House bench mark. In addition to the Volcano House bench mark, two other bench marks used by Wilson were reoccupied. The table gives their elevations as determined by Wilson $(1935$, p. 51) in 1927 , and the differences of the elevations in 1955 from 
those in 1927. The bench mark at the Uwekahuna triangulation station and that at the southeast rim of Halemaumau are no longer the same ones used by Wilson.

The bench mark on the "Sand Spit," on the caldera floor southeast of Halemaumau, appears to be approximately 1.2 feet lower in relation to the Volcano House bench mark than it was in 1927; and that at the rift-zone cracks southwest of Halemaumau, outside the caldera proper, appears to be approximately 0.5 foot lower. A bench mark on the southeast rim of Halemaumau at a site close to that of bench mark 10, in 1931 had an elevation of 3,644 feet, approximately 3.6 feet higher than the present bench mark. Thus there appears to have been a down-bowing of the caldera floor, greater at Halemaumau than near its edges, in relation to the northeast rim of the caldera. This lowering appears to have dropped the caldera floor to a level lower than that at which it stood only 3 years after the great collapse of 1924 . Probably the gross movement of the caldera floor over any reasonably long period during the active life of the volcano is always downward, except when its level is raised by flooding with new lava.

TABLE.4.-Elevations of bench marks at Kilauea caldera

\begin{tabular}{|c|c|c|c|c|c|}
\hline \multicolumn{3}{|r|}{ Benchmark } & \multirow{2}{*}{$\begin{array}{l}\text { Elevation } \\
\text { in 1927 } \\
\text { (feet) } \\
\text { (Wilson, } \\
\text { 1935) }\end{array}$} & \multirow{2}{*}{$\begin{array}{l}\text { Elevation } \\
\text { in } 1955 \\
\text { (feet) }\end{array}$} & \multirow{2}{*}{$\begin{array}{l}\text { Difference } \\
\text { of } 1955 \\
\text { elevation } \\
\text { from that } \\
\text { of } 1927 \\
\text { (feet) }\end{array}$} \\
\hline$\underset{\text { ber }}{\text { Num- }}$ & Name & Description & & & \\
\hline- & Volcano House .....- & $\begin{array}{l}\text { Bronze tablet in top of concrete col- } \\
\text { umn, south. of highway, } 250 \text { feet } \\
\text { north west of Volcano House. }\end{array}$ & $3,972.541$ & $3,972.541$ & \\
\hline 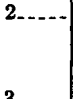 & $\begin{array}{l}\text { Bird Park Inter- } \\
\text { section. }\end{array}$ & $\begin{array}{l}\text { Bronze tablet in masonry at end of } \\
\text { culvertbeneath highway near south- } \\
\text { east corner of intersection of highway } \\
\text { and road to Bird Park. }\end{array}$ & & $4,000.58$ & \\
\hline$\ldots$ & Uwekahuna........ & $\begin{array}{l}\text { Bronze tablet at Uwekahuna triangu- } \\
\text { lation station. }\end{array}$ & - & $4,087.56$ & \\
\hline & $\begin{array}{l}\text { Volcano Observa- } \\
\text { tory. }\end{array}$ & $\begin{array}{l}\text { Bronze tablet in masonry bench at } \\
\text { crater overlook outside building of } \\
\text { Hawailan Volcano Observatory on } \\
\text { Uwekahuna bluff. }\end{array}$ & & $4,076.26$ & \\
\hline 5 & Southwest rift... & $\begin{array}{l}\text { Cross chiseled in stone in top of } \\
\text { masonry at end of culvert on west } \\
\text { side of crater road, } 1.4 \text { miles } \mathrm{S} .15^{\circ} \mathrm{W} \text {. } \\
\text { of Volcano Observatory. }\end{array}$ & & $3,778.23$ & \\
\hline $7 \ldots \ldots$ & Magnetometer 11 & $\begin{array}{l}\text { Bronze tablet in top of large boulder } \\
\text { standing about } 18 \text {. inches above } \\
\text { ground, alongside the largest crack } \\
0.75 \text { mile } \mathrm{S} .60^{\circ} \mathrm{W} \text {. of Halemaumau. } \\
\text { Top of north concrete hub at magne- } \\
\text { tometer station } 11 \text {. }\end{array}$ & $3,724.232$ & $3,751: 12$ & -0.47 \\
\hline $8 \ldots$ & Spit..... & $\begin{array}{l}\text { Bronze tablet in top of large boulder } \\
\text { about } 300 \text { feet east of west end of the } \\
\text { ash-covered spur extending west- } \\
\text { ward into the caldera, } 500 \text { feet south } \\
\text { of south side of Halemaumau park- } \\
\text { ing area. }\end{array}$ & $3,647.139$ & $3,645.97$ & -1.17 \\
\hline $9 \ldots$ & Southeast tilt cellar. & $\begin{array}{l}\text { Bronze tablet at northwest corner of } \\
\text { tilt cellar building near southeast } \\
\text { rim of Halemaumau. }\end{array}$ & & $3,639.45$ & \\
\hline $10 \ldots$ & Pit southeast & $\begin{array}{l}\text { Bronze tablet in top of concrete post } \\
\text { set fush with ground at southeast } \\
\text { rim of Halemaumau. }\end{array}$ & & $3,640.40$ & \\
\hline
\end{tabular}




\section{CHRONOLOGICAL SUMMARY}

The 1955 eruption of Kilauea was attended by two remarkable series of earthquakes. One series, which began more than a year before the outbreak of the eruption, originated in and near Kilauea caldera in response to the movement of magma beneath the summit of the volcano. This series culminated in a swarm of earthquakes accompanying the rapid subsidence of the caldera region soon after the beginning of the eruption in Puna. The other series originated along the east rift zone, where the volcano poured out the lavas of the 1955 eruption. These earthquakes appear to have been closely related to the actual splitting open of the fissures that fed the eruption. Both series were characterized by a large number of very small earthquakes punctuated at intervals by earthquakes of moderate size.

In addition to these two series of earthquakes, other larger shocks occurred in Kilauea before, during, and after the eruption.

Harmonic tremor of two distinct origins was recorded during the eruption. Whila lava was actually pouring out through the east rift zone, harmonic tremor of rather long period, 0.8 to $1.0 \mathrm{sec}$., was recorded on the Loucks-Omori seismograph at Pahoa and on the more sensitive seismographs at Kilauea caldera. The rapid subsidence of the caldera was accompanied by weak harmonic tremor, with a period of 0.3 to 0.5 sec., recorded on a modified short-period horizontalcomponent Sprengnether seismograph on the east rim of the caldera. This tremor closely resembled that accompanying eruptions in Kilauea caldera.

The 1955 eruption was the culmination of a sequence of events at Kilauea that began early in 1950. A unifying thread linking these events and putting the earthquakes that preceded the 1955 eruption in proper perspective was the tilting of the earth's surface at the Whitney Laboratory of Seismology on the northeast rim of the caldera. In figure 35 the tilt anomaly at this station, obtained by subtracting the average tilt over a period of years from the current tilt, is plotted and correlated with eruptions and major seismic events from 1950 through 1955. An accumulation of northeastward tilt indicates swelling of the summit of the volcano, and sharp southwestward tilt indicates a rapid subsidence of this region. In general, the north-south component of tilt at the Whitney Laboratory reflects swelling and shrinking of the summit of the volcano with somewhat higher fidelity than does the east-west component.

Following its 1934 eruption, Kilauea waited for 18 years, until 1952, to erupt again. Signs of growing instability preceded the 1952 revival 


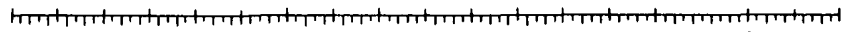

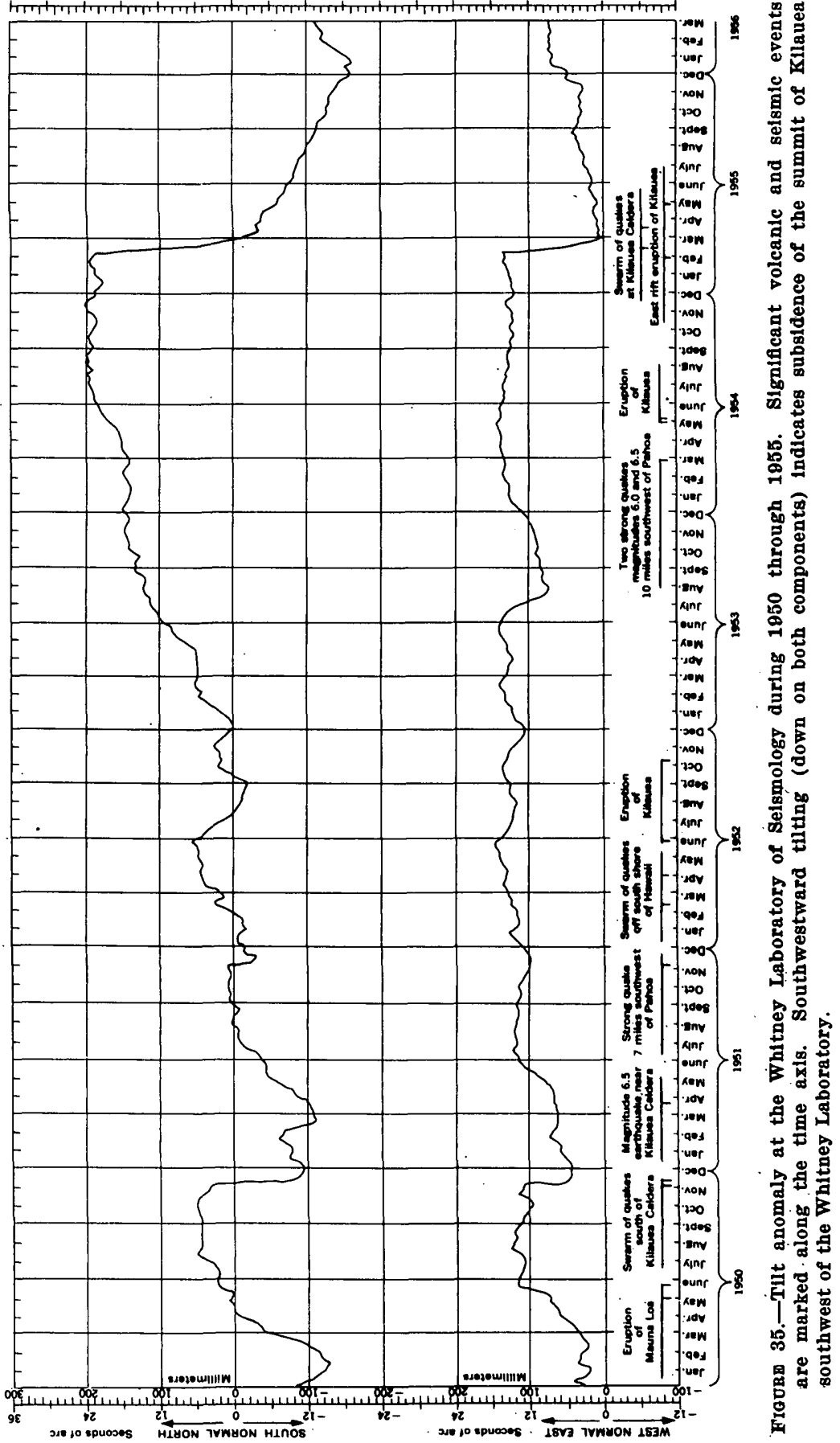


by more than 2 years, however. Swelling at the summit of the volcano that began early in 1950 was terminated in December of that year, when the summit subsided rapidly during a swarm of shallow earthquakes that originated just south of the caldera.

Within a few months the volcano began to swell again, and the swelling continued with only minor interruptions until the beginning of the 1952 eruption. As the lavas of the 1952 eruption poured out into Halemaumau, the summit of the volcano subsided slowly. By early October, 1952, more than a month before the eruption ended, subsidence stopped, and the volcano began to swell again.

Few earthquakes occurred during the early part of 1953 , but at the end of April, when the excess northeastward tilting at the Whitney Laboratory was approaching the value it had just before the outbreak of the 1952 eruption, several moderate earthquakes originated beneath the upper portion of Kilauea's southwest rift zone. A feeble resurgence of seismic activity at Kilauea initiated by these earthquakes died out during the next few months.

Seismic activity revived sharply during the last week in October with a short sequence of moderate to strong earthquakes along the Chain of Craters on the upper part of Kilauea's east rift zone. As the yearlong episode of gradual tumescence ceased in mid-November, a series of frequent small earthquakes began at Kilauea caldera. This series reached a maximum by the end of the month and died out slowly during December. Most of the first quarter of 1954 was quiet seismically, and no further tumescence occurred in this interval.

On the morning of March 30, 1954, two severe earthquakes originated several miles south of the east rift zone near the coastal village of Kalapana. These earthquakes and their aftershocks, which appear to have been of moderately shallow origin (perhaps $5 \mathrm{~km}$ deep), did not occur on the east rift zone proper, but on one of the east-west-trending normal faults in the vicinity of Kalapana. Almost immediately, the series of earthquakes at Kilauea caldera revived and the summit of the volcano began to swell again. As before, earthquakes of the summit series were characteristically small and of shallow origin, although a few were large enough to be felt locally and some originated at moderate depths. From March 30 through May 31 almost 1,000 earthquakes occurred in or near Kilauea caldera and tumescence of the area continued at a steady rate.

Early on May 31, 1954, a short-lived eruption broke out in Kilauea caldera. This eruption, which lasted only 4 days, did not interrupt the series of earthquakes nor the steady swelling at the summit that recommended at the time of the severe Puna earthquakes. 
From June 18 through June 21 a great swarm of tiny earthquakes accompanied by many hours of spasmodic tremor originated about 40 $\mathrm{km}$ beneath Kilauea caldera. Several of the largest of these earthquakes were felt at scattered points around the island of Hawaii. Like the eruption 3 weeks earlier, these earthquakes had no effect on the series of shallow earthquakes at Kilauea caldera nor on the gradual tumescence of the volcano.

By the time tumescence ceased about the middle of August 1954, the summit of Kilauea had swollen to the greatest height it had attained since the great summit collapse and steam blast eruptions of 1924 . This high level was maintained and the series of earthquakes at the caldera continued at a moderate rate until the beginning of the rapid subsidence of the caldera region in March 1955, shortly after the outbreak of the Puna eruption.

Following a short sequence of aftershocks, the only seismic activity that persisted in Puna after the earthquakes of March 30, 1954, issued from the east rift zone a few miles southeast of Pahoa. From this region tiny, sharp, shallow earthquakes at an average rate of about 25 per month continued through the spring, summer, and early fall of 1954.

On September 1, 1954, a small swarm of 22 earthquakes emanated from the east rift zone near Pahoa. This swarm was followed, on September 12 and 13, by a siege of small earthquakes and spasmodic tremor from deep within Kilauea beneath the summit area. Again, on November 23 and November 26 small swarms of earthquakes from the east rift zone near Pahoa were recorded. These swarms, too, were followed, on December 3, 4, and 5, by another episode of small earthquakes and spasmodic tremor from deep within the volcano.

Late in 1954 the number of earthquakes stemming from the east rift zone near Pahoa began to increase. A total of 67 occurred in November; 81 , in December; 185, in January 1955; and 350, between February 1 and February 23, 1955. On February 23, an earthquake of moderate size occurred at a depth of about $25 \mathrm{~km}$ under the east rift zone of Kilauea near Makaopuhi Crater. After this date the number of earthquakes stemming from the east rift zone southeast of Pahoa rose sharply. Only 13 earthquakes from this region were recorded on February 23. This number increased rapidly to 130 on the 24 th, 350 on the 25 th, 600 on the 26 th, and 700 on the 27 th. Early on February 28 the frequency of earthquakes dropped off sharply; and at $7^{\mathrm{h}} 45^{\mathrm{m}}$ the first harmonic tremor, heralding the beginning of a rapid flow of lava up through feeding channels, appeared on the Pahoa seismogram as the 1955 eruption broke through to the surface. 
While the eruption was in progress and lava was pouring out freely at the surface, very few earthquakes were recorded. Earthquakes resumed immediately after the cessation of activity at the Puu Honuaula vents (pl. 1, vents $\mathrm{A}-\mathrm{C}$ ). The frequency of earthquakes diminished slowly after the outbreak at vent E (pl. 1) on March 2 and as the opening of new vents came to an end on March 3 . While the most spectacular lava fountaining of the whole eruption was in progress at vent $\mathbf{E}$ on March 4, virtually no earthquakes were recorded, although long-period harmonic tremor of moderate amplitude was recorded both at Pahoa and at Kilauea caldera.

By noon on March 5 the fountain at vent $\mathrm{E}$ was greatly reduced in size, and earthquakes in the eruption area had almost ceased. At about $12^{\mathrm{h}} 30^{\mathrm{m}}$ a spectacular swarm of earthquakes began at a source near Kalalua Crater, on the east rift zone of Kilauea 9 miles west of the Pahoa-Kalapana road. For several hours seismographs on Hawaii were in constant motion. This swarm lasted for about 24 hours during which time the earthquakes diminished in frequency and intensity. These earthquakes appear to have originated at a very shallow depth.

On March 7 the Kilauea summit region began to respond to changes of the previous week in east Puna. This response probably was made possible by splitting open of the east rift zone near Kalalua Crater 2 days earlier. Although no increase in seismic activity at Kilauea caldera began until March 12, on March 7 the top of the volcano began to subside rapidly. At the same time, minute short-period harmonic tremor closely resembling tremor from eruptions at Kilauex caldera began to record on a sensitive seismograph on the east rim of the caldera.

Several strong earthquakes originated south of the east rift zone, near Kalapana, and the number of earthquakes from the east rift zone itself began to increase rapidly on March 7. The renewed swarm, which centered south of Pahoa rather than near the early vents southeast of Pahoa, intensified on March 8 and reached a maximum on March 9, when almost 1,400 earthquakes were recorded at Pahoa. On subsequent days the frequency of earthquakes diminished gradually.

From March 7 to March 12, continuous harmonic tremor emanated from beneath the Kilauea summit, which was subsiding rapidly, and countless earthquakes stemmed from the east rift zone 25 miles east of the summit, but no lava appeared at the surface. Following the renewed outbreak of lava south of Pahoa on March 12, seismic activity in Puna continued at moderate intensity as long as new sections of the rift were being split open and new vents formed. After the last 
new section of the rift opened on March 26, seismic activity in Puna dropped to a low level for the rest of the eruption.

The long series of small earthquakes at the summit of Kilauea that preceded the eruption began to intensify on March 12, and on March 15 it built up to a swarm of major proportions. This swarm reached a first maximum on March 18 and then declined slowly. Earthquakes of this group were mostly small and shallow, and they appear to have originated within a few. kilometers of the Uwekahuna station.

A sharp revival of earthquakes at the caldera on March 25 sent the number for the day to almost 1,100. Although the average size of . the earthquakes diminished, an even greater number, almost 1,300, was recorded on March 26. From March 25 to March 28 the focal zone of these earthquakes extended to depths as great as $45 \mathrm{~km}$, reaching the region from which several swarms of small earthquakes and spasmodic tremor had originated prior to the 1955 eruption.

On the afternoon of March 27 a moderate, shallow earthquake, which originated near the east rim of the caldera, opened a crack across the highway east of Hawaii National Park headquarters and broke waterlines in the Park housing area. This earthquake was much smaller than many others that accompanied the eruption, but its very shallow focus beneath a populated area gave it a local importance incommensurate with its magnitude.

The subsidence of the caldera, which began on March 7, continued until the end of the swarm of earthquakes in the summit region in mid-April, although the rate of subsidence decreased on March 23 and again on April 10. After a weak reversal of tilt between April 13 and April 22, slow subsidence of the caldera started once more and continued until the end of the year.

\section{EARTHQUAKES OF THE KTLAUFA SUMMIT SFRIES}

Except for number, earthquakes from the summit area that preceded and followed the eruption were very similar to those of the major swarm that accompanied subsidence of the caldera region in March and April, 1955. Only the less frequent larger earthquakes of this swarm were clearly recorded by a sufficient number of seismographs to permit reasonably accurate focal point determinations. Most were so small and shallow that they were recorded only by the sensitive seismographs around the caldera.

Epicenters of the larger quakes were scattered more or less at random over an area about $20 \mathrm{~km}$ across and centered at the south rim of Kilauea caldera. Some concentration of epicenters occurred on prominent structures such as the caldera, Chain of Craters, and Kaoiki and Hilina fault systems. Focal depths ranged from near-surface to about 
$30 \mathrm{~km}$, except for the very deep swarm of quakes and tremor that originated about $45 \mathrm{~km}$ beneath the caldera.

Seismograms from deep (Aug. 14, 1955) and shallow (Mar. 27, 1955 ) earthquakes from the summit region are reproduced in figure 36 to illustrate how critically focal depth influenced the appearance of the seismographic record of these earthquakes.

During the major swarm in late March, $S-P$ intervals at Uwekahuna, for quakes where $P$ could be resolved, ranged from $1 / 2$ to 2 seconds with an interval of 1 second being by far the most common. A small portion of the seismograms recorded by a standard short-period Wood-Anderson seismograph on the east rim of the caldera during the most intense part of the summit swarm is reproduced in figure 37 .

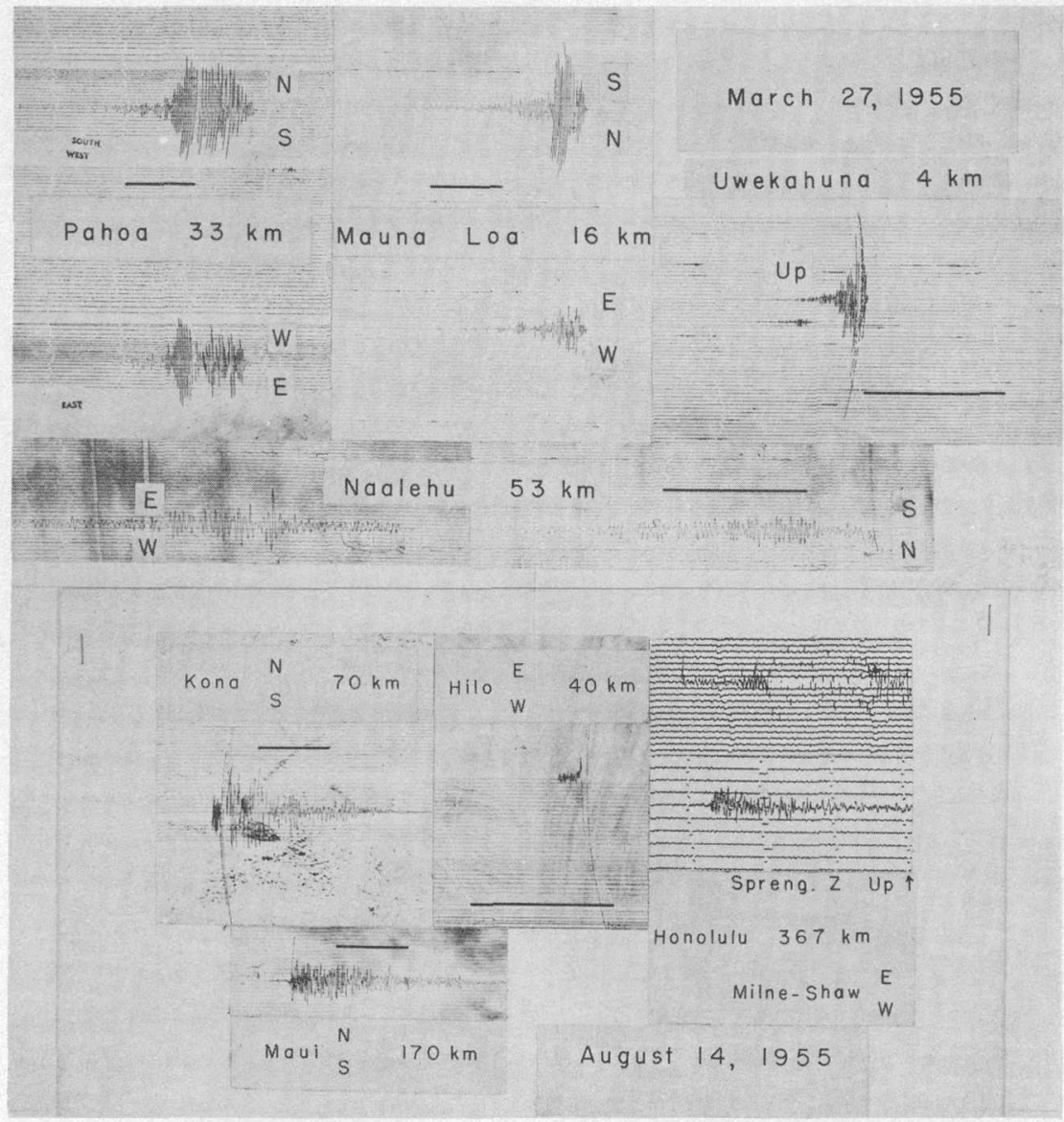

Figure 36.- Seismograms from Hawailan stations for the shallow focus $( \pm 5 \mathrm{~km})$ earthquake of March 27, 1955, and the deep focus (about $30 \mathrm{~km}$ ) earthquake of August 14, 1955. Time advances to the left on records of the March 27 quake and to the right on records of the August 14 quake. Minute lengths are indicated by the heavy lines. 
Most of these earthquakes occurred at very shallow depths beneath or very near the caldera.

\section{EARTHQUAKES OF THE EAST RIFT ZONE SFRIHS}

From March 30, 1954, through February 23, 1955, an increasing number of earthquakes occurred along parts of the east rift zone later split by eruptive fissures. These earthquakes were mostly so small that they were recorded only at Pahoa. Beginning in January 1955 occasional earthquakes originated just east of the bend in the east rift zone, in the vicinity of Kalalua Crater. All these earthquakes were very shallow in origin, yet seismograms of the earthquakes near Pahoa contrasted sharply with those of the earthquakes near Kalalua Crater. These differences will be discussed later in connection with earthquakes from the same two regions during the eruption.

Because they were too small to be recorded adequately at more distant stations, earthquakes from the east rift zone eruption area must be located solely on the basis of the Pahoa seismograms. In addition to the unequivocal $S-P$ interval recorded at Pahoa for almost all these earthquakes, clear evidence on the direction of first motion in the $P$ and $S$ wave groups is available for many. From these data, we can calculate an approximate distance and azimuth from Pahoa to the source of the earthquakes and we can set limits on the faulting capable of producing the observed first-motion patterns.

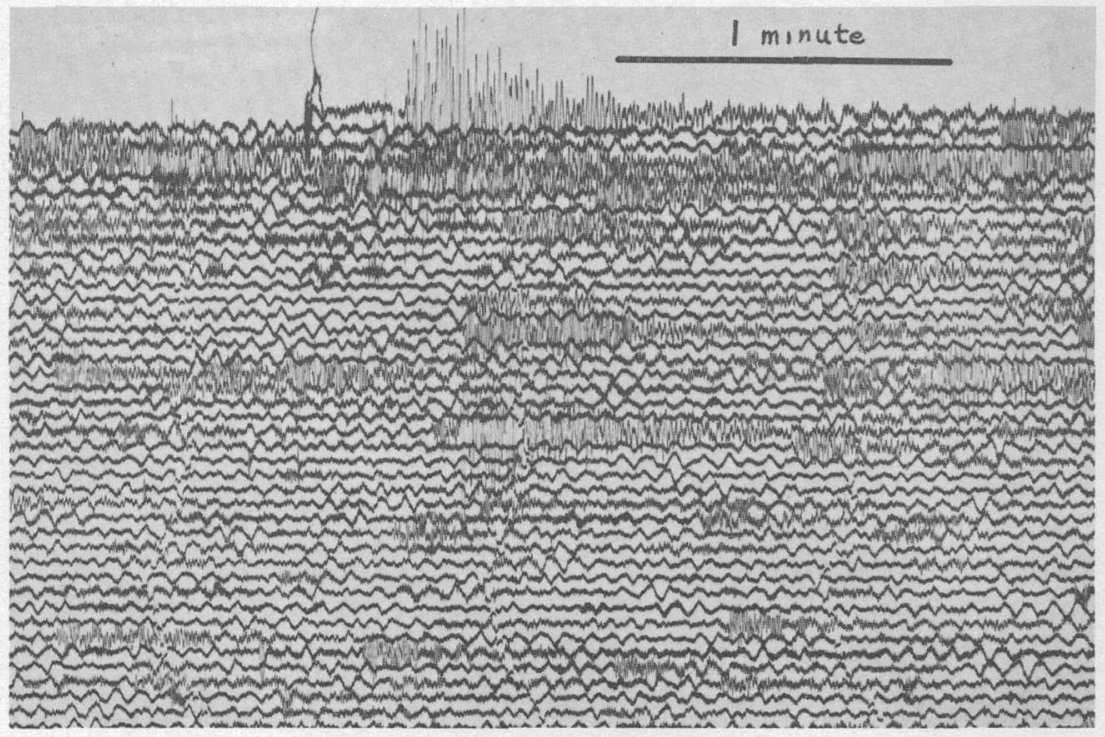

Frgure 37.-Part of the Kllauea summit earthquake swarm recorded by a standard Wood-Anderson seismograph on the northeast rim of Kilauea caldera on March 25. 
During any short period of time, earthquakes of the east rift zone series produced remarkably similar records on the Pahoa seismograph. From day to day as the eruption progressed, however, systematic changes in $S-P$ interval and in the direction of first motion of $P$ and $S$ occurred. On the basis of such systematic changes in the records of its earthquakes, the eruption swarm can be divided into a number of epochs. In most instances earthquakes of a given epoch can be logically correlated with eruptive activity that accompanied or immediately followed them.

In table 5, the most prevalent $S-P$ interval and direction of first motion of $P$ and $S$ at Pahoa are given for the epochs into which the eruption swarm can be divided. The distance from Pahoa to the source of the earthquakes (computed from $S-P$ ), the most probable source of the earthquakes (from field evidence), and the distance and direction of Pahoa from the most probable source are also given in this table. Recalling that the direction of first motion of $P$ at Pahoa should be the same as the direction from the source of the earthquake to Pahoa, since all of the $P$ 's began as compressions, we see from table 5 that earthquakes of the eruption swarm originated in areas where fissures were splitting toward the surface immediately before or during the early stages of a new outbreak. Furthermore, the close correspondence between the distance to Pahoa measured from the suspected epicentral region (along the surface) and calculated from the $S-P$ interval (along the ray) precludes a depth of focus even as large as the epicentral distance. Thus, focal depths must have ranged from zero to no more than a few kilometers.

The en echelon pattern of eruptive fissures from vents $\mathbf{A}$ to $\mathbf{P}$ (pl. 1) suggests a component of right-lateral offset along a fault beneath these fissures, whereas the en echelon pattern of fissures from vents $Q$ to $U$ suggests left-lateral offset along an underlying fault.

TABLE 5.-Epochs of the eruption area earthquake swarm and correspondence between seismic data and field evidence

\begin{tabular}{|c|c|c|c|c|c|c|c|}
\hline \multirow{3}{*}{ Epoch } & \multicolumn{4}{|c|}{ Paboa selsmograph station } & \multicolumn{3}{|c|}{ Most Hkely source } \\
\hline & \multirow{2}{*}{$\begin{array}{l}S-P \\
(\mathrm{sec})\end{array}$} & \multirow{2}{*}{$\begin{array}{c}\text { Distance } \\
\text { to focus } \\
(\mathrm{km})\end{array}$} & \multicolumn{2}{|c|}{ Direction of first motion } & \multirow{2}{*}{$\begin{array}{l}\text { Vents } \\
\text { (pl.1) }\end{array}$} & \multirow{2}{*}{\begin{tabular}{|c|} 
Distance \\
to Pahoa \\
$(\mathbf{k m})$
\end{tabular}} & \multirow{2}{*}{$\begin{array}{c}\text { Directlon to } \\
\text { Pahoo }\end{array}$} \\
\hline & & & $\boldsymbol{P}$ & $\boldsymbol{s}$ & & & \\
\hline $\begin{array}{l}\text { Feb. 24-28 } \\
\text { Mar. } 1-4 \\
\text { Mar. } 7-11\end{array}$ & $\begin{array}{l}\text { 1. } 2 \\
\text { 1. } 5 \\
1.2\end{array}$ & $\begin{array}{l}\text { 6. } 6 \\
\text { 8. } 2 \\
6.6\end{array}$ & $\begin{array}{l}\text { WNW } \\
\text { SW } \\
\text { NNW to }\end{array}$ & $\begin{array}{l}\text { NE } \\
\text { NW } \\
\text { SW }\end{array}$ & $\begin{array}{l}\text { A-C } \\
M-L \\
Q-U\end{array}$ & $\begin{array}{l}6 \\
8 \\
6\end{array}$ & $\begin{array}{l}\text { WNW } \\
W \\
\text { NW to }\end{array}$ \\
\hline $\begin{array}{l}\text { Mar. 12-15 } \\
\text { Mar. 16-26 }\end{array}$ & $\begin{array}{l}\text { 1. } 2 \\
\text { 1. } 2\end{array}$ & $\begin{array}{l}\text { 6. } 6 \\
6.6\end{array}$ & $\begin{array}{l}\text { NNW } \\
\text { NNE }\end{array}$ & $\begin{array}{l}\text { SW } \\
\text { SSW }\end{array}$ & $\underset{T-U}{Q-R}$ & $\begin{array}{l}6 \\
7\end{array}$ & $\begin{array}{l}\text { NNW } \\
\text { NNE }\end{array}$ \\
\hline
\end{tabular}


Analysis of the directions of first motion of $P$ and $S$ generated by earthquakes along these two major groups of vents argues against the horizontal offsets suggested by the en echelon pattern of fissures. It appears that dip-slip dislocations along two normal faults, one through each of the major groups of vents, both dipping steeply $\left(70^{\circ}\right.$ to $\left.90^{\circ}\right)$ toward the southeast and with the southeast side downthrown, would account for the observed directions of first motion of $P$ and $S$.

During the forenoon of March 5 all evidence from Puna suggested the eruption was nearing its end. The only lava fountain still active was at vent $\mathrm{E}$, and its output of lava had diminished greatly from the previous day. Neither earthquakes nor harmonic tremor of significance were keing recorded by the Pahoa seismograph.

At about $12^{\mathrm{h}} 25^{\mathrm{m}}$ sensitive seismographs at Kilauea caldera began to record a. disturbance that slowly intensified, for about 15 minutes, until the records became entirely illegible. For the next 2 hours the disturbance continued at such intensity that these records remained illegible. After 6 hours, small and moderate earthquakes still were following one another so closely that their records overlapped.

The insensitive Loucks-Omori seismographs in use at most Hawaiian stations were much less disturbed by the continuous ground motion during the height of the disturbance, and they recorded a number of large earthquakes that occurred while the seismograms from the more sensitive instruments were unreadable. These earthquakes, the largest at $12^{\mathrm{h}} 58^{\mathrm{m}}$, originated at very shallow depths along the upper end of Kilauea's east rift zone near Kalalua Crater. For the next 24 hours a swarm of earthquakes of declining size and frequency of occurrence continued to emanate from the same region.

In most respects the Kalalua and eruption area swarms of earthquakes'were very different. The Kalalua swarm began sharply, included many quite large earthquakes (up to magnitude 5.3), and was of short duration. In contrast, the eruption area swarm began gradually, included no large earthquakes (none larger than magnitude 4.3), and lasted for several weeks. Parts of seismograms of these two swarms are compared in figure 38 ; in figure 39 individual earthquakes from the two swarms, both recorded on the Pahoa seismograph, are presented.

The absence of short-period waves in the record of the Kalalua quakes at Pahoa is characteristic of very shallow Hawaiian earthquakes. Although the eruption-area quakes were also of shallow origin, they originated so near Pahoa that the multilayered Hawaiian crust was less effective in filtering out their short-period waves than it was for the Kalalua quakes. 
An explanation for the overall differences between the two swarms is to be sought in the processes that generated them. The eruption area swarm appears to have been generated by the piecemeal upward splitting of fissures through which lava was rising toward the sur-

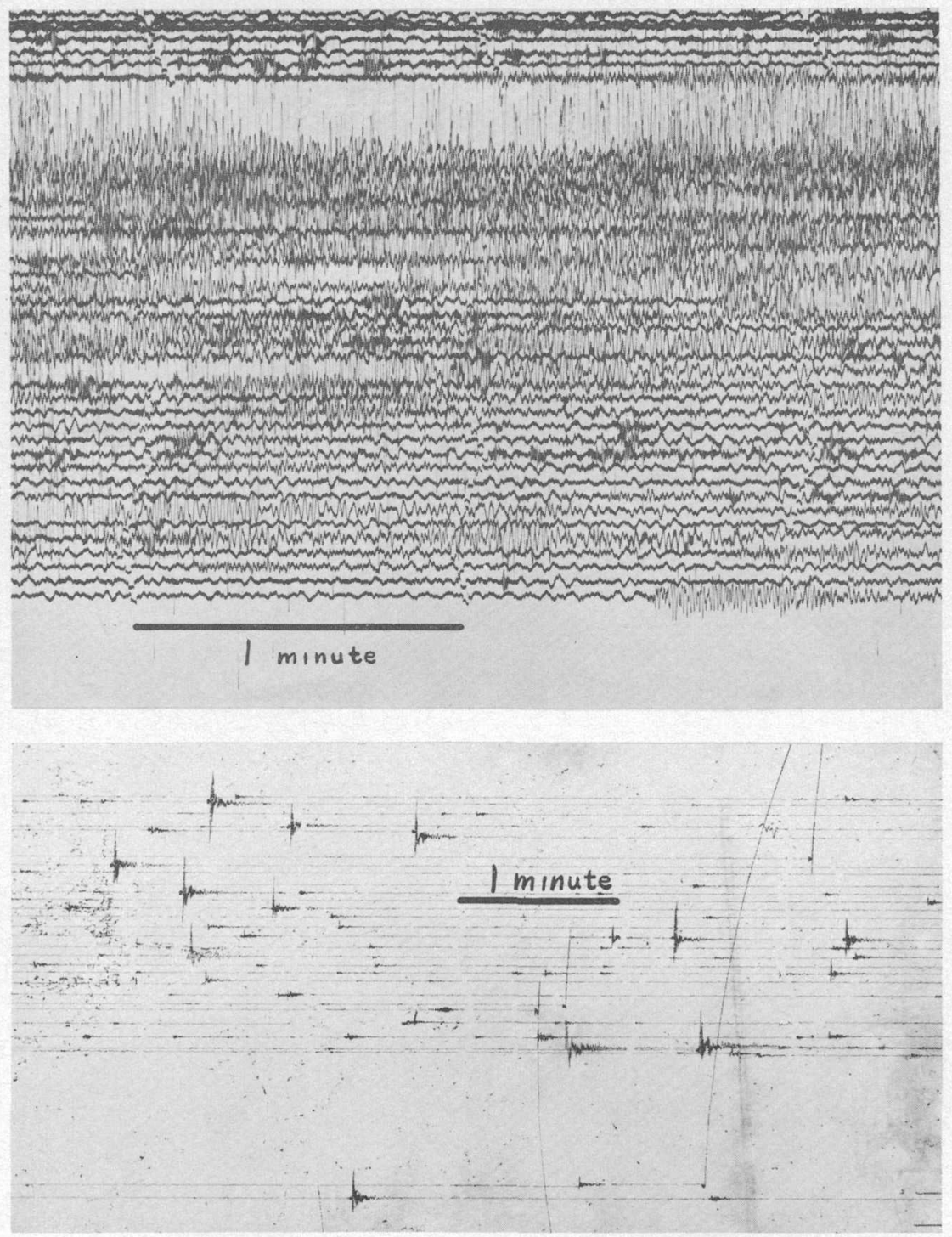

Figdre 38.-Part of the Kalalua earthquake swarm recorded on a standard Wood-Anderson seismograph on the northeast rim of Kilauea caldera on March 5 (upper record), and a part of the eruption area earthquake swarm recorded by the Loucks-Omori seismograph at Pahoa on March 11 (lower record). 
face. Rupture of the rock at any given place temporarily relieved the accumulating stress caused by the incursion of the eruptive dike. The Kalalua swarm, on the other hand, appears to have been caused by a wholesale breakdown of a blockage preventing movement of lava from the storage zone beneath the Kilauea summit into the rift zone core.

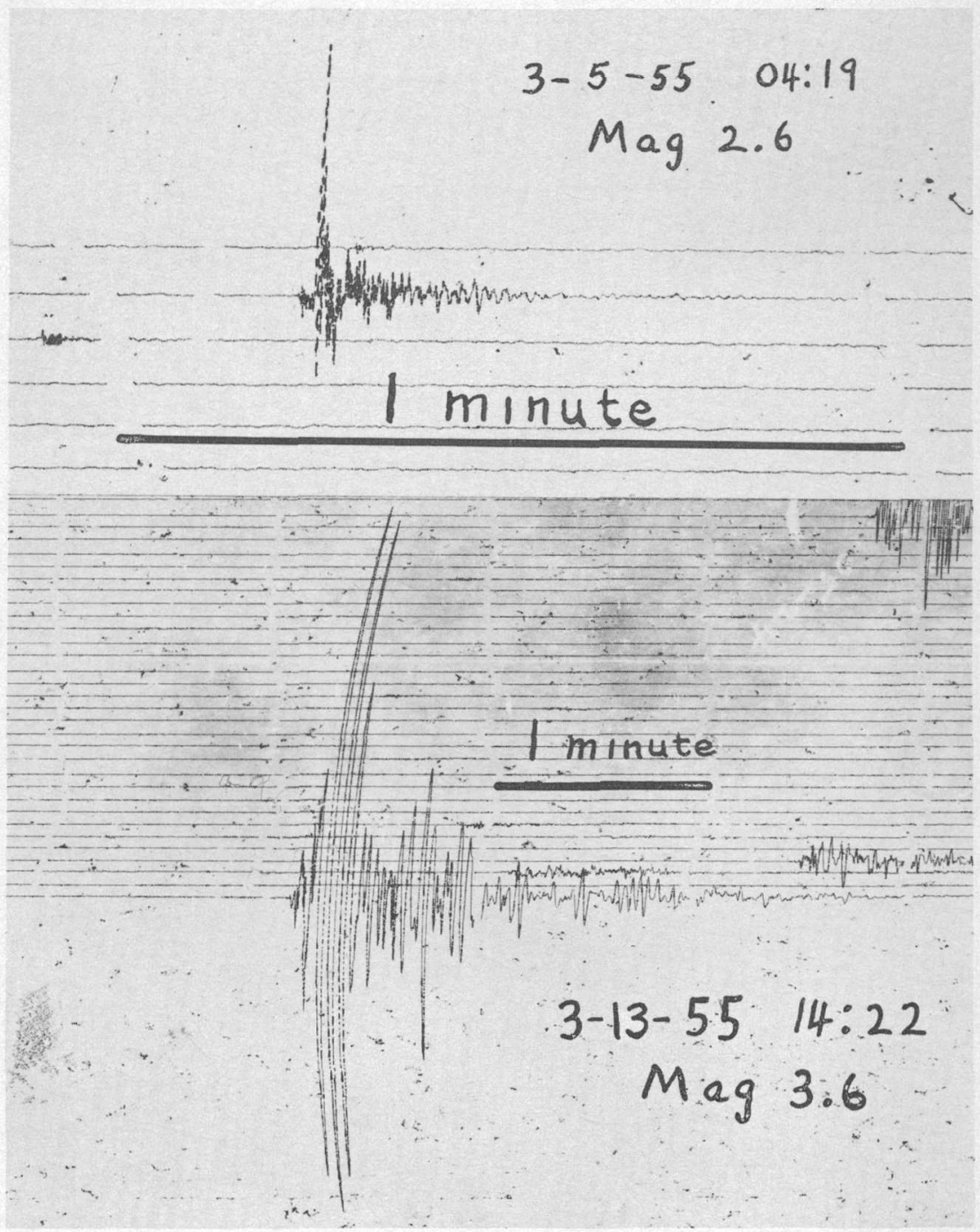

Figdre 39.- - Individual earthquakes from the eruption area swarm (upper) and Kalalua swarm (lower) recorded on the Loucks-Omori seismograph at Pahoa. The upper record has been enlarged nearly 4 times relative to the lower. 


\section{GARMONIC TREMOR}

Harmonic tremor of two distinct origins was recorded during the 1955 eruption of Kilauea. The most prominent tremor, which had a period of 0.8 to 1.0 second, was closely associated with actual eruption of lava from the vents. in Puna. Although it was somewhat more clearly recorded on the sensitive seismographs at Kilauea caldera, 30 to $45 \mathrm{~km}$ from the vents, than on the less sensitive seismograph at Pahoa, only 6 to $10 \mathrm{~km}$ from the vents, the actual ground motion at Pahoa was 3 to 5 times larger than that at the caldera.

The several rapid starts and stops of eruptive activity in Puna provided excellent opportunities for verifying that the long-period tremor was generated at or near the active vents. Moreover, the amplitude of the long-period harmonic tremor correlates well with field estimates of the rate of extrusion of lava.

Figure 40 is a part of the record of a modified short-period-horizontal-component seismograph on the east rim of Kilauea caldera showing long period harmonic tremor produced by the last fountain active in Puna. The sudden disappearance of this tremor at $11^{\mathrm{b}} 14^{\mathrm{m}}$ marks the end of the eruption.

At about $7^{\mathrm{h}}$ on March 7 the most sensitive seismograph operating on Hawaii, a modified short-period horizontal-component Sprengnether seismograph on the east rim of Kilauea caldera, began to record a very small, short-period harmonic disturbance. During the next few days the disturbance grew larger, and it became clear that this was harmonic tremor with a period of about 0.4 second, very similar except for size to the harmonic tremor of much larger amplitude recorded at the Whitney Laboratory during Kilauean summit eruptions. For nearly a week, before the renewal of the eruption in Puna, the short-period tremor steadily increased in size. On March 14 it attained a maximum ground amplitude of about 0.4 micron, which it maintained for about 3 days, and then it died out rapidly on March 18.

Since this tremor was recorded only by sensitive seismographs near the caldera and corresponds in time to the beginning and most rapid subsidence of the summit of Kilauea, it seems likely that it was generated at moderate depth by the withdrawal of magma stored beneath the summit of the volcano.

Part of the seismogram from the modified Sprengnether seismograph, showing the maximum of the short-period tremor, is reproduced in figure 41 .

The strain-release index (Macdonald and Eaton, 1957, p. 32-34) is another step toward an adequate representation of the amount of seismic activity in a given geological unit during a specified time 
interval. This index, originally defined for the short-period vertical Sprengnether seismograph at Uwekahuna, was extended empirically to permit its use with the Loucks-Omori seismographs used in other stations on Hawaii. For a group of earthquakes recorded during October 1954 on the Sprengnether and on a Loucks-Omori temporarily set up beside it, the average ratio of the maximum amplitude on the Sprengnether to that on the Loucks-Omori was 6.5. Using this ratio we can write: $S-R$ index $=\sqrt{(S-P) \mathrm{A}}=\sqrt{(S-P) 6.5 a \text {, }}$ where $S-P$ is the duration in seconds of the preliminary tremor, $A$ is the maximum double amplitude in $\mathrm{mm}$ on the Sprengnether record, and $a$ is the maximum double amplitude in $\mathrm{mm}$ on the Loucks-Omori record.

Two units into which it is convenient to divide Kilauea volcano for a seismometric study of the 1955 eruption are east Puna (Kilauea volcano east of the bend in the east rift zone 2 miles east of Napau Crater) and Kilauea summit (Kilauea volcano minus the east Puna unit defined above).

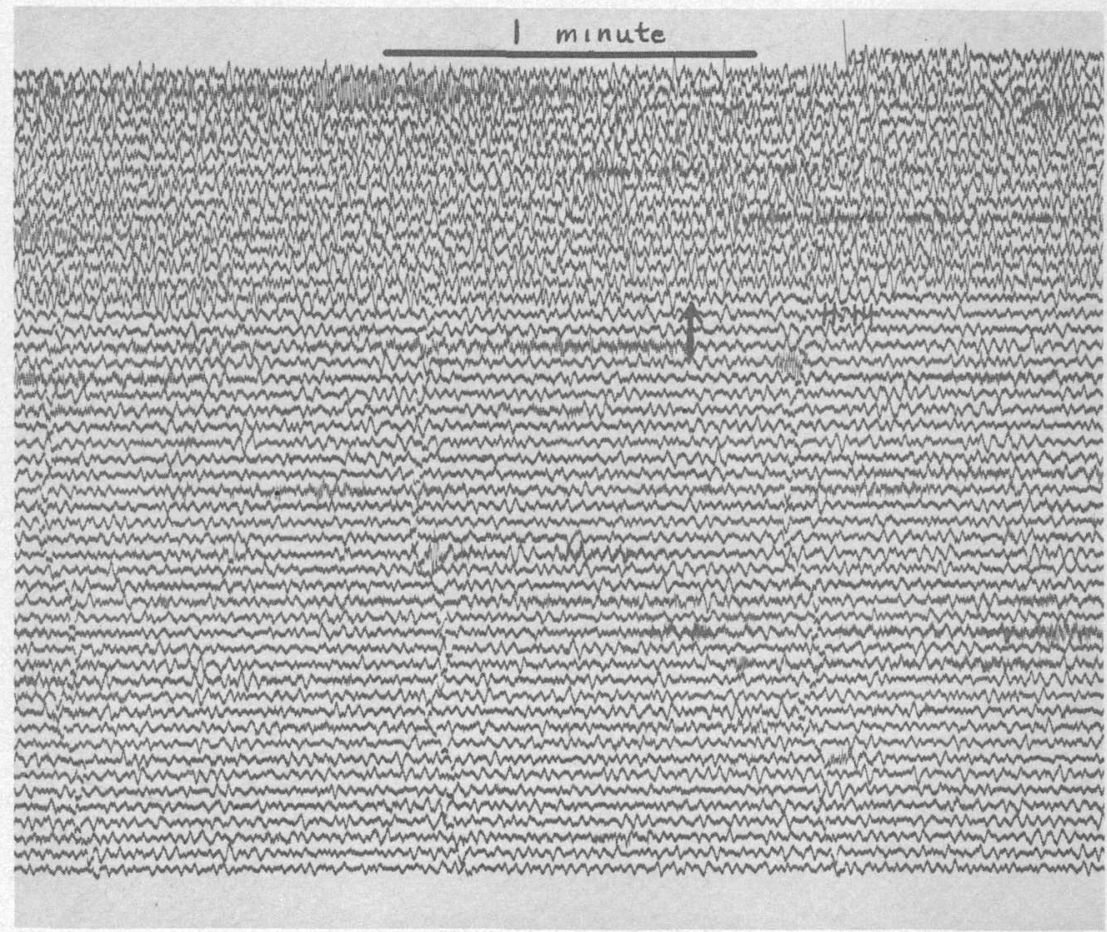

Figure 40.-Harmonic tremor from the eruption area recorded on the modified Sprengnether seismograph on the northeast rim of Kilauea caldera on May 26. The sudden disappearance of the tremor (indicated by the arrow) corresponds to the final cessation of lava extrusion in Puna. 
Because of the great uncertainty in reading and locating very small earthquakes, strain-release indices were tabulated only for earthquakes having an index of $\sqrt{5}$ or larger. Since the significance of earthquakes occurring at abnormally large depths (greater than $25 \mathrm{~km}$ ) under the caldera and its environs is as yet poorly understood and the epicenters of these earthquakes are very difficult to determine, such earthquakes were not included in the computation of strainrelease indices for the Kilauea summit unit.

\section{TREATMENT OF EARTHQUAKE DATA}

Some quantitative statement of the amount of earthquake activity during a given period of time is needed if we are to utilize fully the information on the mechanism of eruption contained in seismic data. Earthquakes differ so greatly in size that the number of earthquakes occurring during a given interval of time is an inadequate measure of seismic activity. In addition to the number, we must consider the size of earthquakes.

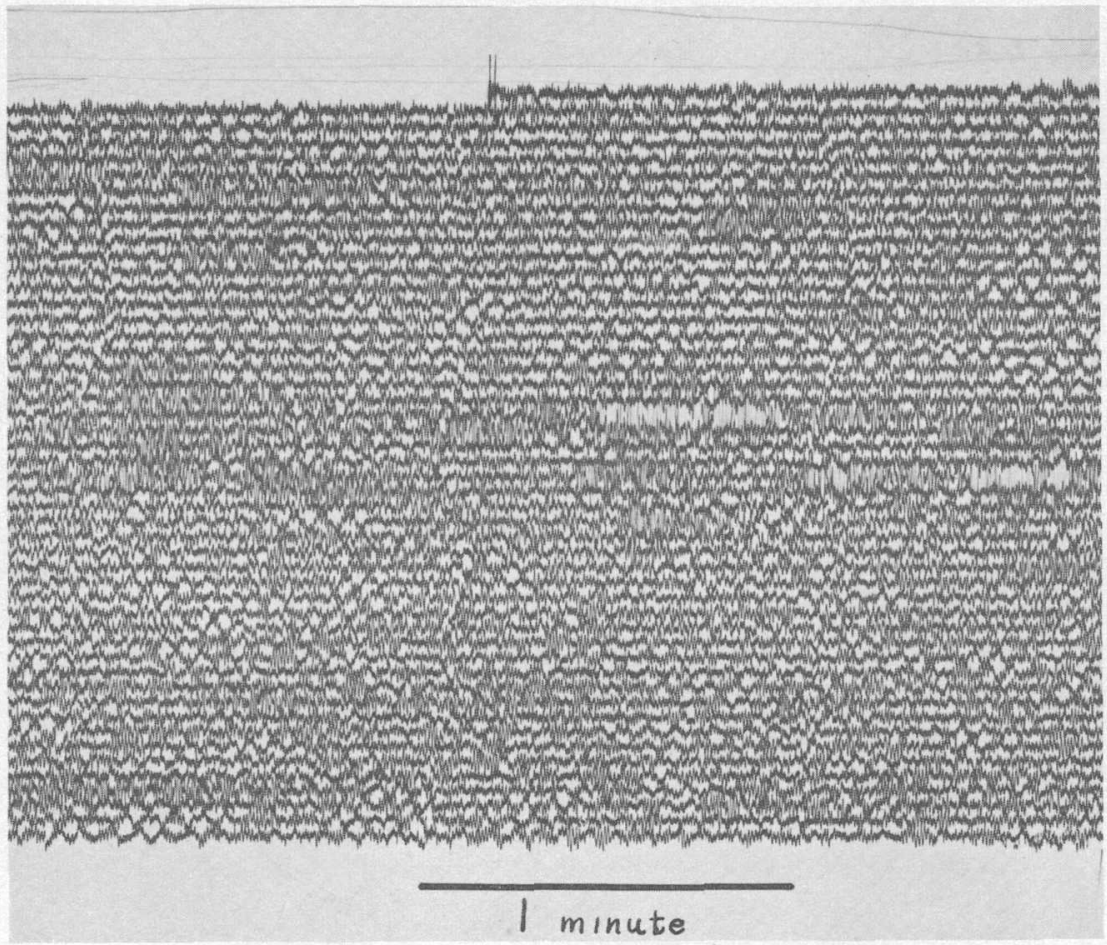

Figure 41.- Short-period harmonic tremor from the summit of Kilauea recorded on the modified Sprengnether seismograph on the northeast rim of Kilauea caldera on March 14. 
Local seismicity (Jones, 1932; Macdonald, 1954b), long in use at the Hawaiian Volcano Observatory, was an attempt to fill this need for a quantitative expression of the amount of earthquake activity in Hawaii. This scale is based on readings of the Bosch-Omori seismograph in the Whitney Laboratory. Only the amplitude on the Bosch-Omori record is considered; no attention is paid to the location of the epicenter or its distance from the Whitney Laboratory.

In recent years a number of new seismograph stations have been built on Hawaii, and more sensitive seismographs have been installed near Kilauea caldera in the Uwekahuna station. Because of these improvements in the seismographs net, reasonably good epicenters can be determined for most local earthquakes. Many earthquakes that are clearly recorded at one of the outstations or at Uwekahuna do not appear on the Bosch-Omori seismograph at the Whitney Laboratory. Moreover, an increase during the last few years in heavytruck traffic over a road very close to the Whitney Laboratory has greatly increased the number of small earthquakelike, artificial disturbances recorded by the Bosch-Omori seismograph. At present identification of earthquakes with a double amplitude less than $1 \mathrm{~mm}$ on this instrument is subject to considerable uncertainty.

On plate 2 weekly strain-release indices and the cumulative strainrelease index, based on the Sprengnether seismograph at Uwekahuna for Kilauea summit during 1953, 1954 and 1955, are presented graphically. The weekly strain-release index for a given unit is the sum of the strain-release indices of the earthquakes occurring during the week in that unit. The cumulative strain-release index is the sum of the weekly indices up to a given time. On plate 3 weekly and cumulative strain-release indices for east Puna during 1954 and 1955, based on the Loucks-Omori seismograph at Pahoa, are presented.

An earthquake's strain-release index is a measure of the amount of fault displacement (or strain release) that produced the earthquake. However, it is biased to favor small earthquakes, by taking the square root of $(S-P) A$, so the swarms of small quakes that appear to herald approaching eruptions are given relatively heavier weight than the very large earthquakes whose connection with eruptions is more obscure. The slope of the cumulative strain-release curve indicates the rate of strain release by earthquakes and, therefore, provides a basis for discussing the mechanism generating a series of earthquakes.

Referring to the Kilauea summit cumulative strain-release index, plate 2, we see that for the two series of earthquakes beginning in April and October, 1953, the curve rises rapidly at first, then more slowly, and finally becomes nearly horizontal. After a strong beginning with a few large earthquakes, these series died out gradually. 
Such a curve characterizes the normal elastic rebound situation, wherein most of the strain slowly accumulated in the rocks of a given region is released by a large earthquake, or at most a few large shocks, and the rest of the strain is released gradually by a declining series of aftershocks.

In contrast, the series of earthquakes at Kilauea caldera that began in March 1954 continued at almost the same intensity until early March 1955. The slope of the cumulative curve is nearly constant throughout this interval. This curve suggests the periodic release of strain rapidly accumulating in a restricted portion of a weak crust, the rate of accumulation of strain being limited by some factor other than the strength of the crust.

Gradual inflation of a reservoir complex only a few kilometers beneath Kilauea caldera by magma welling up from depth, perhaps from the focal zone of the swarms of deep earthquakes and spasmodic tremor about $45 \mathrm{~km}$ beneath the caldera, appears to be the driving force behind the Kilauea summit earthquakes. As the shallow reservoir swells, rocks that encase it are shoved back, and the roof above it is arched upward to allow for its growth. When hydrostatic pressure within the reservoir reaches a critical level, dikes and sills undoubtedly inject the rocks enclosing the reservoir. Both processes, warping of the brittle rocks surrounding the reservoir and splitting open of new fissures through these rocks, would be expected to generate many small earthquakes like those of the Kilauea summit series.

Correlation between the tilt anomaly at the Whitney Laboratory and the progress of the summit earthquake series suggests that the preeruption earthquakes resulted largely from injection of magma into the rocks surrounding the reservoir, since these earthquakes began after inflation of the reservoir was well underway and continued after it ceased altogether. On the other hand, the final swarm of earthquakes in the summit area appears to have been generated by a wholesale reshaping of the rocks surrounding the deflating reservoir. During the first week of rapid collapse the caldera region deformed elastically, as indicated by the accumulation of considerable strain (subsidence) without an increase in earthquakes. After the first week, however, the elastic limit of the rocks composing the summit of Kilauea was exceeded, and further subsidence generated a great swarm of small earthquakes in these rocks.

For east Puna, after an initial jump and rapid leveling off at the time of the severe earthquakes near Kalapana on March 30 , 1954, the cumulative strain-release curve (pl. 3) continually steepened until the opening of the east rift zone south of Pahoa. Sharp increases in the slope of this curve occurred in November 1954, and on February 23, 
1955. The shape of the curve from May 1954 until mid-March 1955 suggests an earthquake-producing mechanism that increased in speed of action with each earthquake. That this mechanism was acting on a small section of a weak crust is indicated by the fact that the earthquakes it produced were quite small.

Beneath the east rift zone, a core of viscous lava more or less in contact at its west end with the conduit feeding lava up into the caldera region, would appear to explain the nature of the eruption-area earthquake swarm. When pressure within the conduit beneath an expanding summit reservoir reached a critical level, magma oozed from the central conduit into the core of the east rift zone, increasing the pressure within the rift-zone core throughout its length. Failure of the rocky carapace over the rift-zone core near Pahoa permitted a dike to begin wedging its way toward the surface. With each advance of the dike, and the earthquake that accompanied it, the confining rocks grew weaker, and with each fresh incursion of lava into the rift-zone core to replace that escaping into the dike the core became more mobile. Thus, a runaway situation developed that was halted only by a drop in pressure within the rift-zone core when the summit reservior was sufficiently depleted by the extrusion of a great deal of lava in Puna.

\section{MECHANISM OF THE ERUPTION}

No verbal description is adequate to present the temporal relationships between earthquakes, harmonic tremor, and tilting of the ground surface at the summit of Kilauea and in the east Puna eruption area. In figure 42 an attempt has been made to display these relationships graphically for the period February 5 through May 31.

Data gathered by the seismograph at Pahoa are plotted in the upper part of the graph (east Puna), and those gathered by instruments near the caldera are plotted in the lower part (Kilauea summit). Earthquakes have been represented by daily strain-release indices for these two regions. At Pahoa, northward tilting corresponds to swelling of the east rift zone south of the station; and at the Whitney Laboratory, southward tilting corresponds to subsidence of the summit of Kilauea southeast of the station. Long-period harmonic tremor generated at the erupting vents was recorded both at Pahoa and at stations around Kilauea caldera. The short-period harmonic tremor that accompanied the most rapid subsidence at the summit of Kilauea was recorded only by sensitive seismographs near the caldera.

Relying on explanations for the earthquake swarms, harmonic tremor, and ground tilting set forth above, we can reconstruct the mechanics of the 1955 eruption on the basis of figure 42 . 
During the lengthy high stand of the summit area, magma oozing from beneath the summit region into the plastic core of the east rift zone inflated the rift zone, and fissures containing magma began to split. upward toward the surface southeast of Pahoa. After several feeble starts in January and early February, the dike fissures split rapidly after February 24 and on February 28 reached the surface and began to discharge lava.

By March 5 the excess pressure within the rift-zone core was practically relieved, and the eruption seemed nearly over. On this date, however, restrictions to the free flow of lava from beneath the summit into the east rift zone broke down. Rapid subsidence of the Kilauea summit and harmonic tremor of local origin suggested a rapid withdrawal of lava from beneath the caldera by March 7. A.

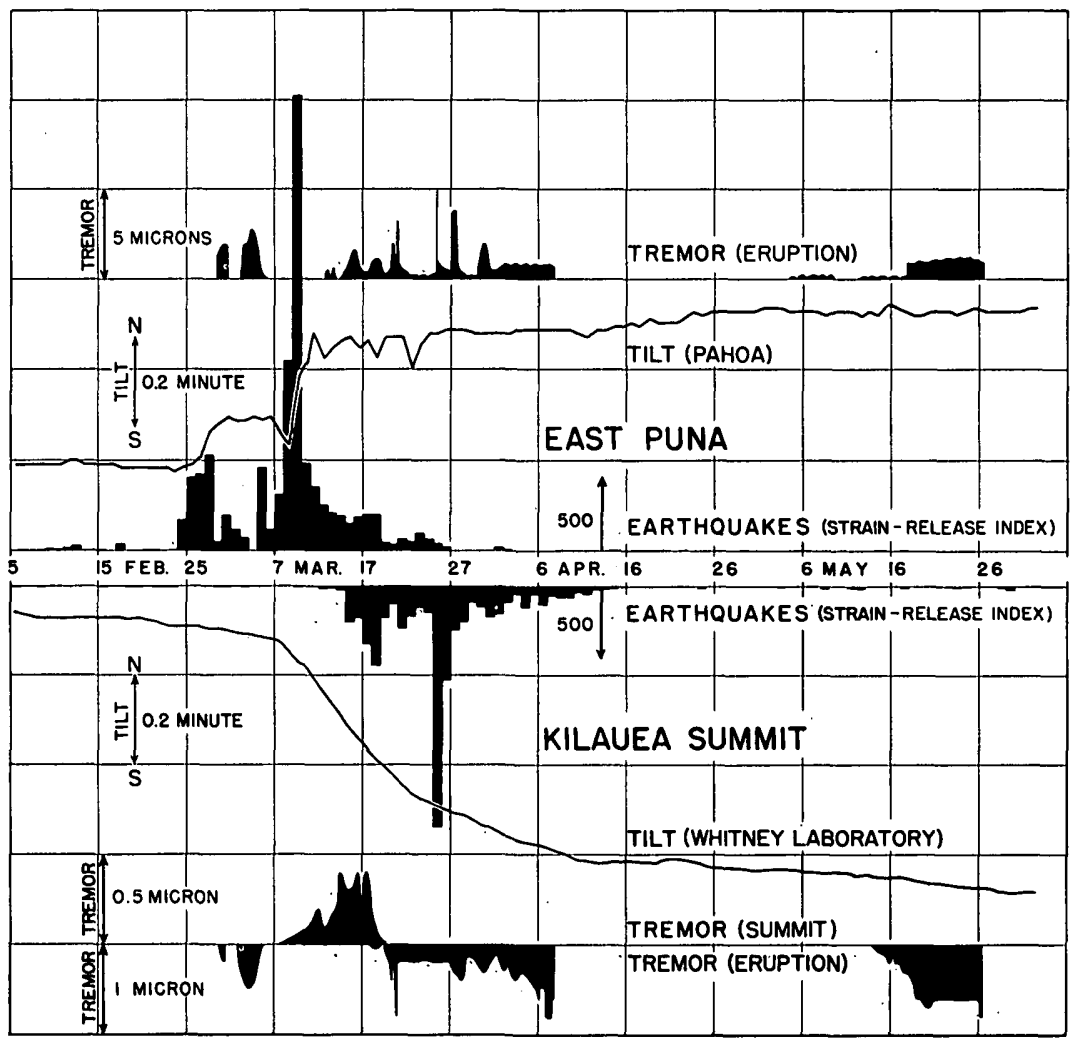

Figurn 42.-Graph correlating earthquakes, tilting, and tremor in east Puna and at the summit of Kilauea for the period February 5 through May 31. Data from the Pahoa seismograph are plotted in the upper part of the figure, and those from instruments at Kilauea caldera are plotted in the lower part. Northward tilting at Pahoa corresponds to swelling of the rift zone south of Pahoa. Southward tilting at the Whitney Laboratory indicates subsidence of the summit of Kilauea. 
renewed swarm of shallow earthquakes and rapid inflation of the rift zone south of Pahoa, from March 8.to 12, indicated lava escaping from the summit region was moving out into the rift zone and was again inflating the rift zone and driving magma-filled fissures toward the surface. Eruption of lava south of Pahoa between March 12 and April 7 again lowered the pressure within the rift-zone core until the eruption ceased. This time, however, the conduits remained open, and when sufficient additional lava had moved into the rift zone, the eruption revived without the opening of new fissures.

Following the cessation of eruptive activity on May 26, so much magma had escaped from beneath the caldera that the difference in pressure beneath the summit of Kilauea and the core of the rift zone was insufficient to reopen channels to the surface. The eruption was over.

\section{LOSSES CAUSED BY THE ERUPTION}

Details of property damage and other losses resulting from the eruption cannot be given here. Detailed statements, including statements of monetary losses, are contained in the reports of the Governor of Hawaii's Puna Volcanic Fact Finding Committee and the Puna Cane Planters' Association. Some of the losses were covered by insurance.

The principal damage is listed below. The acreages are only approximate.

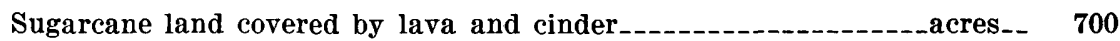

Other cultivated land covered by lava_-

Beach residence lots covered by lava

Forest land covered by lava and cinder.-. 2, 800

Total land covered by lava and cinder

3,900

Sugarcane land burned over but not covered by lava_-_-_-_-_-_-_acres_- 1, 200

Area of other crops burned over but not covered by lava_________do_-_ $\quad 30$

Area of crops seriously damaged by sulfur fumes_-_-_-_-_-_-_-_do_-_- $\quad \mathbf{4 5}$

Homes destroyed

Homes rendered uninhabitable

Homes moved because sites rendered uninhabitable

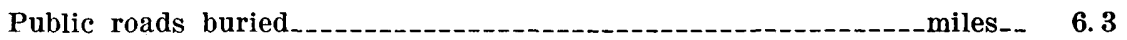

Despite the fact that the eruption occurred in an inhabited area, there were no human casualties. The loss of movable property also was very small, owing to advance warning and prompt evacuation.

\section{REOCCUPATION OF THE AREA BY ORGANISMS}

Both marine life and land plants started to invade the new flows with surprising rapidity. By late June 1955, algae were abundant in and just below the tidal zone on the ends of the flows that had 
entered the ocean, and both limpets (Helcioniscus exaratus) and periwinkles (Littorina pindato) could be found on the rocks. Fish were abundant in the water around the new flows.

By early September lichens, mosses, ferns, and some higher plants were taking root in the craters of some of the cones, particularly where a small amount of escaping steam provided heat and moisture. The first invaders were plants with light seeds or spores easily transported by the wind. By the early spring of 1956 plants also were beginning to make their appearance at isolated spots on the outer slopes of the cones and on the flow surfaces away from the vents. In the warm moist climate prevailing in east Puna, the flows will be well vegetated within a few tens of years. The nearby flows of 1840 are heavily covered with vegetation.

Particularly noteworthy is the rapid development of grass and other plants along the shoulders of roads across the new flows. This undoubtedly is due partly to seeding by traffic over the road, but also in large part it appears to be the result of crushing of the new lava sufficiently to enable it to hold more moisture. Observations such as this.hold promise for the development of methods for speeding the revegetation of flows and transforming them again into useful land.

\section{EARTHQUAKE' TRAVELTIMES AND CRUSTAL STRUCTURE IN HAWAII}

Expansion and refinement of the Hawaiian seismograph network during 1953 and 1954 raised the quality of earthquake observations to the level at which studies of earthquake traveltimes in Hawaii could be based on reasonably reliable data. However, the sensitivity of most of the seismographs in operation was rather low, and only the largest earthquakes associated with the 1955 eruption were recorded to sufficient distances to permit traveltime studies.

Time control at stations on Hawaii was provided by IBM type 25 Master clocks, with radio time signals (WWVH) recorded once daily directly on the seismograms to furnish clock corrections. Somewhat irregular drum advance at the stations equipped with mechanical seismographs possibly introduced errors as large as 0.5 second in some readings, but the overall timing accuracy is believed to be within 0.2 second.

The three earthquakes analyzed in this section were selected because they were large enough to be recorded at distances of several hundred kilometers and beeause they were so located that a somewhat symmetrical deployment of seismograph stations around their origins facilitated determination of their epicenters. Observed wave arrivals for each quake and the traveltime curves determined by these arrivals 
are presented in figures $43,44,45$. Because heavy reliance was placed on wave arrivals after the first, especially on the low-magnification mechanical seismographs, the recorded double amplitude, in millimeters, is indicated beside the point representing the arrival of waves at stations equipped with the mechanical seismographs. Correlation of a particular wave from one station to the next was made more certain by such amplitude data.

Epicenters for these earthquakes were determined by a systematic revision of preliminary epicenters obtained with the aid of provisional traveltime curves. Those finally selected were the ones for which the observed wave arrivals best fit the traveltime curves drawn through them by inspection.

For the interpretation of the traveltime curves, a simple model of the earth's crust consisting of homogeneous flat-lying layers with velocity increasing from layer to layer downward has been assumed. That such a model might not be adequate to represent the structure of the Hawaiian ridge is obvious but it will serve as a convenient vehicle for analyzing the data so far available.

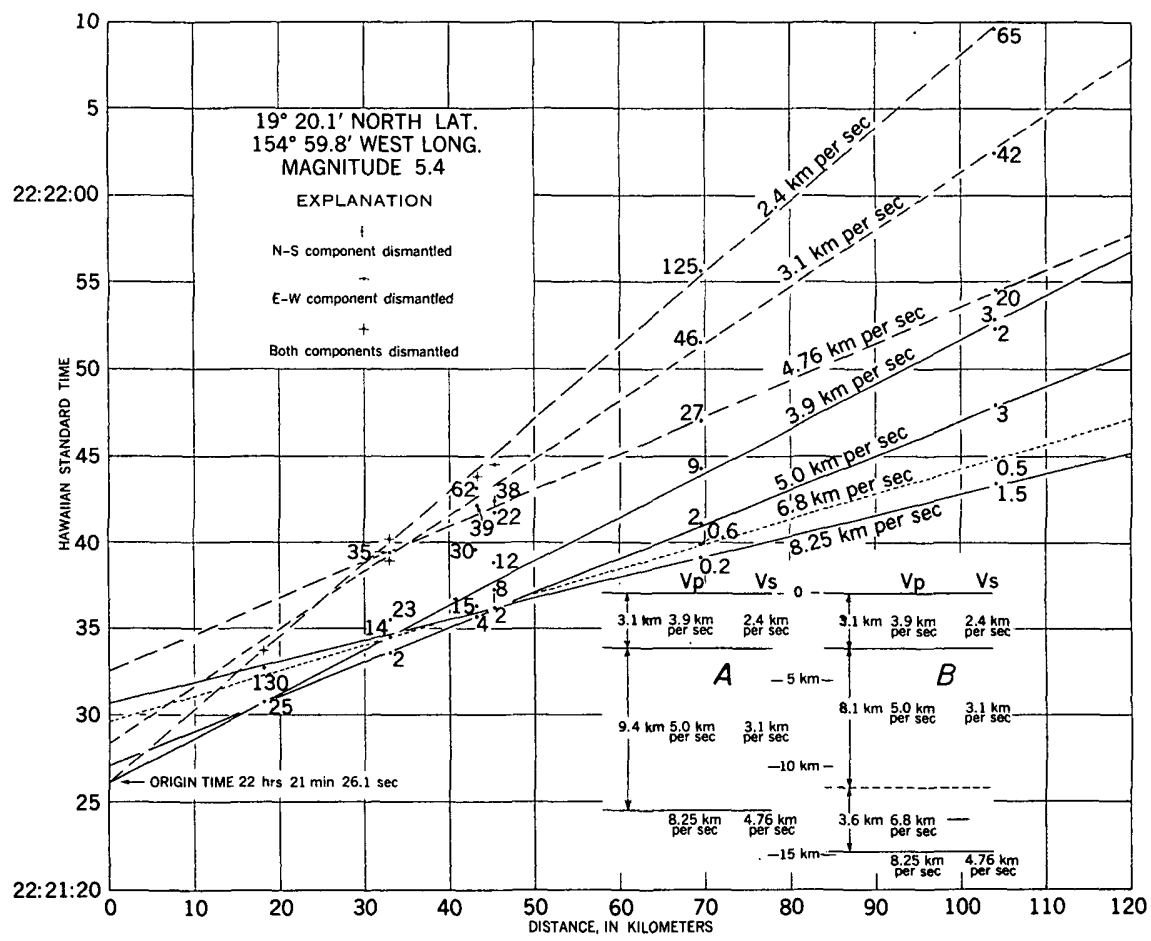

Figure 43.-Traveltime curves for the earthquake of March 7, 1955, and the crustal structure deduced from the $P$-wave curves. In case $A$ the questionable $6.8 \mathrm{~km}$ per sec arrival is rejected, and in case $B$ it is accepted as real. 
For a crust consisting of three layers of thickness $d_{1}, d_{2}$, and $d_{3}$, with $P$ velocities $v_{1}, v_{2}$, and $v_{3}$, lying on a mantle with a $P$ velocity $v_{n}$, traveltimes of the direct and three refracted $P$ waves from an earthquake with a surface focus are:

$$
h=0\left\{\begin{array}{l}
t_{1}=\frac{\Delta}{v_{1}} \\
t_{2}=\frac{\Delta}{v_{2}}+\frac{2 d_{1} \cos \theta_{2}^{1}}{v_{1}}, \text { where } \sin \theta_{2}^{1}=\frac{v_{1}}{v_{2}} \\
t_{3}=\frac{\Delta}{v_{3}}+\frac{2 d_{1} \cos \theta_{3}^{1}}{v_{1}}+\frac{2 d_{2} \cos \theta_{3}^{2}}{v_{2}}, \text { where } \sin \theta_{3}^{1}=\frac{v_{1}}{v_{3}} \text { and } \sin \theta_{3}^{2}=\frac{v_{2}}{v_{3}} \\
t_{n}=\frac{\Delta}{v_{n}}+\frac{2 d_{1} \cos \theta_{n}^{1}}{v_{1}}+\frac{2 d_{2} \cos \theta_{n}^{2}}{v_{2}}+\frac{2 d_{3} \cos \theta_{n}^{3}}{v_{3}}
\end{array}\right.
$$

where $\sin \theta_{n}^{1}=\frac{v_{1}}{v_{n}}, \sin \theta_{n}^{2}=\frac{v_{2}}{v_{n}}$, and $\sin \theta_{n}^{3}=\frac{v_{3}}{v_{n}}$ and $\Delta$ is the epicentral distance.

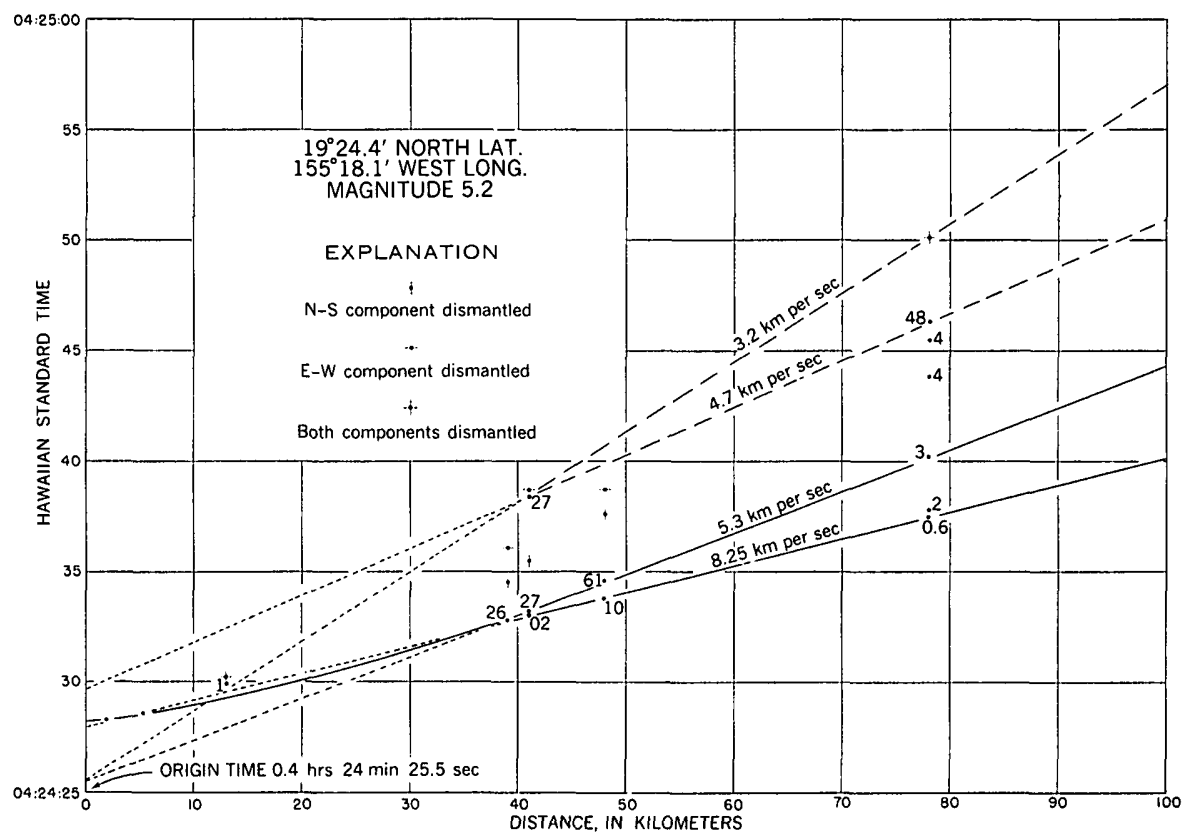

Fiadre 44.-Traveltime curves for the earthquake of April 1, 1955. 
If the focus were within the second layer at a depth $h$ from the surface, there should be no wave arrival with velocity $v_{1}$; and the asymptote to the traveltime curve of the direct $P$ wave (through the second layer) and the traveltimes of the two refracted $P$ waves should be:

$$
d_{1}<h<d_{1}+d_{2}\left\{\begin{aligned}
\left(t_{2}\right)_{a} & =\frac{\Delta}{v_{2}}+\frac{d_{1} \cos \theta_{2}^{1}}{v_{1}} \\
t_{3} & =\frac{\Delta}{v_{3}}+\frac{\left(2 d_{2}-h\right) \cos \theta_{3}^{2}}{v_{2}}+\frac{d_{1} \cos \theta_{3}^{1}}{v_{1}} \\
t_{n} & =\frac{\Delta}{v_{n}}+\frac{2 d_{3} \cos \theta_{n}^{3}}{v_{3}}+\frac{\left(2 d_{2}-h\right) \cos \theta_{3}^{2}}{v_{2}}+\frac{d_{1} \cos \theta_{n}^{1}}{v_{1}}
\end{aligned}\right.
$$

where the angles are defined as above. Moreover, the first arrival at the epicenter should occur at a time $\frac{d_{1}}{v_{1}}+\frac{h-d_{1}}{v_{2}}$.

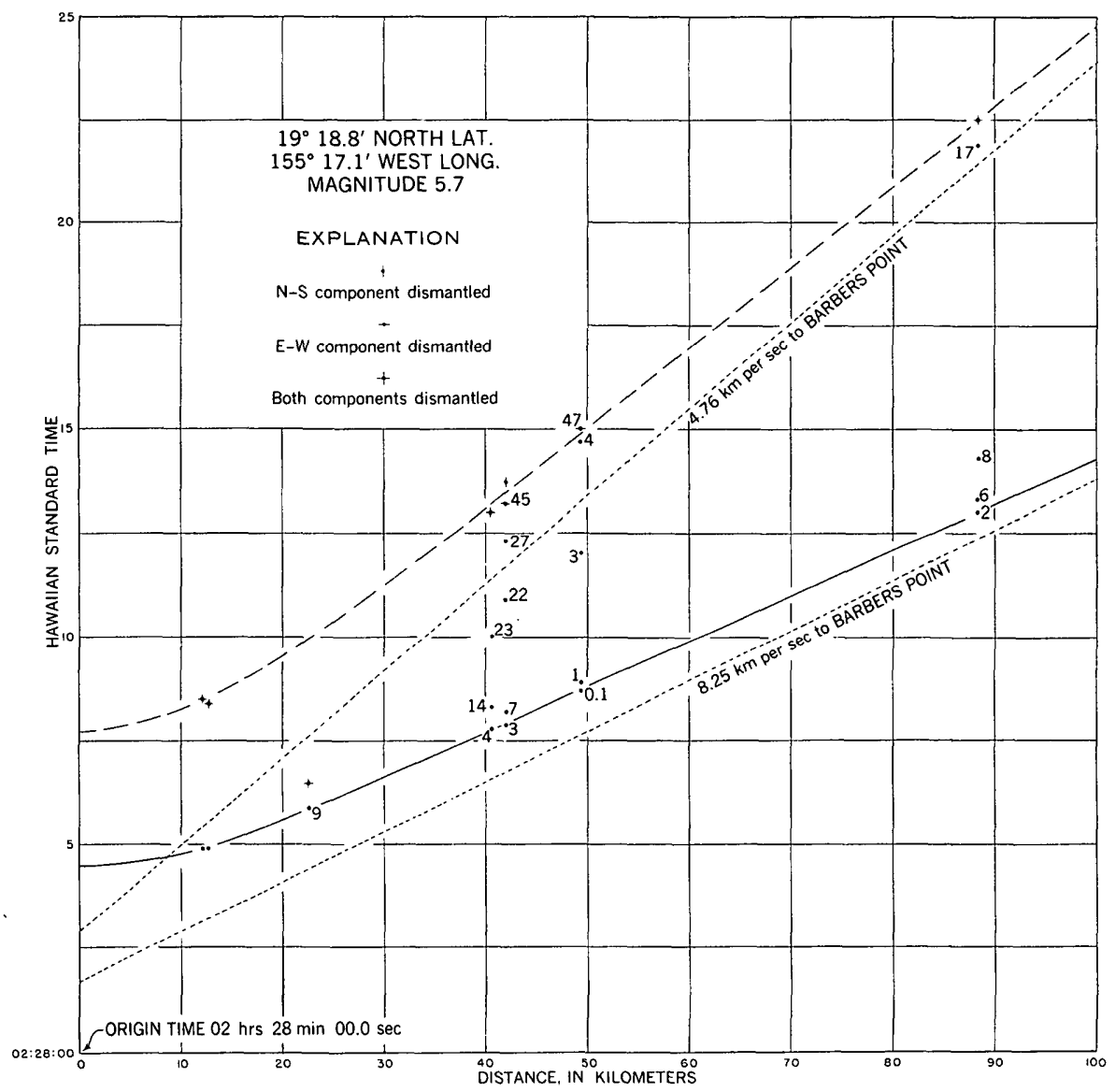

Figdre 45.-Traveltime curves for the earthquake of August 14, 1955. 
If the focus were within the mantle at a depth $h\left(h>d_{1}+d_{2}+d_{3}+d_{4}\right)$, there should be no waves with velocities $v_{1}, v_{2}$, or $v_{3}$. Only the direct $P$ wave (through the mantle) should appear, and the asymptote to its traveltime curve should be:

$$
h>d_{1}+d_{2}+d_{3} ;\left(t_{n}\right)_{a}=\frac{\Delta}{v_{n}}+\frac{d_{3} \cos \theta_{n}^{3}}{v_{3}}+\frac{d_{2} \cos \theta_{n}^{2}}{v_{2}}+\frac{d_{1} \cos \theta_{n}^{1}}{v_{\mathfrak{l}}},
$$

where the angles are as defined above. The first arrival of this wave at the surface should be at a time

$$
\frac{d_{1}}{v_{1}}+\frac{d_{2}}{v_{2}}+\frac{d_{3}}{v_{3}}+\frac{h-d_{1}-d_{2}-d_{3}}{v_{n}}
$$

If we let capital $V$ 's and $T$ 's represent velocities and traveltimes, respectively, for $S$ waves, the foregoing equations can be taken over for $S$ waves by replacing $t$ by $T$ and $v$ by $V$.

Each traveltime curve (or asymptote) is characterized by its slope (the coefficient of $\triangle$ ) and by its intercept (the value of time at $\Delta=0)$. We might note, also, that the intercept of the asymptote to $t_{n}$ for an earthquake with its focus in the mantle is just one-half the intercept of $t_{n}$ for an earthquake with surface focus.

To determine the thickness and wave velocities of layers composing the simple crustal model treated here, it would suffice to have traveltime curves for a surface focus earthquake. Letting $\Delta=0$ in the traveltime equations for a surface focus earthquake, the equations for $t_{2}, t_{3}$, and $t_{n}$ become equations for $h_{1}, h_{2}$, and $h_{3}$ if we have the layer velocities and traveltime curve intercepts from the traveltime graph of an actual earthquake. Unfortunately, shallow earthquakes are usually quite small, and they provide poor data on the waves refracted through the deeper layers. Furthermore, unless a seismograph is located at or very near the epicenter, small focal depth (within the first layer) cannot be detected by inspection of the traveltime curves but will lead to an estimate of the thickness of the first layer too small by half of the focal depth.

Earthquakes occurring within the mantle are particularly interesting because they present a sharp, uncomplicated record and because the intercepts of the asymptote to $t_{n}$ and $T_{n}$ are just one-half those expected for earthquakes with surface foci.

The earthquake of intermediate focal depth treated herein gave strong, clear arrivals through the main second crustal layer and through the upper portion of the mantle.

The magnitude 5.4 earthquake at $22^{\mathrm{h}} 21^{\mathrm{m}} 26.1^{\mathrm{s}}$ on March 7 was felt over the entire south half of the island of Hawaii. It originated at 
a shallow depth along the south shore of Hawaii about 3 miles southwest of Kalapana. Well-developed $P$ and $S$ waves through two layers above the Mohorovicic discontinuity as well as feeble $P$ and $S$ waves through the mantle can be discerned on the traveltime graph (fig. 43) of this earthquake. A small second arrival at stations beyond $50 \mathrm{~km}$ (including Barbers Point at $390 \mathrm{~km}$ ) suggests another $P$ wave through a probable third layer above the mantle. The origin time adopted for this earthquake was that at which the direct $P$ wave $(3.9 \mathrm{~km}$ per sec) crossed the time axis at zero distance.

An intermediate depth earthquake of magnitude 5.2 that originated beneath Kilauea caldera at $4^{\mathrm{h}} 24^{\mathrm{m}} 25.5^{\mathrm{s}}$ on April 1 was felt generally on Hawaii and by a few persons on Maui and Oahu. Its traveltime graph (fig. 44) shows strong wave arrivals through the upper mantle and through one layer above it. Since the focus of this earthquake lay beneath the uppermost layer revealed by the March 7 earthquake, no waves through this layer are to be expected. Arrivals through the third layer cannot be identified at stations on Hawaii, but a $P$ wave that probably followed a path through this layer appears on the Barbers Point seismogram. The origin time adopted for this earthquake was that at which the asymptote to the direct $P$ wave curve (second layer) crossed the time axis at zero distance. If the first layer suggested by the March 7 earthquake were allowed for, an origin time 0.5 second earlier should have been taken.

A magnitude 5.7 earthquake from a focus nearly $30 \mathrm{~km}$ beneath the Hilina fault system south of Kilauea caldera at $2^{\text {h }} 28^{\mathrm{m}} 00.0^{\mathrm{s}}$ on August 14 was felt generally on Hawaii and by a few persons as far away as Kauai. Originating far below the Mohorovicic discontinuity, it produced no waves that were refracted through the crustal layers above the mantle. Only one set of $P$ and $S$ arrivals appear on its traveltime graph (fig. 45), and the curves drawn through them approach asymtotes with slopes corresponding to velocities of $8.25 \mathrm{~km}$ per sec and 4.76 $\mathrm{km}$ per sec, respectively, which pass through the strong $P$ and $S$ arrivals at the Barbers Point station $367 \mathrm{~km}$ from the epicenter. Values for the apparent origin time computed from $P$ and $S$ arrivals at each station were unusually consistent, and the average of these was accepted as the origin time of the earthquake.

Table 6 summarizes the data on these three earthquakes and their traveltime graphs. On the basis of the simple crustal model discussed above, we can compute the thickness of the layers and the depth to the Mohorovicic discontinuity from the traveltime curves of the shallow March 7 quake. Case $A$ (fig. 43) was computed from $P$-wave traveltime curves of this quake on the assumption that only the two uppermost layers exist. On this basis the Mohorovicic discontinuity lies 
only $12.5 \mathrm{~km}$ below sea level under Hawaii. Case $B$ (fig. 43) was computed from the same data on the assumption that the third layer is real. On this basis the depth to the Mohorovicic discontinuity is $14.8 \mathrm{~km}$. The thickness of $3.6 \mathrm{~km}$ obtained for the third layer is somewhat less than that of the layer with a comparable $P$ velocity that floors the Pacific basin.

TABLE 6.-Data on crustal layers in Hawaii

\begin{tabular}{|c|c|c|c|c|c|c|c|}
\hline \multicolumn{2}{|c|}{$\begin{array}{l}\text { Earthquake. } \\
\text { Epicenter } \\
\text { Origin time } \\
\text { Focal depth. } \\
\text { Magnitude. }\end{array}$} & \multicolumn{2}{|c|}{$\begin{array}{l}\text { March } 7,1955 \\
\text { lat } 19^{\circ} 20^{\prime} 1^{\prime} \mathrm{N} \cdot{ }^{\prime} \\
\text { long } 154^{\circ} 49.8^{\prime} \mathrm{W} \text {. } \\
22^{\mathrm{h}} 21^{\mathrm{m}} 26.1^{\circ} \\
\text { Shallow } \\
5.4\end{array}$} & \multicolumn{2}{|c|}{$\begin{array}{l}\text { April 1, } 1855 \\
\text { lat } 19^{\circ} 24.4^{\prime} \mathrm{N} \cdot \mathrm{h} \\
\log ^{\prime} 155^{\circ} 18.3^{\prime} \mathrm{W} \text {. } \\
4^{\mathrm{h}} 24 \mathrm{~m} 25.5^{\circ} \\
10 \mathrm{~km} \\
5.2\end{array}$} & \multicolumn{2}{|c|}{$\begin{array}{l}\text { August 14, } 1955 \\
\text { lat } 19^{\circ} 18.8^{\prime} \mathrm{N} \cdot \mathrm{l} \\
\text { long } 155^{\circ} 17.1^{\prime} \mathrm{W} \text {. } \\
2^{\mathrm{h}} 28^{\mathrm{m}} 00.0^{\circ} \\
29 \mathrm{~km} \\
5.7\end{array}$} \\
\hline \multirow{2}{*}{ Layer } & \multirow{2}{*}{ Traveltime Parameters } & \multicolumn{6}{|c|}{ Wave } \\
\hline & & $\boldsymbol{P}$ & $S$ & $\boldsymbol{P}$ & $\boldsymbol{S}$ & $\boldsymbol{P}$ & $\mathbf{S}$ \\
\hline $\begin{array}{l}\text { I } \\
\text { II } \\
\text { III } \\
\text { Mantle }\end{array}$ & $\begin{array}{l}\text { Veloc (km per sec) } \\
\text { Intercept (sec) } \\
\text { Veloc (km per sec) } \\
\text { Intercept (sec) } \\
\text { Veloc (km per sec) } \\
\text { Intercept (sec) } \\
\text { Veloc (km per sec) } \\
\text { Intercept (sec) }\end{array}$ & $\begin{array}{l}3.9 \\
0 \\
5.0 \\
1.0 \\
6.8 \\
3.5 \\
8.25 \\
4.6\end{array}$ & $\begin{array}{l}2.4 \\
0 \\
3.1 \\
2.3 \\
14.76 \\
6.4\end{array}$ & 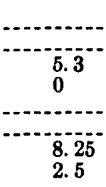 & $\begin{array}{l}3.2 \\
4.70 \\
4.2\end{array}$ & 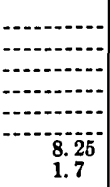 & 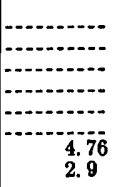 \\
\hline \multicolumn{2}{|c|}{$\begin{array}{l}\text { Layers represented by wave arrivals at } \\
\text { Barbers Point ( }>360 \mathrm{~km} \text { from epicenter) }\end{array}$} & $\begin{array}{l}\text { I? II, } \\
\text { III, } \\
\text { Man- } \\
\text { tle. }\end{array}$ & $\begin{array}{l}\text { III? } \\
\text { Mle }\end{array}$ & $\begin{array}{c}\text { II, III, } \\
\text { Man- } \\
\text { tle }\end{array}$ & Mantle & Mantle & Mantle \\
\hline
\end{tabular}

1 Nominal velocity: data too poor to determine accurate value.

Although the traveltime graph for the April 1 earthquake is an inadequate basis on which to compute the structure of the crust, it provides a check on wave velocities in the second layer. The slightly higher second layer $P$ and $S$ velocities suggested by this earthquake might result either from an increase in velocity downward within the second layer or from a sloping contact between the second and deeper layers. If we assume a focal depth of $10 \mathrm{~km}$ for this earthquake, its observed wave arrivals are in good agreement with those computed from the 3-layer (case $B$ ) structure deduced from the March 7 earthquake data.

For a focal depth of $29 \mathrm{~km}$, the August 14 wave arrivals at stations on Hawail are in good agreement with the case $B$ structure. The intercept of the asymptote to the $P_{n}$ curve is somewhat less than one-half of that for the March 7 earthquake, confirming that the latter was shallow. Because the $P_{n}$ asymptote for the August 14 earthquake was projected backwards from Barber's Point, $367 \mathrm{~km}$ from the epicenter, its intercept is extremely sensitive to the velocity of $P$ in the upper 
mantle. To increase the asymptote to $2.0 \mathrm{sec}$ would require a velocity of $8.30 \mathrm{~km}$ per sec, however. It would thus appear that the March 7 $P_{n}$ intercept is somewhat too large, and that the total thickness of the crustal layers computed from the March 7 data is a little too great.

Although seismic evidence for the existence of the third layer is not compelling, it appears that the three-layer crust (case $B$ ) computed from the traveltime curves of the March 7 earthquake is a better representation of Hawaiian crustal structure than the two-layer crust (case $A$ ). Until more information becomes available the case $B$ structure will be adopted for Hawaii.

\section{HAWAIIAN VOLCANO OBSERVATORY SUMMARY FOR 1955}

\section{SEISMOGRAPHS AND TILTMETERS}

The seismograph and tilt measuring stations in operation at the end of 1954 were continued almost without change throughout the year. From December 1954 to August 1955 three additional seismographs were operated in the basement of Eaton's house near the northeast rim of Kilauea caldera. These three instruments, all oriented to record the north-south component of earth motion, had widely different characteristics and were set up to probe the regional microseism background to determine which types of seismograph are best suited for use on the island of Hawaii. The stations are listed and the characteristics of the instruments given in table 7. The locations of the stations on the island of Hawaii are shown in figures 1 and 46.

During August a water-tube tiltmeter was installed in the Whitney Laboratory of Seismology. This instrument, built in the Observatory shop, closely resembles instruments that have been operated for several years by the Earthquake Research Institute of Tokyo University (Hagiwara, 1948, p. 28). Three vessels, approximately 4 inches in inside diameter, are connected near the base by one-half inch tubes 16 feet long, the tubes being placed respectively in the north-south and east-west azimuths. The vessels are filled with water to about the middle of viewing windows in their sides. Other windows on the opposite sides of the vessels permit light from a source behind them to shine through the vessels. A micrometer protrudes through the bottom of each vessel up into the liquid, and by means of a magnifying lens in the front window the contact of a needle point on the end of the micrometer stem with the liquid surface can be detected visually with great precision. The position of the point is then read on the micrometer dial. Any tilting of the surface on which the vessels rest causes liquid to run from one vessel to the other, and the amount of this liquid 

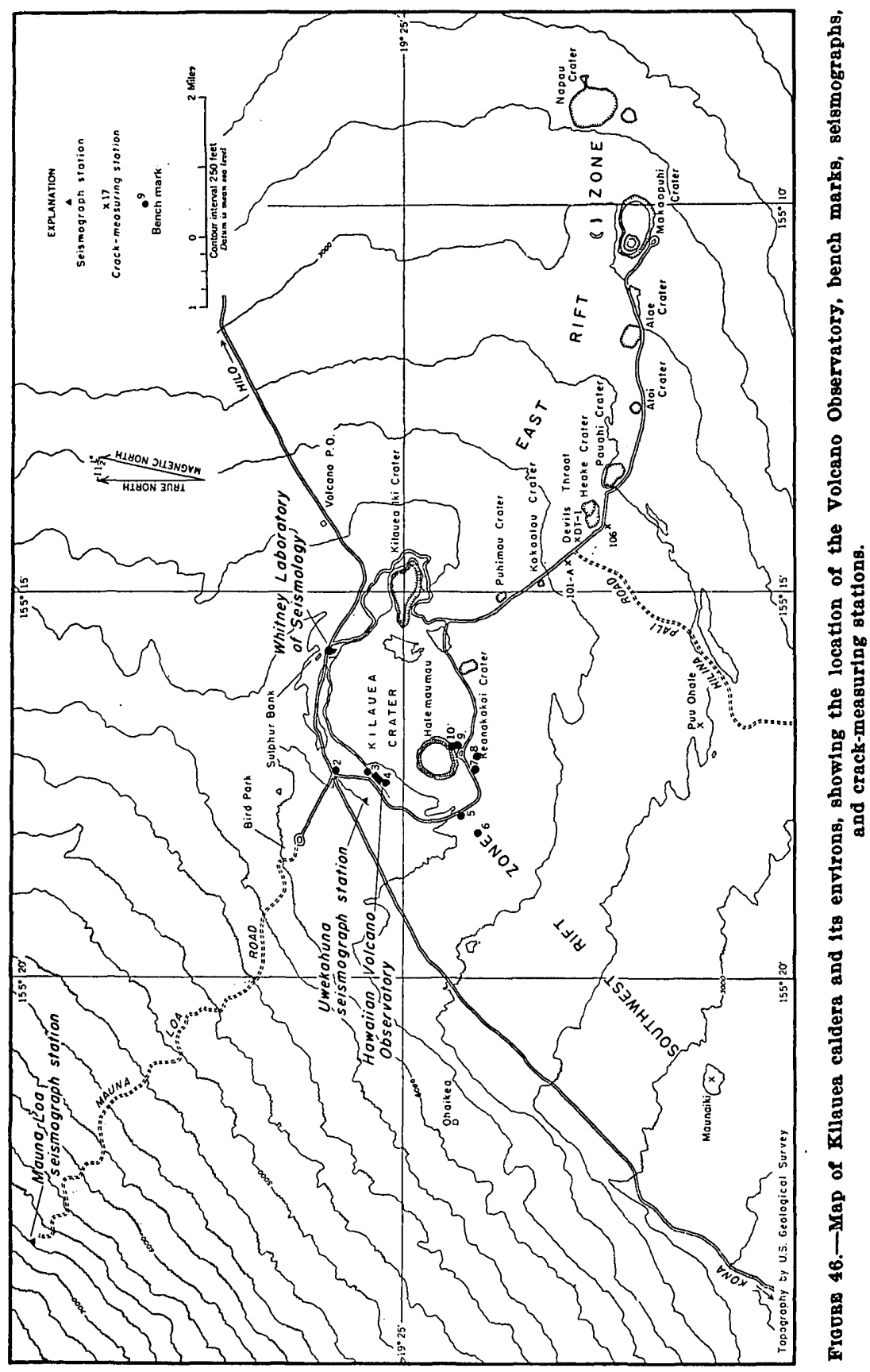
transfer can be determined by reading the level of the liquid surface in each vessel. As the instrument is operating in the Whitney Laboratory, a change of 1 division on the micrometer scale is equivalent to approximately 1.0 second of tilting. The vessels are covered to retard evaporation and entry of dust, and the tops are interconnected with a one-quarter inch tube to maintain uniform saturation of the air above the liquid and prevent the formation of a partial vacuum in one vessel as liquid drains from it to the others. Construction and operation of the water-tube tiltmeters has been discussed in more detail elsewhere (Eaton, 1959).

TABLE 7.-Seismographs and tiltmeters operated by the Hawaiian Volcano observatory during 1955

\begin{tabular}{|c|c|c|c|c|c|c|}
\hline Station & $\begin{array}{l}\text { Latitude } \\
\text { (north) }\end{array}$ & $\begin{array}{l}\text { Longitude } \\
\text { (west) }\end{array}$ & Instrument & $\begin{array}{c}\text { Period } \\
\text { of } \\
\text { pendu- } \\
\text { lum } \\
\text { (sec- } \\
\text { onds) }\end{array}$ & $\begin{array}{c}\text { Peak } \\
\text { magni- } \\
\text { fica- } \\
\text { tion } \\
\text { (ap- } \\
\text { proxi- } \\
\text { mate) }\end{array}$ & $\begin{array}{l}\text { Sensi- } \\
\text { tivity } \\
\text { to tilt } \\
\text { (sec- } \\
\text { onds of } \\
\text { arc per } \\
\text { mm) }\end{array}$ \\
\hline $\begin{array}{l}\text { Whitney Laboratory of Seis- } \\
\text { mology (northeast rim of } \\
\text { Kilauea caldera). }\end{array}$ & $19^{\circ} 25^{\prime} 53^{\prime \prime}$ & $155^{\circ} 15^{\prime} 40^{\prime \prime}$ & $\begin{array}{l}\text { Bosch-Omori seismo- } \\
\text { graph and tiltmeter }\end{array}$ & 7.7 & 115 & 0.12 \\
\hline $\begin{array}{l}\text { Uwekahuna (1,000 feet west } \\
\text { of west rim of Kilauea cal- } \\
\text { dera). }\end{array}$ & $\begin{array}{l}19^{\circ} 25^{\prime} 53^{\prime \prime} \\
19^{\circ} 25^{\prime} 26^{\prime \prime}\end{array}$ & $\begin{array}{l}155^{\circ} 15^{\prime} 40^{\prime \prime} \\
155^{\circ} 17^{\prime} 36^{\prime \prime}\end{array}$ & $\begin{array}{l}\text { Water-tube tiltmeter.- } \\
\text { Sprengnether vertical } \\
\text { seismograph. }\end{array}$ & 1.5 & 1,750 & .1 \\
\hline Do........ & $19^{\circ} 25^{\prime} 26^{\prime \prime}$ & $155^{\circ} 17^{\prime} 36^{\prime \prime}$ & Jaggar vertical seismo- & .4 & 250 & \\
\hline Do..... & $19^{\circ} 25^{\prime} 26^{\prime \prime}$ & $155^{\circ} 17^{\prime} 36^{\prime \prime}$ & $\begin{array}{l}\text { North-south and east- } \\
\text { west horizontal pen- } \\
\text { dulum tiltmeters. }\end{array}$ & 20.0 & 7 & .32 \\
\hline $\begin{array}{l}\text { Hawaiian Volcano Observa- } \\
\text { tory (west rim of Kilauea } \\
\text { caldera). }\end{array}$ & $19^{\circ} 25^{\prime} 21^{\prime \prime}$ & $155^{\circ} 17^{\prime} 23^{\prime \prime}$ & Imamura seismograph & 3.0 & 15 & \\
\hline $\begin{array}{l}\text { Eaton residence (northeast } \\
\text { rim of Kilauea caldera) }\end{array}$ & $19^{\circ} 25^{\prime} 38^{\prime \prime}$ & $155^{\circ} 15^{\prime} 31^{\prime \prime}$ & Wood-Anderson. & .8 & 2,800 & \\
\hline Do & $19^{\circ} 25^{\prime} 38^{\prime \prime}$ & $155^{\circ} 15^{\prime} 31^{\prime \prime}$ & Sprengnether short- & 2.5 & 10,000 & \\
\hline Do... & $19^{\circ} 25^{\prime} 38^{\prime \prime}$ & $155^{\circ} 15^{\prime} 31^{\prime \prime}$ & Sprengnether long- & 310.0 & 500 & \\
\hline $\begin{array}{l}\text { Mauna Loa (altitude } 6,600 \\
\text { feet on east slope of Mauna } \\
\text { Loa). }\end{array}$ & $19^{\circ} 29^{\prime} 32^{\prime \prime}$ & $155^{\circ} 23^{\prime} 29^{\prime \prime}$ & $\begin{array}{l}\text { Loucks-Omori seis- } \\
\text { mograph. }\end{array}$ & 3.0 & 200 & .46 \\
\hline Hilo (St. Joseph's School) . . . . & $19^{\circ} 43^{\prime} 11^{\prime \prime}$ & $155^{\circ} 05^{\prime} 20^{\prime \prime}$ & do. & 3.0 & 175 & .48 \\
\hline $\begin{array}{l}\text { Pahoa (Pahoa School) } \\
\text { Naalehu (Naalehu School) }\end{array}$ & $\begin{array}{l}19^{\circ} 29^{\prime} 39^{\prime \prime} \\
19^{\circ} 03^{\prime} 48^{\prime \prime}\end{array}$ & $\begin{array}{l}154^{\circ} 56^{\prime} 47^{\prime \prime} \\
155^{\circ} 35^{\prime} 10^{\prime \prime}\end{array}$ & $\begin{array}{l}\text { do } \\
\text { do }\end{array}$ & $\begin{array}{l}3.0 \\
3.0\end{array}$ & $\begin{array}{l}200 \\
200\end{array}$ & 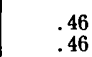 \\
\hline $\begin{array}{l}\text { Kona (Konawaena School, } \\
\text { Kealakekua). }\end{array}$ & $19^{\circ} 30^{\prime} 47^{\prime \prime}$ & $155^{\circ} 55^{\prime} 07^{\prime}$ & $\begin{array}{l}\text { Hawaiian-type seis- } \\
\text { mograph. }\end{array}$ & 7.3 & 115 & .13 \\
\hline $\begin{array}{l}\text { Kamuela (Waimea School, } \\
\text { Kamuela). }\end{array}$ & $20^{\circ} 01^{\prime} 20^{\prime \prime}$ & $155^{\circ} 40^{\prime} 18^{\prime \prime}$ & $\begin{array}{l}\text { Loucks-Omori seis- } \\
\text { mograph. }\end{array}$ & 3.0 & 200 & .46 \\
\hline $\begin{array}{l}\text { Outlet (south edge of Kilauea } \\
\text { caldera). }\end{array}$ & $19^{\circ} 23^{\prime} 21^{\prime \prime}$ & $155^{\circ} 17^{\prime} 10^{\prime \prime}$ & $\begin{array}{l}\text { Experimental vertical } \\
\text { seismograph. }\end{array}$ & 1.0 & 10,000 & \\
\hline $\begin{array}{l}\text { Southeast tilt cellar (floor of } \\
\text { Kilauea caldera southeast of } \\
\text { Halemaumau). }\end{array}$ & $19^{\circ} 24^{\prime} 20^{\prime \prime}$ & $155^{\circ} 16^{\prime} 59^{\prime \prime}$ & $\begin{array}{l}\text { Normal pendulum } \\
\text { tiltmeter. }\end{array}$ & 3.0 & 100 & 1.3 \\
\hline $\begin{array}{l}\text { West tilt cellar (floor of Kil- } \\
\text { auea caldera west of Hale- } \\
\text { maumau). }\end{array}$ & $19^{\circ} 24^{\prime} 32^{\prime \prime}$ & $155^{\circ} 17^{\prime} 33^{\prime \prime}$ & do _.. & 3.0 & 100 & 1.3 \\
\hline Haleakala (Island of Maui) & $20^{\circ} 45^{\prime} 57^{\prime \prime}$ & $156^{\circ} 14^{\prime} 58^{\prime \prime}$ & $\begin{array}{l}\text { Loucks-Omori seis- } \\
\text { mograph. }\end{array}$ & 3.0 & 200 & .46 \\
\hline
\end{tabular}

1 Galvanometer period 1.5 seconds.

2 Galvanometer period 0.5 second.

3 Galvanometer period 38.0 seconds. 
By the end of the year the tilting indicated by the water-tube tiltmeter appeared to be similar to that indicated by the horizontal pendulum of the Bosch-Omori seismograph, but operation had not continued long enough to give a good comparison.

Late in the year a vertical electromagnetic seismograph designed and built by Eaton was placed in the new vault near the south edge of $\mathrm{Ki}$ lauea caldera. The signal from this instrument is amplified and transmitted over wires to the Volcano Observatory, about 2.5 miles away. There it is recorded on a drum covered with smoked paper, revolving at a rate of $60 \mathrm{~mm}$ per minute, by means of a Brush pen-motor. For higher speeds of paper motion the signal can be recorded by means of an ink pen on a Brush recorder.

Also late in the year, the Loucks-Omori seismograph was removèd from the Haleakala station preparatory to remodeling the station for the installation of optically recording seismographs.

\section{EARTHQUAKE STATISTICS}

The Bosch-Omori seismograph in the Whitney Laboratory of Seismology recorded approximately 4,650 earthquakes during 1955 . The more sensitive Sprengnether vertical seismograph in the Uwekahuna station recorded a much greater number. The number of quakes recorded per week on the Bosch-Omori seismograph ranged from 0 to approximately 2,667 . The number of quakes and the weekly seismicity are given in table 8. (For a discussion of local seismicity, see Macdonald and Eaton, 1955b, p. 140.) The local seismicity per week ranged from 0 to approximately 698 .

Through January and February both the total number of earthquakes per week and the weekly seismicity value were almost continuously well in excess of the norms for the 20-year period, 1934-1953 (Macdonald and Eaton, idem). The excess reflects a continuation of the marked uneasiness of Kilauea that had existed in 1954 (Macdonald and Eaton, 1957), an uneasiness that culminated on February 28 with eruption on the east rift zone. Seismicity at the Pahoa station was even greater than in the caldera region (fig. 42 ).

The very large numbers of earthquakes and high seismicity values in late March and early April mark a period of subsidence of the summit of Kilauea that accompanied the outpouring of lava in eastern Puna.

\section{LOCAL EARTHQUAKES}

Table 9 lists data for local earthquakes determined from seismographs operated by the Hawaiian Volcano Observatory on the islands 
of Hawaii and Maui. Except for smaller earthquakes of special interest; only earthquakes classed as slight or larger were included in the list. The intensity ratings assigned are based on the Bosch-Omori seismograph at the Whitney Laboratory. The intensity scale has been extended empirically to permit its use with the Loucks-Omori and Sprengnether seismographs.

Many of the earthquakes occurring on the east rift of Kilauea near Pahoa were felt in the epicentral area. The number felt was so large that no attempt was made to keep an accurate record of them. It may be assumed that all of the quakes from the Pahoa area which are listed below either were felt or could have been felt by favorably situated observers.

TABLE 8.-Number of earthquakes recorded per week, and weekly seismicity at the Hawaiian Volcano Observatory during 1955

[Based on the Bosch-Omori seismograph in the Whitney Laboratory of Seismology]

\begin{tabular}{|c|c|c|c|c|c|}
\hline Week beginning & $\begin{array}{l}\text { Number } \\
\text { of earth- } \\
\text { quakes }\end{array}$ & $\underset{\text { ity }^{1}}{\text { Seismic- }}$ & Week beginning & $\begin{array}{l}\text { Number } \\
\text { of earth- } \\
\text { quakes }\end{array}$ & Seismic- $_{\text {ity }}{ }^{1}$ \\
\hline 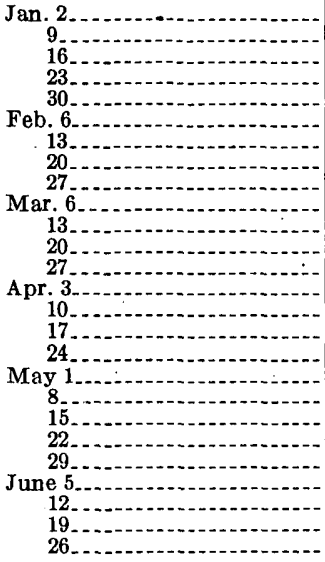 & $\begin{array}{r}19 \\
5 \\
44 \\
18 \\
17 \\
23 \\
20 \\
71 \\
131 \\
31 \\
92 \\
2,667 \pm \\
778 \pm \\
261 \\
201 \\
32 \\
8 \\
1 \\
9 \\
3 \\
10 \\
11 \\
2 \\
3 \\
1 \\
4\end{array}$ & $\begin{array}{l}8.5 \\
2.5 \\
27.25 \\
10.5 \\
6.25 \\
8.75 \\
6.5 \\
28.75 \\
41.0 \\
26.75 \\
53.5 \\
698.5 \pm \\
220.5 \pm \\
82.5 \\
56.0 \\
9.5 \\
7.25 \\
.5 \\
16.5 \\
3.25 \\
6.0 \\
15.0 \\
.75 \\
4.0 \\
.25 \\
1.5\end{array}$ & 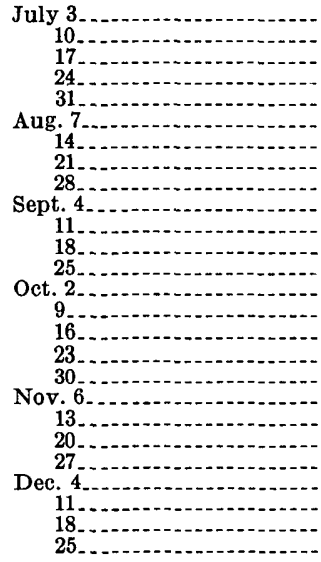 & $\begin{array}{r}5 \\
3 \\
3 \\
7 \\
7 \\
7 \\
7 \\
4 \\
2 \\
4 \\
3 \\
9 \\
11 \\
5 \\
25 \\
21 \\
21 \\
6 \\
4 \\
3 \\
3 \\
3 \\
5 \\
17 \\
0 \\
7\end{array}$ & $\begin{array}{l}2.5 \\
2.75 \\
2.75 \\
4.0 \\
2.75 \\
6.0 \\
6.5 \\
1.75 \\
.75 \\
1.5 \\
1.25 \\
5.0 \\
6.5 \\
1.75 \\
11.0 \\
6.75 \\
12.5 \\
3.5 \\
1.5 \\
2.75 \\
2.75 \\
1.0 \\
2.25 \\
5.25 \\
0.0 \\
5.5\end{array}$ \\
\hline
\end{tabular}

1 Local seismicity is an arbitrary value. Each local earthquake is assigned a seismicity value according to its strength, as follows: tremor, 0.25 ; very feeble, 0.5 ; feeble, 1.0 ; slight, 2.0 ; moderate, 3.0 ; strong, 4.0 . These values are totaled to give the weekly local seismicity. Continuous volcanic tremor is ignored in the calculation. The strength assigned to the earthquake depends on the double amplitude of the maximum oscillation it causes on the Bosch-Omori seismograph, as follows: tremor, less than $0.5 \mathrm{~mm}$; very feeble, 0.5 to $4 \mathrm{~mm}$; feeble, 4 to $11 \mathrm{~mm}$; slight, 11 to $25 \mathrm{~mm}$; moderate, 25 to $60 \mathrm{~mm}$; strong, greater than $60 \mathrm{~mm}$. 
TABLE 9.-Local earthquakes stronger than feeble recorded at the Hawaiian Volcano Observatory during 1955

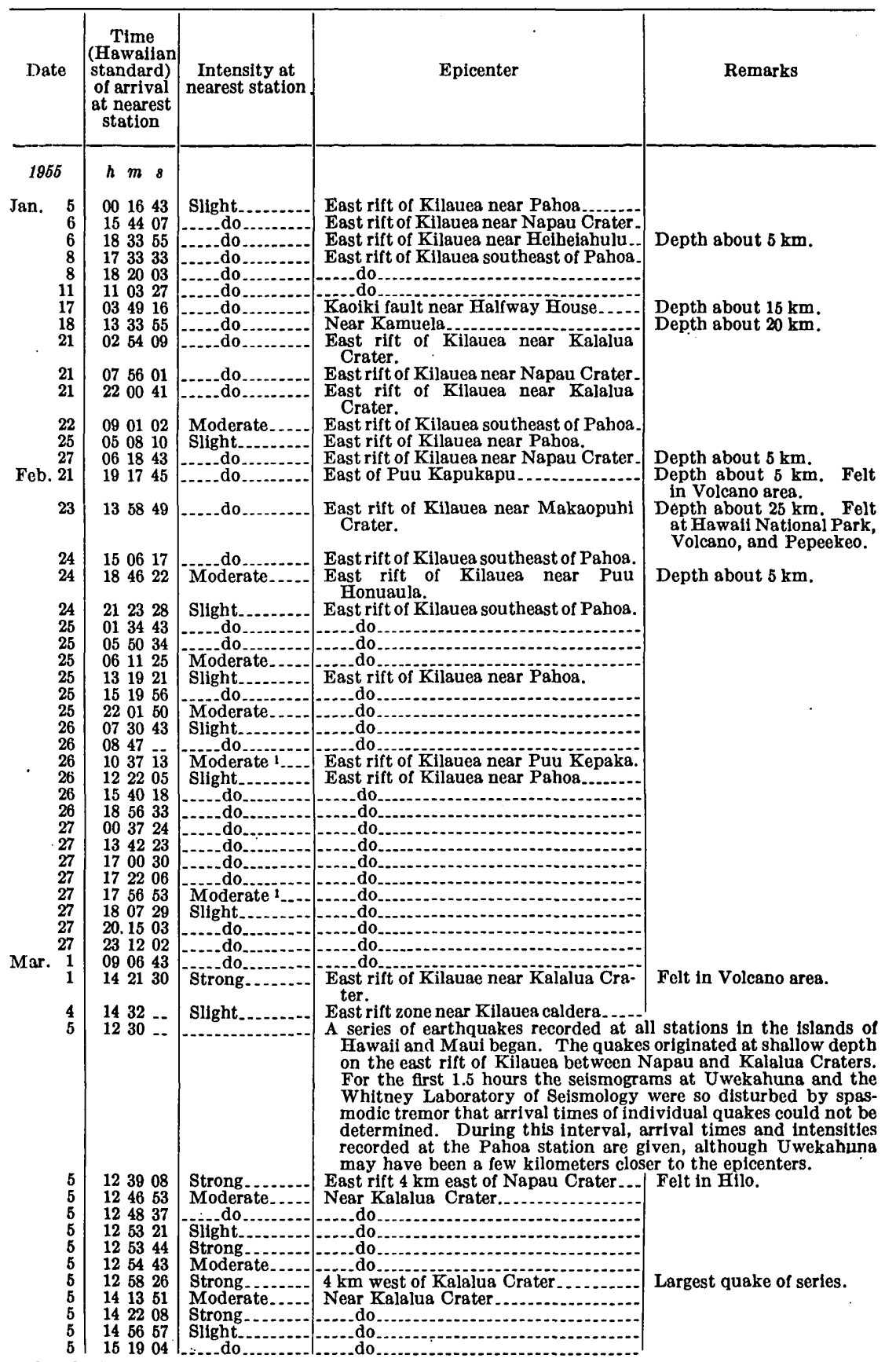

See footnotes at end of table. 
TABLE 9.-Local earthquakes stronger than feeble recorded at the Hawaiian Volcano observatory during 1955-Continued

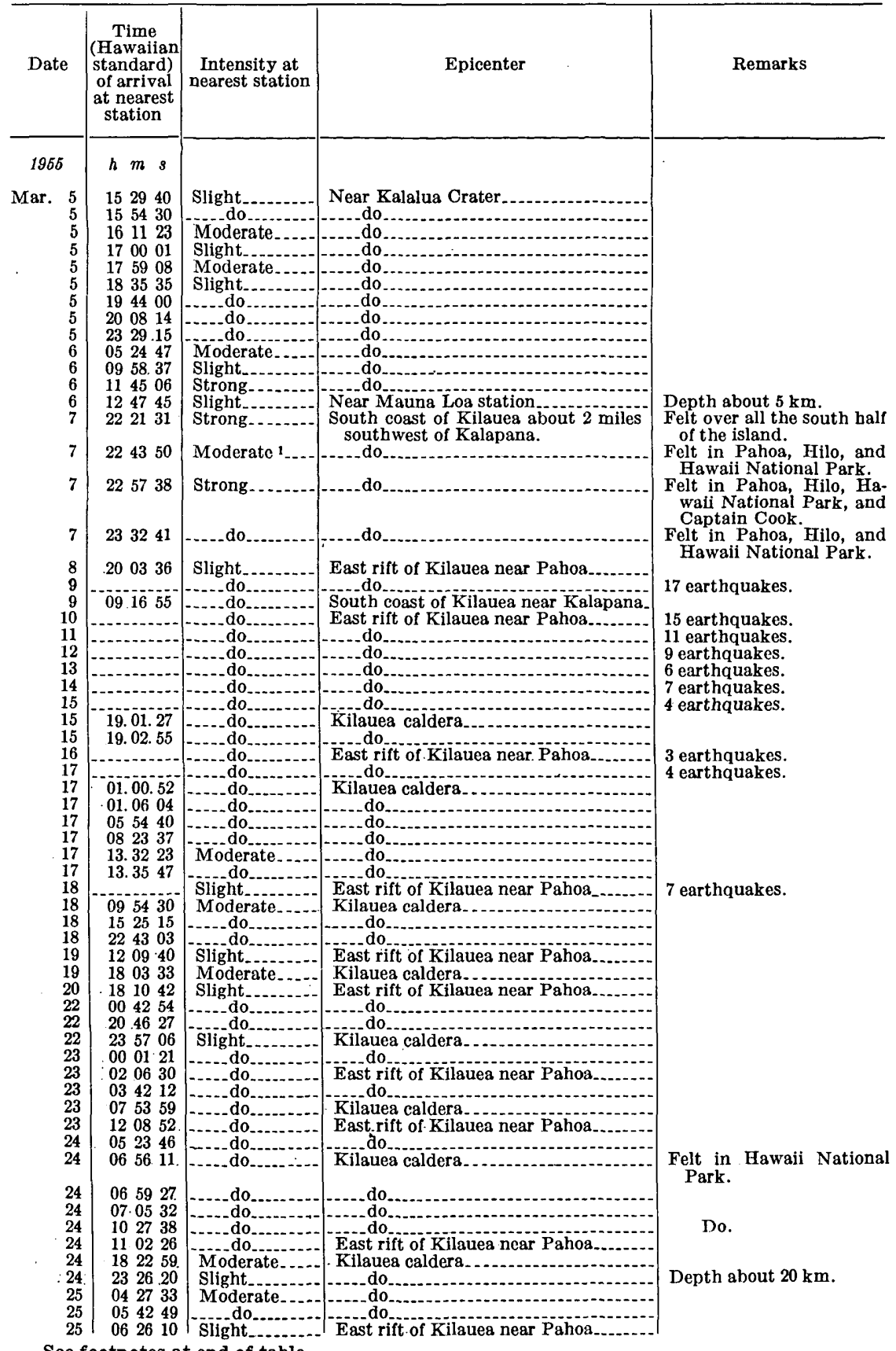

See footnotes at end of table. 
TABLE 9.-Local earthquakes stronger than feeble recorded at the Hawaiian Volcano Observatory during 1955-Continued

\begin{tabular}{|c|c|c|c|c|}
\hline Date & $\begin{array}{l}\text { Time } \\
\text { (Hawailian } \\
\text { standard) } \\
\text { of arrival } \\
\text { at nearest } \\
\text { station }\end{array}$ & $\begin{array}{c}\text { Intensity at } \\
\text { nearest station }\end{array}$ & Epicenter & Remarks \\
\hline 1956 & $h m s$ & & & \\
\hline $\begin{array}{r}\text { Mar. } 25 \\
25 \\
25 \\
25 \\
25 \\
25 \\
25\end{array}$ & $\begin{array}{lll}07 & 13 & 23 \\
07 & 34 & 28 \\
07 & 40 & 42 \\
07 & 41 & 24 \\
08 & 07 & 08 \\
08 & 54 & 49 \\
08 & 55 & 19\end{array}$ & 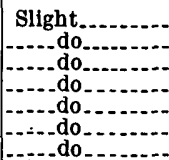 & $\begin{array}{l}\text { Kilauea caldera. } \\
\\
\text { do do } \\
\text { do } \\
\text { do }\end{array}$ & \\
\hline 25 & 201700 & Very feeble.... & About $10 \mathrm{~km}$ north of Kilauea caldera. & $\begin{array}{l}\text { Depth about } 40 \mathrm{~km} \text {. This } \\
\text { quake and the next are } \\
\text { representative of many } \\
\text { small quakes originating } \\
\text { in that region on March } \\
25,26 \text {, and } 27 \text {. } \\
\text { Depth about } 50 \mathrm{~km} \text {. }\end{array}$ \\
\hline $\begin{array}{l}27 \\
27\end{array}$ & $\begin{array}{lll}09 & 23 & 43 \\
16 & 02 & 20\end{array}$ & Strong & Kilauea caldera... & $\begin{array}{l}\text { Felt in Volcano area. } \\
\text { Felt strongly in Volcano } \\
\text { area. Waterlines broken } \\
\text { and roads cracked in } \\
\text { Hawail National Park. }\end{array}$ \\
\hline $\begin{array}{l}28 \\
30\end{array}$ & 203900 & Slight... & - do & \\
\hline & 134131 & Moderate & $\begin{array}{l}\text { Southwest rift of Mauna Loa } \\
15 \mathrm{~km} \text { northeast of Puu o K }\end{array}$ & \\
\hline Apr. $\begin{array}{r}30 \\
1\end{array}$ & $\begin{array}{lll}16 & 57 & 23 \\
04 & 24 & 28\end{array}$ & Strong & Kilauea caldera & \\
\hline & 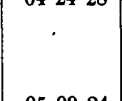 & Nowog- & sourawest rim or kilauea caldera & $\begin{array}{l}\text { generally over entire is- } \\
\text { land of Hawail and by a } \\
\text { few persons on Maul and } \\
\text { Oahu. }\end{array}$ \\
\hline 2 & 050924 & Slight... & Kilaues caldera......... & \\
\hline 4 & $\begin{array}{l}063756 \\
132844\end{array}$ & 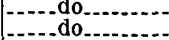 & do do & \\
\hline 4 & $13 \quad 34 \quad 14$ & ....do do & do & \\
\hline 6 & 143335 & Moderate & Near Kilauea caldera... & \\
\hline 6 & $\begin{array}{lll}15 & 59 & 34 \\
01 & 27 & 22\end{array}$ & slight.... & Near Hilina Pali. & Depth about $25 \mathrm{~km}$. \\
\hline$\stackrel{7}{9}$ & $\begin{array}{lll}15 & 48 & 54 \\
18 & 08 & 30\end{array}$ & Moderate. & Near Kilauea caldera. & \\
\hline 10 & 094502 & Feeble. - & $\begin{array}{l}\text { Southwest rift of Kilauea near Pono- } \\
\text { hohoa Chasms. }\end{array}$ & Depth about 15 km. \\
\hline $\begin{array}{l}12 \\
12\end{array}$ & $\begin{array}{lll}08 & 25 & 44 \\
12 & 49 & 56\end{array}$ & Moderate & East rim of Kilauea caldera...... & Felt in Volcano area. \\
\hline 22 & $\begin{array}{lll}05 & 47 & 16\end{array}$ & (ndon & East rift of Kilauea near Pahoa...... & \\
\hline 23 & 073351 & -....do..... & $\begin{array}{l}10 \mathrm{~km} \text { north of Halfway House and } \\
\text { west-north west of Volcano Observa- } \\
\text { tory. }\end{array}$ & $\begin{array}{l}\text { Depth about } 15 \mathrm{~km} \text {. Felt } \\
\text { in Hilo, Volcano area, } \\
\text { and Naalehu. }\end{array}$ \\
\hline $\begin{array}{l}24 \\
24\end{array}$ & 131908 & alla & Kilauea caldera & Felt in Volcano area. \\
\hline 24 & 090619 & Slight. & $\begin{array}{l}5 \mathrm{~km} \text { north of Halfway House and } 10 \\
\mathrm{~km} \text { west of Volcano Observatory. }\end{array}$ & Depth about $25 \mathrm{~km}$. Felt \\
\hline May 8 & 160157 & Moderate. & Near Puu Kapukapu. ..... & Felt at $\mathrm{Paboa}$ and Pepee- \\
\hline 9 & $\begin{array}{lll}05 & 44 & 51 \\
09 & 35 & 38\end{array}$ & Slight.. & East rim of Kilauea caldera. & $\begin{array}{l}\text { Felt in Volcano ares. } \\
\text { Do. }\end{array}$ \\
\hline 11 & 090653 & Moderat & Near Kilauea caldera........ & \\
\hline 12 & 103040 & Sligh & ....do............ & \\
\hline $\begin{array}{l}14 \\
15\end{array}$ & $\begin{array}{lll}10 & 34 & 23 \\
02 & 12 & 23\end{array}$ & Feeble... & Kilauea caldera & Depth about $40 \mathrm{~km}$. \\
\hline 16 & $\begin{array}{llll}23 & 26 & 17\end{array}$ & Slight.- & - do do & \\
\hline $\begin{array}{l}23 \\
29\end{array}$ & $\begin{array}{lll}01 & 40 & 47 \\
05 & 34 & 11\end{array}$ & Moderate......... & Near Kilauea caldera & \\
\hline June 1 & $\begin{array}{lll}01 & 59 & 50 \\
03 & 50 & 50\end{array}$ & 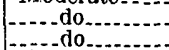 & East rim of Kilauea caldera. & \\
\hline 10 & 170211 & Very feeble. & Near Pahala & Depth about $75 \mathrm{~km}$. \\
\hline 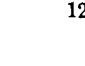 & 211556 & Slight.... & Near Mauna Loa seismograph station. & $\begin{array}{l}\text { Depth about } 15 \mathrm{~km} \text {. Felt } \\
\text { at Pahala, Naalehu, and } \\
\text { Volcano. }\end{array}$ \\
\hline 14 & 142935 & .....do_ & ............... & Depth about $15 \mathrm{~km}$. \\
\hline July 3 & $\begin{array}{lll}03 & 51 & 27 \\
10 & 4018\end{array}$ & (ndo... & $\begin{array}{l}\text { East rift of Kilauea near Pahoa } \\
\text { Kilauea caldera.......... }\end{array}$ & \\
\hline
\end{tabular}


TABLE 9.-Local earthquakes stronger than feeble recorded at the Hawaiian Volcano Observatory during 1955-Continued

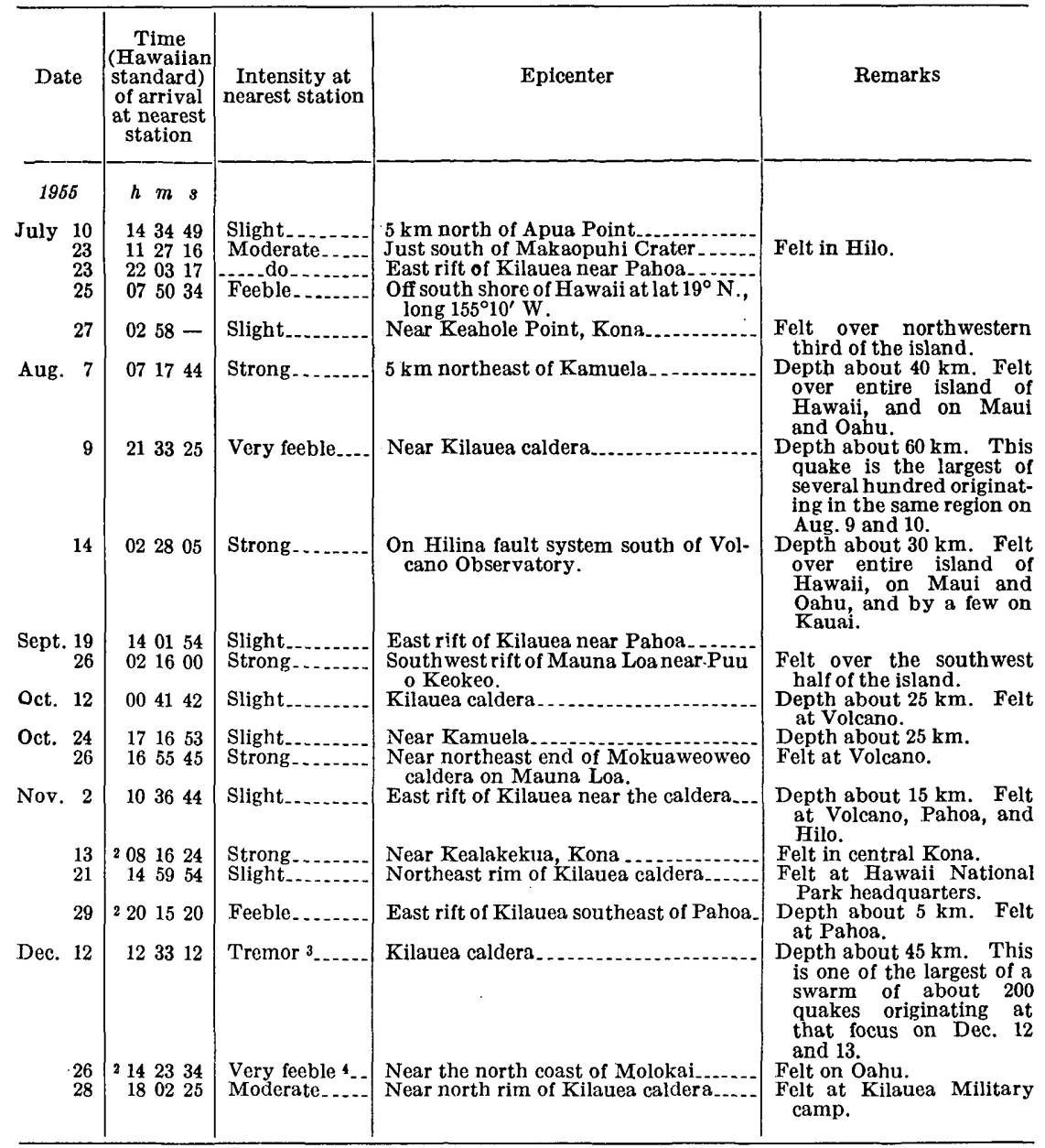

1 Intensity estimated; instrument at closest station dismantled.

2 Time of arrival at Uwekahuna.

3 Very feeble at Mauna Loa.

Intensity at Haleakala station.

\section{DISTANT EARTHQUAKES}

Table 10 lists earthquakes of distant origin recorded on the seismographs at the Hawaiian Volcano Observatory. Beginnings of phases are given in Greenwich civil time, which is 10 hours faster than $\mathrm{Ha}$ waiian standard time. Locations of epicenters, magnitudes, and depths of focus are from the notices of Preliminary Determinations of Epicenters published by the U.S. Coast and Geodetic Survey. 
TABLE 10.-Distant earthquakes recorded by seismographs of the Hawaiian Volcano Observatory during 1955

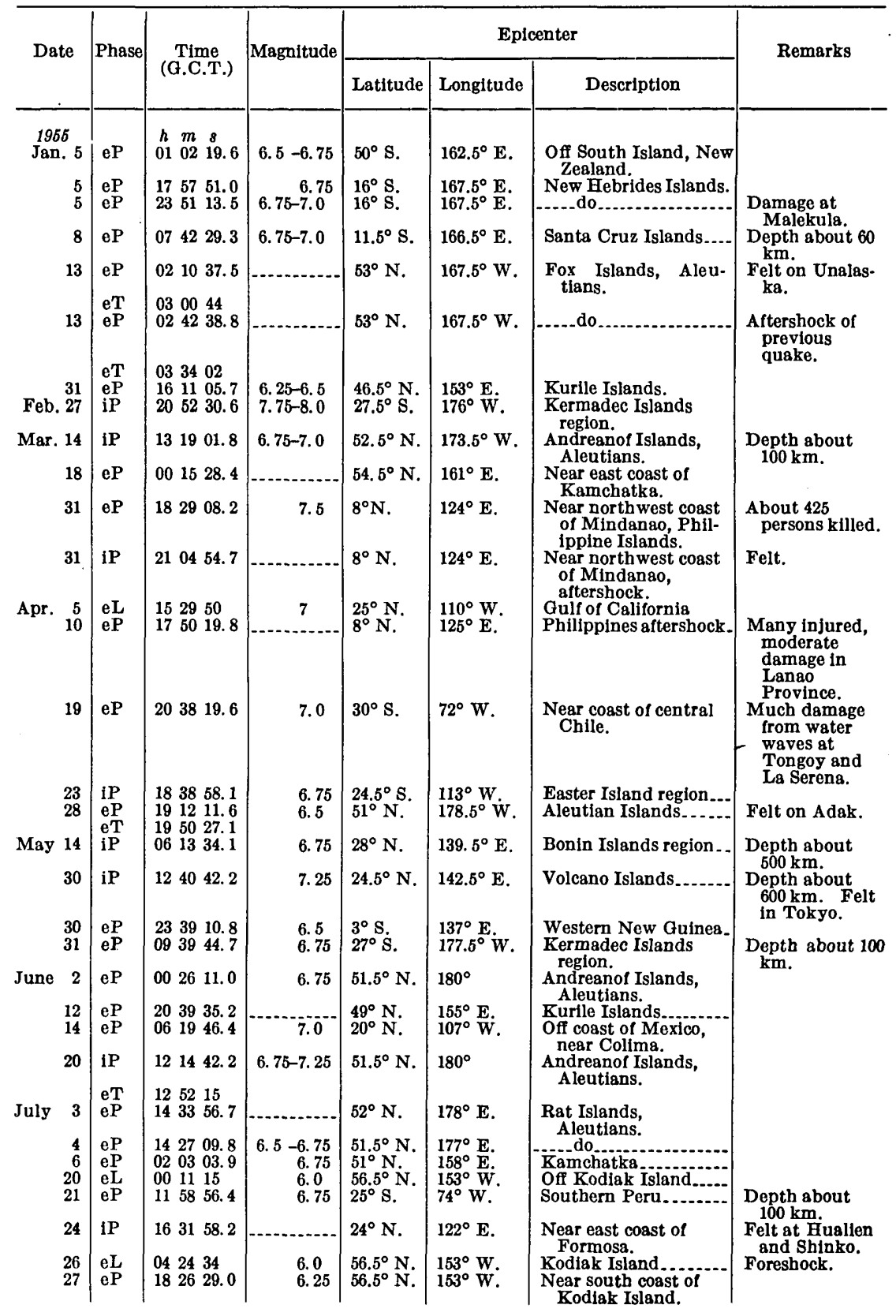


TABLE 10.-Distant earthquakes recorded by seismographs of the Hawoaian Volcano Observatory during 1955-Continued

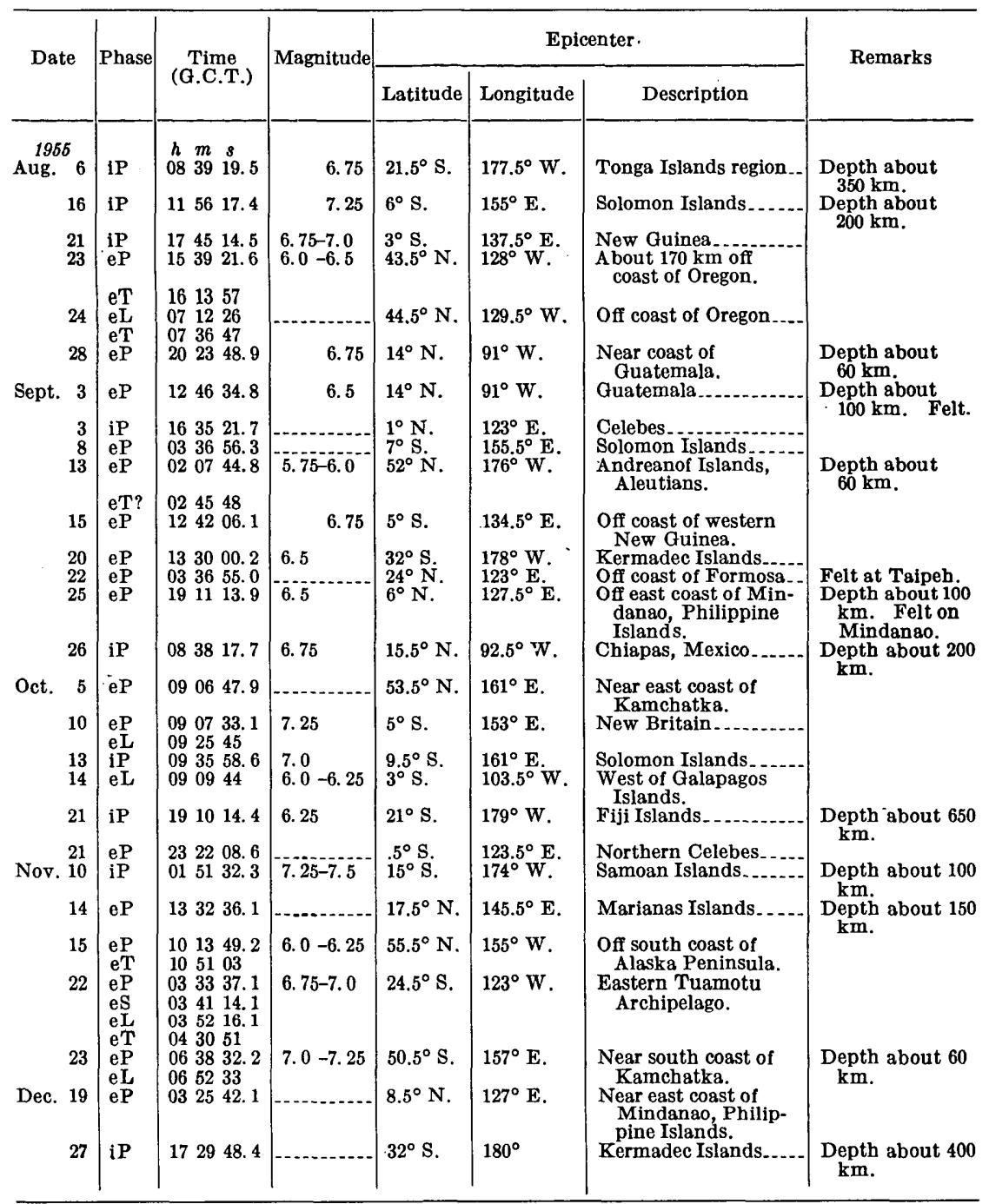




\section{TIITING OF THE GROUND}

Tiltmeters in use on the island of Hawaii are listed in table 7, and measurements obtained at the Whitney and Uwekahuna stations, on the northeast and west rims of Kilauea caldera respectively, are listed in table 11. Plates 4 and 5 show graphically the tilting of the ground at the same two stations. The rapid southwestward tilting at the Whitney Laboratory and southeastward tilting at Uwekahuna during March and early April indicate subsidence of the mountain summit accompanying the extrusion of lava in Puna, 20 miles to the east. The tilting is discussed further on a later page.

It is noteworthy that the subsidence of March and April, combined with the normal seasonal southwesterly tilt in May and June, brought the north-south tilt curve for the Whitney Laboratory to the lowest point in recent years, even lower than that reached in March and April 1951 (Macdonald and Wentworth, 1954, p. 159). The pressure that had been accumulating beneath the volcano since January 1953 (Macdonald and Eaton, 1955b, p. 143-144; 1957, p. 35-38, 55-56) had been completely relieved.

\section{CRACK MEASUREMENTS}

Measurements of crack widths were made throughout 1955 at 15 stations on the floor of Kilauea caldera and along the east rift zone 2 to 3 miles southeast of the caldera. (For locations of the measuring stations on the caldera floor see Macdonald and Eaton, 1955b, fig. 4.) The measurements are given in table 12.

Of the cracks around the rim of Halemaumau crater, only cracks 5 and 6 showed any appreciable change. These had been opening in 1954 and continued to open, though somewhat less rapidly, through 1955. They mark the south edge of a splinter of rock on the edge of the crater that has been collapsing piecemeal into the crater.

Cracks 37 and $37 \mathrm{~A}$ are the most active cracks on the floor of the caldera. Both closed rapidly between January 31 and June 4, during the period of subsidence of the mountaintop. Cracks 101A and 106, on the east rift zone respectively 2 and 3 miles southeast of the caldera (fig. 46), showed little change in width, suggesting that this part of the volcano was affected little or not at all by either the swelling that affected the rift zone in east Puna or the subsidence that occurred in the caldera area. 
TABLE 11.-Ground tilting at seismograph stations on the rim of Kilauea caldera during 1955

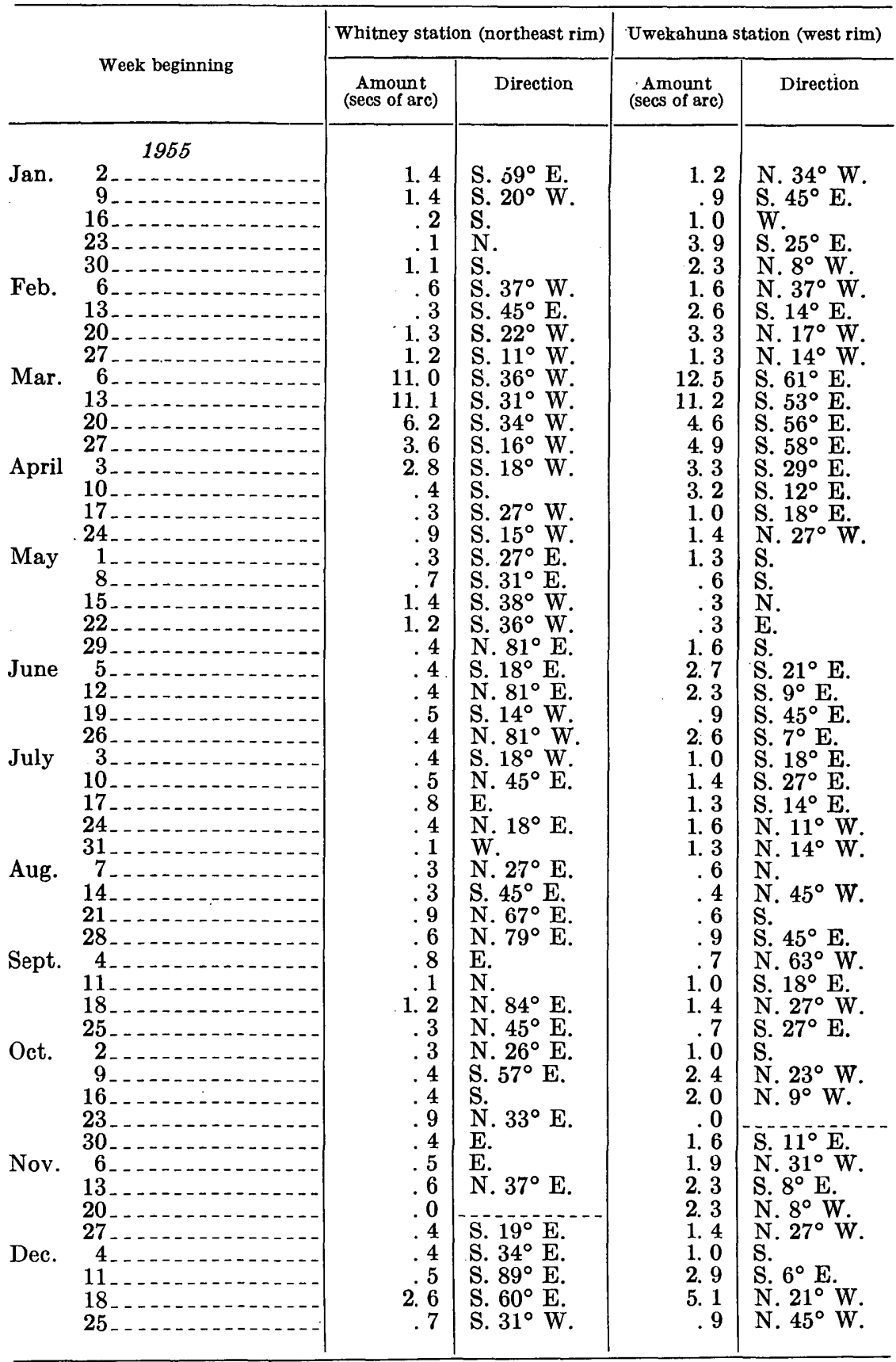




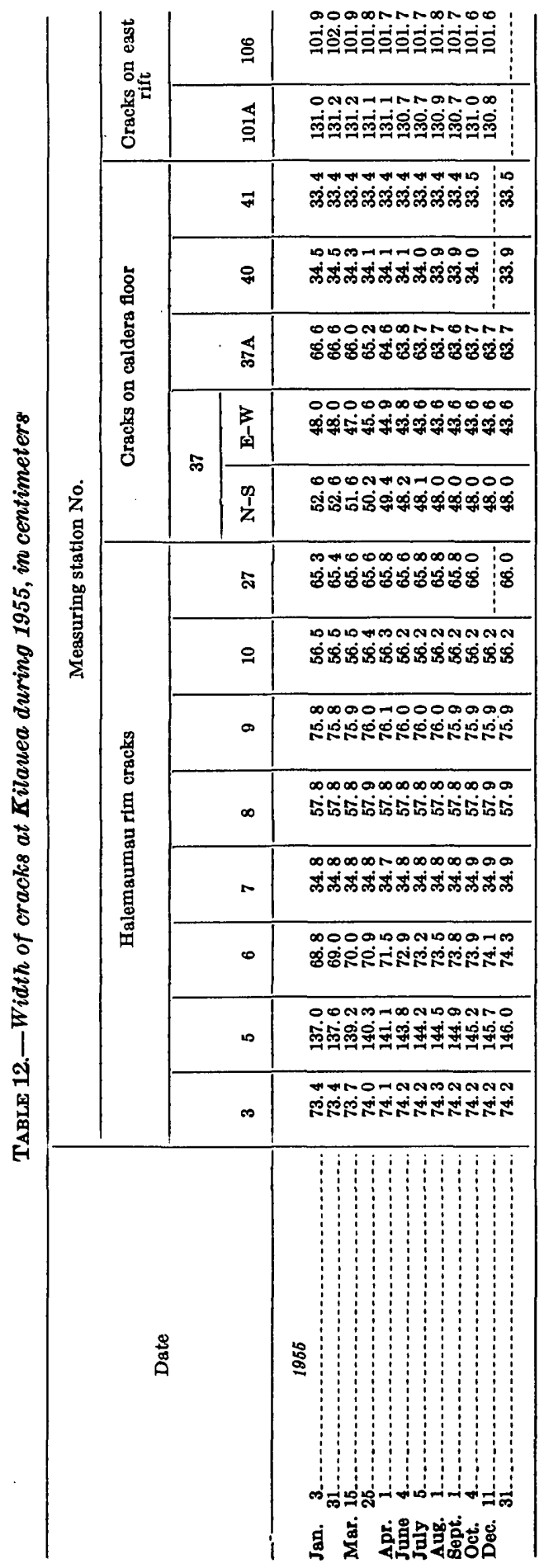




\section{TEMPERATURE MEASUREMENTS AT KILAUEA CALDERA}

Only three measurements of steam temperature were made at the drilled well at Sulphur Bank during the year. They were as follows:

January $15 \ldots$
February $14 \ldots$
November $23 \ldots$

Thus the reduction in temperature that occurred late in 1954 (Macdonald and Eaton, 1957, p. 40) continued into January 1955, but was followed by a rise of temperature later in the year. In late November, however, the temperature had not regained that of December 1954.

Measurements of lava temperatures made during the flank eruption in east Puna are given on a later page.

\section{CHEMICAL ANALYSES OF MAUNA LOA LAVAS}

Samples of the earliest and latest lava discharged during the 1949 eruption in Mokuaweoweo caldera were collected for chemical analysis. The piece representing the earliest lava was divided into three parts representing different textures: (a) the uppermost half an inch of glassy pumiceous crust, (b) a sample of less vesicular glass just below the pumice crust, and (c) a sample of partly crystalline and somewhat oxidized lava from 10 inches below the pumice crust. Columns 1 to 5 in table 13 give chemical analyses of the samples and an analysis of lava erupted during the middle of the eruption. The abundance of the trace elements in the earliest and latest lavas is given in table 14.

Very little difference exists between the compositions of the three samples of the earliest lava. That taken 10 inches below the pumice crust shows a somewhat higher state of oxidation of the iron, probably as the result of the action of gases rising from lower parts of the flow along the fissure on the edge of which the sample was collected. Also, there was little change in composition of the lava throughout the eruption. Except in the oxidation of the iron in the lowest sample (column 3), the analyses of the earliest lava differ little from those of the later lavas in columns 4 and 5. Similarly, little change occurred during the 1942 eruption (Macdonald, 1949a, p. 1572, columns 4 and 5 ).

In columns 6 to 9 of table 13 are given reanalyses of four prehistoric lavas of Mauna Loa. The original analyses were given by Stearns and Clark (1930, p. 163, columns 1 to 4) and were quoted by Macdonald (1949b, p. 63, columns 1 to 4). A careful study of the mineral content of the rocks led H. A. Powers to suspect that the original analyses contained inaccuracies, particularly in the alumina content. His suspicion was borne out by the new analyses. 
TABLE 13.-Chemical analyses of lavas of Mauna Loa

[Analyst, L. N. Tarrant]

\begin{tabular}{|c|c|c|c|c|c|c|c|c|c|}
\hline & 1 & 2 & 3 & 4 & 5 & 6 & 7 & 8 & 9 \\
\hline 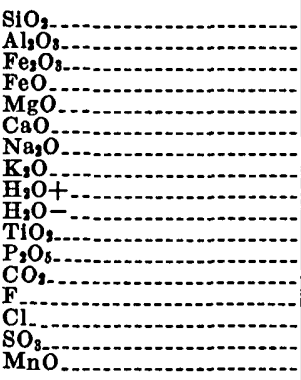 & $\begin{array}{r}52.15 \\
14.05 \\
1.67 \\
9.39 \\
7.05 \\
10.53 \\
2.27 \\
.38 \\
.01 \\
.02 \\
2.06 \\
.22 \\
.00 \\
.02 \\
.02 \\
.17\end{array}$ & $\begin{array}{r}62.17 \\
14.04 \\
1.99 \\
9.10 \\
7.09 \\
10.53 \\
2.25 \\
.41 \\
.00 \\
.01 \\
2.07 \\
.22 \\
.00 \\
.02 \\
-2 \\
.17 \\
.17\end{array}$ & $\begin{array}{r}51.05 \\
13.99 \\
5.77 \\
5.66 \\
7.06 \\
10.55 \\
2.27 \\
.37 \\
.00 \\
.01 \\
2.08 \\
.22 \\
.00 \\
.02 \\
.-. \\
.17\end{array}$ & $\begin{array}{r}52.04 \\
13.94 \\
1.58 \\
9.69 \\
7.14 \\
10.63 \\
2.25 \\
.33 \\
01 \\
.02 \\
2.05 \\
.26 \\
.00 \\
.00 \\
.01 \\
.18\end{array}$ & \begin{tabular}{r}
52.16 \\
14.13 \\
1.12 \\
9.90 \\
7.07 \\
10.53 \\
2.27 \\
.40 \\
.02 \\
.00 \\
2.04 \\
.21 \\
.00 \\
.02 \\
\hdashline .02 \\
.17
\end{tabular} & $\begin{array}{r}49.47 \\
14.58 \\
3.97 \\
8.10 \\
7.33 \\
9.33 \\
1.70 \\
.21 \\
1.78 \\
.87 \\
2.27 \\
.16 \\
.02 \\
.02 \\
-2 \\
.18\end{array}$ & $\begin{array}{r}48.40 \\
14.33 \\
2.42 \\
9.18 \\
9.78 \\
10.17 \\
2.31 \\
.27 \\
.20 \\
.07 \\
2.52 \\
.22 \\
.02 \\
.02 \\
.16\end{array}$ & $\begin{array}{r}48.71 \\
15.07 \\
4.11 \\
8.55 \\
6.04 \\
10.19 \\
-2.43 \\
.36 \\
.84 \\
.39 \\
2.78 \\
.28 \\
.02 \\
.02 \\
.18\end{array}$ & $\begin{array}{r}46.19 \\
7.94 \\
6.11 \\
6.52 \\
24.20 \\
5.76 \\
1.23 \\
.28 \\
.14 \\
.05 \\
1.24 \\
.15 \\
.01\end{array}$ \\
\hline Total & 99.99 & 100.07 & 100.12 & 100.13 & 100.04 & 99.97 & 100.05 & 99.95 & 89.89 \\
\hline
\end{tabular}

1. Earliest lava of 1949 eruption, pumice from top half an inch of flow just nor thwest of the 1940 cone, Mokuaweoweo caldera.

2. Earliest lava of 1949 eruption, dense glassy phase of flow just below the upper 1/2-Inch layer of pumice same locality as 1 .

3. Earliest lava of 1949 eruption, oxdized partly crystalline phase, 10 inches below the upper pumice layer, same locality as 1.

4. Lava of 1949 eruption, extruded about 3 weeks after the beginning of the eruption; 100 feet southwest of the southwest edge of South Pit, just southwest of Mokuaweoweo.

5. Last lava of 1949 eruption; dense glassy spatter on the flanks of the 1949 spatter cone at southwest end of Mokuaweoweo caldera.

6. Basait, Ninole volcanic series, Clover Hill, 0.9 mile northwest of Naalehu, south side of Mauna Los. (For original analysis see Stearns and Clark, 1930, p. 163, column 1.)

7. Olivine basalt, Ninole volcanic series, Kaumaikeohu Spring, south side of Mauns Loa. (For original analysis see Stearns and Clark, 1930, p. 163, column 2.)

8. Basalt, prehistoric flow of Kau volcanic series, south side of Mauna Loa 0.7 mile north of Naalehu. (For original analysis see Stearns and Clark, 1930, p. 163, column 3.)

9. Picrite-basalt of oceanite type, prehistoric flow of Kau volcanic series, Makanao Valley, 1.5 miles northwest of Hilea, south slope of Mauna Loa. (For original analysis see Stearns and Clark, 1930, p. 163, column 4.)

TABLE 14.-Abundance of trace elements (in percent) in lavas of the 1949 eruption of Mauna Loa

[Spectrographic analyst, P. R. Barnett]

\begin{tabular}{|c|c|c|c|c|c|}
\hline & 1 & 2 & & 1 & 2 \\
\hline 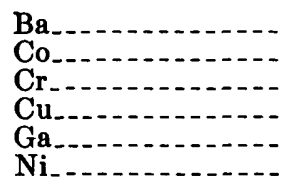 & $\begin{array}{l}0.008 \\
.004 \\
.02 \\
.03 \\
.001 \\
.01\end{array}$ & $\begin{array}{l}0.008 \\
.004 \\
.02 \\
.03 \\
.001 \\
.01\end{array}$ & 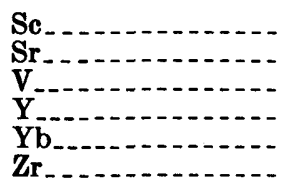 & $\begin{array}{l}0.002 \\
.05 \\
.03 \\
.006 \\
.0002 \\
.02\end{array}$ & $\begin{array}{l}0.002 \\
.05 \\
.03 \\
.006 \\
.0002 \\
.02\end{array}$ \\
\hline
\end{tabular}

Looked for but not found: Ag; As, Au, B, Be, Bi, Cd, Ge, In, La, Mo, Nb, Pb, Pt, Sb, Sn, Ta, Th, Tl, U,

W. Earliest lava of 1949 eruption, just northwest of the 1940 cone, Mokusweoweo caldera.

2. Latest lava of the 1949 eruption, spatter on the flanks of the 1949 spatter cone at the southwest end of Mokuaweoweo caldera.

$690-0000-64-11$ 


\section{RAINFAII, RECORDS}

Daily readings of rainfall were continued at the gage near the Uwekahuna seismograph station throughout 1955 . Gages at the Mauna Loa seismograph station and 5,500 feet altitude on the Mauna Loa truck trail were read every 2 days. A rain gage 300 feet north of the southeast tilt cellar, on the floor of Kilauea caldera southeast of Halemaumau, was read once a month. The monthly totals for these gages are given in table 15 .

TABLE 15.-Rainfall during 1955, in inches

\begin{tabular}{|c|c|c|c|c|}
\hline Month & Halemaumau & $\begin{array}{l}\text { Uwekahuna } \\
\text { seismograph } \\
\text { station }\end{array}$ & $\begin{array}{l}\text { Mauna Loa } \\
\text { truck trail } \\
\text { (5,500 feet } \\
\text { altitude) }\end{array}$ & $\begin{array}{l}\text { Mauna Loa } \\
\text { seismograph } \\
\text { station }\end{array}$ \\
\hline $\begin{array}{l}\text { January } 1955 \\
\text { February } \\
\text { March } \\
\text { April } \\
\text { May } \\
\text { June } \\
\text { July } \\
\text { August } \\
\text { September } \\
\text { October } \\
\text { November } \\
\text { December }\end{array}$ & $\begin{array}{r}2.85 \\
14.45 \\
6.16 \\
5.76 \\
.86 \\
.17 \\
.71 \\
1.15 \\
1.50 \\
.92 \\
6.50 \\
8.58\end{array}$ & $\begin{array}{r}\text { 6. } 92 \\
\text { 15. } 40 \\
6.67 \\
7.38 \\
2.17 \\
.21 \\
.82 \\
1.83 \\
1.83 \\
3.08 \\
7.47 \\
11.90\end{array}$ & $\begin{array}{r}\text { 8. } 02 \\
\text { 10. } 98 \\
5.32 \\
2.61 \\
1.88 \\
.21 \\
1.98 \\
2.44 \\
2.32 \\
2.13 \\
4.61 \\
7.26\end{array}$ & $\begin{array}{r}9.23 \\
12.57 \\
4.31 \\
3.88 \\
2.91 \\
.22 \\
1.81 \\
3.28 \\
2.57 \\
2.48 \\
5.02 \\
8.02\end{array}$ \\
\hline Total & 49. 61 & 65. 68 & 49. 76 & 56. 30 \\
\hline
\end{tabular}

\section{AGES OF SOME PREHISTORIC LAVAS}

During the 1955 eruption of Kilauea, State Senator Richard Lyman found a specimen of charcoal in a tree mold in a prehistoric flow of pahoehoe in east Puma, 0.85 mile N. $36^{\circ} \mathrm{W}$. of the point on the coast where the Keekee lava flow of 1955 entered the ocean (pl. 1.) The site was later covered by the edge of the Keekee flow. The mold was about 4 inches in diameter, nearly horizontal, and had formed around what was probably a small trunk of an ohia tree (Metrosideris sp.) that had been knocked over by the flow and engulfed in the lava. A carbon-14 analysis by the U.S. Geological Survey (Rubin and Alexander, 1958, sample 359; and written communication, 1961) indicates an age for the charcoal of not more than 400 years, allowing for possible inaccuracies resulting from variations in the $\mathrm{C}^{14}$ content of the air during the past 3,000 years. This helps confirm the belief based on other evidence that most of east Puna has been inundated by lava flows during the last few hundred years. 
During the autumn of 1955 Stephen Ho, of Hilo, reported the discovery of charcoal in his cinder quarry in the upper part of the Waiakea Homesteads. The locality is at the northwest edge of a kipuka of lavas of the Kahuku volcanic series capped with a layer of Pahala ash (Stearns and Macdonald, 1946, pl. 1), 5.5 miles S. $33^{\circ} \mathrm{W}$. of the southwest shore of Hilo Bay (fig. 1). Just northwest of the kipuka is a line of small cinder-and-spatter cones alined east-northeast parallel to the northeast rift zone of Mauna Loa and almost completely buried by later lava flows. The cones were exposed by $\mathbf{M r}$. Ho while clearing land by bulldozer and were later opened up as a cinder quarry. The cones and later flows belong to the Kau volcanic series (Stearns and Macdonald, 1946, p. 76-80), the youngest group of lavas of Mauna Loa. The charcoal occurs in the cinder and spatter resting on the Pahala ash, and its age thus represents that of the oldest lavas of the Kau volcanic series at that locality.

Radiocarbon age determinations were made by the Geological Survey on two samples supplied by Mr. Ho (Rubin and Alexander, 1958). One sample, a specimen of dense wood (sample W-477), probably ohia (Metrosideris sp.), gave an age of 2,000 \pm 250 years, and the other (sample W-478), a specimen of tree fern (Cibotium sp.), 2,070 \pm 250 years. Thus the two samples are in general agreement. The age of the charcoal and enclosing cinder probably is not less than 1,750 years. An age of a few thousand years is consistent with the general appearance of the lavas of the region, which in spite of a heavy vegetative cover are largely unweathered and uneroded. It helps confirm the belief that the lavas of the Kau volcanic series, which form most of the surface in the Hilo area and have built the broad peninsula east of Hilo Bay have all been erupted during the last few thousand years (Macdonald, 1958, p. 261). The vent at the Ho quarry is the only known vent of the Kau volcanic series east of Puu Kipu, which lies 15 miles farther west-southwest at 6,250 feet altitude on the northeast rift zone of Mauna Loa (Stearns and Macdonald, 1946, pl. 1).

\section{VOLCANIC CONDITIONS AND EARTHQUAKES}

January.-Marked seismic unrest at Kilauea volcano through most of January. The Bosch-Omori seismograph at the Whitney Laboratory of Seismology, on the northeast rim of Kilauea caldera, recorded 94 earthquakes during the month. This is nearly the same number as recorded in December 1954, and between two and three times the number normally recorded during times of volcanic quiet. The local seismicity was more than four times as great as that normally experienced during quiet periods. The more sensitive Sprengnether 
seismograph at the Uwekahuna station recorded 316 earthquakes during January, a few less than during December. Most of the quakes originated in or very close to the Kilauea caldera region, probably on the east rift zone or the zone of faults that extends westward from it 2 to 4 miles south of the caldera.

Even greater seismic activity was displayed at the Pahoa station, where 140 quakes were recorded on the Loucks-Omori seismograph as compared to 127 during December. Most of the quakes originated on the east rift zone of Kilauea within 6 miles of the station.

Tilting of the ground surface at the northeast rim of Kilauea caldera was south-southwestward at a rate normal for that season of the year.

February.-Seismic activity along the east rift zone of Kilauea volcano increased throughout February. From February 1 to 23, the Pahoa seismograph recorded an average of 6 earthquakes a day, excluding swarms on February 12 and 17. On February 12 a swarm of 50 small quakes was recorded, and on the 17th a swarm of 173 . On February 24 the instrument recorded 130 quakes. On subsequent days the number increased rapidly to 350 on the 25 th, 600 on the $26 \mathrm{th}$, and 700 on the 27 th. The last three numbers are estimates because the seismograph was dismantled for several short periods. Most of the earthquakes originated within 10 miles of the station.

The seismic activity along the east rift zone began in November, 1954 and continued with general slight increase through December, January, and February. It was accompanied by similar activity in the caldera region. This growing unrest within the volcano was pointed out in press releases in November, December, January, and early February, and in Volcano Letter 526 (Macdonald and Eaton, 1954). It was culminated at $8^{\mathrm{h}}$ on February 28 by eruption of the volcano on the east rift near the southern base of Puu Honuaula, 6 miles west-southwest of Cape Kumukahi (East Cape). . The eruption is described in detail in another section.

Throughout most of February tilting of the ground surface at the northeast rim of Kilauea caldera was south-southwestward at a rate approximately normal for that season of the year. Beginning about February 20, however, the rate of southwestward tilting increased markedly, indicating a decrease of volcanic pressure beneath the caldera region.

Mauna Loa showed no sign of unrest in sympathy with that at Kilauea.

March-May.-The major volcanic events of March, April, and May were the eruption on the east rift zone of Kilauea, in east Puna, and the sinking of the summit area of Kilauea. 
Over the rest of the island seismic activity was low during the 3-month period. Mauna Loa continued to show no sign of uneasiness.

During May seismic activity became low in east Puna and the Kilauea caldera area also. The Pahoa seismograph recorded only 25 earthquakes during the month, and only 35 were recorded at the Whitney Laboratory, on the northeast rim of the caldera. The Mauna Loa seismograph recorded 56 earthquakes, indicating a minor increase of seismic activity on the east rift zone of Mauna Loa.

June.-There was little volcanic or seismic activity during this month. Quiet release of volcanic fume and steam continued at the vents of the recent eruption in east Puna, and blue flames were occasionally visible where the rift zone crosses the old Kalapana road. The amount of visible steam varied greatly, probably in large part because of variations in the amount of rainfall and temperature and humidity of the atmosphere.

The Bosch-Omori seismograph in the Whitney Laboratory of Seismology recorded only 18 earthquakes during June. This was the smallest number recorded since February 1953. The Phaoa seismograph recorded 28 quakes, 3 more than in May. The Mauna Loa seismograph recorded 52 quakes, 4 less than in May. Some of these originated at Kilauea, others on the Kaoiki fault zone between Kilauea and Mauna Loa, and others on Mauna Loa, probably on the east rift zone. No harmonic tremor was recorded on any of the seismographs.

A sharp earthquake felt from Naalehu to the Volcano district at $21^{\mathrm{h}} 16^{\mathrm{m}}$ on June 12 probably originated on the Kaoiki fault. A quake of local origin rattled windows in the Waimea area at $7^{\mathrm{b}} 11^{\mathrm{m}}$ on June 29.

$J u l y$.-No notable seismic or volcanic activity occurred during this month. The seismograph in the Whitney Laboratory of Seismology recorded only 21 earthquakes, most of them very small. The Mauna Loa seismograph recorded 40 small quakes during the month, 12 less than during June.

The seismograph at Pahoa School recorded 29 earthquakes during July, as compared with 28 during June. Most of the quakes were small and probably originated along the part of the east rift zone of Kilauea volcano affected by the recent eruption. At $22^{\mathrm{h}} 23^{\mathrm{m}}$ on July 23 a quake felt strongly on the rift zone at the Pahoa-Kalapana road was felt only weakly in Pahoa and Kaueleau. It originated at a very shallow focus near Iilewa Crater.

The ground surface at the northeast rim of Kilauea caldera tilted slightly eastward during the month. Normally during this season of the year the tilting is northeastward. The absence of northward 
tilting probably indicates a slight continuation of the decrease of volcanic pressure beneath the caldera that was conspicuous during the eruption in east Puna, and continued at a reduced rate during late May and June.

Volcanic activity at the surface was confined to mild steaming and fuming at the vents of the recent eruption in east Puna and at the steam vents and solfataras normally active in the caldera region. On several days steam release was strong at the old Kalapana road and at the vents southwest of Puu Kii. However, this appeared to result from heavy rains. At one vent the sound of steam bubbling through accumulated rainwater could be heard. Gas flames no longer were observed along the Kalapana road.

Except for the occasional periods of voluminous steaming resulting from heavy rains, there appears to have been a gradual, slight but definite decrease in temperature and fume release at the east Puna vents during June and July. That, together with the low level of seismic activity, appeared to indicate that the east Puna eruption was over.

August-Hawaiian volcanoes remained fairly quiet throughout the month of August, although two deep earthquakes were felt lightly over a large part of the island group. The seismograph in the Whitney Laboratory of Seismology recorded only 23 earthquakes, 2 more than during the month of July. The seismograph at Pahoa School recorded 39 quakes, 10 more than during July.

Most of the seismic activity was recorded at the Mauna Loa station. Throughout most of the month activity at that station also was small, but between $11^{\mathrm{h}}$ on August 9 and $24^{\mathrm{b}}$ on August 10 more than 600 very small earthquakes were recorded. These quakes appear to have originated beneath Kilauea caldera at a depth of about $60 \mathrm{~km}$.

At $7^{\mathrm{h}} 18^{\mathrm{m}}$ on August 7 an earthquake was felt generally on the islands of Hawaii and Maui, and by many people on Oahu. It originated at a depth of about 25 miles beneath the Waimea area on the island of Hawaii. Another quake, felt to about the same degree over the same area at $2^{\mathrm{b}} 28^{\mathrm{m}}$ on August 14, originated at a depth of about 20 miles beneath the Hilina Pali area, on the south slope of Kilauea volcano. A slight earthquake was felt at $5^{h 2} 7^{m}$, August 19 , in the volcano area. On August 29, at $2^{h} 41^{m}$ and $2^{h} 44^{m}$ slight quakes were felt at Nanawale Ranch, 3 miles east of Pahoa. They had their origin on the east rift zone of Kilauea.

Tilting of the ground surface at the northeast edge of Kilauea caldera was eastward, rather than in the usual north-northeastward direction. This probably indicated a decrease of pressure beneath 
the volcanic structure to the south and southeast of the Whitney Laboratory.

Liberation of steam and sulfurous fume continued weak to moderate along the vent fissures of the eruption in east Puna. There was no sign of any resumption of volcanic activity in east Puna or elsewhere.

September.-Hawaiian volcanoes remained quiet during the month of September. The Bosch-Omori seismograph in the Whitney Laboratory of Seismology recorded only 22 earthquakes. This was one less than during August and one more than during July. The more sensitive Sprengnether vertical seismograph at the Uwekahuna station recorded 164 quakes during the month. The Mauna Loa seismograph recorded 47, and the seismograph at Pahoa School recorded 38 quakes.

At $2^{h} 16^{\mathrm{m}}$ on : September 26 an earthquake was felt strongly at the Kapapala Ranch and weakly. all over the southern part of the island, from Kalapana to south Kona. It originated on the southwest rift zone of Mauna Loa 2 or 3 miles south of Puu o Keokeo. No damage was reported.

Eastward tilting of the ground surface at the northeast rim of Kilauea caldera was approximately normal, but northward tilting was much less than usual during that season of the year. This appears to represent a small reduction in volcano pressure beneath Kilauea and adjacent parts of the east rift zone.

October.-During the month of October earthquake activity on the island of Hawaii increased somewhat over that of preceding months. The Bosch-Omori seismograph at the Whitney Laboratory of Seismology recorded 79 earthquakes, as compared.with 22 during the month of September. The more sensitive Sprengnether vertical seismograph at Uwekahuna recorded 327 quakes.

Most of the earthquakes originated at or near Kilauea caldera and probably were related to the slight sinking of the caldera region (indicated by tilting of the ground surface) that had continued ever since the end of the Puna eruption in late May. The quake felt in the Volcano district at $0^{\mathrm{h}} 42^{\mathrm{m}}$ on October 12 came from a depth of about 15 miles beneath Kilauea caldera. Another, felt in Hilo at $22^{\mathrm{h}} 07^{\mathrm{m}}$ on October 29 , probably came from the same region. A quake felt in the Volcano district and at Pahala at $16^{\mathrm{h}} 33^{\mathrm{m}}$ on October 24 originated near the mouth of Wood Valley, probably on the Kaoiki fault zone. Earthquakes felt at Kamuela and Umikoa at $17^{\mathrm{h}} 17^{\mathrm{m}}$ and $23^{\mathrm{h}} 45^{\mathrm{m}}$ on October 24 came from a depth of about 18 miles beneath the Waimea region. 
The strongest earthquake of the month occurred at $16^{\mathrm{h}} 56^{\mathrm{m}}$ on October 26 and originated near the summit of Mauna Loa. Several smaller quakes also came from Mauna Loa. Eastward tilting of the ground surface at the edge of Kilauea caldera, accompanied by less than normal northward tilting, may have indicated a small increase of volcanic pressure beneath Mauna Loa.

A series of landslides on the southwest wall of Halemaumau crater began in late September and continued into October. A large segment of the crater rim, estimated to be 100 feet long, 75 feet high, and 5 to 10 feet thick, fell into the crater during the night of October 1 . The last large slide occurred on October 10, but occasional small slides continued throughout the rest of the month.

November.-The Hawaiian volcanoes were very quiet through the month of November. The Bosch-Omori seismograph in the Whitney Laboratory recorded only 19 earthquakes during the month, the smallest number since February, 1953. The Sprengnether vertical seismograph at Uwekahuna recorded 100 quakes during November. The Loucks-Omori seismograph in the Mauna Loa station recorded 47 quakes, most of them very small.

An earthquake at $10^{\mathrm{h}} 37^{\mathrm{m}}$ on November 2 was reported felt at Hilo, Pahoa, and in the Volcano district. It originated at a depth of about 10 miles on the east rift zone of Kilauea, near the caldera. On November 3 and 4 several tiny quakes felt in Naalehu originated very close to that town. A quake felt in central Kona at $8^{\mathrm{h}} 16^{\mathrm{m}}$ on November 13 originated near Kealakekua, probably on the Kealakekua fault. At $15^{\mathrm{h}}$ on November 21 a sharp earthquake was felt only in the Headquarters area of Hawaii National Park. It originated beneath the northeast edge of Kilauea caldera.

The Pahoa seismograph recorded 17 earthquakes during November. One of these, at $20^{\mathrm{h}} 15^{\mathrm{m}}$ on November 29 , was felt at Pahoa School. It originated at a depth of about 3 miles on the east rift zone of Kilauea southeast of Pahoa. Steam and sulfur gas continued to escape from the vents of the 1955 eruption, particularly those at the old Kalapana road, those south-southeast of Iilewa Crater, and those south of the Kapoho road. There had been no noticeable change in the temperature of the escaping steam since shortly after the end of the eruption. Several places in the last flows southwest of the Kamaili-Opihikao road remained very hot. At one of them the temperature was still about $870^{\circ} \mathrm{F}$. There were no signs whatever of any renewal of volcanic activity in Puna.

Tilting of the ground surface at the Whitney Laboratory was almost due eastward throughout the month. Normally at that season of the year the tilting is north-northeastward. The absence of northward 
tilting during November appeared still to be the result of slow sinking of the top of Kilauea volcano south of the Whitney Laboratory that had continued ever since the end of the Puna eruption. The sinking is believed to have been caused by a small reduction in volcanic pressure beneath the volcano. The eastward tilting, combined with an absence of northward tilting, may have indicated a slight swelling of Mauna Loa volcano, but the evidence was inconclusive.

December.--Except for the continued liberation of steam along the vents of the 1955 eruption, Hawaiian volcanoes remained quiet during December.

Twenty-nine earthquakes, about the average for months of volcanic quiet, were recorded during December at the Whitney Laboratory. Only 10 earthquakes from the Puna area were recorded at Pahoa during December.

On December 12 and 13 a swarm of tiny earthquakes originated about $45 \mathrm{~km}$ beneath Kilauea caldera. The Sprengnether vertical seismograph at Uwekahuna recorded about 200 earthquakes from that source on those 2 days. A total of 307 earthquakes, mostly very small, were registered on the Sprengnether seismograph during the month.

A small earthquake which probably originated in Hualalai volcano was felt at Honokohau at $15^{\mathrm{h}} 15^{\mathrm{m}}$ on December 7. The earthquake felt on the island of Oahu at $14^{\mathrm{h}} 23^{\mathrm{m}}$ on December 26 was recorded feebly on the Uwekahuna seismograph. At $14^{\mathrm{h}} 14^{\mathrm{m}}$ on December 28 an earthquake originating along the southwest rift of Kilauea was felt at the Kapapala Ranch. Later the same day, at $18^{\mathrm{h}} 02^{\mathrm{m}}$, an earthquake originating beneath the north rim of Kilauea caldera at a very shallow depth was felt at Kilauea Military Camp.

\section{POSSIBLE VOLCANIC ERUPTION NEAR NECKER ISLAND}

On August 20 the crew and passengers of a M.A.T.S. plane flying from Japan to Hawaii sighted an oval area of steaming, turbulent water about 1 mile across, between Necker and Nihoa Islands in the northern part of the Hawaiian Archipelago. The disturbance was first observed from a distance of several miles as a column of "smoke" rising from the water. The approximate position of the disturbance was $23^{\circ} 35^{\prime} \mathrm{N}$., $163^{\circ} 50^{\prime} \mathrm{W}$. The patch of turbulent water was surrounded by a thin line of yellowish surf, and near one end of the oval was what appeared to be an acre or two of dry land. Yellowish water drifted off down current. The next day all this had disappeared. Only a slick on the water surface marked the location of the previous day's activity, and a series of large waves swept outward from the area. 
The position lies on the north side of the submarine ridge whose summit is marked by the Leeward Islands of the Hawaiian group, but the depth of water indicated at that point by hydrographic charts of the U.S. Coast and Geodetic Survey is in excess of 2,000 fathoms.

The description is typical of submarine eruptions, and if it is accurate it is difficult to conceive what else could have been the cause of the phenomena observed. The supposed dry land that disappeared so quickly may have been a raft of floating pumice. Hawaiian pumice in general is so permeable that it floats only a very short time.

The disturbance occurred in a part of the Hawaiian Islands in which there has been no previous recorded historic volcanic activity. It is quite possible, however, that such activity may have occurred. The nearby islands are uninhabited. The area lies away from the regular shipping lanes, and only in recent times has it become frequented by many fishing boats. Eruptions could easily have occurred in that area during the 19th century without being observed by anyone. Even today, with frequent air travel over the area, only one plane chanced to see the August 20 event.

On September 22 planes reported brown and yellow streaks in the ocean and "smoke" rising about 385 miles due west of Honolulu and 205 miles south of Necker Island. The reports made a much less definite picture than those of August 20, and it is rather doubtful that the disturbance was of volcanic origin.

\section{PUBLICATIONS OF THE HAWAIIAN VOLCANO OBSERV.ATORY}

In addition to the annual reports of the Volcano Observatory, published as bulletins of the Geological Survey, reports by staff members on volcanic conditions and features in Hawaii and elsewhere appear in other publications. A report on earthquakes and ground tilting and a summary of volcanic conditions appear quarterly in the Volcano Letter, published by the University of Hawaii. Technical papers appear as lead articles in the Volcano Letter and in various technical journals. The latter form a series known as Contributions of the Hawaiian Volcano Observatory.

Publication of the Volcano Letter was discontinued at the end of 1955 , and henceforth the quarterly report on volcanic and seismic conditions will be published by the Geological Survey and entitled "Hawaiian Volcano Observatory Summary." Those persons wishing to receive the Summary should request. it from the Director of the Geological Survey.

Papers in the Volcano Letter and the Contributions series are listed below. 


\section{VOLCANO LETTER}

Powers, H. A., 1955, A new date in Kilauea's history : no. 527, p. 3.

Macdonald, G. A., 1955, Distribution of areas of pneumatolytic deposition on the floor of Kilauea caldera: no. 528, p. 1-3.

Macdonald, G. A., and Eaton, J.P., 1955, The 1955 eruption of Kilauea volcano: nos. 529 and 530 , p. 1-10.

\section{CONTRIBUTIONS}

Macdonald, G. A., 1955, Volcanoes: Pacific Sci. Cong., 8th Proc. Univ. Philippines, Nov. 16-28, 1953, v. 1, p. 409-412, Quezon.

1955, Hawaiian Islands, pt. 3 of Catalogue of the active volcanoes of of the world, including solfatara fields: Internat. Volcanol. Assoc., Naples, Italy, $37 \mathrm{p}$.

1955, The structure of Hawaiian volcanoes: Koninkl. Nederlandsch Geol.-Mijnb. Genootschap, Verh., Geol. Ser., v. 16, p. 274-295, 1956.

\section{LITERATURE CITED}

Anderson, E. M., 1924, Dynamics of cone-sheets and ring-dykes, in Bailey, E. B., and others, Tertiary and post-Tertiary geology of Mull, Loch Aline, and Oban : Scotland Geol. Survey Mem., p. 11-12.

Daly, R. A., 1911, The nature of volcanic action: Am. Acad. Arts and Sci. Proc., v. 47, p. $48-122$.

Eaton, J. P., 1959, A portable water-tube tiltmeter: Seismol. Soc. America Bull., v. 49 , no. 1, p. 301-316.

Finch, R. H., 1923, Activity by Makaopuhi : Hawaiian Volcano Observatory Bull., v. 11, p. 72, 75 .

1924, Seismic sequences of the explosive eruption of Kilauea in May, 1924: Seismol. Soc. America Bull., v. 14, no. 4, p. 217-222.

Finch, R. H., and Macdonald, G. A., 1951, Report of the Hawaiian Volcano Observatory for 1948 and 1949: U.S. Geol. Survey Bull. 947-D, p. 103-133. 1953, Hawaiian volcanoes during 1950: U.S. Geol. Survey Bull. 996-B, p. $27-89$.

Hagiwara, T., 1948, Observation of changes in the inclination of the earth's surface at Mt. Tsukuba (3d rept.) : Tokyo Univ. Earthquake Research Inst. Bull., v. 25, p. 27-31.

Jaggar, T. A., 1922, Activity of Puna craters: Hawaiian Volcano Observatory Bull., v. 10, p. 47, 54-55.

1924, Subsidence and earthquakes in Puna : Hawaiian Volcano Observatory Bull., v. 12, p. 17-20.

1930, The swelling of volcanoes: Volcano Letter, no. 264, p. 1-3.

1940, Magmatic gases : Am. Jour. Sci., v. 238, no. 5. p. 313-353.

1947, Origin and development of craters: Geol. Soc. America Mem. 21, $508 \mathrm{p}$.

Jones, A. E., 1932, A chart of Kilauea seismicity : Volcano Letter, no. 371, p. 1-3.

Macdonald, G. A., 1941, Lava flows in eastern Puna: Volcano Letter, no. 474, p. 1-3.

1944, The 1840 eruption and crystal differentiation in the Kilauean magma column : Am. Jour. Sci., v. 242, no. 4, p. 177-189.

1949a Hawaiian petrographic province: Geol. Soc. America Bull., v. 60, no. 10, p. 1541-1596. 
1949b, Petrography of. the island of Hawaii : U.S. Geol. Survey Prof.

Paper 214-D, p. 51-96.

1953, Pahoehoe, aa, and block lava : Am. Jour. Sci., v. 251, no. 3, p. 169-191.

1954a, Activity of Hawaiian volcanoes during the years 1940-1950 : Bull. volcanol., ser. 2, v. 15, p. 119-179.

1954b, The Kilauea earthquake of April 22, 1951, and its aftermath:

Volcano Letter, no. 512, p. 1-3.

1955a, Hawaiian volcanoes during 1952 : U.S. Geol. Survey Bull. 1021-B,

p. 15-107.

1955b, Hawaiian Islands, pt. 3 of Catalogue of the active vocanoes of the world including solfatara fields: Internat. Volcanol. Assoc., Naples, Italy, 37 p.

Macdonald, G. A., 1958, Barriers to protect Hilo from lava flows : Pacific Sci., v. 12, no. 3, p. 258-277.

Macdonald, G. A., and Eaiton, J. P., 1954, Hawaiian Volcano Obstrvatory report for October-December, 1954: Volcano Letter, no. 526, p. 4-6.

1955a, The 1955 eruption of Kilauea volcano: Volcano Letter, no. 529-530,

p. 1-10.

1955b, Hawaiian volcanos during 1953 : U.S. Geol. Survey Bull. 1021-D, p. $127-166$.

1957, Hawaiian volcanos during 1954: U.S. Geol. Survey Bull. 1061-B, p. 17-72.

Macdonald, G. A., and Katsura, Takashi, 1961, Variations in the lava of the 1959 eruption in Kilauea Iki : Pacific Sci., v. 15, no. 3, p. 358-369.

Macdonald, G. A., and Orr, J. B., 1950, The 1949 summit eruption of Mauna Loa, Hawaii : U.S. Geol. Survey Bull. 974-A, p. 1-33.

Macdonald, G. A., and Wentworth, C. K., 1954, Hawaiian voleanos during 1951: U.S. Geol. Survey Bull. 996-D, p. 141-216.

Mogi, Kiyoo, 1958, Relations between the eruptions of various volcanos and the deformations of the ground surfaces around them: Tokyo Univ. Earthquake Research Inst: Bull., v. 36, p. 99-134.

Muir, I. D., and Tilley, C. E., 1957, The picrite-basalts of Kilauea, [Pt.] 1 of Contributions to the petrology of Hawaiian basalts: Am. Jour. Sci., v. 255, no. 4, p. 241-253.

Powers, H. A., 1955, Composition and origin of basaltic magma of the Hawaiian Islands: Geochim. et Cosmochim, Acta, v. 7, p. 77-107.

Richter, D. H., and Eaton, J: P., 1960, The 1959-60 eruption of Kilauea Volcano: New Scientist, v. 7, p. 994-997.

Rittmann, Alfred, 1952, Nomenclature of volcanic rocks: Bull. volcanol., ser. 2, v. 12, p. 75-102.

Rubin, Meyer, and Alexander, Corrinne, 1958, U.S. Geological Survey radiocarbon dates, [Pt.] 4 : Science, v. 127, p. 1476-1487.

Stearns, H. T., and Clark, W. O., 1930, Geology and water resources of the Kan District, Hawaii : U.S. Geol. Survey. Water-Supply Paper 616, 194 p.

Stearns; H. T., and Macdonald, G. A., 1942, Geology and ground-water resources of the island of Maui, Hawaii : Hawaii Div. Hydrography Bull. 7, 344 p. 1946; Geology. and ground-water resources of the island of Hawaii: Hawaii Div. Hydrography Bull. 9, 363 p.

Tilley, C. E., 1960, Differentiation of Hawaiian basalts-some variants in lava suites of dated Kilauean eruptions: Jour. Petrology, v. 1, p. 47-55. 
Wentworth, C. K., and Macdonald, G. A., 1953, Structures and forms of basaltic rocks in Hawaii : U.S. Geol. Survey Bull. 994, 98 p.

Williams, Howel, 1950, Volcanoes of the Paricutin region, Mexico: U.S. Geol. Survey Bull. 965-B, p. 165-279.

Wilson, R. M., 1935, Ground surface movements at Kilauea volcano, Hawaii : Hawaii Univ., Research Pub. 10, $56 \mathrm{p}$.

Yoder, H. S., Jr., and Tilley, C. E., 1957, Basalt magmas : Carnegie Inst. Washington, Geophys. Lab., Ann. Rept. for 1956-1957, p. 156-161. 



\section{INDEX}

[Italic page numbers indicate major references]

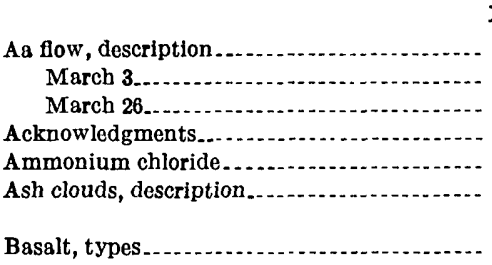

Bench marks, changes in elevation

$105,111,118$

Blowhole vent

Bosch-Omori seismograph. See Seismographs.

Cape Kumukahi

Centripetal tilting

Chain of Craters

Chemical analyses of lavas

Cinder, cones eruption

Crack measurements

Crustal structure

Devil's Throat

Dikes.

Disappearing-dot pyrometer

Diversion of flows

Earthquakes, distant

east rift zone series.

Kalalua swarm.

(22, 12

Kilauea summit series................... 118,120

March 27, Kilauea calder a area............

March and April 1924.

number recorded at Pahoa..................

preceding eruption in East Puns

preceding third phase of eruption........ 28, 119

statistics.

summary

treatment of data

East Puna, earthquakes in

eruption in, events following

events preceding.

final phase

first phase.

losses caused by.

mechanism of

quiet period

second phase

structural and historical setting........

summary.

third phase

ground movements in
Page

f 1955 . See East Puna, eruption in

Eruptive fissures, pattern.................. 103, 121

Fault scarps, formation of .............. 20, 101, 105

soutb of rift-zone arch...................... 6

8 Focal depths................................ 118

Fumaroles, temperatures in ............... 50,84

87

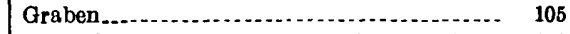

Ground movements accompanying eruption.- 101

Haleakala, eruption, 1750

Halekamahina hill......................... 22

Halemaumau crater..................... 3,6,8

Harmonic tremor .......... . . . . . . . . . 113, 125

Hawaii National Park........................ 13

Heiheiahulu cone............................. 7

Hillina fault................. 118

Inclusions in lavas........................... 86

Introduction............................. 2

Iwasaki Camp............................. 14, 73, 78

Kalalua earthquake swarm ................. 122, 124

Kalapana, earthquakes at.................. 129

Kamaili, evacuation of....................... $\quad 29$

Kamaili area, buried fault scarps............. 6

Kaoiki fault ................................ 118, 161

Kapoho, evacuation of................... 18, 20, 26

Kaueleau area, buried fault scarps........... 6

Kaueleau flow ............................. 40

Keekee flow ................................. 54

Kehena flow .............................. 58,66

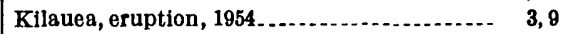

eruption, 1954, chemical variation of lava. $\quad 90$

historic flank eruptions.................... 6

leveling at c8ldera ...................... 111

sinking in summit region ................ 108, 118

temperature measurements at caldera..... 154

Koae, frequency of earthquakes at............ 16

Lava, chemical analyses..................... 87, 154

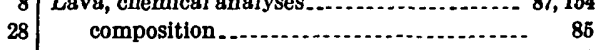

101 variation....................... 
Lav8,-Continued

Pago

flows, cascade.

$70,77,78$ entrance into ocean

effect on composition

$70,72,77$

high speed

temperatures..................... 81, 88,95

thickness............................. 83

types.

See also Aa; Pahoehoe; particular named flows.

flow of 1954

fountains, characteristics

early development

height.

temperature readings

historic flows.......................... 6

prehistoric, ages.......................... 156

subsidence of in Halemaumau crater.......

viscosity, measurement of..................

volume and rate of extrusion............... 83

Leeds and Northrup pyrometer ........... 37, 69, 82

Leveling at Kilauea caldera.....................- 111

Literature cited. .............................. 165

Loucks-Omori seismograph. See Seismographs.

Malams Crack

Maui, island of.

Mauna Loa, analyses of lavas

quiescence.

Mineralogy of lavas.

Mohorovicic discontinuity

Namba's hill.

Nanawale Ranch, earthquakes felt at

Necker Island, possible eruption near.

Olivine

Optical pyrometer readings.....................-

Oxides, changes in proportions throughout eruption.

Pahala ash.

Pahoa seismograph, record of east rift zone earthquakes

record of volcanic tremor................... 16,68

station, tilting at.

102,104

Pahoehoe flow, April 24...................... 14

April 27...................................... 62,82

experimental diversion of................ 31

March 2.................................... 21, 88

Paricutin

Pele's tears, hair........................... 46, 81, 90

Pendulums.................................... 101

Penetrometer, for measuring lava viscosity....

Pyr

65

stro

Page

Phenocrysts................................... 85

Phreatomagmatic eruption.................... 24

Pit craters, formation of ................... 13, 45, 98

Pumice............................................ 47,81

Puna District, location....................... 3

See also Easț Puna.

Puu Honuauls.............. 16

Pyrometers, types used......................... 92

Pyroxene...................................... 91

Radiocarbon age determinations............... 157

Rainfall records . . . . .

Rift zones.... 6 See also East rift zone.

Seismicity, weekly .......................... 144

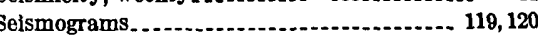

Seismographs, Bosch-Omori............. 128, 143, 157

location of stations

Loucks-Omori................... 113, 122, 124, 158

Sprengnether............................... 125

Seismographs and tiltmeters...................... 140

Spatter cones................................ 39, 76,81

Steam, discharge............................ 19,44, 5s

Strain-release index

Stromboli.

Sublimates...................................... 92

Subsidence of Kilaues caldera................ 108, 118

Sulfur, deposited as sublimate

Summary of Volcano Observatory for 1955.... 140

Temperature measurements of lava............ 92

Thermocouple................................. 95

Tilting of ground surface, measurement of.. 101,151

Tiltmeter, installation at Whitney Laboratory

Traveltime curves.............................. 133

Uwekahuna laccolith........................... 90

Variation diagram of major oxides.............. 88

Vegetation, reoccupation of eruption area..... 132

Vents of 1955 eruption, location.............. 30, 50 opening of

Viscosity of lava........... 96

Volcano Observatory, location................. 7

publications of ......................... 164

summary for $1955 \ldots$

Whitney Laboratory of Seismology, new equipment ......................... 3

tilting measured at $\ldots \ldots \ldots \ldots \ldots \ldots \ldots$ 108,114,129

96 Wood-Anderson seismograph record........ 120, 123 